UNIVERSIDADE DE SÃO PAULO

FACULDADE DE FILOSOFIA, LETRAS E CIÊNCIAS HUMANAS PROGRAMA DE PÓS-GRADUAÇÃO EM LÍNGUA ESPANHOLA E LITERATURAS ESPANHOLA E HISPANO-AMERICANA

ROSÂNGELA APARECIDA DANTAS DE OLIVEIRA

\title{
O que cabe entre essas quatro retas? \\ Análise discursiva de tiras cômicas argentinas e brasileiras sobre as Copas de 1994 e 2014
}

São Paulo

2017

Versão corrigida 
ROSÂNGELA APARECIDA DANTAS DE OLIVEIRA

\section{O que cabe entre essas quatro retas? Análise discursiva de tiras cômicas argentinas e brasileiras sobre as Copas de 1994 e 2014}

Tese de doutorado apresentada ao Programa de PósGraduação em Língua Espanhola e Literaturas Espanhola e Hispano-Americana da Faculdade de Filosofia, Letras e Ciências Humanas da Universidade de São Paulo.

Orientadora: Profa. Dra. Maria Zulma Moriondo Kulikowski

São Paulo 
Autorizo a reprodução e divulgação total ou parcial deste trabalho por qualquer meio convencional ou eletrônico, para fins de estudo e pesquisa, desde que citada a fonte.

Catalogação na Publicação

Serviço de Biblioteca e Documentação

Faculdade de Filosofia, Letras e Ciências Humanas da Universidade de São Paulo

Oliveira, Rosângela Aparecida Dantas de Oliveira

0 que cabe entre essas quatro retas? Análise discursiva de tiras cômicas argentinas e brasileiras sobre as Copas de 1994 e 2014 / Rosângela Aparecida Dantas de Oliveira Oliveira ; orientador María Zulma Moriondo Kulikowski Kulikowski. - São Paulo, 2017. $273 \mathrm{f}$

Tese (Doutorado) - Faculdade de Filosofia, Letras e Ciências Humanas da Universidade de São Paulo. Departamento de Letras Modernas. Área de concentração: Língua Espanhola e Literaturas Espanhola e Hispano-Americana.

1. Tiras cômicas. 2. Estudos comparados Brasil Argentina. 3. Futebol. 4. Humor . 5. Cena da enunciação. I. Kulikowski, María Zulma Moriondo Kulikowski, orient. II. Título. 


\section{FOLHA DE APROVAÇÃO}

Nome: OLIVEIRA, Rosângela Aparecida Dantas de

Título: O que cabe entre essas quatro retas? Análise discursiva de tiras cômicas argentinas e brasileiras sobre as Copas de 1994 e 2014

Tese de doutorado apresentada ao Programa de PósGraduação em Língua Espanhola e Literaturas Espanhola e Hispano-Americana da Faculdade de Filosofia, Letras e Ciências Humanas da Universidade de São Paulo.

Aprovada em: 29/09/2017

Banca examinadora

Profa. Dra. María Zulma Moriondo Kulikowski

Julgamento: Aprovada

Profa. Dra. Luciana Salazar Salgado

Julgamento: Aprovada

Prof. Dr. Paulo Eduardo Ramos

Julgamento: Aprovada

Prof. Dr. Flávio Campos

Julgamento: Aprovada

Prof. Dr. Adrián Fanjul

Julgamento: Aprovada
Instituição: USP

Assinatura:

Instituição: UFSCAR

Assinatura:

Instituição: UNIFESP

Assinatura:

Instituição: USP

Assinatura:

Instituição: USP

Assinatura: 


\section{DEDICATÓRIA}

A meu amado pai, João Dantas de Oliveira (in memorian), cuja voz gritando gol é das lembranças mais cálidas que guardo em minha memória; e à minha amada mãe, Naylde Soutto Dantas, por terem comprado livros a prestação em nossa infância e por terem me permitido voar.

Aos santistas da minha vida: Franklin, Rodrigo e Fernando.

Às mulheres que habitam minha história. 


\section{AGRADECIMENTOS}

À querida Profa. Dra. Maria Zulma Moriondo Kulikowski, pelos anos de orientação, por me ajudar a crescer, por sua generosidade, compreensão e paciência infinitas com meu jeito anárquico e intuitivo de fazer pesquisa.

Aos Profs. Drs. Adrián Fanjul e Paulo Ramos, pela leitura atenta, pelos comentários, críticas e sugestões na qualificação e na defesa, pela presteza e pelo afeto com que sempre me atenderam em meus pedidos de ajuda e pela generosidade em compartilhar conhecimento e bibliografia.

Aos demais membros da banca, Profa. Dra. Luciana Salazar Salgado e Prof. Dr. Flávio de Campos, pela leitura criteriosa, pelos apontamentos efetuados durante a defesa e por suas contribuições para a versão corrigida deste trabalho.

Ao Franklin, com quem escrevo uma linda história de amor há quase 30 anos, por tanta, tanta coisa que nem caberia nesta tese.

À minha família, a de sangue e a herdada pelo casamento, pela torcida e pela colaboração ponta firme nos momentos finais.

Ao colectivo de espanhol da Unifesp: Andreia, Etel, Graciela, Greice, Joana, Ivan e Neide, pelo apoio, pelas ajudas, pela contenção nos momentos de desesperança e por serem amor y revolución.

Às (ex-)alunas e aos (ex-)alunos da Unifesp, que só conviveram comigo em estado de doutorado e afetuosamente entenderam minhas lacunas e torceram por mim.

À Francisca Maria Pinheiro Costa, nossa funcionária, por ter aberto mão de suas férias para me ajudar na reta final.

Às amigas Cida Gazotti Vallim, Mônica Mayrink, Fernanda Soave Pagliuso, Andrea Pizzutiello e Enrique Melone pelo auxílio com as línguas estrangeiras.

Aos amigos Laura Sokolowicz e Martín Russo pelo empréstimo de livros sine die, pelas conversas e pelas ajudas.

E a todas as amigas e amigos que acompanharam - de longe ou de perto - esta empreitada, que torceram por mim e que estiveram sempre disposta(o)s a me ajudar. 
Un vacío asombroso: la historia oficial ignora al fútbol. Los textos de historia contemporánea no lo mencionan, ni de paso, en países donde el fútbol ha sido y sigue siendo un signo primordial de identidad colectiva. Juego, luego soy: el estilo de jugar es un modo de ser, que revela el perfil propio de cada comunidad y afirma su derecho a la diferencia. Dime cómo juegas y te diré quién eres: Hace ya muchos años que se juega al fútbol de diversas maneras, expresiones diversas de la personalidad de cada pueblo, y el rescate de esa diversidad me parece, hoy día, más necesario que nunca. Estos son tiempos de uniformización obligatoria, en el fútbol y en todo lo demás. Nunca el mundo ha sido tan desigual en las oportunidades que ofrece y tan igualador en las costumbres que impone: en este mundo de fin de siglo, quien no muere de hambre, muere de aburrimiento.

(In: GALEANO, Eduardo. El fútbol a sol y sombra, 1999, p. 243-4.) 


\section{RESUMO}

OLIVEIRA, R. A. D. O que cabe entre essas quatro retas? Análise discursiva de tiras cômicas argentinas e brasileiras sobre as Copas de 1994 e 2014. 2017. $267 \mathrm{f}$. Tese (Doutorado) - Programa de Pós-Graduação em Língua Espanhola e Literaturas Espanhola e Hispano-Americana, Faculdade de Filosofia, Letras e Ciências Humanas, Universidade de São Paulo, São Paulo, 2017.

Esta tese apresenta os resultados de uma pesquisa sobre tiras cômicas de produção local na Argentina e no Brasil, tendo como recorte temático o futebol e seu papel na construção identitária de ambos os países. Abordamos as tiras cômicas como um gênero discursivo, ou seja, como um dispositivo comunicacional sócio-historicamente condicionado (Maingueneau, 2010) e as analisamos levando em conta sua inserção na espacialidade social. Trata-se de um trabalho comparativo e interdisciplinar em que nos valemos de referenciais teóricos tanto dos estudos discursivos e enunciativos, como também de reflexões advindas de outros campos do conhecimento, como a História (Campos, 2015; Franco-Júnior, 2007), a Sociologia (Bordieu ([1976]-2002; Archetti, 1995; Alabarces, 2014), a Antropologia (Guedes, 2006) e a Comunicação (Martín-Barbero, 1991). Para operacionalizar a análise, mobilizamos o conceito de cena da enunciação (Maingueneau, 2001, 2006). No exame da cena englobante e da cena genérica das tiras cômicas, reconstruímos sua historicidade na Argentina e no Brasil, enfocando especificamente sua publicação rotineira nos jornais diários. Nesse percurso, constatamos que diferenças verificadas na formação sócio-histórica desses países repercutem na inserção do gênero na respectiva espacialidade social. Para a análise das cenografias, nos debruçamos sobre um corpus composto por tiras argentinas e brasileiras publicadas respectivamente nos jornais Clarín e Folha de S. Paulo por ocasião das Copas do Mundo de 1994 e 2014. Baseando-nos também nas categorias propostas por Charaudeau (2006) para o estudo do discurso humorístico, na análise dessas tiras (i) investigamos que efeitos de sentido são construídos sobre as derrotas e as vitórias das seleções argentina e brasileira nas citadas edições da Copa; (ii) examinamos os procedimentos utilizados para obter o humor e seus possíveis efeitos, (iii) observamos que relações interdiscursivas se estabelecem, (iv) identificamos posicionamentos a respeito do futebol e da Copa. Contrastados os resultados, relevamos as semelhanças e diferenças com relação aos temas anteriores observadas nas produções de ambos os países.

Palavras-chave: tiras cômicas, estudos comparados, Argentina, Brasil, futebol, cena da enunciação, humor. 


\begin{abstract}
OLIVEIRA, R. A. D. What can we fit into these four lines? A discursive analysis of Argentinian and Brazilian comic strips about the 1994 and 2014 World Cups. 2017. 267 f. Thesis (Doctoral) - Programa de Pós-Graduação em Língua Espanhola e Literaturas Espanhola e Hispano-Americana, Faculdade de Filosofia, Letras e Ciências Humanas, Universidade de São Paulo, São Paulo, 2017.
\end{abstract}

This thesis shows the results of a research on comics strips from local production in Argentine and in Brazil, focus on football and its role in the identity construction of both countries. Approaching the comic strips as a discursive genre, that is, as a sociohistorically conditioned communicational device (Maingueneau, 2010) and analyzing them considering their insertion in the social spatiality. It is a comparative and interdisciplinary work in which we use theoretical references from both the discursive and enunciative studies, as well as reflections from other fields of knowledge, such as History (Campos, 2015; Franco-Júnior, 2007). Sociology (Bordieu ([1976] -2002, Archetti, 1995, Alabarces, 2014), Anthropology (Guedes, 2006) and Communication (Martín-Barbero, 1991). In order to analyze, we mobilized the concept of the scene of enunciation (Maingueneau, 2001, 2006). From the exam of the encompassing and generic scene of the comic strips, we reconstructed its historicity in Argentina and Brazil, focusing specifically on its routine publication in the daily newspapers. Along the way, we found that the differences identified in the socio-historical formation of these countries rebound in the insertion of the gender in the respective social spatiality. Analyzing the scenographies, we considered a corpus composed of Argentine and Brazilian strips published respectively in the Clarín and Folha de S. Paulo newspapers by the 1994 and 2014 World Cup occasions. Based on the categories proposed by Charaudeau (2006) for the study of humorous discourse, in the analysis of these strips (i) we investigated what kind of meaning effects are built on the defeats and victories of the Argentine and Brazilian teams in the aforementioned editions of the Cup; (Ii) we examined the procedures used to obtain the humor and its possible effects, (iii) we observed that the interdiscursive relationships are established, (iv) identified positions regarding to soccer and the World Cup. Contrasting the results, we highlighted the similarities and differences in relation to the previous themes observed in the productions of both countries.

Key words: comic strips, comparative studies, Argentina, Brazil, football, enunciation scene, humor. 


\section{RESUMEN}

OLIVEIRA, R. A. D. ¿Qué cabe entre esas cuatro rectas? Un análisis discursivo de tiras cómicas argentinas y brasileñas sobre los Mundiales de 1994 y 2014. 2017. 267 f. Tesis (Doctorado) - Programa de Pós-Graduação em Língua Espanhola e Literaturas Espanhola e Hispano-Americana, Faculdade de Filosofia, Letras e Ciências Humanas, Universidade de São Paulo, São Paulo, 2017.

En esta tesis se presentan los resultados de una investigación sobre tiras cómicas producidas en Argentina y en Brasil. El recorte temático es el fútbol y su papel en la construcción de la identidad de ambos países. Entendemos las tiras cómicas como un género discursivo, o sea, como un dispositivo comunicacional sociohistóricamente condicionado (Maingueneau, 2010) y las analizamos teniendo en cuenta su inserción en la espacialidad social. Se trata de un trabajo comparativo e interdisciplinario para el cual buscamos bases teóricas tanto en los estudios discursivos y enunciativos, como en las reflexiones oriundas de otros campos de conocimiento, como el de la Historia (Campos, 2015; Franco-Júnior, 2007), el de la Sociología (Bordieu ([1976]-2002; Archetti, 1995; Alabarces, 2014), el de la Antropología (Guedes, 2006) y el de la Comunicación (MartínBarbero, 1991). Para llevar a cabo el análisis, usamos movilizamos el concepto de escena de la enunciación (Maingueneau, 2001, 2006). En el examen de la escena englobante y de la escena genérica de las tiras cómicas, reconstruimos su historicidad en Argentina y en Brasil enfocando específicamente su publicación diaria en los periódicos. En ese proceso, constatamos que diferencias en la formación sociohistórica de esos países repercuten en la inserción del género en la respectiva espacialidad social. Para el análisis de las escenografías, trabajamos con un corpus de tiras publicadas en los diarios Clarín, de Argentina, y Folha de S. Paulo, de Brasil, durante los Mundiales de Fútbol de 1994 y 2014. Basándonos también en las categorías propuestas por Charaudeau (2006) para el estudio del discurso humorístico, en el análisis de dichas tiras (i) investigamos qué efectos de sentido se construyen sobre las derrotas y las victorias de las selecciones argentina y brasileña en las mencionadas ediciones de los Mundiales; (ii) examinamos los procedimientos utilizados para lograr el efecto de humor y sus posibles efectos, (iii) observamos qué relaciones interdiscursivas se establecen, (iv) identificamos posicionamientos respecto al fútbol y los Mundiales. Contrastados los resultados, apuntamos las semejanzas y diferencias que se observaron respecto a los temas anteriores en las producciones de ambos países.

Palabras-clave: tiras cómicas, estudios comparados, Argentina, Brasil, fútbol, escena de la enunciación, humor. 


\section{SUMÁRIO}

INTRODUÇÃ̃O

PARTE 1 - ARCABOUÇO TEÓRICO E CONCEITUAL

CAPÍTULO 1 : Aportes dos estudos discursivos

0. Introdução

1. Sobre o conceito de gênero

1.1 Antecedentes

1.2 A reconceituação a partir do Círculo de Bakhtin

2. Gêneros discursivos e espacialidade social

2.1 Campo social

$2.2 \mathrm{O}$ humor como campo discursivo

3. A cena da enunciação

4. Estereótipo e memória

5. A noção de ethos

6. Particitação e hiperenunciador

6.1 O slogan militante

6.2 Os cantos de torcida

CAPÍTULO 2 - Sobre o humor

0. Introdução

1. Uma sociedade humorística?

2. As teorias sobre o humor 
3.2 Uma relação triádica $\quad 58$

3.3 Os procedimentos linguageiros para o humor e seus possíveis efeitos 61

$\begin{array}{ll}\text { 3.3.1 Os procedimentos discursivos } & 62\end{array}$

3.3.1.1 O jogo enunciativo irônico $\quad 62$

3.3.1.2 O jogo enunciativo sarcástico $\quad 62$

$\begin{array}{ll}\text { 3.3.1.3 O jogo enunciativo paródico } & 63\end{array}$

3.3.2 Os procedimentos lógico-semânticos $\quad 63$

3.3.2.1 A incoerência louca $\quad 63$

3.3.2.2 A incoerência insólita $\quad 64$

3.3.2.3 A incoerência paradoxal $\quad 65$

$\begin{array}{ll}\text { 3.3.3 Os efeitos possíveis } & 65\end{array}$

3.3.3.1 A conivência lúdica 66

3.3.3.2 A conivência crítica $\quad 66$

3.3.3.3 A conivência cínica $\quad 66$

3.3.3.4 A conivência de derrisão 66

$\begin{array}{ll}\text { 4. Humor e tiras cômicas } & 67\end{array}$

$\begin{array}{ll}\text { 5. Nosso posicionamento } & 68\end{array}$

CAPÍTULO 3 - Futebol e identidades nacionais na Argentina e no Brasil 70

$\begin{array}{ll}\text { 0. Introdução } & 70\end{array}$

1. Aproximação ao conceito de identidade $\quad 70$

2. O futebol na Argentina e no Brasil $\quad 72$

3. Copa do Mundo e identidades nacionais $\quad 78$ 
PARTE 2 - SOBRE TIRAS CÔMICAS, JORNAIS, VITÓRIAS E

\section{DERROTAS}

CAPÍTULO 4 - O quadro cênico

1. Tiras cômicas em jornais diários: uma cena genérica, duas cenas englobantes

2. Aspectos formais do gênero tiras cômicas

3. Marcos históricos das tiras cômicas

3.1 As origens

3.2 As tiras cômicas na Argentina durante o século XX

3.2.1 A página de humor do Clarín

3.3 As tiras cômicas no Brasil durante o século XX

3.3.1 A página de quadrinhos da Folha de S. Paulo

CAPÍTULO 5 - As Copas de 1994 e de 2014 nas páginas

do Clarín e da Folha de S. Paulo

0. Introdução

1. O caso da Copa de 1994

1.1 Aspectos gerais 
1.3.1 A seleção brasileira, a Copa de 1994 e as tiras da Folha de S. Paulo

1.3.2 Um olhar argentino sobre o tetracampeonato

2. O caso da Copa de 2014

2.1 Aspectos gerais

2.1.1 Antecedentes

2.1.2 O período de junho de 2013 a julho de 2014

2.2 Embates nas ruas, embates nas tiras

2.2.1 O pintinho - Esporte nacional

2.2.2 Chico Bacon - Não vai ter Copa e Estádio lindo

2.2.3 A modo de retomada

2.3 O Brasil na Copa de 2014

2.3.1 A seleção brasileira, a Copa de 2014 e as tiras da Folha de S. Paulo

2.3.1.1 Chico Bacon - Soterrado

2.3.1.2. Malvados - Realidade, não

2.3.1.3 Depryzinha - Motivos para deprimir-se

2.3.1.4 O pintinho - Prova-surpresa 
2.4.1.4 Donatela - Hinchada histórica

2.4.1.5.Donatela - Bienvenidos héroes

2.4.1.6 Yo, Matías - Vicecampeones

2.4.1.7 La Nelly - Que bajón

2.4.1.8 A modo de retomada

3 Discussão comparativa dos resultados

3.1 Sobre o humor

3.1.1 Os procedimentos

3.1.2 Os efeitos possíveis

3.2 Sobre as cenografias

3.2.2 O leitor explicitamente convocado

3.2.3 "Nosotros" e "o Brasil"

3.2.4 Particitações e hiperenunciadores

3.3 Sobre futebol, Copa do Mundo, brasileiros e argentinos

3.3.1 A Copa como suspensão do tempo 
Anexo 1 - Letra da canção Yo no quiero volverme tan loco de Charly García

Anexo 3 - Produções gráficas publicadas nos jornais Clarín e La Nación em $14 / 07 / 2014$ 



\section{INTRODUÇÃO}

Este trabalho vem na esteira de vários estudos comparados desenvolvidos no âmbito do Programa de Pós-graduação em Língua Espanhola e Literaturas Espanhola e Latino-Americana tais como Lima (2012), Menezes (2012), Russo (2013), Menón (2015) entre outros ${ }^{1}$. Com alguns desses trabalhos compartilha também o fato de ter como objeto de estudo um gênero da cultura de massa, somando-se assim a investigações que vêm incorporando esses produtos à reflexão acadêmica. Ocupamo-nos especificamente de tiras cômicas $^{2}$ publicadas durante a realização de algumas edições da Copa do Mundo. O recorte efetuado para investigar nosso objeto de estudo incorpora, portanto, mais um fenômeno popular, o futebol. Nossa pesquisa se insere dessa forma em áreas que vêm experimentando um crescimento significativo: quadrinhos e futebol como objetos de investigação acadêmica, e os estudos comparados. Como tal se constitui em um trabalho interdisciplinar em que mobilizamos conhecimentos da área dos estudos discursivos (Bakhtin, Maingueneau, Charaudeau), de onde ela se origina, bem como da História (Franco-Júnior, 2007; Campos, 2015), da Sociologia (Bordieu, 2002; Archetti, 1995; Alabarces, 2014), da Antropologia (Guedes, 2006) e da Comunicação (Martín-Barbero, 1991).

A motivação para o desenvolvimento do projeto do qual resultou esta tese veio de inquietações surgidas de ao menos duas das dimensões que compõem nossa identidade: a experiência profissional e a das indagações pessoais sobre nossa condição de brasileira e o que isso significa.

No profissional, como professora e pesquisadora de uma língua estrangeira, trabalhamos sempre com culturas em contato, a nossa e as que nos são alheias, e é necessário não só conhecê-las mais profundamente como também estabelecer pontes para que os aprendizes o façam. Em nossa prática docente, as tiras cômicas - por seu aspecto humorístico, pela presença de marcas da oralidade, pela simulação de diálogos cotidianos, entre outras características - sempre estiveram presentes. E ao mesmo tempo que nos proporcionaram ricos conteúdos a serem explorados em sala aula, compreendê-las, por outro lado, muitas vezes representou para nós mesmas um desafio a ser superado. Justamente por envolver o humor, percebemos que se tratava de um rico material para

\footnotetext{
${ }^{1}$ Para informações mais detalhadas a respeito de estudos comparados entre português brasileiro e espanhol remetemos a Fanjul e González (2014).

${ }^{2}$ Neste trabalho adotamos tira cômica ou tira para referir-nos ao gênero que é nosso objeto de estudo. Há uma grande oscilação em sua nomenclatura, já documentada por Ramos (2013).
} 
investigar estereótipos, ideologias e tensões da cultura em que foram produzidas, algo já apontado por Possenti (2010, 2008) em seus trabalhos a respeito do humor. Em nossa prática, também constatamos a alta qualidade e relevância da produção argentina de quadrinhos em geral, como apontado por Martignone \& Prunes (2008), Gociol \& Gutiérrez (2000 e 2012) entre vários outros da farta produção bibliográfica sobre esse tema na Argentina. A produção brasileira, por seu turno, também é relevante e vem recebendo cada vez mais atenção por parte de especialistas como já documentado por Ramos (2006), Vergueiro (2005) e Vergueiro \& Santos (2006).

Nosso projeto de doutorado, portanto, envolvia um trabalho comparativo entre tiras cômicas brasileiras e argentinas. O recorte temático do trabalho responde à dimensão das indagações sobre identidade. Pensando na contribuição que podemos dar aos possíveis pesquisadores em formação que venham a ler este trabalho, devemos reconhecer que foi o procedimento que mais dificuldades nos causou e que mais demorou a se definir. Questões de imagem e identidade já haviam sido nosso objeto de pesquisa no mestrado e era nosso desejo continuar nos aprofundando a esse respeito, portanto estavam presentes no projeto desde o início. Porém era necessário ajustar o foco para selecionar um fragmento no enorme universo de informações que o tema representa. Os preparativos para Copa realizada no Brasil nos proporcionaram a resposta: abordaríamos o futebol, que igualmente tem recebido cada vez mais atenção como objeto a ser estudado, como podemos constatar, por exemplo, em Gastaldo \& Guedes (2006), Campos \& Alfonsi (2014) e Marques (2015).

Assim, nosso trabalho se configura como uma análise discursiva, enunciativa e comparativa sobre tiras cômicas argentinas e brasileiras publicadas nos jornais Folha de $S$ Paulo e Clarín durante as Copas do Mundo de 1994 e 2014. A escolha dos jornais se deve ao papel que desempenharam na consolidação do gênero tiras cômicas nos dois países (cf. MARTIGNONE \& PRUNES, 2008). Não obstante o já citado crescimento de pesquisas acadêmicas nas áreas com que trabalhamos, desconhecemos investigações no âmbito dos estudos discursivos que aliem esses mesmos temas, a saber, tiras cômicas, futebol, Brasil e Argentina. Assim, nosso trabalho além de contribuir com o campo das pesquisas realizadas sobre esses temas, visa também começar a preencher uma lacuna e iluminar novas faces das tiras cômicas como objeto de estudo.

Para o desenvolvimento desta pesquisa, partimos de alguns pressupostos. Primeiramente que o futebol tem um papel fundamental na construção identitária da 
Argentina e do Brasil e que, nesse sentido, os eventos da Copa do Mundo constituem momentos privilegiados para investigar essa relação.

Ademais entendemos, tal como Martignone e Prunes (2008, p. 41) e Magalhães (2006: 10) que as tiras cômicas argentinas e brasileiras de produção local são fortemente ligadas à realidade cotidiana e às idiossincrasias dos habitantes desses países, em especial quando as tomamos a partir de sua publicação em jornais diários. Essa ligação é estabelecida pelo discurso, que se realiza na forma de um gênero discursivo, um dispositivo comunicacional sócio-historicamente condicionado (MAINGUENEAU, 2010).

Com base na leitura de Mendonça (2010) e Ramos (2011a), vemos as tiras cômicas como um gênero discursivo que mescla duas semioses - uma verbal e uma não verbal - com um desfecho que provoca efeito humorístico, cujas coerções do formato exigem operações complexas na construção do sentido (capacidade de síntese por parte do autor e recuperação de vários tipos de informações explícitas e implícitas por parte do leitor, entre outras). Entendemos também, conforme Brait (1996, p. 15), que a natureza significante do humor muitas vezes se constrói com base no deslindamento de valores sociais, culturais e morais de uma dada cultura ou sociedade.

Isto posto, os objetivos principais de nossa pesquisa foram investigar as tiras cômicas entendidas como gêneros discursivos para verificar que efeitos de sentido são construídos sobre as derrotas e as vitórias das seleções argentina e brasileira nas edições da Copa de 1994 e 2014; analisar os procedimentos utilizados para obter o humor e seus possíveis efeitos, observar que relações seus discursos estabelecem com outros discursos da imprensa sobre o futebol ou a Copa nos respectivos países, verificar os posicionamentos que a respeito desses temas se revelam, analisar as semelhanças e diferenças com relação aos pontos anteriores nas produções de ambos os países.

\section{Aspectos metodológicos e descrição do corpus}

Nosso propósito inicial de doutorado era realizar um estudo diacrônico que compreenderia as produções publicadas durante as Copas do Mundo de 1994 até 2014, ou seja, durante seis edições do campeonato, e que tivessem por tema a participação dos dois países nesses eventos. O desenvolvimento da pesquisa, no entanto, nos mostrou que o tipo de análise que pretendíamos realizar era incompatível com o volume de tiras que o intervalo implicava e com o tempo de que dispúnhamos para a conclusão do doutorado. 
Assim, reformulamos nosso projeto quanto ao período e decidimos examinar as tiras publicadas durante a Copa de 1994 e de 2014. Essas edições foram escolhidas porque no período estudado ambas as seleções tiveram nelas tanto os seus melhores como os piores resultados.

Em 1994, o Brasil sagrou-se tetracampeão após 24 anos sem títulos significativos, excetuando-se um quarto lugar em 1974 e um terceiro em 1978. A Argentina, por sua vez, viveu um dos episódios mais traumáticos em sua história futebolística: a suspensão de Maradona por dopping e a eliminação da seleção nas oitavas de final.

Quanto à Copa de 2014, por ter se realizado no Brasil e em um contexto de profundas mudanças políticas e sociais, seus dados são muito representativos para o nosso corpus. Ademais, embora nenhuma das seleções dos países que estudamos tenha se sagrado campeã em 2014, a Argentina conquistou um vice-campeonato, seu melhor resultado no período que estudamos. Já o Brasil sofreu uma derrota histórica, perdeu de 7 a 1 para a Alemanha, numa partida que possivelmente será lembrada como o pior desempenho da seleção. Assim, entendemos que tomando a Copa de 1994 e a de 2014, conseguimos trabalhar com duas situações cujos resultados podem ser considerados espelhados, mas ao contrário.

O conjunto de tiras analisado no capítulo cinco da tese, portanto, faz parte de um corpus extraído das páginas dos jornais Clarín, editado na cidade de Buenos Aires Argentina -, e Folha de S. Paulo, editado na mesma cidade brasileira que lhe dá título. A Copa de 1994 se realizou nos Estados Unidos de 17 de junho a 17 de julho de 1994 e a de 2014, no Brasil, entre 12 de junho a 13 de julho de 2014.

O principal critério na escolha dos veículos foi, como já afirmamos, a representatividade de ambos para a historicidade do campo do humor gráfico e das tiras cômicas em cada um dos países. Além disso, ambos os jornais se assemelham quanto a seu posicionamento no mercado, em comparação com os outros diários existentes nos países, e quanto ao perfil dos leitores. Assim, acreditamos que pudemos trabalhar com características análogas em nosso estudo, ressaltando que não tratamos, em absoluto, de considerar ou perseguir condições idênticas para ambos, objetivo que seria impossível justamente pelo campo do conhecimento com que trabalhamos.

As tiras foram extraídas dos cadernos em que são publicadas normalmente em cada um dos jornais. Optamos por não tomar como objeto de análise as tiras eventualmente publicadas nos cadernos ou seções especiais criados pelos jornais para o evento da Copa do Mundo, pois, justamente por serem cadernos temáticos, todos os 
gêneros neles encontrados referem-se ao campeonato. Assim, os quadrinistas sabem antecipadamente que deverão abordar a Copa em suas produções e um de nossos objetivos é justamente investigar o impacto dos eventos do campeonato nas tiras cômicas, ou seja, fixar nosso olhar na articulação entre os temas abordados cotidianamente nas tiras e os acontecimentos do contexto sócio-histórico. Além disso, publicações temáticas pressupõem um leitor com um tipo de interesse específico e, por conseguinte, conhecimentos específicos, característica que nos pareceu que também se chocava com nosso propósito.

As tiras publicadas na Folha de S. Paulo que compõem o corpus foram integralmente extraídas das versões fac-similares que se encontram no Acervo Folha, um portal que abriga as edições da Folha de S. Paulo, Folha da Manhã e Folha da Noite desde 1921 e disponível na internet ${ }^{3}$ mediante assinatura.

Diferentemente da Folha de S. Paulo, o jornal Clarín não conta com praticamente todas as suas edições digitalizadas. No site da versão eletrônica do jornal ${ }^{4}$, disponível também mediante assinatura, encontramos edições fac-similares às publicadas em papel a partir de 25 de outubro de 2003, portanto só extraímos por esse meio as tiras referentes à Copa de 2014. A parte do corpus referente a 1994 desse jornal teve de ser coletada em consultas ao acervo da Biblioteca Nacional de Buenos Aires e à Biblioteca del Congreso Nacional. Nesses casos, devido ao precário estado de conservação de alguns exemplares, a visibilidade de algumas das tiras está prejudicada. Ressalvamos que no caso específico das tiras Clemente, de autoria de Caloi e muito relevantes para a análise, tivemos a sorte de encontrar algumas das publicações reproduzidas na coletânea Clemente es Mundial, uma seleção de tiras do personagem publicadas no Clarín que têm como tema os campeonatos mundiais de futebol de 1978 a 2010.

No que diz respeito aos períodos considerados para a coleta, os primeiros dias coincidem com o início de cada um dos campeonatos, já o último vai um pouco além do término oficial das Copas estudadas. Na escolha das tiras que integrariam o corpus, consideramos aquelas publicadas até dois dias após o jogo final em que se definiram o primeiro e o segundo lugar do campeonato daquele ano. Esse intervalo dois dias maior que o período oficial se deve a uma característica estrutural do meio com que trabalhamos. Diferentemente de um portal de notícias na web ou do blog de um quadrinista, em que o tempo decorrido entre a finalização de um texto, de uma tira, ou de

\footnotetext{
${ }^{3}$ http://acervo.folha.uol.com.br/

${ }^{4} \mathrm{http}: / /$ kiosco.clarin.com/
} 
uma charge e sua publicação é muito curto, em um jornal de circulação diária, e em papel - como o caso de que nos ocupamos - é preciso mais tempo para que isso aconteça, por isso consideramos os dois dias após o encerramento. Embora exista a possibilidade de o quadrinista haver deixado duas tiras diferentes, uma para cada resultado, para o editor selecionar aquela que condizia com o resultado final, acreditamos que trabalhando com esse prazo de dois dias pudemos ter uma margem que nos possibilitou encontrar tiras que nos proporcionaram dados relevantes para os resultados finais. No recorte final, foram analisadas tiras que se referem a momentos específicos das campanhas de 1994 e 2014 dos dois países e que serão apresentadas sob a forma de estudos de caso. Nesse processo, temos consciência de que muitos dados tiveram de ser deixados de lado. Temos plena consciência de que o que apresentamos são algumas leituras possíveis considerando nosso instrumental teórico-analítico, mas que outras seriam não só possíveis como legítimas.

\section{Organização da tese}

Esta tese está organizada em duas grandes partes. A primeira está formada pelos três primeiros capítulos e neles apresentamos o arcabouço teórico e conceitual que fundamentou nossa investigação.

No primeiro capítulo, trazemos as contribuições dos estudos discursivos, enfocamos o conceito de gênero discursivo e, para fundamentar a análise, estabelecemos uma interface com a noção bourdieusiana de campo social. Também apresentamos a noção de cena da enunciação (MAINGUENEAU, 2001, 2010) que operacionalizou a análise.

O segundo capítulo tem por tema o humor. Apresentamos o recorte que fizemos dos estudos a esse respeito e introduzimos a proposta de Charaudeau (2006) para análise do discurso de humor, cujas categorias foram usadas para abordar a dimensão humorística das tiras cômicas nas análises que são tema do capítulo 5.

No terceiro capítulo, nos dedicamos às reflexões baseadas nas leituras que efetuamos sobre as pesquisas que têm o futebol como objeto de estudo e seu papel na construção identitária do Brasil e da Argentina.

A segunda parte de nossa tese traz a dimensão mais propriamente analítica do trabalho. Seguindo o enfoque para a noção de cena da enunciação introduzida por Maingueneau (2001, 2010), no primeiro deles, o capítulo quatro, abordamos o quadro cênico das tiras cômicas, a saber, a cena englobante e a cena genérica. Nesse capítulo 
refazemos o percurso histórico do gênero tira cômica e sua relação com os jornais diários na Argentina e no Brasil, ou seja, discorremos sobre sua estabilização no campo do humor gráfico e quadrinhos e interpretamos as consequências das diferentes condições sócio-históricas em que esse processo se deu nos dois países. Ademais, refletimos também sobre o importante papel dos jornais Clarín e Folha de S. Paulo para o campo das tiras cômicas de produção local na Argentina e no Brasil.

O capítulo 5 traz a análise, em forma de estudos de caso, de um conjunto de tiras publicadas nos jornais mencionados por ocasião da realização das Copas de 1994 e 2014. $\mathrm{Na}$ introdução do respectivo capítulo estão descritos os procedimentos seguidos e sua organização interna. Ao longo das distintas partes que o compõem foram apresentadas conclusões parciais e ao final dele, discutimos os dados que se relevaram em uma perspectiva comparada.

No capítulo 6 apresentamos nossas conclusões a respeito deste trabalho, avaliamos as possíveis contribuições e apontamos suas limitações. 


\section{PARTE 1 - ARCABOUÇO TEÓRICO E CONCEITUAL}

\section{CAPÍTULO 1: Aportes dos estudos discursivos}

\section{Introdução}

Neste capítulo, apresentamos os fundamentos de nosso trabalho relacionados mais diretamente à sua dimensão linguístico-discursiva. Esses fundamentos estão balizados por reflexões do campo da sociologia da cultura, que nos ajudaram a circunscrever nosso olhar sobre o objeto de estudo desta pesquisa e que igualmente apresentamos.

Começaremos pelo conceito de gênero discursivo, discorrendo sobre como foi entendido neste trabalho e apontando as linhas teóricas e investigativas com que nos alinhamos ao elegê-lo como objeto de estudo. Refletiremos depois sobre a relação entre gênero e espacialidade social, apoiando-nos no conceito de campo de Bourdieu (2002).

Em seguida abordaremos as reflexões conceituais que nos auxiliaram na operacionalização da análise: o conceito de cena da enunciação de Maingueneau (2008b) e as quatro outras dimensões em que ele o divide: cena englobante, cena genérica, cenografia e cena validada. Também discutiremos as noções de estereótipo, memória e ethos. Finalizamos apresentando os conceitos de particitação e hiperenunciador, que também foram mobilizados no trabalho de análise.

\section{Sobre o conceito de gênero}

\subsection{Antecedentes}

Temos atualmente uma grande diversidade de fontes teóricas e perspectivas de análise envolvendo o conceito de gênero - seja identificando-o como textual, discursivos ou do discurso ${ }^{5}$ - no âmbito dos estudos da linguagem. Pontuamos que usaremos neste trabalho o termo gênero discursivo ou gênero do discurso, visto que pretendemos explorar as tiras cômicas de uma perspectiva discursiva e enunciativa, não sendo a dimensão textual o foco do olhar analítico. Como se trata de uma noção central em nosso trabalho,

\footnotetext{
${ }^{5}$ Para uma reflexão a respeito da não intercambialidade entre as designações - gênero textual, gênero discursivo - remetemos à leitura de Rojo (2008). Já em Brait e Pistori (2012) encontramos reflexões sobre o percurso do conceito de gênero ao longo de diversas obras do Círculo de Bakhtin.
} 
foi preciso efetuarmos escolhas e recortes nessa profusão de estudos, os quais passamos a apresentar, discutir e justificar nas linhas que seguem.

Como é sabido, os estudos sobre gêneros têm sua origem na Antiguidade. No Ocidente, o termo esteve durante muito tempo associado aos estudos literários. Marcuschi (2008, p. 147) nos lembra que as reflexões sobre o tema contam com pelo menos vinte e cinco séculos de existência. Sua sistematização inicia-se com Platão e Aristóteles e, conforme Machado (2005, p. 151), nessa visão clássica as formas poéticas eram definidas em termos de classificação paradigmática e hierarquização, privilegiando-se as propriedades formais dos gêneros identificados.

No âmbito da tradição crítica literária, o uso da teoria dos gêneros para classificar as diferentes produções escritas atravessa os períodos históricos, mas não de forma homogênea e unívoca. No verbete gênero em seu Dicionário de Análise do Discurso, Maingueneau e Charaudeau (2004, p. 249) chamam a atenção para o fato de que nos estudos literários a noção de gênero como categoria classificatória foi utilizada segundo critérios nem sempre da mesma natureza. Os autores citam, por exemplo, classificações que respondem a (i) critérios de composição, forma e conteúdo, na qual encontramos a distinção entre poesia, teatro, romance, ensaio e depois subdivisões no interior de cada um desses gêneros, tais como a tragédia, o drama e a comédia para o teatro, o épico e o elegíaco para a narrativa etc.; (ii) critérios relacionados às diferentes maneiras de representação da realidade, a Escolas dentro de períodos históricos, tais como os gêneros romântico, realista e surrealista, e (iii) critérios que remetem à estrutura do texto e à sua organização enunciativa na qual se encontram, entre outros, a autobiografia, o romance histórico, o fantástico.

A ampliação do uso da noção de gênero a outros campos que não o literário tem início nos primórdios do século XX segundo Marcuschi (2008, p.147). Machado (2005, p. 152), por sua vez, menciona a emergência da prosa comunicativa e a necessidade de outros parâmetros de análise como fator desestabilizante do estatuto dos gêneros literários. Segundo a autora, no campo dessa emergência encontram-se os estudos desenvolvidos por Mikhail Bakhtin e seu Círculo, que proporcionarão os pilares que fundamentam nosso trabalho. 


\subsection{A reconceituação a partir do Círculo de Bakhtin}

No campo da Linguística, as reflexões oriundas do Círculo de Bakhtin representaram um verdadeiro ponto de virada. Rompendo com o subjetivismo da estilística das primeiras décadas do século XX e a abstração da linguística estrutural e do formalismo russo (ROJO, 2008, p. 95), instauraram uma nova visão de língua e de linguagem, que passam a ser concebidas privilegiando-se sua natureza sócio-histórica, interativa e funcional e não a formal e estrutural. Rojo (2008) destaca ainda que o foco de Bakhtin, seu corpus de trabalho e o problema privilegiado eram o romance polifônico (Dostoievski, Rabelais). Assim, ter como objetos de estudo a teoria da enunciação e o romance polifônico demandou do Círculo uma revisão do conceito de gênero literário, estendendo-o "para além das fronteiras da arte verbal: para a vida e para a ética, para além da estética" (op. cit., p. 95). A autora assinala que ao longo do desenvolvimento das reflexões bakhtinianas operou-se um deslocamento sucessivo da noção de gêneros literários para gêneros linguísticos (BAKHTIN/VOLOSHÍNOV, 1986, p. 43) e, finalmente, para gêneros discursivos ${ }^{6}$ (BAKHTIN, 1992). Assim, com as reflexões do Círculo, o conceito é estendido para todas as formas de discurso da vida e da atividade humana e recolocado de forma sociossituada, no fluxo das mais variadas formas de relação social (esferas ou campos de atividade humana) (ROJO, 2008, p. 95, grifos conforme o original). Em lugar da concepção a partir de um ponto de vista paradigmático e classificatório, os gêneros passam a ser enfocados a partir do dialogismo de todo processo comunicativo, das relações interativas que produzem linguagem.

Para Bakhtin, toda e qualquer comunicação humana - verbal ou escrita - ocorre a partir de gêneros discursivos, compostos por sua vez por enunciados construídos e proferidos por falantes em situações inseridas em um contexto sócio-histórico. Nas palavras do próprio autor, esses enunciados:

reflejan las condiciones específicas y el objeto de cada una de las esferas [de la praxis humana] no sólo por su contenido (temático) y por su estilo verbal, o sea, por la selección de los recursos léxicos, fraseológicos y gramaticales de la lengua, sino, ante todo, por su composición o estructuración. Los tres momentos mencionados - el contenido temático, el estilo y la composición - están vinculados indisolublemente en la totalidad del enunciado y se determinan de un modo semejante, por la especificidad de una esfera dada de comunicaciones. Cada

\footnotetext{
${ }^{6}$ Essa é a forma que consta na tradução ao espanhol que utilizamos, embora no Brasil a tradução do mesmo texto tenha adotado o termo gêneros do discurso.
} 
enunciado separado es, por supuesto, individual, pero cada esfera del uso de la lengua elabora sus tipos relativamente estables de enunciados, a los que denominados géneros discursivos. ${ }^{7}$ (BAKHTIN, [1953] 2008, p. 247)

Destacamos do fragmento citado primeiramente o que terminou por ficar conhecido como a definição de gênero para Bakhtin: "tipos relativamente estáveis de enunciados" elaborados no interior de cada uma das atividades humanas. Na disseminação dos estudos sobre gêneros, uma boa parte deles - especialmente aqueles relacionados à aplicação do conceito no ensino de língua materna e estrangeira - terminou por enfatizar o substantivo "tipos" e o adjetivo "estáveis", por vezes apagando o advérbio relativamente. Faraco (2003, p. 103), a esse respeito, esclarece que ao dizer que os tipos são relativamente estáveis, Bakhtin "está dando relevo, de um lado, à historicidade dos gêneros; e, de outro, à necessária imprecisão de suas características e fronteiras”. Assim, trata-se de uma compreensão que articula estabilidade e mudança; "reiteração, (à medida que aspectos da atividade recorrem) e abertura para o novo (à medida que aspectos da atividade mudam)". Acrescentamos que Marcuschi (2008, p. 151) a esse mesmo respeito afirma que os gêneros constituem uma listagem aberta e são definidos mais por seus aspectos sociocomunicativos e funcionais que pelos aspectos formais. Portanto, não devem ser compreendidos como modelos estanques ou estruturas rígidas em que só a forma importa, mas sim como entidades dinâmicas dotadas de algumas características que lhes conferem identidade.

Do fragmento de Bakhtin citado anteriormente ressaltamos ainda a menção às três dimensões que compõem os gêneros discursivos, a saber: tema, estilo e forma composicional. Para delimitar o entendimento de cada uma dessas três dimensões, recorremos novamente a Rojo (2005, p.196). Conforme a autora, cujos destaques reproduzimos nos negritos, o tema corresponde aos conteúdos ideologicamente conformados que se tornam dizíveis mediante o gênero; o estilo refere-se às configurações específicas das unidades de linguagem, aos traços da posição enunciativa do locutor e por fim, a forma composicional diz respeito aos elementos das estruturas comunicativas e semióticas compartilhadas pelos textos pertencentes ao gênero. Ainda segundo a autora, as três dimensões são determinadas "pelos parâmetros da situação de produção dos enunciados e sobretudo, para Bakhtin/Voloshinov (1929) pela apreciação

\footnotetext{
${ }^{7}$ Seguindo o mesmo procedimento adotado por outros trabalhos defendidos no programa de pós-graduação em este trabalho foi desenvolvido, não traduziremos as citações em espanhol.
} 
valorativa do locutor a respeito do(s) tema(s) e do(s) interlocutor(es) de seu discurso." (ROJO, 2005, p. 196). Por "situação de produção dos enunciados" entende-se um conjunto de circunstâncias em que as variáveis de pessoa, tempo e espaço são social e historicamente situadas.

Cabe acrescentar ainda a noção de dialogismo, basilar no pensamento do Círculo de Bakhtin, compreendida não só como a presença implícita do "outro" a quem todo enunciado se destina, como também a relação estabelecida entre esse enunciado e outros que o antecederam. No texto El problema de los géneros discursivos que já citamos, encontramos a seguinte formulação a esse respeito:

todo hablante es de por sí un contestatario, en mayor o menor medida: él no es un primer hablante, quien haya interrumpido por vez primera el eterno silencio del universo, y él no únicamente presupone la existencia del sistema de la lengua que utiliza, sino que cuenta con la presencia de ciertos enunciados anteriores, suyos y ajenos, con los cuales su enunciado determinado establece toda suerte de relaciones (se apoya en ellos, polemiza con ellos, o simplemente los supone conocidos por su oyente). Todo enunciado es un eslabón en la cadena muy complejamente organizada, de otros enunciados (BAKHTIN, 1953/2008, p.255).

Assim, apoiados em Bakhtin, entendemos que toda e qualquer comunicação se dá configurada em um gênero e em relação dialógica tanto do falante com o(s) outro(s) a quem o enunciado se destina, como na relação que esse enunciado, e por conseguinte o gênero em que está inserido, mantém com outros existentes. Maingueneau (2010, p. 130) refere-se aos gêneros como "dispositivos de comunicação sócio-historicamente condicionados", suas características, portanto, respondem às dimensões sócio-históricas de sua produção e recepção. Pelo exposto, podemos concluir que ao estudarmos um gênero em uma dada sociedade, explorando a relação entre as características discursivoenunciativas desse gênero, a espacialidade social e as circunstâncias históricas, poderemos recuperar diferentes dados sobre essa sociedade.

\section{Gêneros discursivos e espacialidade social}

Para abordar o tema enunciado no subtítulo, e para delimitar um pouco mais a perspectiva com a qual trabalhamos, trazemos algumas reflexões de Jean-Claude Beacco (2004) e o diálogo que Fanjul (2015) estabelece com elas. Em seu artigo, o linguista francês agrupa os estudos linguísticos dos gêneros discursivos em três perspectivas, 
descreve e exemplifica cada uma delas. A primeira seria aquela em que os gêneros são vistos como "forma da experiência ordinária da comunicação". Nessa perspectiva interessaria explorar como os falantes identificam e se referem a gêneros tais como um depoimento, uma propaganda, mesmo sem ter deles um conhecimento propriamente formalizado. Nas palavras do autor $\left(2004\right.$, p.112) ${ }^{8}$ :

O programa de uma linguística dos gêneros, nesta perspectiva, envolve o estudo científico das representações metalinguísticas comuns, que concernem à linguagem, às linguas, sua aprendizagem..., como elas são ativadas, construídas ou reelaboradas na interação verbal sob a forma, por exemplo, de definições ou de opiniões, por não especialistas em linguagem. Encontra-se, em grande medida, ainda por ser realizada ${ }^{9}$.

A segunda perspectiva apontada por Beacco é aquela que explora os gêneros discursivos como tipos de textos. A partir desse ponto de vista, os gêneros são abordados como categorias prototípicas e os estudos se ocupam de suas características formais e composicionais.

A terceira perspectiva - a que nos interessa mais de perto - é aquela que relaciona os gêneros discursivos e a espacialidade social. Na introdução a essa parte do artigo, Beacco (2004, p.116) afirma que o projeto da análise do discurso é "articular as formas discursivas a seus lugares, definidos mais amplamente que pelas dimensões da situação de enunciação, que é um construto de natureza linguística, sem dimensões sociais"10. Reteremos desse fragmento, por sua pertinência para o nosso trabalho, que articular as formas discursivas a lugares, implica ir além da situação de enunciação como a instauração das coordenadas de pessoa, tempo e espaço, mas incluir também a dimensão social e histórica em que se instala essa situação.

Beacco identifica duas formas principais pelas quais essa terceira perspectiva é levada a cabo nas pesquisas, com um traço comum entre elas que seria o de "constituir um dispositivo interpretativo explícito de regularidades linguísticas observadas nos

\footnotetext{
${ }^{8}$ As traduções de citações de Beacco são uma versão revista por nós da tradução ao português efetuada por Ana Gleyse Moura de Brito e publicada no Brasil em 2013, conforme consta nas referências bibliográficas.

9 "Le programme d'une linguistique des genres, instaurée dans cette perspective, relève de l'étude scientifique des représentations métalinguistiques ordinaires (BEACCO, 2001), qui concernent le langage, les langues, leur apprentissage..., telle qu'elles sont activées, construites ou réélaborées dans l'interaction verbale, sous forme, par exemple, de définitions ou d'opinions, par des non-specialistes du langage. Il demeure largement à réaliser."

10 "articuler des formes discursives à des lieux, définis de manière plus large que par les dimensions de la situation d'enonciation, qui est un construit de nature linguistique, sans dimensions sociales".
} 
gêneros discursivos ou no corpus de textos constituídos sobre bases não genéricas"11 (opus cit, p. 116). A primeira delas se ocuparia de identificar essas regularidades principalmente no uso de elementos lexicais e em revelar "o sentido social" resultante desse uso. A interpretação consiste em desmontar a esquematização, como produto/processo, descrevendo-a, e em localizá-la nas formações discursivas, que têm uma natureza ideológica e historicamente constituída. Cita como exemplo, as análises com base em paradigmas designacionais.

A outra das formas identificadas por Beacco na perspectiva que relaciona gêneros a lugares sociais é aquela em que, com certa ressalva que explicitaremos, vemos inserido nosso trabalho. Segundo o autor, ela se centra tanto nos gêneros como em suas formas e mais que identificar as regularidades presentes, se ocupa de interpretá-las. Nas palavras de Beacco (2004, p.116) trata-se de compreender

não a forma de textos em relação com um gênero discursivo (identificação de regularidades) mas as formas dos gêneros discursivos em relação com os lugares de produção, difusão e recepção nos quais se inscrevem e que os caraterizam (interpretação de regularidades). ${ }^{12}$

Para tanto, sugere como um caminho metodológico para a análise explorar os espaços sociais em que os gêneros discursivos se inserem usando o conceito de comunidade discursiva. Esclarece ele (op. cit., p. 117) que:

Não se trata tanto de retornar à sociologia da comunicação, mas sim de construir, em concordância com os dados, o conceito de configurações etno-sócio-históricas que permite descrever os efeitos linguísticos dialéticos desta localização dos gêneros discursivos sobre a estruturação dos lugares sociocomunicativos e desses lugares sobre as formas linguísticas dos gêneros discursivos ${ }^{13}$.

Vemos que Beacco retoma a ideia de comunidade discursiva, proposta e usada tanto na etnografia da comunicação como na análise do discurso, entendendo-a como uma categoria espacial, nem estritamente sociológica, nem unicamente linguística. Mariana di Stefano (2015) interpreta a noção de comunidade de Beacco como espaços sociais de

\footnotetext{
11 “constituer un dispositiv interprétatif explicite des régularités linguistiques observées dans les genres discursifs ou même dans des corpus de textes constitués sur des bases non génériques".

12 "non de la forme de textes par rapport à un genre discursif (identification des régularités), mais de formes des genres discursifs par rapport à des lieux de producrion, de diffusion et de réception dans lesquels ils s'inscrivent et qu'ils caractérisent (interprétation des régularités)"

${ }^{13}$.Il ne s'agit pas tant de verser dans la sociologie de la communication que de construire, en concordance avec les données, le concept de configurations ethno/socio-historiques qui permette de décrire les effets linguistiques dialectiques de cette localisation des genres discursifs sur la structuration des lieu sociocommunicatifs et de ces lieux sur les formes linguistiques des genres discursifs.
} 
relativa estabilidade no uso da linguagem. Para caracterizar as diferentes comunidades, Beacco propõe alguns descritores - que esclarece serem provisórios - que poderiam desenhar a infraestrutura dos dispositivos de interpretação para a análise. Trata-se de uma reflexão que se insere em uma pesquisa maior realizada por ele anteriormente (BEACCO: 1999) sobre o discurso de vulgarização da astronomia, na qual explora a relação entre espacialidade social e gêneros discursivos.

Beacco considera que o espaço midiático, do qual também fazem parte os jornais diários de onde extraímos nosso corpus, constitui um mercado de gêneros discursivos, alimentado pelas comunidades discursivas que produzem as mercadorias, a saber, os bens culturais atribuídos a determinados gêneros. Segundo o autor, como se trata de um mercado, o espaço midiático estaria condicionado por estratégias de oferta e demanda, nas quais as expectativas do público encontram-se também presentes.

Por outro lado, Maingueneau (2002) em texto em que trabalha com o conceito de comunidade discursiva, exclui de sua aplicação justamente os gêneros produzidos no espaço midiático. Ele parte da distinção entre discursos fechados e discursos abertos, efetuada por ele próprio em trabalho anterior (MAINGUENEAU: 1992). Os primeiros seriam aqueles em que os locutores e os destinatários tenderiam a coincidir quantitativa e qualitativamente, como por exemplo, no caso dos gêneros do discurso científico, cujo público é praticamente aquele que escreve textos dos mesmos gêneros. Já no caso dos gêneros dos discursos abertos, há uma enorme diferença entre aqueles que os produzem e seus receptores. Segundo Maingueneau (2002), tanto no caso da imprensa como do discurso político temos exemplos em que a população dos produtores dos gêneros são grupos muito restritos e de forte identidade, que se dirigem a populações amplas e variadas de receptores, com características sociais normalmente muito diferente da dos produtores. Como nosso corpus está formado por tiras cômicas publicadas em jornais diários de circulação massiva, entendemos que os aspectos elencados por Maingueneau para os discursos abertos se aplicam também a ele.

Mas antes de explicitar como solucionamos a questão, voltemos a Beacco, pois ele faz ainda uma consideração importante com relação ao espaço midiático. Segundo o autor, esse espaço "tende a ser confundido com o espaço público das comunidades sóciopolíticas, onde opiniões e valores circulam e se confrontam" ${ }^{14}(2004$, p.118). Essa consideração introduz uma variável importante na reflexão proposta pelo autor francês,

\footnotetext{
14 “tend à se confondre avec l'espace public des communautés socio-politiques, qui est celui où sont mis en circulation et se confrontent opinions et valeurs"
} 
que nos remete justamente às observações tecidas por Fanjul (2015) a respeito da aplicabilidade da noção de comunidade discursiva proposta por Beacco a gêneros da cultura de massa que circulam no espaço midiático. No artigo mencionado, Fanjul reflete sobre as possibilidades que categorias como gênero, formação discursiva e percurso oferecem em pesquisas comparadas que confrontam corpora de textos produzidos em línguas e países diferentes, mas comparáveis por seu papel sócio-histórico. Para Fanjul, e concordamos com seu ponto de vista, a noção de comunidade discursiva pressupõe "fronteiras nítidas demais para o que pode ser o difuso conjunto dos produtores e consumidores de alguns tipos de bens culturais" (FANJUL, 2015, p. 511), especialmente daqueles que combinam uma circulação externa e interna aos meios de comunicação de massa. Acrescenta ainda que embora reconheça a necessidade de nas pesquisas diferenciar metodologicamente "os grupos de produtores mais diretamente relacionados a uma prática discursiva e os espaços midiáticos em que alguns dos produtos de essa prática circulam" (idem), a relação entre eles deve ser vista não em termos de estratégias, mas, sim, de relação de forças, "com a indústria cultural como inserida e atuante nessas relações de forças" (ibidem), para que não se corra o risco de apagar o conflito inerente a toda formação social. Com relação a Beacco (2004), de nosso ponto de vista, a observação introduzida por ele a respeito do espaço midiático, considerando sua potencial intersecção com "o espaço público das comunidades sócio-políticas, onde circulam e se confrontam opiniões e valores" (op. cit. p. 118) poderia ser vista como uma ressalva a respeito da aplicabilidade da noção de comunidade discursiva em pesquisas que abordam os gêneros no âmbito da comunicação de massa, justamente a posição adotada por Maingueneau (2002) que citamos anteriormente e que, como já destacamos, diz respeito também ao corpus com que trabalhamos. Em certa medida, portanto, corrobora a posição de Fanjul no que se refere a ver a relação entre os atores envolvidos na produção, circulação, recepção e consumo dos gêneros no espaço midiático mais como uma relação de forças e não de estratégias.

Assim, embora adotemos a perspectiva identificada por Beacco (2004) de análise dos gêneros discursivos vinculando-os à espacialidade social, para levar nosso trabalho a cabo não adotaremos a noção de comunidade discursiva, visto que, como exposto acima, ela não se aplica ao âmbito de um gênero discursivo - tiras cômicas - que circula em jornais de alcance nacional como são A Folha de S. Paulo e o Clarín. Concordamos e nos alinhamos, portanto, com as considerações de Fanjul (2015), quem considera que a noção de comunidade discursiva não traduz a correlação de forças que estão em jogo no âmbito 
das produções que analisamos. A perspectiva adotada por esse autor nos parece mais apropriada, qual seja, discutir os lugares sociais em que o gênero se insere a partir da noção bourdieusiana de campo, que abordaremos na próxima seção apresentando também como a usaremos em nosso trabalho.

\subsection{Campo social}

Tendo em vista os objetivos de nosso trabalho, não faremos aqui uma apresentação aprofundada e completa da teoria bourdieusiana, nos limitaremos a expor sinteticamente o conceito de campo para em seguida estabelecer um diálogo entre ele e nossa pesquisa.

É possível identificar ao longo da vasta produção de Bourdieu que a intenção de construir elementos que permitissem fundamentar uma sociologia da cultura ocupa um lugar central. Nesse sentido, vários dos conceitos e da lógica de análise propostos pelo sociólogo francês dizem respeito a compreender e a explicar os diferentes âmbitos de produção e consumo de bens simbólicos. Gutiérrez, na apresentação da obra do autor (2010, p.10), aponta que as reflexões de Bourdieu nasceram com o intuito de encontrar uma alternativa às duas principais correntes nas análises de obras culturais vigentes nos anos 60, a saber:

(i) aquelas que explicam a evolução interna das ideias ou das formas artísticas em si como um tipo de universo puro e isolado do mundo social que as produz, e

(ii) aquelas que o fazem identificando a produção estética com a classe social a que seu produtor pertence.

Ambas, segundo a autora, têm em comum "el hecho de ignorar que las prácticas que se analizan se insertan en un universo social específico, un campo de producción específico, definido por sus relaciones objetivas" (idem).

No pensamento bourdieusiano, portanto, os campos constituem espaços sociais estruturados ao redor de uma prática, que possuem leis de funcionamento próprias e historicamente construídas. São espaços de lutas e de disputa, por isso assemelhados ao jogo, nos quais participam agentes que ocupam posições desiguais devido aos diferentes tipos de capital que possuem. Além do econômico, Bourdieu distingue o capital social, o cultural e o simbólico, sendo este último uma síntese dos anteriores. Segundo Bourdieu (2002, p. 120, grifo do próprio autor): 
La estructura del campo es un estado de la relación de fuerzas entre los agentes o las instituciones que intervienen en la lucha o, si ustedes prefieren, de la distribución del capital específico que ha sido acumulado durante luchas anteriores y que orienta las estrategias ulteriores.

Ao enfatizar o termo estado, Bourdieu está dando relevância ao fato de que a estrutura de um campo é apreendida em um momento histórico determinado e a que os campos não são estáticos, a relação de forças que os constituem também os tornam mutáveis e sujeitos à influência de fatores econômicos, sociais, de reconfiguração da própria sociedade em que está inserido.

Outro ponto importante a esse respeito é que, para Bourdieu, pensar um campo social como um campo de lutas implica ter em mente que os agentes envolvidos nessas disputas, embora possuam posições desiguais, possuem interesses comuns relacionados à própria existência do campo. A esse respeito, Gutiérrez, ainda na apresentação da obra (2010, p.13), e retomando de Bourdieu a comparação entre campo e jogo, esclarece que se trata de

una suerte de complicidad básica, un acuerdo entre los antagonistas acerca de lo que merece ser objeto de lucha, el juego, las apuestas, los compromisos, todos los presupuestos que se aceptan tácitamente por el hecho de entrar en el juego.

Para que um campo funcione, por conseguinte, é preciso que haja pessoas dispostas a participar dele, que conheçam e reconheçam suas leis imanentes e acreditem no valor do que está em jogo.

Embora Bourdieu não tenha elencado elementos formais para caracterizar a constituição de um campo autônomo, os trabalhos que aplicam o conceito normalmente consideram se, além dos produtores e consumidores dos gêneros que circulam nesse campo, existem instituições, eventos próprios e crítica especializada (a metalinguagem) funcionando ao redor da prática que está sendo objeto de análise.

Para relacionar essa contribuição da sociologia ao nosso trabalho, começaremos retomando as considerações de Fanjul (2015) anteriormente citadas. Como mencionamos, o autor elabora suas reflexões no contexto de estudos discursivos comparados cujos objetos são gêneros produzidos em línguas e países diferentes. Segundo ele, um gênero discursivo, como um conjunto de enunciados, não constitui per se um campo ou um subcampo na perspectiva bourdieusiana, mas juntamente com seus produtores e consumidores, as instituições em que se insere, a crítica a seu respeito, pode vir a 
constituir um. Acrescenta que para o tipo de pesquisa comparativa a que o artigo se refere considera

fundamental localizar a situação de cada gênero em cada país em relação com campos e subcampos, e sua implantação desigual nas hierarquias do mercado de bens simbólicos; isso tanto para os gêneros de existência internacional quanto para aqueles mais locais entre os quais procuramos analogias.

Entendemos que as reflexões de Fanjul (2015) podem ser aplicadas ao nosso trabalho visto que também comparamos um gênero discursivo, a tira cômica, produzido em línguas e países diferentes, abordando seus aspectos enunciativo-discursivos e, consequentemente, também a espacialidade social em que se insere em ambos os países.

Isto posto, no recorte teórico-metodológico que efetuamos com base em Bourdieu, consideramos que ao enfocar as tiras cômicas estamos trabalhando em termos gerais com o grande campo de "produção, circulação e consumo de bens simbólicos" (BOURDIEU, 2007, p. 99), que entendemos como sendo o campo cultural. Fazem parte desse campo maior vários outros campos e subcampos e entre eles localizamos o que designaremos como campo do humor gráfico e quadrinhos, no caso do Brasil, ou campo del humor gráfico y cómics ou historietas, no caso da Argentina ${ }^{15}$, no qual circulam diferentes gêneros que mesclam o verbal e o visual. A título meramente ilustrativo citamos os vários tipos de histórias em quadrinhos - de humor, de aventura, ficção científica etc - novelas gráficas, charges, cartuns, caricaturas, as tiras cômicas e várias outras produções. Trata-se de uma escolha à qual chegamos após constatar uma oscilação na designação usada pelos diferentes agentes sociais envolvidos nesse campo. Em alguns eventos - acadêmicos ou não -, bem como na produção metalinguística a respeito desse campo, faz-se uma distinção entre as produções que pertenceriam ao campo do humor gráfico - caricaturas e charges - e as narrativas quadrinizadas - tiras ou histórias maiores ${ }^{16}$. E há outros que parecem usar tanto humor gráfico como quadrinhos/historieta/cómic como o rótulo maior que conteria a outra designação. Constatamos, portanto, uma oscilação na designação que

\footnotetext{
${ }^{15}$ Por razões de praticidade, adotaremos o termo campo do humor gráfico e quadrinhos para ambos os países.

${ }^{16}$ A título de exemplo, citamos as três edições $(2010,2012,2014)$ do congresso bienal Viñetas serias Congreso Internacional de Historietas y Humor gráfico realizado em Buenos Aires, Argentina e a mesaredonda Mercado de trabalho para desenhistas de quadrinhos e humor gráfico ocorrida em fevereiro de 2014 durante a exposição Cidades em Tiras: A Metrópole Brasileira através das Histórias em Quadrinhos no Sesc Santo André
} 
pode ser interpretada como um indício de que "quadrinhos", no caso do Brasil, e "cómics ou historietas" no caso da Argentina, como rótulos não são suficientes para abarcar a complexidade e a variedade das produções que circulam nesse campo. Como não se trata de uma questão central em nosso trabalho, optamos por solucioná-la usando a dupla designação no recorte.

Assim, com fundamento nas contribuições que buscamos na sociologia da cultura para nosso trabalho e, em certa medida, com o aval de pesquisas assemelhadas que foram realizadas no âmbito dos estudos discursivos, optamos, portanto, por um recorte teóricometodológico em que situamos as tiras cômicas, juntamente com todos os agentes e práticas envolvidas em sua produção, circulação e consumo - como um dos gêneros ao redor dos quais se estrutura o campo do humor gráfico e quadrinhos. Como detalhado no capítulo 4, no qual descrevemos a historicidade do gênero tiras cômicas em ambos os países com os quais trabalhamos, embora guardem pontos em comum, na Argentina e no Brasil os respectivos campos têm também suas especificidades, especialmente no que se refere à consolidação da produção local da tira cômica, que, como já afirmamos, é um dos gêneros que dele faz parte. E não poderia ser de outra forma, visto que estamos lidando com distintos contextos sócio-históricos, agentes e seus correspondentes capitais.

\subsection{O humor como campo discursivo}

A noção de campo discursivo foi proposta por Maingueneau (2010) nos anos setenta a partir do conceito de campo de Bourdieu. Em Campo discursivo - a propósito do campo literário, o autor justifica a reformulação do conceito bourdieusiano esclarecendo que nas pesquisas em análise do discurso é necessário ir além de um raciocínio "em termos de atores, de posições e de lutas pela autoridade. É preciso traduzir isso em termos de identidade enunciativa" (MAINGUENEAU, 2010, p. 50). Nesse sentido, considera um campo discursivo como

um espaço no interior do qual interagem diferentes "posicionamentos", fontes de enunciados que devem assumir os embates impostos pela natureza do campo, definindo e legitimando seu próprio lugar de enunciação. Esse campo discursivo, onde os diversos posicionamentos estéticos investem cada um à sua maneira gêneros de textos e variedades linguísticas, não é uma estrutura estática, mas um jogo de equilíbrio instável. (Idem). 
Ao longo do texto citado, Maingueneau (2010) desenvolverá reflexões e análises para caracterizar o campo discursivo literário. A partir dessa caracterização, Sírio Possenti (2010) propõe uma espécie de programa a ser encampado por investigadores da área no sentido de que, por analogia com o campo literário, o humor seja visto como um campo discursivo e expõe razões para fundamentar sua proposta, bem como questões a serem enfrentadas. Embora as reflexões que Possenti desenvolveu como pesquisador sobre o humor tenham contribuído em diferentes momentos de nosso trabalho, entendemos que em nosso caso o humor, como uma dimensão constitutiva de nosso objeto de estudo, estará contemplado em nossa interpretação de sua cena englobante, conceito que será detalhado nas linhas seguintes deste capítulo. O próprio Maingueneau, quem desenvolveu a ideia, afirma tratar-se de uma categoria operacional a ser determinada pelo pesquisador.

O exposto até este momento compreende os aspectos macroanalíticos de nosso trabalho, passaremos na próxima seção a expor os conceitos e subsídios teóricos que foram mobilizados para operacionalizar a análise.

\section{A cena da enunciação}

Maingueneau propõe o conceito de cena da enunciação a partir de sua abordagem do texto literário pela análise do discurso e o vai aperfeiçoando ao longo de sua produção acadêmica. Trata-se na verdade de uma tríade de conceitos - que podem vir a ser quatro, como veremos - que podem ser concebidos como círculos concêntricos em uma relação de interdependência: a cena englobante, a cena genérica e a cenografia.

A cena englobante corresponde ao "tipo de discurso". Trata-se de uma classificação que remete ao "setor" da sociedade de onde um provém um texto e que define o status dos parceiros em um certo espaço pragmático. Maingueneau cita que quando recebemos um panfleto na rua, por exemplo, devemos ser capazes de determinar a que tipo de discurso ele pertence: religioso, político, publicitário, ou seja, em que cena englobante nos devemos posicionar para interpretá-lo e saber em nome de que ele interpela quem o recebe. Um panfleto político implica um cidadão dirigindo-se a cidadãos, uma publicidade implica uma empresa, um serviço e potenciais clientes etc.

A cena genérica, como se pode depreender, corresponde ao gênero do discurso. Às condições de enunciação que cada gênero pressupõe corresponde um certo número de expectativas do público e de antecipações possíveis dessas expectativas pelo autor. Conforme Maingueneau, essas duas cenas correspondem ao quadro cênico de um texto, 
“é ele que define o espaço estável no interior do qual o enunciado adquire sentido" (2001, p. 82).

A cenografia, por sua vez, corresponde à cena que o próprio discurso institui. Conforme esclarece o autor, não devemos considerá-la como sinônimo de um cenário, de um quadro,

como se o discurso aparecesse inesperadamente no interior de um espaço já construído e independente dele. (...) A cenografia implica (...) um processo de enlaçamento paradoxal. Logo de início, a fala supõe uma certa situação de enunciação que, na realidade, vai sendo validada progressivamente por intermédio da própria enunciação. Desse modo, a cenografia é ao mesmo tempo a fonte do discurso e aquilo que ele engendra; ela legitima um enunciado que, por sua vez, deve legitimá-la, estabelecendo que essa cenografia onde nasce a fala é precisamente $a$ cenografia exigida para enunciar como convém, segundo o caso, a política, a filosofia, a ciência, ou para promover certa mercadoria. (MAINGUENEAU, 2001, p. 87, grifos do próprio autor.).

Lançando mão da morfologia da palavra cenografia, Maingueneau (2006, p. 252253) argumenta que à dimensão teatral contida em "cena" é acrescentada a dimensão da grafia, não como uma oposição entre suporte oral e gráfico, mas sim como um processo fundador, de inscrição que legitima um texto "em sua dupla relação com a memória de enunciação que se situa na filiação de outras enunciações e que reivindica um certo tipo de reemprego". É como se a cenografia descrevesse um círculo que instaura e valida o enunciador, o co-enunciador, o lugar (topografia) e o momento (cronografia) a partir dos quais uma enunciação se desenvolve.

Nem todos os gêneros discursivos, porém, possibilitam que se suscite uma cenografia em seu uso. Muitos, como um cadastro de clientes ou os textos legais, mantêm-se em sua cena genérica. Já outros, como uma publicidade e também as tiras cômicas, nosso objeto de estudo, permitem, dentro de suas coerções genéricas, diferentes cenografias.

Maingueneau destaca que no caso dos gêneros escritos que permitem lançar mão de diferentes cenografias em sua atualização, é por meio dela que o leitor entra em contato com o texto, suas cenas genérica e englobante são relegadas a segundo plano, apanhando o leitor em uma espécie de armadilha. Porém não é esperado que uma cenografia se explicite a si mesma, "a cenografia se mostra, por definição, para além de toda cena de fala que seja dita no texto" (idem). Podemos identificá-la a partir de (i) marcas textuais; (ii) indicações no paratexto, como um prefácio, um título e (iii) por menções explícitas que reivindicam o aval de cenas pré-existentes - de obras literárias, de 
interações cotidianas, ou de eventos de fala como I have a dream de Marthin Luther King.

Maingueneau entende esse encaixamento como um procedimento para legitimar o quadro de uma enunciação, e designa como cena validada a cena de fala que servirá de caução à cenografia construída. São cenas já instaladas no universo de saber e de valores do público (idem p. 256) nas quais uma cenografia pode se apoiar para que seja levado a cabo o projeto de dizer do locutor. Segundo o próprio autor, o repertório das cenas validadas:

varia em função do grupo visado pelo discurso, mas, de modo geral, a qualquer público, por vasto e heterogêneo que seja, pode-se associar um estoque de cenas que podemos considerar como compartilhadas. A "cena validada" se apoia em um estereótipo descontextualizado, popularizado pela mídia. Produz-se no discurso uma interação entre cenografia e cena validada (...)" (MAINGUENEAU, 2008, p.127)

Com o acréscimo eventual da cena validada, temos então quatro dimensões atuando na cena da enunciação de um gênero discursivo. Para ilustrar o funcionamento dessas quatro cenas em um texto concreto, repetiremos um exemplo usado pelo próprio autor. Em outra obra em que aborda o mesmo tema, Maingueneau (2001, p. 91-92) cita uma carta usada na campanha de François Miterrand em sua reeleição a presidente da França em 1988. Em lugar de um programa eleitoral, os franceses receberam a reprodução de uma carta - com elementos gráficos como partes manuscritas, traço vertical marcando a margem como se fosse a folha de um caderno - firmada pelo candidato. Nela, Miterrand se dirigia aos franceses como "meus caros compatriotas", apresentava as razões para postular a reeleição e o fazia evocando em um determinado momento do texto uma “espécie de reflexão em comum, como acontece quando a família se reúne à noite, em volta da mesa" (idem). Descrevendo a cena da enunciação desse texto, Maingueneau aponta que temos como cena englobante, o discurso político, com os parceiros reunidos no espaço-tempo de uma eleição. A cena genérica é a das publicações usadas para os candidatos apresentarem seu programa aos eleitores. E a cenografia é a da correspondência particular, que coloca em contato dois indivíduos que mantêm uma relação pessoal. Nessa cenografia, é evocada ainda a conversa entre os membros da família à noite, ao redor da mesa. O leitor se vê convidado a participar, como se fosse um filho, de uma cena em que o presidente estaria implicitamente assumindo o papel de pai. Conforme o autor (idem), a cena da conversa ao redor da mesa entre os membros de uma família é a cena validada, uma cena instalada na memória coletiva dos franceses como 
algo positivo. Temos assim, uma articulação entre todas as dimensões da cena da enunciação em que vemos acionados uma série de recursos que contribuem para o que identificamos como a finalidade última da Carta, convencer o eleitor a apoiar a candidatura de Miterrand.

Como podemos ver, ao descrever o funcionamento da cena validada, Maingueneau faz uso de dois outros conceitos, estereótipo e memória coletiva os quais, por sua abrangência, delimitaremos aqui minimamente como foram compreendidos e mobilizados em nosso trabalho.

\section{Estereótipo e memória}

Como se sabe, o termo estereótipo provém das artes gráficas, a estereotipia consiste em uma técnica de impressão a partir de uma chapa que permite a reprodução massiva de conteúdos. Daí passou a ser usado de forma metafórica para referir-se a algo fixo, rígido (MUSSALIM e FONSECA-SILVA, 2011, p. 140).

No uso cotidiano, não especializado, o termo estereótipo normalmente está associado ao preconceito e, como tal, visto de forma negativa como fonte dos mais variados tipos de discriminação. No campo do conhecimento especializado, no entanto, ele é um objeto estudado transversalmente em diferentes âmbitos das ciências humanas e nem sempre visto como essencialmente negativo. É o que comprovam Amossy e Pierrot (2001) em uma obra referencial sobre o tema na qual abordam como esse conceito, e também o de clichê, foram estudados por diferentes áreas das ciências sociais, dos estudos literários e da linguagem.

Ao acompanhar como a noção foi abordada por esses distintos olhares, constatamos que as reflexões sobre o conceito de estereótipo podem revelar seus aspectos construtivos e de produtividade. Conforme destacam as autoras, essas reflexões permitem "estudiar las interacciones sociales, la relación de los discursos con los imaginarios sociales y, en términos más amplios, la relación entre el lenguaje y la sociedad" (idem, p. 11).

$\mathrm{Na}$ obra mencionada, as autoras citam que o publicitário estadunidense Walter Lippmann em 1922 foi o primeiro a introduzir o termo nas ciências sociais ao publicar a obra A Opinião Pública. Nela define os estereótipos como imagens mentais que medeiam nossa relação com a realidade, representações cristalizadas, esquemas culturais préexistentes mediante os quais filtramos a realidade que nos circunda. Segundo Amossy e 
Pierrot (2001), Lippman considera que essas imagens são indispensáveis para a vida em sociedade, posto que seria esgotador se tivéssemos que interagir com a realidade sem esse processo mental que possibilita categorizá-la e identificá-la com algo familiar, muito embora, como bem sinalizam as autoras, essas imagens mentais sejam fictícias, não porque sejam mentirosas, mas porque expressam um imaginário social.

Em um artigo em que também mobilizam o conceito, Fonseca-Silva e Mussalim (2011) comentam que a esse trabalho pioneiro de Lippman se seguiram muitos outros, a maioria tratando de apontar o reducionismo e a nocividade presentes no estereótipo associando-o a diversos comportamentos autoritários e intolerantes. Conforme as autoras, o conceito só será reabilitado a partir dos anos 50 com diferentes autores que, como Lippmann, veem no estereótipo aspectos positivos, identificados como funções cognitivas e sociais e o integram a um

modelo explicativo das relações intergrupais, com o objetivo de facilitar a compreensão dos acontecimentos sociais complexos, justificar as ações coletivas dirigidas a determinados grupos sociais e criar ou manter diferenciações valorizadas positivamente de um grupo em relação a outro (op.cit, p. 140).

Voltando a Amossy e Pierrot (2001, p. 34), as autoras destacam que, apesar da reavaliação por que passou a noção de estereótipo, a apreciação negativa nunca substituiu completamente a positiva, o que lhes permite entendê-lo, retomando Amossy (1991) como um conceito com uma bivalência constitutiva no pensamento contemporâneo.

Coincidimos com as autoras em que, seja vista de forma neutra, seja em sentido pejorativo, é importante destacar a pertinência da noção de estereótipo para fazer frente à questão das mediações sociais e a comunicação. Para os pesquisadores que trabalhamos com o discurso, trata-se de uma noção que se revela bastante operacional, posto que, a partir dela, podemos abordar também os aspectos não verbais da comunicação, que não são contemplados em noções como o pré-construído ${ }^{17}$ de Pêcheux, por exemplo.

Assim, em uma perspectiva que não vê o estereótipo como algo intrinsecamente negativo, adotaremos em nosso trabalho a definição proposta por Amossy (1991) e Amossy-Pierrot (2001), que vemos como bastante semelhante àquela proposta por Lippman. Entendemos, portanto, os estereótipos como representações culturais pré-

\footnotetext{
${ }^{17}$ Conforme Charaudeau e Maingueneau (2004, p. 401) essa noção pode ser entendida como uma "marca, no enunciado, de um discurso anterior" que "se opõe àquilo que é construído no momento da enunciação". Trata-se de um efeito discursivo especialmente observável em operações de encaixamento sintático, como as relativas, as nominalizações, os adjetivos deslocados etc.
} 
existentes, esquemas coletivos cristalizados e compartilhados socialmente, que medeiam nossa relação com o real. São elementos que contribuem para a construção do sentido em diferentes níveis, tanto verbais como não verbais, que organizam as representações coletivas e o imaginário social. Acrescentamos ainda que tal como Mussalim e FonsecaSilva (2011), entendemos que os estereótipos possibilitam a inscrição do social e do histórico no texto.

Nesse processo, não podemos deixar de mencionar o papel da memória, tanto em sua dimensão cognitiva individual como no sentido de uma memória de saberes compartilhados, uma memória coletiva, aspecto que aqui nos interessa especialmente. Maingueneau e Charaudeau (2008, p. 325) destacam que o discurso se relaciona com a memória em dois planos complementares: o da textualidade e o da história. $\mathrm{Na}$ textualidade, a memória está associada ao processamento de um texto, a mecanismos de coesão como a anáfora, os conectores, as pressuposições. Já na sua dimensão histórica, a memória se associa ao interdiscurso, aqui entendido como "o conjunto das unidades discursivas (que pertencem a discursos anteriores do mesmo gênero, de discursos contemporâneos de outros gêneros etc) com os quais um discurso particular entre em relação implícita ou explícita" (idem, p. 286). A pesquisadora francesa Sophie Moirand (1999 apud CHARAUDEAU e MAINGUENEAU, 2008, p. 325) vincula essa noção ao dialogismo de Bakhtin e destaca que na mídia e pela mídia efetua-se um trabalho de constituição de uma memória interdiscursiva. Essa vinculação nos parece importante porque explicita a pertinência de nos alinharmos com essa perspectiva em nosso trabalho, visto que, como afirmado no início deste capítulo, o dialogismo bakhtiniano é um dos fundamentos de nossa visão a respeito da linguagem. Retomando Bakhtin, reiteramos que nunca enunciamos adamicamente, de que nossos enunciados são sempre elos na complexa cadeia que representam os outros enunciados, não importa de que tipo sejam.

\section{A noção de ethos}

O conceito de ethos é originário da Retórica clássica, atribui-se a Aristóteles a primeira elaboração conceitual a esse respeito, e refere-se à imagem que um locutor, pelo ato de tomar a palavra, constrói de si para seus destinatários. Como afirma Amossy (2005, p.9), "seu estilo, suas competências linguísticas e enciclopédias, suas crenças implícitas são suficientes para construir uma representação de sua pessoa" sem que para isso seja necessário que ele enumere suas qualidades, faça seu autorretrato ou fale 
explicitamente de si. A autora destaca que seja ou não de forma consciente e intencional, toda troca verbal implica uma apresentação de si para o outro e vice-versa. A noção foi retomada no âmbito da Pragmática e da Análise do Discurso e desperta hoje um interesse crescente nos mais diversos campos dos estudos da comunicação. No entender de Maingueneau (2008c, p. 55), esse interesse se deve "à evolução das condições do exercício da palavra publicamente proferida, particularmente com a pressão das mídias audiovisuais e da publicidade".

Maingueneau desenvolve uma delimitação do conceito de ethos no quadro da Análise do Discurso e para tanto parte de algumas das ideias, designadas por ele como linhas de força da noção de ethos tal como concebida por Aristóteles. São elas:

- o ethos é uma noção discursiva; ele se constitui por meio do discurso, não é uma "imagem" do locutor exterior à fala;

- o ethos é fundamentalmente um processo interativo de influência sobre o outro;

- o ethos é uma noção fundamentalmente híbrida (sociodiscursiva), um comportamento socialmente avaliado, que não pode ser apreendido fora de uma situação de comunicação precisa, ela própria integrada a um conjuntura sócio-histórica determinada. (op. cit. p.63)

A perspectiva de Maingueneau vai além da persuasão pelos argumentos, a noção de ethos para ele permite refletir sobre o processo mais amplo da adesão dos sujeitos a determinado posicionamento. Para exemplificar, o autor cita que, diferentemente do que acontece com os chamados por ele de gêneros "funcionais" - formulários administrativos ou outros gêneros instrucionais -, os gêneros do discurso político, publicitário, filosófico devem ganhar um público que está no direito de ignorá-los ou recusá-los. O que também é válido no caso que nos concerne, visto que gêneros que pertencem ao tipo de discurso humorístico necessitam mais que persuadir o interlocutor, precisam de sua adesão e engajamento para que o ato humorístico tenha o efeito esperado, ou seja, cause graça. $\mathrm{O}$ interlocutor pode, inclusive, não achar graça, mesmo entendendo o ato humorístico.

Enquanto na sua origem na Antiguidade a noção de ethos estava essencialmente ligada à oralidade, na proposta de Maingueneau ela é ampliada também para os textos escritos. Conforme o autor, todo texto escrito, ainda que o negue, possui uma "vocalidade" (grifos no original) específica que possibilita relacioná-lo com uma caracterização do corpo do enunciador (que não deve ser confundido com o corpo do locutor extradiscursivo) “a um 'fiador' que, por meio de seu 'tom' atesta o que é dito” (p. 64). Essa concepção mais 'encarnada' do ethos recobre portanto 
não só a dimensão verbal, mas também o conjunto de determinações físicas e psíquicas associadas ao "fiador" pelas representações coletivas. Assim, acaba-se por atribuir ao fiador um "caráter" e uma "corporalidade", cujo grau de precisão varia segundo os textos. O "caráter" corresponde a um feixe de traços psicológicos. Quanto à "corporalidade", ela é associada a uma compleição física e a uma forma de se vestir. Além disso, o ethos implica uma forma de mover-se no espaço social, uma disciplina tácita do corpo, apreendida por meio de um comportamento. O destinatário o identifica apoiando-se num conjunto difuso de representações sociais avaliadas positiva ou negativamente, de estereótipos que a enunciação contribui para reforçar ou transformar (Ibid., p. 65).

Como se vê, a noção de ethos discursivo se relaciona diretamente com a de estereótipo. Será a partir do estereótipo que o interlocutor acionará esquemas mentais e representações cristalizadas que o conduzirão à construção da corporalidade e do caráter do fiador. No caso das tiras cômicas, como se trata de um gênero em que estão envolvidas duas semioses, imagem e texto verbal interagirão nesse processo. Pensemos, por exemplo na imagem do personagem Geraldão, criação do cartunista Glauco e reproduzido na figura abaixo.

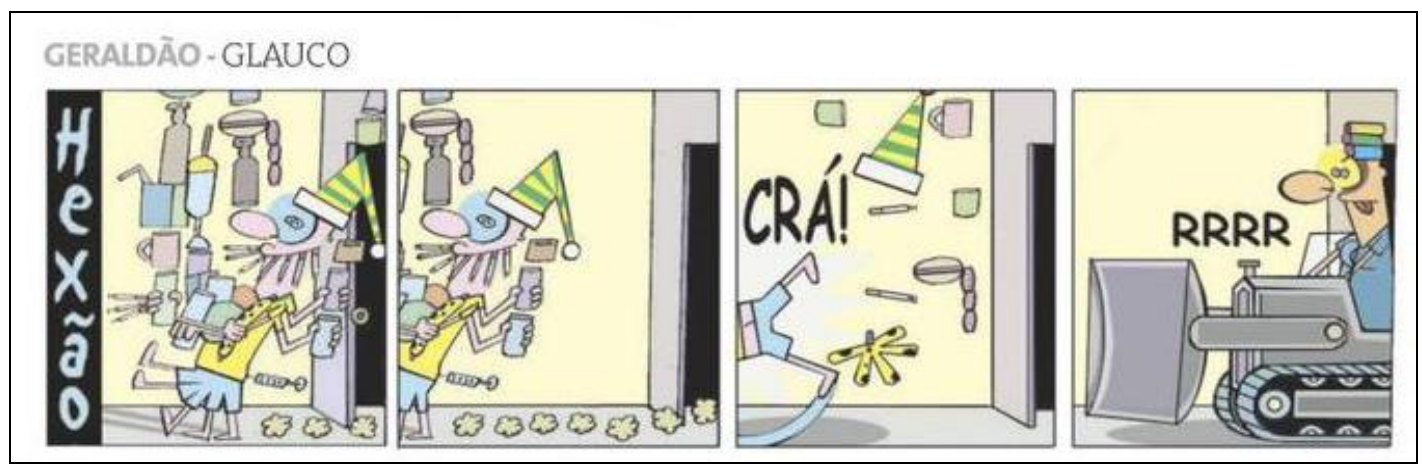

Figura 1 - Geraldão de Glauco - Fonte: Folha de S.Paulo - 18/06/2006.

O personagem normalmente é desenhado com uma quantidade superlativa de elementos. Os vários braços, pernas, copos de bebida, cigarros, seringa, alimentos, os olhos arregalados etc. colaboram para caracterizar sua compulsividade e falta de qualquer tipo de limite nas atitudes.

Gatti (2013), em trabalho sobre o estereótipo da criança em tiras cômicas, valeu-se também da mesma noção na análise dos personagens infantis. Ele chama a atenção para o fato de que no processo de identificação de um ethos discursivo específico para os 
personagens de tiras cômicas a questão da longevidade e da dispersão temporal das produções adquire relevância. Em suas palavras:

quando falamos da personagem Mafalda, fatalmente a associamos com imagens muito específicas: a menina sagaz, inteligente, contestadora, etc. e jamais a associamos com traços como futilidade ou idiotice. Isso é, obviamente, decorrência do discurso e do ethos que eles implicam de Mafalda nas tiras que ela protagoniza, dispersas ao longo do tempo em que foram publicadas. Em outras tiras, a questão do ethos é tão predominante que decorre dele todo o efeito de humor. É o caso, por exemplo, das tiras protagonizadas pelo personagem Cascão da Turma da Mônica, cujo humor releva constantemente de sua falta de higiene e de seu asco à agua (GATTI, 2013, p. 144).

Não só concordamos com Gatti, como o apontado por ele se aplica também ao nosso caso pois várias das tiras com as quais trabalhamos têm personagens fixos e longevos. Em nossa análise, mobilizaremos o conceito com relação às diferentes vozes e instâncias enunciativas presentes nas tiras cômicas.

\section{Particitação e hiperenunciador}

$\mathrm{Na}$ análise, nos valemos ainda de duas outras noções propostas por Maingueneau (2008b, 2014), a saber, hiperenunciador e particitação. Conforme o autor (2014, p.69 e seguintes), tem-se um hiperenunciador em vários tipos de citação em que não se especifica o autor. Maingueneau caracteriza essas citações como particitações, uma palavra-valise em que se combinam participação e citação. No sistema de particitação:

- o enunciado citado é autônomo e memorizável, ou porque em sua natureza era assim ou porque foi destacado de um texto ${ }^{18}$;

- o enunciado precisa ser reconhecido como citação pelos destinatários, sem que sua fonte seja indicada pelo locutor citante e inclusive sem que ele indique estar fazendo uma citação, com uso de um verbo dicendi ou de um inciso, por exemplo;

- o enunciado faz parte de um thesaurus verbal cujos contornos são vagos, indissociável de uma comunidade que se define justamente por partilhar referido thesaurus. O locutor citante, por sua enunciação, pressupõe pragmaticamente que ele mesmo e seu alocutário são membros dessa comunidade. Tem-se então uma relação de tipo especular: o locutor cita aquilo que poderia/deveria ser dito pelo alocutário ou por

\footnotetext{
${ }^{18}$ Maingueneau (2010, p. 13) distingue dois regimes distintos de enunciação: a textualizante e a aforizante. Esta última produziria enunciados que são "destacados por natureza" e outros que são "destacados de um texto".
} 
qualquer membro da comunidade que age em total conformidade com esse pertencimento.

- esse thesauros e a correspondente comunidade implicam um hiperenunciador, uma instância não nomeada, um sujeito universal, que lhes confere sua unidade e cuja autoridade garante não exatamente a verdade do enunciado, mas, sim, sua validade, adequação aos valores, aos fundamentos de uma coletividade.

A partir do que têm de afinidades em seu funcionamento pragmático, Maingueneau (2008b, p. 103 e seguintes) distingue o que ele chama de famílias de particitações. Destacaremos aquelas que são mais relevantes para o nosso trabalho.

O primeiro grupo é chamado por ele de particitações sentenciosas, pertencem a esse grupo os provérbios e o adágio jurídico. A principal diferença entre eles seria ter ou não uma fonte definida, diferença que na verdade é secundária, conforme o próprio autor.

Em ambos os casos o enunciador invoca um hiperenunciador que vem a ser uma sabedoria ancestral, no caso dos provérbios, ou o Direito, no caso dos adágios jurídicos. Instância essa que é reconhecida pelos interlocutores, membros da mesma comunidade de experiência, da mesma tradição. A diferença entre elas é que no primeiro caso é uma comunidade de ordem natural e no segundo, profissional.

O segundo grupo da classificação proposta por Maingueneau que abordaremos são as particicitações de grupo, delas destacaremos as particitações militantes. Conforme o autor, elas permitem reforçar a coesão de uma coletividade frente a um exterior que representa uma ameaça. São exemplos de particitações militantes os cantos de torcida, os slogans militantes, os gritos de guerra. Caracterizam-se também por serem produzidas por um enunciador coletivo, que Maingueneau distingue em três níveis distintos:

(a) os locutores empíricos, os indivíduos que compõem o grupo, e que não representam interesse à análise do discurso;

(b) o ator coletivo do qual esses locutores participam, ou seja, um partido, um conjunto de manifestantes, uma torcida;

(c) o hiperenunciador que funda os diversos pontos de vista que esse ator expressa, como por exemplo (aspas do autor): “a Esquerda”, “a Nação”, “o Clube" etc.

O autor acrescenta que, enquanto o referente de (b) são grupos de locutores que formam uma organização em um dado momento e lugar, (c) tem por referente entidades que ele classifica como transcendentes em certa medida. 
Dentro das particitações militantes às quais Maingueneau dedica especial atenção, destacamos o slogan militante e o grito de torcida, por sua presença em nosso corpus.

\subsection{O slogan militante}

O slogan militante se caracteriza por ser duplamente repetível, além de verbalizado indefinidamente, reclama um lugar de particitação, como cartazes. Além disso, implica um ethos apropriado, marca um empenho total da pessoa em torno da causa que defende pois a enunciação de um slogan militante implica a existência de um exterior hostil ou indiferente frente ao qual o grupo se afirma.

Valendo-se da classificação do semanticista Cruse (1986), Maingueneau (2008b) afirma que, nas particitações dos slogans militantes, tem-se coletivos cuja permanência é assegurada, no tempo, por "grupos", ou seja, coletividades humanas consolidadas por uma finalidade comum, tais como uma equipe, uma empresa, um auditório. Esses grupos, por sua vez, podem ser estáveis ou transitórios. No caso de grupos militantes, podemos tê-los das duas formas. Os estáveis "são comunidades pré-construídas, anteriores à enunciação, isto é, grupos ligados a um aparelho e dotados de uma memória compartilhada". Já os grupos transitórios configuram-se como comunidades "hic et nunc que a enunciação do slogan tem exatamente a função de unir". Como exemplo, o autor cita uma manifestação que reúne uma população heterogêna em torno a uma questão atual, em suas palavras "o slogan não tem outra comunidade-suporte senão o próprio grupo que o está enunciando".

Os slogans militantes implicam um hiperenunciador cuja autoridade institui o conjunto de slogans compatíveis no espaço da manifestação e varia em função da opção política dos agrupamentos.

\subsection{Os cantos de torcida}

Os cantos de torcida, especialmente no caso da Argentina (cf. GANDARA, 1997), fazem parte do patrimônio do grupo, constituem-se como marcas que corroboram o pertencimento a esse grupo. Maingueneau (idem) destaca que diferentemente dos slogans políticos, em que uma boa parte deles se renova para permanecerem ativos e em contato direto com uma dada conjuntura, os gritos de torcida salientam acima de tudo uma lógica 
de tradição, de repetição ritual, que conduz à estabilização. Normalmente põem em evidência a exclusão do adversário e reafirmam o pertencimento dos locutores ao grupo.

Como veremos na análise, a conceituação e classificação apresentada revelou-se muito produtiva na interpretação de alguns dos enunciados encontrados em nosso corpus.

Concluída a apresentação dos principais conceitos que fundamentam nosso trabalho do ponto de vista linguístico-discursivo, no próximo capítulo nos dedicaremos a refletir sobre um dos aspectos constitutivos do gênero com que trabalhamos: o humor. 


\section{CAPÍTULO 2 - Sobre o humor}

\section{Introdução}

Falar de humor é entrar em um terreno com inúmeras trilhas abertas e marcado por muitas pegadas. Desde a antiguidade clássica até os tempos atuais, nomes pertencentes aos mais diferentes campos do conhecimento dedicaram-se a refletir sobre o humor e outros conceitos correlatos, como o cômico e o riso. Luiz Carlos Travaglia, um dos primeiros a defender as pesquisas sobre o humor no campo da Linguística no Brasil ${ }^{19}$, em artigo publicado em 1990 identificava no estudo do humor pelas diferentes disciplinas do conhecimento, além da abordagem linguística, a histórica, a antropológica, a comunicacional, a semiológica, a sociológica e a psicológica.

As conceituações, categorizações e recortes por vezes redundam em dificuldade quanto a termos a serem usados: cômico, humorístico, risível? Entre os autores que consultamos Charaudeau (2006, p. 20), Brait (1996, p. 58) e Minois (2015) reportam esse aspecto. Minois (op. cit. p. 20) chega a classificar de ubuescos os debates registrados entre especialistas a respeito da própria palavra humor. De nossa parte, entendemos que a especificação responde aos objetivos de cada estudo. No nosso caso, seria dispendioso e infrutífero nos dedicarmos a detalhar cada conceituação ou a advogar a favor de uma posição ou outra. Assim, esclarecemos que neste trabalho usamos a palavra humor de forma ampla, como uma noção geral que compreende o cômico, o risível, a ironia, o sarcasmo, a paródia e outros conceitos assemelhados. Outro ponto importante a esclarecer é que nosso foco é no humor, e não no riso. O riso é uma resposta fisiológica que pode ou não decorrer de um ato de humor.

Esgotar o assunto é impossível e foge de nosso objetivo um exame detalhado de cada um dos aportes. Assim, tendo em vista o já exposto, neste capítulo situaremos as diferentes abordagens do humor na história do pensamento ocidental para depois descrever a proposta que usaremos para analisar o humor nas tiras cômicas, a saber, as reflexões e as categorias elaboradas por Charaudeau (2006).

Começaremos situando o humor em uma perspectiva filosófica contemporânea a partir do autor francês Gilles Lipovetsky (2005).

\footnotetext{
${ }^{19}$ Em Carmelino e Ramos (2015) encontra-se uma síntese bastante atualizada e abrangente a respeito do estado da arte no que se refere ao humor como objeto de estudo na Linguística no Brasil.
} 


\section{Uma sociedade humorística?}

O filósofo francês Gilles Lipovetsky na obra A Era do Vazio (2005), publicada originalmente em francês em 1983, apresentava as características de uma, naquele momento, nova época que seria conhecida por pós-modernidade. Um dos capítulos dessa obra se chamava A sociedade humorística e nele o autor defendia a proposta embutida no título. Segundo ele, apesar de o cômico estar presente em todas as culturas, inclusive nas selvagens,

apenas a sociedade pós-moderna pode ser chamada humorística, apenas ela se instituiu globalmente sob a égide de um processo que tende a dissolver a oposição, até agora estrita, entre o sério e o não-sério; a exemplo de outras grandes divisões, a divisão entre o cômico e cerimonioso se dilui, beneficiando um clima largamente humorístico. Desde a era clássica, a partir da instituição das sociedades estatais, o cômico se opõe às normas sérias, ao sagrado e ao Estado por representar uma espécie de um segundo mundo carnavalesco e popular na Idade Média, o mundo da liberdade satírica do espírito subjetivo. Hoje em dia essa dualidade tende a se liquefazer sob a força invasora do fenômeno humorístico que anexa todas as esferas da vida social, mesmo que seja contra a nossa vontade (idem, p. 112).

Para elucidar um pouco mais a extinção do limite entre o sério e não-sério que, segundo ele, caracteriza nosso tempo, o autor retoma historicamente as características que marcaram a presença do riso na história da sociedade ocidental. Reverberando as propostas contidas no consagrado estudo de Bakhtin sobre o cômico e o grotesco a partir da obra de François Rabelais ${ }^{20}$, Lipovetsky (2005, pp. 112 a 115) identifica três fases na história do cômico.

Na Idade Média, a cultura cômica se apresentava profundamente ligada às festas, às comemorações carnavalescas - que chegavam a durar três meses por ano. Nesses momentos, tudo o que era ligado ao poder, ao sublime e ao sagrado era rebaixado. $\mathrm{O}$ riso se dava essencialmente a partir de grosserias, da ridicularização pelo grotesco cujos alvos eram especialmente os cultos religiosos, as coroações.

$\mathrm{Na}$ Idade Clássica, emergem novos gêneros de literatura cômica, satírica e divertida que se distanciam da tradição grotesca. O riso, conforme o autor, é expurgado das grosserias e exageros bufos baseados em obscenidades e escatologia para reduzir-se ao espírito, à ironia pura exercida às custas de costumes e individualidades. Dessa forma, o cômico na comédia clássica, na fábula, na caricatura e no vaudeville torna-se crítico

\footnotetext{
${ }^{20}$ Bakhtin, Mikhail. A Cultura Popular na Idade Média e no Renascimento: o contexto de François Rabelais. Tradução de Yara Frateschi Vieira. São Paulo: Hucitec; Brasília: Editora da UnB, 1987.
} 
(grifo do autor). Ademais, entra em uma fase de dessocialização, devido ao empobrecimento do mundo carnavalesco, o que tira do cômico seu caráter de público e coletivo, ele é privatizado tornando-se "civilizado" e aleatório.

Ao mesmo tempo em que se privatiza, o riso se disciplina: é preciso compreender o desenvolvimento dessas formas modernas do riso, que são o humor, a ironia e o sarcasmo, como um tipo de controle cuidadoso e infinitesimal exercido sobre as manifestações do corpo, nisso análogo ao adestramento disciplinar analisado por Foucault. (...) no século XVIII, o riso alegre se torna um comportamento desprezado e vil que, até o século XIX, foi considerado vulgar, inconveniente e até mesmo perigoso e tolo, por encorajar a superficialidade, pior, a obscenidade. (p.115)

Chegamos por fim à Pós-modernidade, aquela classificada por Lipovetsky como a sociedade humorística. Segundo o autor, nela o humor se caracteriza pelo hedonismo, é regido pelo princípio do prazer. Para ele, o tom dominante na publicidade, na moda, nos gadgets, nos quadrinhos não é satírico ou caricatural, mas sim, lúdico. O humor positivo e desenvolto teria substituído o escárnio na denúncia de uma sociedade fundamentada em valores reconhecidos.

O humor na publicidade ou na moda não tem vítima, não zomba, não critica, limitando-se apenas a prodigalizar uma atmosfera eufórica de bom humor e de felicidade sem avesso. $O$ humor de massa não mais repousa sobre um fundo de amargura ou de tristeza: longe de mascarar um pessimismo e de ser a polidez do desespero, o humor contemporâneo não deseja ser profundo e descreve um universo radioso. (pp. 115)

O historiador francês Georges Minois (2015, p. 18), comentando Lipovetsky, diz que vivemos atualmente em uma sociedade que quer ser cool e fun "agradablemente jovial, en la que los medios difunden modelos desenfadados, héroes rebosantes de humor, y en la que tomarse las cosas en serio no está bien visto”.

Além do hedonismo, da onipresença e da ausência superficial da angústia, Lipovetsky aponta também a autorreferencialidade como característica do humor pósmoderno: "o eu se torna um alvo privilegiado do humor, objeto de zombaria e de autodepreciação" (p. 119).

A leitura das ideias de Lipovetsky mais de trinta anos após sua publicação original, tendo em conta nosso lugar social de fala e de escrita e depois de termos testemunhado vaivéns na ordem política e social do mundo que talvez jamais tivéramos sonhado, nos faz colocar em perspectiva suas generalizações. Parece-nos que continua vigente sua percepção de que o código do humor ocupa um lugar significativo na 
sociedade ocidental contemporânea, considerando sua presença em uma enorme variedade de práticas e circunstâncias, não mais atreladas a momentos e lugares específicos, por outro lado não nos parece que se possa homogeneizar suas características como o autor o faz. Se na publicidade ou nas apresentações de stand up a tônica pode ser o lúdico pelo hedonismo, em outros campos e práticas também podemos encontrar o humor à serviço da criticidade e inclusive de denúncia. Por outro lado, o humor também estar a serviço de disseminar preconceitos e naturalizar práticas autoritárias e inclusive repressivas.

No primeiro caso, o humor usado com fim de crítica e denúncia, encontramos, por exemplo, o estudo realizado por Vivero García (2011) sobre slogans presentes nas manifestações ocorridas na Espanha em 15 de maio de 2011 no movimento que ficou conhecido como Movimiento 15-M ou Indignados, que tinham como objetivo reivindicar maior participação nas decisões políticas, econômicas e sociais que penalizavam a população com inúmero cortes orçamentários. Nas conclusões de sua análise, a autora destaca que

el humor y el placer que genera tienen un importante papel en momento de resistencia a la lógica del beneficio económico y permite combatir el sentimiento de impotencia ante el rodillo neoliberal y ante el conformismo social alimentado por el discurso dominante (op. cit. p.115).

Essa visão é compartilhada pelo professor Elias Thomé Saliba (NATARELLI, 2010) quem entende que o riso pode também ser a arma social dos impotentes. Segundo ele, ao longo da história o riso popular permitiu a criação de uma " cultura da divergência, ativa e oculta - mostrando como o humor se tornou uma arma política importante contra os regimes repressivos". Como não se pode mudar a história real, muda-se o sentido dela pois o riso, a piada são, em sua essência, alteração de sentido, reversão de significado.

Já a historiadora argentina Florencia Levín (2012, p. 216), analisando produções do humor gráfico do jornal Clarín entre 1973 e 1985, para examinar as atitudes sociais dos humoristas com relação ao regime militar, chegou a conclusões que apontam para um sentido oposto no que se refere à violência de Estado, praticada de forma sistemática pelos representantes do regime. Segundo ela,

la tematización e interpretación del fenómeno de la violencia por parte de los humoristas puede cumplir funciones diversas que tienden tanto a la crítica como, al mismo tiempo, a cierta banalización, trivialización y, por lo tanto, naturalización de la problemática. 


\section{As teorias sobre o humor}

Attardo (1994, p.47 e seguintes) aponta que uma classificação bastante difundida nos diferentes é a que divide os diferentes estudos sobre o humor em três grandes grupos, a saber, teorias da superioridade, do alívio e da incongruência, às quais o autor relaciona as abordagens social, psicanalítica e cognitiva, respectivamente. Complementamos com Ruiz Gurillo (2012, p.16), quem em uma breve síntese sobre as abordagens teóricas do humor assinala que teorias da superioridade, a experiência humorística é vista como uma manifestação do sentimento de superioridade do homem para com o homem; para as teorias do alívio, o humor é o efeito de aliviar algum tipo de energia acumulada e o riso seria fonte de prazer; para as teorias da incongruência o humor se baseia na descoberta de uma realidade ou de um pensamento incongruente com aquilo que era esperado, há portanto uma quebra de expectativa também.

Entre os nomes associados às teorias da superioridade do humor, Attardo (idem) menciona Hobbes e Bergson, porém adverte que Platão e Aristóteles, como os primeiros nomes a pensar algo sobre o humor, já haviam apontado que ele tem um elemento negativo, um lado agressivo e que essa ideia teve grande influência na sua percepção em nossa cultura. $\mathrm{O}$ autor cita que para Thomas Hobbes o riso provém de um senso de superioridade de quem ri com relação a algum objeto. Quanto a Bergson, Attardo o vê como o mais influente entre aqueles que desenvolveram reflexões sobre o humor como superioridade. Para o filósofo francês, o humor é um corretivo social, ou seja, é usado pela sociedade para corrigir comportamentos desviantes. Por outro lado, Bergson em certa medida também viu a incongruência como fonte de humor. Em seu livro Le rire, publicado pela primeira vez na França em 1900, o autor desenvolve os conceitos "interferência de séries" e "transferência" como mecanismos para lograr o humor. Segundo ele, "la interferencia de dos sistemas de ideas en la misma frase es fuente inagotable de efectos cómicos. Hay muchos medios de obtener esta interferencia, es decir, de dar a una misma frase dos significaciones independientes que se superponen" (Bergson [1900] 2009, p. 89). Brait (1996, p. 36), em trabalho sobre a ironia, diz que Bergson, ao propor esses conceitos, se torna um dos primeiros a trazer para as reflexões sobre o humor um ponto de vista linguístico-discursivo.

Na abordagem psicanalítica, que vê o humor como alívio, o principal nome é Freud ([1905]). Em seus estudos sobre o risível, Freud faz uma divisão entre três domínios: o chiste, o cômico e o humor. Steimberg (2001, p. 2, grifos nossos) em síntese 
sobre a classificação freudiana aponta que cômico implica uma justaposição de sentidos divergentes em eventos que podem ou não incluir uma ação consciente do sujeito. Como exemplo, cita o riso diante de alguém sério e formal que escorrega em uma casca de banana. No âmbito do cômico, Freud situa também objetos lúdicos, divertidos. Na percepção do cômico, o prazer advém de uma economia na despesa com a representação e da satisfação de uma pulsão agressiva que põe em cena um sentimento de superioridade. Nos chistes, o risível está depositado sobre um terceiro. O prazer, nesse caso provém da economia de energia resultante da superação compartilhada da inibição da agressão. Na narração de um chiste, está implicado um receptor que é convidado a essa agressão comum. No humor, por sua vez,

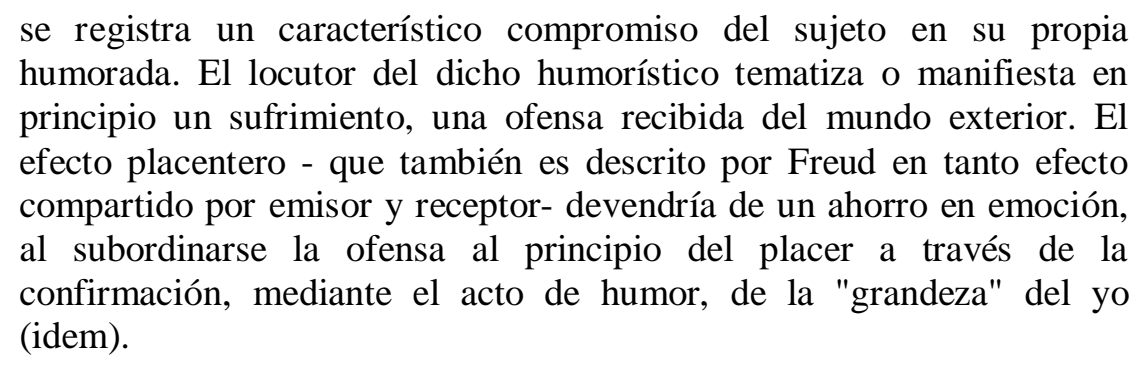

Acrescentamos que Morais (2008) a esse mesmo respeito elucida que "o chiste é da ordem do simbólico, o cômico, da ordem do imaginário e o humor, da ordem do real". Seja proveniente de qualquer uma das formas apontadas anteriormente, o riso, para Freud, funciona como liberação de impulsos socialmente proibidos ou reprimidos, como a violência, a sexualidade ou também o lúdico.

No âmbito das teorias do humor como incongruência, Attardo (1994 p. 48) cita que os primeiros autores cujas reflexões se encaminham nessa direção são Kant, para quem o riso era o resultado do rompimento inesperado de uma expectativa, e Schopenhauer, quem via o riso como o resultado de percebermos a incongruência entre os objetos reais e os conceitos relacionados a esse objeto.

Passando ao campo da Linguística, entre os principais teóricos que desenvolveram propostas com base na incongruência estão Victor Raskin e Salvatore Attardo. O primeiro propôs em 1985 um modelo próprio denominado Semantic Script Theory of Humor (SSTH), mais conhecida como Teoria dos Scripts. Essa teoria foi posteriormente reformulada, em 1991, em parceria com Attardo, para a General Theory of Verbal Humor $(G T V H)$. A síntese que apresentaremos de ambas baseia-se na explanação feita por Ramos (2011, p. 42 a 45) a respeito. 
Raskin propõe na Teoria dos Scripts que os usuários de uma língua têm uma competência humorística (grifo no original) - conceito que ele fundamenta na competência linguística de Chomsky - que permitiria que a percepção de um modo de comunicação non-bona-fide (não confiável), se sobrepusesse ao bona-fide (confiável) no processamento textual, ou seja, "o texto começa a ser percebido de uma maneira e termina de outra, diferente da inicial" (RAMOS, op. cit, p. 43). No caso de uma piada tomada como exemplo prototípico -, para ser entendida como tal, 1) seu texto precisa ser compatível, total ou parcialmente, com dois scripts diferentes; 2) os dois scripts com os quais o texto é compatível precisam ser opostos. Um gatilho (tradução do termo inglês trigger usado por Raskin) localizado em um determinado trecho-chave (punch-line) opera a mudança de script que leva a uma ambiguidade ou contradição. Nas palavras de Ramos:

A piada tem, então, uma sequência própria, que passa pelas seguintes etapas, segundo resume Raskin:

1. troca do modo de comunicação bona-fide para o non-bona-fide;

2. o texto possui uma intenção de ser piada;

3. há dois scripts compatíveis com o texto;

4. ocorre uma relação de oposição entre os dois scripts;

5. um gatilho, óbvio ou implícito, evidencia a oposição de scripts. (idem)

$\mathrm{Na}$ reformulação da Teoria dos Scripts para a GTVH, Raskin e Attardo incorporam elementos de outras áreas teóricas da Linguística e o entendimento de uma piada passou a envolver então seis conhecimentos: (i) linguagem, (ii) estratégia narrativa, (iii) situação, (iv) oposição de scripts, (v) mecanismo lógico, (vi) alvo. Em que pese as críticas, as duas propostas se converteram, segundo Ruiz Gurillo (2012, p. 26), na mais influente teoria linguística sobre humor das últimas duas décadas. As principais críticas citadas por Ramos (2011) e por Ruiz Gurillo (2012) são: o fato de o modelo ter sido pensado sobre textos prototípicos e ser de difícil aplicabilidade em textos mais longos, a dificuldade de sistematizar o mecanismo lógico e a supervalorização de um dos aspectos cognitivos, o do humor, em detrimento de outros.

Ruiz Gurillo (2012, p. 17) diz ainda que no campo da Linguística Cognitiva, de onde partiram as críticas mais duras à TGVH, T. Veale, K. Freyaerts e G. Brône desenvolveram o conceito de espaço mental para explicar o humor. A autora menciona ainda a Teoria da Relevância entre as atuais correntes que estudam o funcionamento da expressão humorística. A própria autora desenvolveu uma proposta em que explica o humor como transgressão de princípios pragmáticos especialmente o da informatividade e 
da quantidade. Sua proposta leva em conta também aspectos relacionados ao contexto situacional como grau de familiaridade entre os interlocutores, traços socioculturais, idade, gênero etc. Na obra que vimos citando, ela apresenta os resultados de aplicar sua propostas a outros gêneros, que não a piada, que têm o humor como característica constitutiva, tais como monólogos em apresentações de stand up, sketchs de programas humorísticos televisivos, bem como a outros em que aparece de forma episódica, mas não constitutiva, como a conversação espontânea.

Retomando o quanto exposto, vemos que sob diferentes denominações, tais como "justaposição de sentidos divergentes" na abordagem freudiana, "transposição" e interferência de séries" para Bergson, "oposição de scripts" para Raskin e Attardo, a incongruência está na base de várias das visões aqui sintetizadas.

Reconhecendo a contribuição dos inúmeros estudos já realizados a respeito do humor, mas ao mesmo tempo identificando a lacuna de um quadro com categorias mais operatórias, Charaudeau propõe ver o humor como uma noção genérica, que pode ser objeto de diferentes caracterizações. Partindo de parâmetros originários da Análise do Discurso ele elabora uma série de categorias que permitem descrever e caracterizar o os atos humorísticos de um ponto de vista enunciativo e discursivo.

\section{A proposta de Charaudeau}

\subsection{O humor como uma noção genérica}

Para Charaudeau (2006), entender o humor como uma noção genérica significa comprendê-lo como uma estratégia discursiva que consiste em:

- confrontar a linguagem, livrar-se de suas imposições, sejam elas regras linguísticas (morfologia e sintaxe) ou normas de uso (como convenções sociais), como nos procedimentos que originam os jogos de palavra ou de pensamento;

- construir uma visão desencaixada, transformada, metamorfoseada de um mundo que se impõe a todos que vivem em sociedade;

- solicitar a um certo interlocutor (indivíduo ou auditório) que compartilhe desse jogo sobre a linguagem e o mundo, que entre em uma certa conivência de jogar junto, mas um jogar que leva o indivíduo a tornar-se outro, no próprio instante do ato humorístico, o que permite dizer que o ato humorístico não é jamais gratuito. Em sua totalidade, o humor corresponde sempre a uma visão lúdica, mas a ela podem ser acrescentadas outras visões mais críticas, ou até agressivas, que levam o sujeito humorista e seu interlocutor a estabelecerem um compromisso 
bem mais profundo. De qualquer forma, trata-se sempre de uma liberdade compartilhada, pelo fato de que o ato humorístico se volta, ora sobre o mundo, no desejo de questioná-lo, ora sobre o outro, no desejo de torná-lo cúmplice ${ }^{21}$.

\subsection{Uma relação triádica}

Charaudeau (2006) adverte que os atos humorísticos não constituem a totalidade da situação de comunicação, são atos de discurso que se inscrevem em situações que implicam diferentes contratos ${ }^{22}$, tais como publicitário, midiático, conversacional etc. São uma certa maneira de dizer no interior dessas diferentes situações, um ato de enunciação que consiste em uma estratégia para tornar seu interlocutor um cúmplice. Em alusão às duas dimensões que envolvem todo ato de linguagem, acrescenta que o ato humorístico é o resultado de um jogo que se estabelece entre os parceiros de uma situação de comunicação (instância situacional, espaço externo em que atuam os seres psicossociais) e os protagonistas da situação de enunciação (instância discursiva, espaço interno em que participam seres de fala).

Na proposta de Charaudeau, para estudar um ato humorístico, é preciso descrever (i) seu dispositivo comunicacional e enunciativo; (ii) sua temática; (iii) os procedimentos linguageiros postos em funcionamento; (iv) os possíveis efeitos que pode produzir.

Sobre o primeiro ponto, o autor vê o dispositivo comunicacional e enunciativo do ato humorístico como uma relação triádica na qual entram em cena três protagonistas: o locutor, o destinatário e o alvo.

\footnotetext{
${ }^{21}$ Tradução nossa dos originais em francês:

- "s'affronter au langage, se libérer de ses contraintes, qu'il s' agisse des règles linguistiques (morphologie et syntaxe) ou des normes d'usage (emplois réglés par des conventions sociales en situation), ce qui donne lieu à des jeux de mots ou de pensée";

- "construire une vision décalée, transformée, métamorphosée d'un monde qui s'impose toujours à l'être vivant en société";

- " demander à un certain interlocuteur (individu ou auditoire) de partager ce jeu sur le langage et le monde, d'entrer dans cette connivence de "jouer ensemble", mais un jouer qui engage l'individu à devenir autre, l'instant de l'acte humoristique, ce qui permet de dire que l'acte humoristique n'est jamais gratuit. Au total, l'humour correspond toujours à une visée ludique, mais à celle-ci peuvent s'adjoindre d'autres visées plus critique, voire agressive, qui engage le sujet humoriste et son interlocuteur à partager un engagement bien plus profond. En tout cas, il s'agit toujours d'un partage de liberté, du fait que l'acte humoristique est tourné, à la fois, vers le monde, dans le désir de le mettre en cause, et vers l'autre, dans le désir de le rendre complice

${ }^{22}$ Para Charaudeau o contrato de comunicação é o conjunto das condições nas quais se realiza qualquer ato de comunicação. É o que permite aos parceiros de uma troca linguageira reconhecerem um ao outro com os traços identitários que os definem como sujeitos desse ato, reconhecerem seu objetivo, o objeto temático e as circunstâncias em que ele se dá (CHARAUDEAU e MAINGUENEAU, 2004, p. 132).
} 
O locutor é o sujeito que, numa determinada situação de comunicação, produzirá o ato humorístico. Com relação a essa instância, o autor aponta que dois fatores são importantes: a legitimidade para fazê-lo e a forma de enunciação. No primeiro caso, muitas vezes a legitimação vem do próprio lugar que esse sujeito ocupa na situação de comunicação:

nas caricaturas, o desenhista é por definição um humorista; nos anúncios publicitários, para seduzir o consumidor o publicitário está autorizado a utilizar jogos de linguagem; nas crônicas jornalísticas de humor o cronista comenta a atualidade pincelando seu texto com traços humorísticos. Nos outros casos, em particular aqueles da conversação espontânea, o locutor deve ter meios de justificar sua enunciação humorística porque há o risco de ser mal interpretado por seu interlocutor. ${ }^{23}$

No que se refere à forma de enunciação, o locutor pode trazer para a cena personagens-enunciadores, como no caso de contar uma piada, ou uma história engraçada. Em alguns casos, é na identidade ou nos papéis sociais desses personagens que repousa o sucesso do humor. É o caso, por exemplo, da tira de autoria de Caloi, publicada no Clarín em 29/06/2002, durante a Copa daquele ano, e que reproduzimos na figura 2. Seu tema é o episódio da eliminação do Japão, um dos anfitriões, pela Turquia durante as oitavas de final.

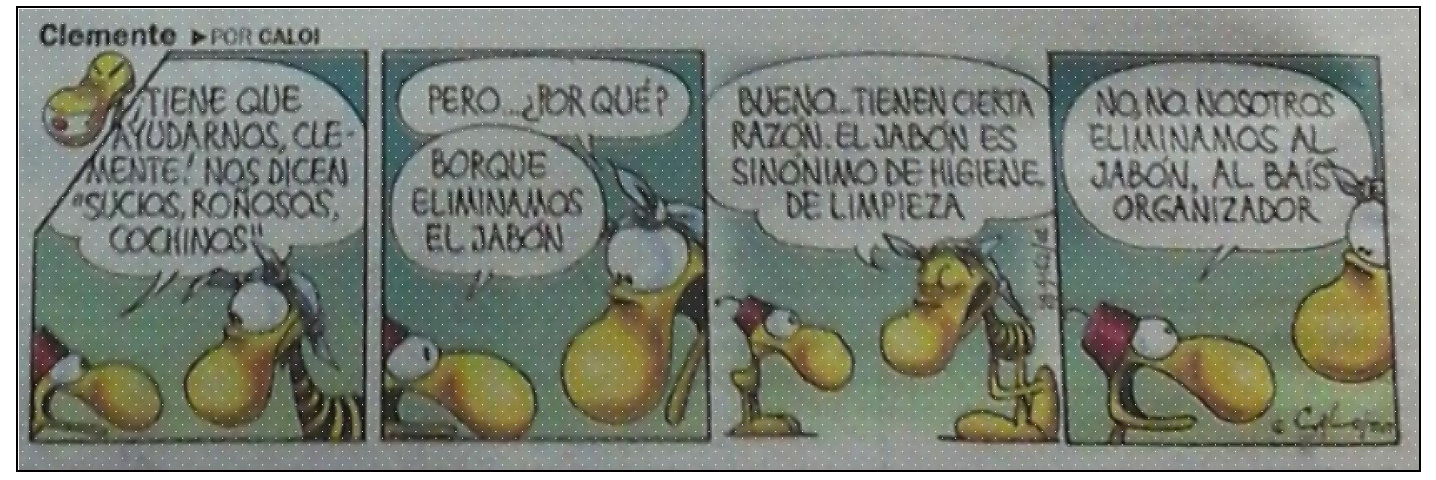

Figura 2 - Clemente - Jabón - Fonte: Clarín - 29/06/2002

Nesta tira, o humor reside na exploração de um estereótipo, o sotaque dos turcos ao falar espanhol. Para imitar esse sotaque, na fala de um dos locutores-personagem o autor substitui a letra $p$ pela $b$, o que provocará um jogo entre os sentidos das palavras

\footnotetext{
${ }^{23}$ Tradução nossa do original em francês: "dans les caricatures, le dessinateur est par définition un humoriste; dans les annonces publicitaires, le publicitaire s'autorise, pour séduire le consommateur, à jouer avec le langage ; dans les chroniques journalistiques d'humeur, le chroniqueur commente l'actualité en émaillant son texte de traits humoristiques. Dans d'autres cas, particulièrement ceux de la conversation spontanée, le locuteur doit se donner les moyens de justifier son énonciation humoristique car il risque d'être mal considéré par son interlocuteur."
} 
jabón e Japón na interação entre os locutores-personagem no universo ficcional da tira. A confusão só será elucidada ao final, provocando o desfecho cômico e revelando que a conversa era sobre a eliminação do Japão e não do sabão.

Quanto ao destinatário no ato de linguagem humorístico, ele pode ocupar um lugar de cúmplice ou de vítima. No primeiro caso - cúmplice - o locutor busca sua conivência, convidando-o a compartilhar não só da visão deslocada do mundo proposta pelo enunciador como também do juízo de valor deste último sobre o alvo. Nesse sentido, o destinatário se converte em uma espécie de testemunha do ato humorístico. Quando o destinatário é a vítima, converte-se também em alvo do ato de humor. Nesses casos, entre as reações possíveis estão aceitar rir de si mesmo, fazer ouvidos de mercador ou replicar da mesma forma

O alvo é o objeto sobre o qual, ou a propósito do qual, o ato humorístico é exercido. Tanto pode ser uma pessoa, com natureza individual ou coletiva, em uma posição de terceiro na cena humorística, como também uma ideia, uma opinião, um fato social ou um acidente da natureza, por exemplo. Conforme o autor, "é por intermédio do alvo que o ato humorístico questiona a visão normatizada do mundo procedendo aos desdobramentos, disjunções, discordâncias e dissociações com relação à ordem das coisas" $^{24}$ (CHARAUDEAU, 2006).

A respeito da temática, Charaudeau chama a atenção sobre o grau de aceitabilidade social e cultural de determinados temas. Nesse aspecto entram as questões que podem ser tabu ou não em determinadas sociedades: a vida, a morte, a saúde, crenças religiosas $^{25}$, idade etc. $\mathrm{O}$ humor será julgado legítimo ou ilegítimo segundo a natureza desses domínios temáticos para uma determinada sociedade ou comunidade.

\footnotetext{
${ }^{24}$ Nossa tradução do francês: “C'est par l'intermédiaire de la cible que l'acte humoristique met en cause des visions normées du monde en procédant à des dédoublements, des disjonctions, des discordances, des dissociations dans l'ordre des choses".

${ }^{25}$ Esse aspecto adquiriu especial relevância nos dias atuais, não só pela questão da ideologia do politicamente correto, como também pela forma como grupos extremistas têm reagido à sátira de elementos religiosos em charges e cartuns. A esse respeito, recordamos que em 07 de janeiro de 2015, a redação do jornal Charlie Hebdo, um semanário francês de humor caracterizado pela irreverência e iconoclastia levadas às últimas consequências, foi invadida por homens armados que assassinaram doze pessoas. A razão seriam as charges frequentemente publicadas pelo jornal, consideradas ofensivas aos muçulmanos.
} 


\subsection{Os procedimentos linguageiros para o humor e seus possíveis efeitos}

É precisamente sobre esses dois aspectos - os procedimentos e seus efeitos possíveis - que a proposta de Charaudeau elenca categorias. O autor reconhece que a categorização é objeto de muita controvérsia no campo da análise de textos e de tipos de discurso. Seu ponto de vista é que a força das ciências humanas e sociais está justamente em definir categorias que permitem proceder às análises e de avaliar os resultados seguindo princípios coerentes. Mas, ao mesmo tempo, é preciso não se deixar aprisionar por categorias porque elas são, por definição, redutoras. Assim, seu objetivo foi estabelecer categorias operatórias e não essencializantes. Nesse sentido, buscou em sua definição aquelas que permitissem analisar os atos humorísticos caso a caso e entendendo que às vezes será a combinação delas que possibilitará a interpretação de um ato de humor e de suas particularidades.

Passando à apresentação de sua classificação, Charaudeau divide os procedimentos linguageiros em dois grupos: os linguísticos e os discursivos.

Os procedimentos linguísticos decorrem do mecanismo léxico-sintático-semântico e dizem respeito aos signos, à sua forma e seu sentido, bem como à relação formasentido. O autor cita a homonímia e a polissemia, como procedimentos linguísticos que permitiriam passar de uma isotopia ${ }^{26}$ a outra, e palíndromos, trocadilhos e palavras-valise como exemplos resultantes desses procedimentos. Charaudeau não faz uma descrição exaustiva desses procedimentos, apenas acrescenta que eles não têm valor humorístico em si, podendo inclusive ser usados em gêneros sérios, como a poesia.

Em nosso ponto de vista, a proposta de Charaudeau revela-se especialmente produtiva na classificação que o autor faz dos procedimentos discursivos, aqueles que dependem mais diretamente dos mecanismos de enunciação, das posições dos sujeitos participantes (locutor e destinatário), do contexto e do valor social do domínio temático em que se dá o ato humorístico.

\footnotetext{
${ }^{26}$ Segundo Charaudeau e Maingueneau (2008), "isotopia designa globalmente os procedimentos que concorrem para a coerência de uma sequência discursiva ou de uma mensagem. Fundada na redundância de um mesmo traço no desenvolvimento dos enunciados, tal coerência diz respeito principalmente à organização semântica do discurso".
} 


\subsubsection{Os procedimentos discursivos}

Ao discutir os procedimentos discursivos, Charaudeau distingue os enunciativos dos lógico-semânticos. Nesses últimos, o humor resulta de operações com o próprio valor semântico das palavras no interior do enunciado e jogam com a dissociação de isotopias. Por exemplo, nesta frase comparativa de domínio popular "era um rapaz tão burro, tão burro, mas tão burro que fez exame de sangue e reprovou", temos um procedimento humorístico do tipo lógico-semântico pois se joga-se com a polissemia da palavra exame colocando duas isotopias em relação: aferição de conhecimentos e procedimento de saúde.

Quanto aos procedimentos enunciativos, eles implicam em um jogo entre o que é dito (o explícito) e o que se quer dizer (o implícito). Charaudeau os subdivide em jogo enunciativo irônico, sarcástico e paródico.

\subsubsection{O jogo enunciativo irônico}

A ironia talvez se trate de um dos conceitos mais estudados e sobre o qual existem mais possibilidades de interpretação. Para Charaudeau, o jogo enunciativo irônico consiste em colocar o destinatário em uma posição em que ele deve calcular a relação entre o que é dito explicitamente a intenção oculta que esse explícito recobre. O autor aponta três características para essa categoria: (i) a ironia é um ato de enunciação que produz uma dissociação entre o que é dito e o que é pensado; (ii) que faz coexistir essa dissociação - o que distingue a ironia da mentira, por exemplo. E, ademais, (iii) o que é dito se apresenta sempre como uma apreciação positiva mascarando o que é pensado, sempre negativo.

\subsubsection{O jogo enunciativo sarcástico}

Embora guarde semelhanças com a ironia, no sarcasmo a relação entre o dito e o pensado não é a mesma. O que é dito no sarcasmo, segundo Charaudeau, é sempre negativo e ocorre uma hiperbolização desses aspectos, com um grau de agressividade, inclusive. O sarcasmo, segundo o autor, rompe com as regras do convívio em sociedade. Pelo sarcasmo se diz o que não deve ser dito, colocando o interlocutor em situação 
desconfortável. Nessa categoria Charaudeau abriga também a zombaria e a sátira, salientando que nesses casos entra em cena também o grotesco.

\subsubsection{O jogo enunciativo paródico}

Charaudeau compara a paródia à citação, sinalizando que se trata de uma citação peculiar. Segundo ele, parodiar é escrever - ou falar - um texto já existente, alterando alguns elementos de sorte que esse novo texto não possa ser confundido com o texto de referência, ou seja, apresentar esse texto como uma imitação do original e não como tal. A paródia faz coexistir os dois textos que se alimentam reciprocamente. Nesse caso está previsto um interlocutor que possa reconhecer o texto de origem e extrair, com isso, os implícitos do discurso. Para exemplificar, cita os programas televisivos ou radiofônicos com características de noticiários nos quais humoristas imitam personalidades do mundo político ou artístico. O efeito de humor advém da coexistência de um original e de sua imitação reconstruída.

\subsubsection{Os procedimentos lógico-semânticos}

Como já afirmado, o humor pelos procedimentos lógico-semânticos consiste em um jogo com a polissemia das palavras para construir dois ou mais níveis de leitura ao longo da construção frástica (isotopia) em torno de palavras que podem ter dois ou mais sentidos. O autor distingue três tipos de procedimentos lógicos semânticos, segundo a relação que se estabelece entre esses universos colocados em relação.

\subsubsection{A incoerência louca}

Nesses casos estabelece-se uma relação entre universos que nada têm a ver uns com os outros, os quais se unem por meio de uma narração em que a relação de causalidade não é, em princípio, visível e que transgride a lógica humana, aproximandose das histórias de loucos. Não está presente na incoerência louca juízos de valor como na ironia ou no sarcasmo porque não há laços lógicos entre os eventos. 


\subsubsection{A incoerência insólita}

Embora a ligação entre os dois universos postos em relação nesses casos não seja natural, ela se torna perceptível pela narrativa ou pela situação em que se encontram. Há uma espécie de transferência de sentido entre esses universos e, diferentemente do caso anterior, é possível explicar essa transferência pela polissemia de algum termo, um detalhe dentro da narrativa etc. Nas palavras do autor:

A diferença entre a incoerência louca e a insólita é, algumas vezes, difícil de estabelecer. Com efeito, a diferença reside na existência ou não de um elo entre os dois universos de significado (ou isotopias) postos em relação. Esse elo é obtido por inferência, e a questão que se coloca é saber se a inferência é evidente ou não. Se a relação semântica aparece facilmente (é verdade que facilmente é um critério difícil de mensurar), estamos diante de uma incoerência insólita; caso contrário, de uma incoerência louca ${ }^{27}$.

Como exemplo para essa diferenciação, Charaudeau cita uma frase da coluna Bisturí de 21 de fevereiro de 2002 assinada pela jornalista Maruja Torres publicada no jornal espanhol El país no qual a autora afirma que seu sonho atual consistia em "que la práctica de lobotomías sea admitida por la sanidad pública y que me la apliquen masiva e inmediatamente. Porque sólo mediante lobotomía previa voy a poder enfrentarme a diario con la información ${ }^{28 \%}$. A priori, não há nenhuma relação entre notícias, lobotomia e sistema público de saúde, mas podemos estabelecer um nexo entre elas para chegar à conclusão de que as notícias estão tão ruins que para suportá-las é preciso ter a capacidade intelectual reduzida por uma lobotomia, financiada pelo sistema público, porque se trata de uma cirurgia de grande porte. Nesse caso, trata-se de uma incoerência insólita. Já para ilustrar um caso de uso do procedimento da incoerência louca, Charaudeau cita o exemplo de um cronista francês que em resposta a um leitor disse que mesmo que ele, cronista, serrasse a coluna de um monumento em Paris com um talher ou comesse todas as ostras do mundo correndo nu por uma avenida dessa cidade determinado evento não aconteceria. Como vemos, nesse caso não é possível estabelecer

\footnotetext{
${ }^{27}$ Nossa tradução para La différence entre incohérence loufoque et incohérence insolite est parfois difficile à établir. En fait, la différence réside dans l'existence ou non d'un lien entre les deux univers de sens (ou isotopies) mis en relation. Ce lien, on l'obtient par inférence, et toute la question est de savoir si l'inférence est elle-même évidente ou non. Si le lien sémantique apparaît facilement (il est vrai que facilement est un critère difficile à mesurer), on a affaire à une incohérence insolite ; dans le cas contraire, à une incohérence loufoque.

${ }^{28}$ Disponível em http://web2.edicioneselpais.net/diario/2002/02/21/ultima/1014246002 850215.html
} 
relação entre os diferentes elementos tomados pelo cronista para expressar, de forma bem humorada, que era impossível o evento acontecer.

\subsubsection{A incoerência paradoxal}

Nesses casos estabelece-se uma relação de contradição entre duas lógicas da mesma isotopia. Trata-se de um fato do discurso que vai contra a lógica, não exatamente a lógica universal, e sim aquela garantida pelas normas sociais. Seu resultado é uma contradição inaceitável. Diferentemente das duas anteriores, a incoerência paradoxal, para Charaudeau, permite discutir, raciocinar sobre o paradoxo e, eventualmente, refletir sobre o que está sendo questionado. Em comparação ainda com as outras, na incoerência louca temos uma falta de sentido (hors-sens), na insólita um trans-sentido (trans-sens), na paradoxal temos um contrassenso (contre-sens) "avaliado, não mais sobre o encontro entre eixos paradigmáticos diferentes, mas sobre a lógica argumentativa que se desenvolve no eixo sintagmático ${ }^{29}$, . O exemplo citado pelo autor é uma anedota na qual se conta que um louco, ao descobrir que estava entre os muros no hospício, escala um deles para espiar o que há do outro lado e indaga a uma das pessoas que vê passar: "Me diga, companheiro, vocês são muitos aí desse lado $?^{30}$, história que nos leva a questionar quem está dentro e quem está fora do quê.

\subsubsection{Os efeitos possíveis}

O efeito possível de um ato humorístico, conforme Charaudeau, resulta do tipo de questionamento do mundo e do contrato de conivência que o humorista propõe ao destinatário, que exige que ele - destinatário - se posicione a respeito. $\mathrm{O}$ autor identifica quatro diferentes tipos de conivência para os possíveis efeitos de um ato de humor: a lúdica, a crítica, a cínica e a de derrisão, as quais, esclarece, se distinguem, mas também podem se sobrepor.

$\mathrm{O}$ autor alerta que esse ponto embute a problemática que consiste em supor que se lida com as intenções dos sujeitos que participam de um ato de comunicação. A esse respeito, recorda que ao analista cabe construir interpretações com o que tem à disposição

\footnotetext{
${ }^{29}$ Nossa tradução para o original em francês: “qui se juge, non plus sur la rencontre entre des axes paradigmatiques différents, mais sur la logique argumentativo qui se développe sur l'axe sintagmatique" ${ }^{30}$ Nossa tradução para "Dites-moi, mon brave, vous êtes nombreux là-dedans ?"
} 
e que não se trata de estabelecer intenções - pretendidas e alcançadas - ou correspondências entre elas.

\subsubsection{A conivência lúdica}

A conivência lúdica consiste em um alegrar-se pelo ato em si, em uma fusão emocional entre o autor e o destinatário, livre de qualquer espírito crítico. Trata-se de partilhar uma outra maneira de ver as estranhezas do mundo, sem preocupação com um engajamento moral. $\mathrm{O}$ autor adverte, no entanto, que pode haver subjacente no ato de humor que um questionamento sobre normas sociais.

\subsubsection{A conivência crítica}

A conivência crítica supõe polêmica, há uma contra-argumentação implícita. Pelo ato de humor se propõe ao destinatário que compartilhe de uma opinião sobre algo ou alguém, o que supõe às vezes a denúncia de falsos valores ou o questionamento de uma ordem estável. Charaudeau esclarece que esse tipo de conivência é pouco encontrada em atos de humor presentes em gêneros publicitários, por outro lado, é abundante nas charges e nas caricaturas.

\subsubsection{A conivência cínica}

A conivência cínica tem um efeito destruidor. Aqui, o objetivo é compartilhar a dessacralização de valores que a norma social considera positivos e universais, que podem dizer respeito ao homem, à vida, à morte. O sujeito humorista se coloca em uma posição de poder em que ataca a tudo e a todos. É o tipo de conivência que se identifica em piadas sexistas, racistas.

\subsubsection{A conivência de derrisão}

Na conivência de derrisão o objetivo é desqualificar o alvo, rebaixando-o, isto é, fazendo-o descer do pedestal sobre o qual ele acredita que se encontra. Tem em comum com a conivência crítica a desqualificação sobre uma pessoa ou uma ideia, porém diferentemente dela, não envolve nenhum desenvolvimento argumentativo a respeito. A 
derrisão desqualifica brutalmente, sem apelar, sem defesa possível. Ao contrário, a crítica supõe uma justificativa.

Antes de explicitar como aplicaremos a proposta de Charaudeau em nossa pesquisa, é necessário explicitar sobre a relação entre humor e tiras cômicas.

\section{Humor e tiras cômicas}

Em nosso trabalho, assumimos as tiras cômicas como um gênero discursivo que tem no humor um de seus aspectos constitutivos. É possível, inclusive, assemelhá-las às piadas. É justamente o que aponta Ramos (2011), quem, em trabalho comparativo sobre os dois gêneros, identifica que ambos utilizam estratégias textuais de construção de sentido semelhantes possuindo muitas características comuns, mas também algumas diferenças. Entre as semelhanças, destacamos (RAMOS, 2011, p. 207-208) serem textos narrativos tendencialmente curtos; terem vinculação ao campo do humor; operarem com "duas leituras, uma séria e outra não séria ou jocosa" como uma estratégia própria do princípio da incongruência de levar o leitor para um caminho de sentido e depois surpreendê-lo, quebrando sua expectativa de leitura, o final inesperado

- tendência ao uso de diálogos no processo de construção e condução do texto;

- tendência a ter o humor focalizado em atitudes (verbais ou gestuais) centradas nos personagens;

- presença de personagens fixos e não fixos na narrativa; os fixos exigem conhecimento compartilhado dos parceiros da interação, tanto para a produção do texto como para sua compreensão (e também do efeito de humor);

- tendência a apresentar atitudes e personagens estereotipados, de modo a facilitar a compreensão das características situacionais e de composição do personagem para o leitor ;

Quanto às diferenças, o autor destaca três pontos: os diferentes recursos envolvidos na expressividade de cada um dos gêneros, a questão da autoria e o uso da imagem. No que se refere ao segundo ponto, o autor aponta que as piadas orais são normalmente de autoria anônima, característica que às vezes muda nas piadas escritas, especialmente em casos de coletâneas assinadas por humoristas. Já nas tiras cômicas, a "tendência é a presença do autor real (ou não-ficcional). O nome dele é apresentado ao leitor no canto superior direito da tira, na capa das coletâneas ou na indicação da autoria dos blogs" (p. 208). Ramos aponta que eventualmente uma tira pode aparecer sem o nome 
do autor, embora reforce que seja algo raro. O fato de o autor estar identificado, ou sua presença "interfere ou pode interferir na maneira como o leitor toma contato com o texto, determinado autor pode criar uma determinada expectativa, não percebida em outro" (idem).

Como enfocamos as tiras cômicas circunscrevendo-nos à sua publicação em jornais diários, a autoria é uma dimensão importante. Especialmente se pensamos que no público-leitor que lê determinada publicação assiduamente não só as expectativas são importantes, como também os conhecimentos partilhados que decorrem de acompanhar ou não um autor, conhecer seu estilo e as características dos personagens que cria e que enunciam no espaço ficcional.

\section{Nosso posicionamento}

Visto que nosso objetivo não é verificar a funcionalidade ou a aplicabilidade de um modelo que explique o funcionamento do humor, mas, sim, analisar as tiras cômicas explorando sua dimensão discursiva - onde se dá a relação entre língua e contexto sóciohistórico -, vemos a proposta de Charaudeau (2006) como adequada aos nossos propósitos e ao mesmo tempo compatível com a ideia de cenografia de Maingueneau (2001, 2010), pois ambos os autores trabalham com princípios oriundos da Análise do Discurso francófona e da Pragmática. Além disso, como pudemos comprovar em outros trabalhos que também se valeram dessas categorias ${ }^{31}$ e nos exemplos proporcionados por Charaudeau (2006), sua proposta permite contemplar também os aspectos não verbais de nosso objeto de estudo.

Assim, a partir do que expusemos, neste trabalho a dimensão do humor nas tiras cômicas foi examinada conforme proposto por Charaudeau (2006), ou seja, como um ato humorístico que envolve um dispositivo comunicacional e enunciativo, temas, procedimentos linguageiros e possíveis efeitos tal como apresentadas e resenhadas neste capítulo. Quanto ao primeiro ponto, destacamos que fizemos uma pequena adaptação na nomenclatura utilizada pelo autor francês para referir-se aos participantes desse dispositivo comunicacional. Chamamos "o sujeito que numa determinada situação de comunicação produzirá o ato humorístico" como emissor, reservando o termo locutor

\footnotetext{
${ }^{31}$ No Brasil, localizamos que a pesquisadora Sandra Falcão da Silva (mestrado na PUC-SP e doutorado na USP) realizou pesquisas em que aplicou a proposta de Charaudeau em suas análises. Silva trabalhou no mestrado com ironias nas crônicas de Diego Mainardi, e no doutorado com charges da imprensa francesa (dessin du presse).
} 
para o seu correlato como um dos parceiros na situação de enunciação. Quando se trata da interação dentro do universo ficcional das tiras, usamos locutor-personagem ou locutornarrador, segundo o caso. Identificamos como enunciador as vozes que manifestam pontos de vista no plano ficcional das tiras. 


\section{CAPÍTULO 3 - Futebol e identidades nacionais na Argentina e no Brasil}

\section{Introdução}

Brasil, Argentina e futebol. No senso comum essa associação é quase imediata e decorre de sentidos construídos discursivamente - entendendo discurso de forma ampla compreendendo não só o verbal - em ambos os países em torno desse esporte. Vários estudos no campo da História e das Ciências Sociais têm mostrado o papel que o futebol desempenhou nas narrativas de construção identitária de ambos os países e a esse aspecto vamos dedicar as linhas que seguem.

Começaremos situando o conceito de identidade, em seguida circunscreveremos a questão ao que nos concerne e abordaremos em breves linhas o percurso descrito pelo futebol, desde sua criação como esporte na Inglaterra, até sua popularização no Brasil e da Argentina. Por fim, discorreremos sobre o papel que eventos esportivos como a Copa do Mundo de futebol desempenham nas narrativas identitárias nacionais.

\section{Aproximação ao conceito de identidade}

Um dos primeiros aspectos com relação à noção de identidade é que ela se constitui por mecanismos de diferenciação e igualdade. Conforme Ciampa (1997, p. 63), para nos identificarmos vamos sucessivamente nos igualando aos membros dos vários grupos sociais de que fazemos parte e também nos diferenciando deles: brasileiro, igual a outros brasileiros, mas paulista, não carioca; professor, igual a outros professores, mas professor universitário e não de ensino fundamental etc. $\mathrm{O}$ autor faz inclusive uma comparação desse processo com o nosso nome, enquanto o primeiro nos dá nossa individualidade, o sobrenome nos iguala aos membros de nossa família (idem).

Nessa mesma direção aponta Woodward ([1997] 2014, p.9) quem destaca que a identidade é relacional e marcada pela diferença. Para existir, uma identidade depende de algo externo a ela, a saber, outra identidade, que é diferente dessa primeira, mas que, no entanto, fornece as condições para que ela exista.

Se ficarmos somente com esse primeiro aspecto, tenderemos a pensar que a identidade é algo dado, que trazemos pronto. Efetivamente durante algum tempo entendeu-se a identidade na perspectiva essencialista, nossa origem - seja em termos de nacionalidade ou familiar, por exemplo - nos faria herdeiros de um conjunto de 
características homogêneas comuns a todos com aquela mesma origem. Embora no âmbito especializado essa seja uma perspectiva superada, no senso comum é uma ideia bastante arraigada: se nasceu no Brasil, sabe sambar; se é argentino, gosta de carne e de tango etc.

Um segundo aspecto importante, portanto, a respeito do conceito é que atualmente, em oposição a uma concepção de identidade como algo unificado, integral, pré-existente, entende-se que a identidade não é una, resulta de processos, é algo construído e mutável.

Nesse processo a linguagem tem um papel fundamental. A esse respeito, Silva ([2000]2014, p. 76 e 77) recorda que identidade e diferença, além de serem interdependentes, são ambas "o resultado de atos de criação linguística". O autor enfatiza que afirmar isso "significa dizer que não são 'elementos da natureza', que não são coisas que estejam simplesmente aí, à espera de serem reveladas ou descobertas, respeitadas ou toleradas". Por conseguinte, a identidade e a diferença são ativamente produzidas no contexto de relações culturais e sociais, são criadas por meio de atos de linguagem. Ainda segundo o autor, "a definição da identidade brasileira, por exemplo, é o resultado da criação de variados e complexos atos linguísticos que a definem como sendo diferente de outras identidades nacionais".

Destacamos ainda, também conforme Silva (op. cit., p. 84), que os processos de construção identitária oscilam entre dois movimentos: por um lado aqueles que tendem a fixar e estabilizar a identidade e por outro, processos que tendem a subvertê-la e a desestabilizá-la. O autor assemelha esse processo ao que acontece com os mecanismos discursivos e linguísticos nos quais a produção da identidade se sustenta. Segundo ele, "tal como a linguagem, a tendência da identidade é para a fixação. Entretanto, tal como ocorre com a linguagem, a identidade está sempre escapando. A fixação é uma tendência e, ao mesmo tempo, uma impossibilidade" (p. 84).

Como sabemos, a língua é um dos elementos centrais nos processos de fixação e Silva também aborda esse aspecto. O autor (idem, p. 85) recorda que a história da construção dos Estados Nacionais é também a história da imposição de uma língua nacional única e, acrescentamos, de sua sistematização em instrumentos como gramáticas normativas e dicionários. Silva acrescenta que ademais de uma língua nacional também

é central a construção de símbolos nacionais: hinos, bandeiras, brasões. Entre esses símbolos, destacam-se os chamados 'mitos fundadores'. Fundamentalmente, um mito fundador remete a um momento crucial do passado em que algum gesto, algum acontecimento, em geral heroico, épico, monumental, em geral iniciado ou executado por alguma figura 'providencial', inaugurou as bases de uma suposta identidade nacional. 
Neste trabalho, nos interessa uma dimensão dos "mitos fundadores" que não está documentada em livros escolares, uma das vias pelas quais também se forja uma identidade nacional, mas sim em discursos não institucionalizados, mais exatamente aqueles que atrelam na Argentina e no Brasil as identidades nacionais ao futebol. Como destaca Alabarces (2006, p.148), quando se trata desses países, o peso do futebol nos processos de elaboração de uma identidade nacional é desmesurado,

no sólo por la manera como permea las sociabilidades cotidianas, sino por su importancia en la construcción de narrativas nacionales, de mitos de integración racial, de relatos de héroes que desbordan los campos de juego para transformarse en íconos de argentinidad o en un rei atleta do século.

Para apreender minimamente a gênese desse processo será necessário rever sinteticamente como o esporte chegou e se implantou nos diferentes países, aspecto ao qual nos dedicaremos no próximo item.

\section{O futebol na Argentina e no Brasil}

Como esporte, o futebol nasceu na Inglaterra, a meados do século XIX. Franco Júnior (2007, p. 23) cita que a uniformização das regras ocorreu em 1848 e põe como marco final para estabilização dos últimos ajustes o ano de 1912. Sobre sua origem, no entanto, conforme o mesmo autor (p.19), tudo são especulações. Há dados a respeito da prática de jogos com bola, ou um objeto similar a uma bola, e outras possíveis semelhanças ao futebol entre os meso-americanos, entre os anglo-normandos na época medieval, entre os romanos e vários outros povos. A esse respeito, Franco Júnior salienta que não é possível estabelecer uma linha de continuidade entre essas práticas e cada uma delas "respondia a condições culturais específicas, o que torna muito frágil vê-las como antepassadas do futebol" (p. 20), devendo ser considerados apenas jogos com bola e, como tais, manifestações antropológicas.

O mesmo autor sintetiza muito bem o processo de expansão do esporte para outros países e continentes. Segundo ele:

O futebol era às vezes transplantado por ingleses que trabalhavam ou estudavam no exterior, como ocorreu em diversas cidades belgas na década de 1860, suiças em 1860-80, Buenos Aires em fins dos anos 1860 ou começo dos 1870 (...). Outras vezes, pessoas que iam estudar 
na Inglaterra na volta introduziam aquela prática esportiva e social nos seus países, (...) como o paulista Charles Miller, descendente de escoceses pelo lado paterno e de ingleses pelo lado materno, que em 1894 trouxe duas bolas de futebol e um exemplar do livro de regras para o Brasil.

O pai de Miller viera para o Brasil para trabalhar na São Paulo Railway e mandara o filho para a Inglaterra para estudar. Embora seja esta a versão mais conhecida, é fato que há relatos de marinheiros ou outros funcionários de companhias inglesas jogando futebol no Brasil antes do desembarque de Miller em 1894 (WISNIK, 2008, p. 200). A via de disseminação do esporte no Brasil começa nos clubes das elites paulista e carioca que associaram à sua origem um "timbre aristocrático" (WISNIK, 2008, p. 201). Mas não tardaria a se repetir aqui o mesmo que acontecera na Inglaterra: as camadas médias e subalternas da sociedade também se organizaram e passaram a praticá-lo. Franco Júnior (2007, p. 65) assim comenta esse processo:

As fronteiras sociais do futebol começaram a ser transpostas desde cedo com a formação de times improvisados pelos setores populares, que passavam da curiosidade ao mimetismo. Sem equipamentos adequados e jogando com bolas desgastadas e mesmo improvisadas, em terrenos ainda não ocupados pelo processo de urbanização, o futebol dos grupos subalternos tornava-se um modo de representação da existência negada em outros campos sociais. E alastrava-se pelos subúrbios proletários.

Na Argentina, Frydenberg (2011, pp. 25 e 26) identifica três vias na chegada do futebol à cidade de Buenos Aires e seu posterior desenvolvimento. Uma primeira mítica, segundo a qual marinheiros ingleses teriam jogado no porto da cidade sendo observados pelos portenhos e a partir disso o esporte teria se disseminado. A segunda, identificada pelo autor como frustrada, diz respeito à primeira partida de futebol ocorrida no país e da qual há registros. Os jogadores pertenciam ao Buenos Aires Cricket Club e essa experiência deu origem ao Buenos Aires Football Club. Frydenberg destaca, no entanto, que a iniciativa que realmente inaugurou a tradição futebolística na cidade foi a das instituições educacionais da colônia inglesa.

A partir dessa chegada, a popularização do esporte segue caminhos e atribuições de sentido um pouco distintos em cada um dos países. No entanto, é preciso destacar que os ingleses, nesse momento, são parte dos mitos de origem em ambos os países, "como uma espécie de 'outro' primordial dos quais é necessário subtrair o saber para recriá-lo, mito que é revivido periodicamente nas competições internacionais" (GUEDES, 2006, p. $135)$. 
A mesma autora, a partir das reflexões desenvolvidas por Pablo Alabarces, aponta que no processo de diferenciação e de desenvolvimento dos chamados "estilos nacionais" de jogo na Argentina e no Brasil podem ser identificados dois eixos: frente aos ingleses (mito de nacionalidade) e frente às classes hegemônicas que haviam passado a praticá-lo em ambos os países (mito de origem social).

Ainda conforme Guedes (op. cit. p, 136) a popularização do futebol, ou seja, sua apropriação por estratos mais amplos da sociedade, se desenrola nas duas primeiras décadas do século XX em ambos os territórios, apesar de o esporte ter chegado bem antes à Argentina. Esse processo, também nos dois casos, antecede o surgimento de uma imprensa esportiva e a própria espetacularização do jogo. É importante sinalizar que em ambos os casos igualmente estavam em cena naquele então as tensões relacionadas à homogeneização dos territórios e suas populações em nação.

Até esse momento identificamos as similitudes, há, no entanto, um ponto de clivagem, e ele está nos elementos étnicos que são chamados a compor a história do futebol: "de um lado da fronteira, italianos, espanhóis e gaúchos, do outro, índios, negros e brancos" (GUEDES, 2006, p.140).

No caso argentino, à herança latina de italianos e espanhóis junta-se a essência gaucha, como apontou o antropólogo e sociólogo argentino Eduardo Archetti (1995). Esse autor em sua carreira acadêmica desenvolveu reflexões basilares sobre o futebol, que servem de fundamentação para vários dos especialistas que consultamos. Assim, notamos que tanto Guedes (2006) como Alabarces (2006) mencionam que em seus estudos Archetti vê o fútbol criollo ou la nuestra como resultado de um conjunto de transformações do modelo do gaucho fecundado pelas qualidades físicas e morais dos europeus de origem latina que chegaram como imigrantes à Argentina. Esse processo é comparado à fecundação das éguas criollas pelos garanhões puro-sangue. "Híbridos os cavalos, híbridos os homens. Espaços para jogos de futebol (correspondentes aos campos de pelada ou várzea brasileiros) são chamados de potreros, recuperando a cada momento a herança gaucha" (GUEDES, 2006, p. 140). Sintetizamos com o próprio Archetti (2008) essa ideia:

Las nociones de una identidad argentina no son necesariamente cerradas, ellas pueden conceptualizarse en contraposición con otras identidades (reconocidas o no por los nativos mismos). Las ideas e imágenes de lo "nacional" son, a menudo, un espejo en el que la mirada de los otros es casi tan importante como la mirada de los nativos mismos. Pienso que el fútbol en la Argentina es una arena privilegiada 
para el análisis de la formación de la identidad nacional y la construcción de masculinidades (Archetti, 1994 ${ }^{32}$ ). A comienzos de este siglo el fútbol fue visto como un deporte de origen británico que se hacía nacional -e interno- en un momento en el que se desarrollaban las redes globales de intercambios y de competencias deportivas. El fútbol permitió a los hombres argentinos competir y hacerse visibles en un mundo cada vez más internacional (juegos olímpicos, torneos sudamericanos, giras europeas de equipos desde 1925, y -desde 1930la Copa del Mundo Jules Rimet).

Já no lado brasileiro, o construto se alimenta em parte do mito das três raças, com ênfase na presença do negro. Esse elemento será um sinal diacrítico segundo Guedes (idem), uma diferença essencial representada pela "incorporação símbólica do negro como responsável pela forma 'espontânea' de usar o corpo em 'dribles, malandragem, jogo de cintura' sem qualquer esforço de aprendizagem”.

No âmbito teórico, a obra clássica de Gilberto Freyre, Casa Grande e Senzala, publicada pela primeira vez em 1933, marca uma virada no entendimento do papel da mestiçagem na construção do país, que passa a ser vista como um valor positivo e força maior da população brasileira. Helal (2014, p. 9) destaca ainda que o próprio Freyre publicou em 1938, em sua coluna no Diário de Pernambuco, o artigo "Foot-ball mulato" no qual elogia a mestiçagem racial e afirma que ela funda um estilo de jogo que seria típico do Brasil - "uma dança dionisíaca" -, posteriormente denominado futebol arte. Não pensemos, no entanto, que essa assimilação do negro ao futebol se deu de forma natural e pacífica. Como já mencionamos com base em Wisnik, o início do futebol no Brasil foi extremamente elitista e branco. E, em mais uma amostra da falsa "democracia racial" que vivemos no Brasil, a história do processo de participação de negros no esporte está recheada de episódios de racismo explícito por parte de clubes e inclusive de governantes. Episódios que lamentavelmente continuam a se repetir nos estádios nacionais e internacionais.

Outro elemento de diferenciação a ser destacado não foi mencionado explicitamente pelos estudiosos que analisamos, mas nos chamou a atenção ao compararmos os relatos sobre o desenvolvimento do futebol na Argentina e no Brasil e seu papel nas representações identitárias nacionais desses países. Trata-se da apropriação, já desde esses momentos iniciais, por parte dos diferentes governos brasileiros, da popularidade do futebol para associá-la às suas imagens. No Brasil, Gastaldo (2014)

\footnotetext{
${ }^{32}$ ARCHETTI, E. P. Masculinity and football: the formation of national identity in Argentina. In: GIULIANOTTI, R.; WILLIAMS, J. (Ed.). Game without frontiers: football, identity and modernity. Aldershot: Arena, 1994. p. 224-244.
} 
pontua que desde pelo menos o campeonato Sul-Americano de futebol de 1919 o Estado brasileiro apoia e reforça oficialmente sua relação com a seleção brasileira, tentando convertê-la em "um símbolo informal da nacionalidade" (GASTALDO, 2014: 268).

Helal (2014, p. 9) aponta o vínculo entre a prática e os discursos acadêmicos e jornalísticos. Segundo ele, a ideia do Brasil como o "país do futebol" foi uma construção social efetuada por jornalistas e intelectuais a partir dos anos 30, um momento em que se consolidava o "estado-nação" brasileiro, em que se efetuavam formulações acadêmicas sobre a nossa sociedade e que coincide com o projeto nacionalista e integracionista do Estado Novo comandado por Getúlio Vargas. Foi durante seu primeiro governo, aliás, que se deu a profissionalização do futebol no Brasil. A partir de 1933, os jogadores de futebol tornaram-se trabalhadores o que inaugurou uma nova era para o esporte no Brasil e "deu às classes pobres uma nova e imensa possibilidade de ascensão" (GUTERMAN, 2014, p. 81). A Copa de 1938, já na vigência do Estado Novo, ofereceu a Vargas a possibilidade de incorporar definitivamente o futebol à sua agenda e capitalizar sua imagem às custas do desempenho da seleção. A seleção participou com o apoio de todo o aparato governamental e sob a proteção de Alzira Vargas, filha de Getúlio, como sua madrinha.

Mas Vargas não foi o único, a prática continuou e entre 1958, primeiro título do Brasil na Copa e o tricampeonato brasileiro de 1970 os brasileiros passaram a acreditar que eram mesmo o país do futebol. Buscamos em Franco Júnior (p. 135) um resumo desse período, que começa com a descrição do retorno da seleção da Suécia em 1958 (grifos nossos):

De volta ao Brasil, a seleção desembarcou no aeroporto do Galeão e desfilou sobre um veículo do corpo de bombeiros ao som da marchinha "A taça do mundo é nossa", cantada à exaustão pela multidão ensandecida nas ruas do rio de Janeiro. No dia seguinte à conquista, Nelson Rodrigues destacava na imprensa as atuações individuais de Zagallo e Pelé e as qualidades morais de Didi. Os jogadores eram tratados como heróis da pátria. $\mathrm{E}$ o futebol reconhecido como uma feição inseparável da alma brasileira.

O bicampeonato em 1962 no Chile, assim com a dupla conquista da Taça Libertadores da América do do Mundial Interclubes por parte do Santos FC em 1962 e 1963, ratificou a avaliação de que o Brasil tinha o melhor futebol do mundo.

Como podemos ver pelos trechos que destacamos, o construto "Brasil, país do futebol" naquele momento estava sólido e vigente e o tricampeonato em 1970 no México só viria a reforçá-lo. 
Voltando à Argentina, nesse país a expansão e popularização do futebol se deu ancorada nos bairros. Os times nasceram vinculados a essa territorialidade, o que podemos comprovar no nome de alguns clubes que trazem a marca de sua origem como o Boca Juniors, San Lorenzo de Almagro, Racing de Avellaneda. É a partir dos bairros que se estabelece a noção de pertencimento e ao mesmo tempo de alteridade, quando dos enfrentamentos. Não encontramos na bibliografia consultada um movimento tão forte de apropriação, por parte dos governantes argentinos, dos valores do futebol nesse momento de popularização e expansão do esporte. Excluímos desse raciocínio a Copa de 1978 na Argentina, realizada sob plena ditadura militar e que sim, serviu para mascarar uma série de atrocidades que aconteciam nos porões do poder.

Essa diferença também foi observada por Russo (2013, p. 59) que em sua dissertação de mestrado aponta que na Argentina, "as relações identitárias envolviam times e bairros como uma unidade da qual o torcedor também fazia parte" e que no Brasil, embora as rivalidades existissem - especialmente no eixo Rio-São Paulo "o processo de unidade nacional proposto pelo governo Vargas fez com que essas rivalidades fossem minguando em detrimento de um corpo maior, como era a seleção brasileira”. De nossa parte, acrescentamos que Vargas, como vimos anteriormente, incluiu o futebol estrategicamente em seu projeto de união nacional e de construção de uma imagem de grandiosidade do Brasil, porém não foi o único a fazê-lo.

Exposta assim em grandes linhas a chegada e popularização do futebol na Argentina e no Brasil, bem como seu papel nas respectivas construções identitárias, passaremos a discorrer sobre o papel que as Copas do Mundo têm na afirmação das identidades nacionais. 


\section{Copa do Mundo e identidades nacionais}

Retomando a reflexão inicial sobre identidade, recordemos com os autores citados que a identidade não é algo fixo e imutável e que está sempre submetida a forças que tendem a desestabilizá-la. Na contemporaneidade, no que se refere às identidades nacionais essa tensão tornou-se muito mais presente, em função de diversos fenômenos. Guedes (2014) por exemplo, destaca que, no final do século XX, os processos decorrentes da atuação de empresas transnacionais e a intensa e rápida troca de informações possibilitada pela evolução dos meios de comunicação fez se reproduzirem estilos de vida e produtos mundo afora, o que termina por apagar ou deslocar marcas de identificação ou pertencimento. A mesma autora destaca que aumentou significativamente o número de espaços de valorização das nações e de recriação das identidades nacionais. As competições esportivas, em especial as do futebol "transformaram-se em verdadeiros rituais de elaboração e reafirmação de identidades" e as Copas do Mundo, consequentemente, podem ser consideradas como "rituais quadrienais não apenas de celebração das nações, mas também de sua constante reinvenção" (Guedes, 2014:58). Juntamente com suas seleções, entram simbolicamente em campo os estilos de cada país: o futebol-arte brasileiro, a gambeta argentina, a técnica dos alemães. No caso do Brasil, nos períodos que antecedem as Copas do Mundo, a mídia e a publicidade se apropriam e intensificam o sentimento de união em torno de um só objetivo e, por conseguinte, a identificação de ser brasileiro com a seleção nacional e com torcer pelo Brasil. Conforme a autora (2014, p. 59):

São incontáveis as propagandas que exaltam o sentimento nacional, colaborando na construção das representações coletivas sobre um Brasil mestiço, misturado, unificado pelo seu futebol, representado como único e peculiar. Amalgamando o "povo brasileiro" à seleção nacional, a alquimia se completa.

Em outro ponto de vista a respeito da Copa do Mundo de futebol, Helal (2014, p. 9) aponta que a tendência à globalização da cultura que assistimos na primeira década deste milênio tem nos esportes um "veículo de encontro", de apropriação entre os diferentes estados-nação. O jogador que veste a camisa da seleção defende as cores de times estrangeiros e representa também as empresas que os patrocinam. As marcas - em especial as de materiais deportivos - estão praticamente amalgamadas com o fenômeno esportivo. Alguns clubes europeus converteram-se em fenômenos mundiais alavancados 
pelas transmissões em tempo real de seus jogos pela televisão. No caso do Brasil especificamente, segundo o autor esse "proceso de desterritorialización del ídolo y del fútbol crea un nuevo proceso de identidad cultural" que estaria transformando a identidade nacional brasileira sintetizada como narrativa homogênea na ideia de "pátria em chuteiras" e fazendo-a perder muito de sua carga simbólica (HELAL, 2014, p. 9).

Entendemos que os dois posicionamentos são válidos. Na contemporaneidade também aprendemos a aceitar a complexidade dos fenômenos que analisamos e a impossibilidade de apreendê-los como unos e explicáveis por relações biunívocas de causa e efeito.

Resumindo o aqui exposto e circunscrevendo-o ao nosso estudo, compartilhamos da visão de Guedes (2006, p.128) e vemos o futebol como um significante privilegiado para explorar discursivamente a construção em torno de identidades nacionais na Argentina e no Brasil. Visão que acreditamos ter fundamentado com nossa exposição a partir das fontes bibliográficas. Por conseguinte, os eventos das Copas do Mundo de Futebol, convertem-se em cenários em que os países são reificados em suas seleções e entram em cena diferentes representações simbólicas a respeito das identidades nacionais. Nesses momentos distintos atores sociais, instituições e discursos operam em relação de forças desigual. Isto posto, nosso interesse como pesquisadora é analisar como essa complexidade se manifesta discursivamente num gênero específico, as tiras cômicas publicadas durante dois eventos da Copa do Mundo e que sentidos e posicionamentos circulam discursivamente nesse campo discursivo. 


\section{PARTE 2 - SOBRE TIRAS CÔMICAS, JORNAIS, VITÓRIAS E DERROTAS}

\section{CAPÍTULO 4 - O quadro cênico}

\section{Tiras cômicas em jornais diários: uma cena genérica, duas cenas englobantes}

O objetivo deste capítulo é descrever o que Maingueneau $(2001,2010)$ classificou como o quadro cênico na cena da enunciação de um gênero discursivo, a saber, sua cena englobante e sua cena genérica. Como explicitado no Capítulo 1, que trata da Fundamentação Teórica, Maingueneau (2001, 2006, 2010) entende como cena englobante o tipo de discurso ao qual pertence um texto. Essencialmente, trata-se de localizá-lo dentro do vasto espectro composto pelos diversos setores da atividade social, cada um deles com um dispositivo de comunicação particular que por sua vez implica lugares, papéis, um canal, temas etc... particulares. Ainda segundo o autor, a noção de cena englobante nos diz "que certo número de gêneros do discurso partilha do mesmo estatuto pragmático e que a apreensão de um texto ocorre por referência a esse estatuto" (2006, p. 252). Já a cena genérica diz respeito às características que os textos adquirem em sua manifestação como gêneros discursivos. Nas atividades discursivas em que nos engajamos como sujeitos, nos confrontamos com gêneros que implicam rituais linguageiros específicos. Cada gênero discursivo implica um contexto específico com "papéis, circunstâncias (em particular, um modo de inscrição no espaço e no tempo), um suporte material, uma finalidade etc." (MAINGUENEAU, 2008b, p. 116). O autor entende que essas duas "cenas" compõem em conjunto "um espaço estável no interior do qual o enunciado ganha sentido", seu quadro cênico, o "espaço do tipo e do gênero do discurso" (idem).

Em nossa interpretação, as tiras cômicas, na abordagem que delas fazemos neste trabalho, situam-se na intersecção de dois tipos de discurso: o jornalístico e o humorístico. Nesse sentido, com base em Charaudeau (2015), entendemos que como um gênero que integra os jornais diários, as tiras cômicas de produção local na Argentina e no Brasil participam também de uma das atividades discursivas que caracterizam alguns dos gêneros jornalísticos, a saber, aquela que consiste em comentar os fatos que se produzem no mundo, mas na chave do humor. Dessa forma, mediante o humor problematizam acontecimentos, mostram visões, aspectos subjacentes que o leitor é chamado a interpretar e aos quais pode aderir ou não. No caso de que nos ocupamos, como nosso 
interesse é o discurso, a dimensão humorística das tiras - a que se realiza discursivamente - terá mais peso, porém não deixaremos de apreendê-las como um gênero cujo suporte é um jornal diário e dentro do qual desempenham um papel e têm um estatuto pragmático.

Essa decisão metodológica responde ao fato de que em nosso recorte trabalhamos exclusivamente com produções publicadas nas páginas dos jornais diários ${ }^{33}$, o que, como apontaram Gatti e Salgado (2013), repercute na dispersão desses gêneros no tempo. Ao considerá-las dessa forma, estamos também abarcando o fato de que carregam consigo marcas da história em sua enunciação não só no que se refere a acontecimentos, mas também no que se refere a valores e concepções próprias de um momento histórico (idem, p. 519). De nossa parte, acrescentaríamos que carregam não só marcas do tempo-espaço de sua enuciação, como, mais profundamente, marcas da historicidade de sua fixação como gênero na respectiva espacialidade social, como já mencionamos no primeiro capítulo desta tese.

Tendo já discorrido sobre a presença do humor nas tiras cômicas no capítulo 2 deste trabalho, neste nos debruçaremos sobre a relação entre as tiras cômicas e os jornais diários e, especialmente, como se deu sua estabilização como gênero na Argentina e no Brasil.

$\mathrm{Na}$ direção contrária à que normalmente é seguida, partiremos da noção mais particular para o mais geral. Primeiramente refletiremos sobre as características das tiras cômicas enquanto um gênero discursivo, ou seja, sua cena genérica. Uma vez que nosso interesse não incide exatamente sobre a caracterização das produções do campo que delimitamos em nosso trabalho, partiremos de pesquisas e descrições já realizadas sobre as tiras cômicas, delimitando como essas reflexões são mobilizadas em nosso trabalho.

O segundo momento terá um pouco mais de fôlego, pois pretendemos contrastar a forma como se deu a implantação do gênero na Argentina e no Brasil, bem como refletir sobre papel que os dois veículos com os quais trabalhamos desempenham no campo dos quadrinhos e do humor gráfico. Começaremos o percurso abordando a origem das tiras cômicas nos Estados Unidos, em seguida discorreremos sobre a sua inserção na imprensa gráfica da Argentina e no Brasil para depois compararmos ambas as situações. Nesse percurso, tocaremos também na importância que os jornais com que trabalhamos têm na historicidade do gênero tira cômica em seus respectivos países.

\footnotetext{
${ }^{33}$ Esclarecemos que para a reprodução de algumas imagens das tiras Clemente nos valemos de sua publicação em uma coletânea, porque a qualidade da imagem que obtivemos ao fotografar o jornal era ruim. Reforçamos, no entanto, que as produções haviam sido previamente publicadas no jornal Clarín.
} 


\section{Aspectos formais do gênero tiras cômicas}

Em um livro em que se descrevem vários gêneros e pensado para o ensinoaprendizagem de língua materna, Mendonça (2010) se dedica a discutir as histórias em quadrinhos e, a partir delas, as tiras. A autora não usa o termo tira cômica, mas, sim, tiras e as vê como um subtipo das histórias em quadrinhos (doravante HQs). A autora assinala que embora as HQs sejam visualmente muito fáceis de identificar, o mesmo não se dá no que se refere a seu funcionamento discursivo. Partindo de considerações a respeito do tipo textual, mecanismos e recursos tecnológicos usados, relação fala e escrita e domínio discursivo, ela propõe definir as HQs "como um gênero icônico-verbal narrativo cuja progressão temporal se organiza quadro a quadro" que tem como elementos típicos "os desenhos, os quadros e os balões e/ou legendas, onde é inserido o texto verbal" (p. 215). Assim, as HQs estariam inseridas em "uma verdadeira constelação de gêneros não verbais ou icônicos verbais assemelhados" (p. 212) entre os quais se encontram a caricatura (que deforma as características marcantes do objeto representado), a charge (que alia as características da caricatura a um fato jornalístico), o cartum (surgido depois da charge, expressa ideias e opiniões e é mais atemporal que ela), as próprias HQs (sequências narrativas com vários quadrinhos) e as tiras.

No que concerne à relação fala e escrita, a autora (p. 211) recorre a Marcuschi (2008) e aponta que, no continuum de gêneros textuais proposto por aquele autor, as HQs, apesar de serem realizadas no meio escrito, buscam reproduzir a fala. Para fazê-lo, além dos diversos recursos gráficos como os tipos de balões, os apêndices, os tipos de letras etc, o texto verbal dos quadrinhos traz diversas marcas da oralidade como o uso constante de interjeições, reduções vocabulares etc. Apresentamos a seguir dois exemplos que ilustram essa característica.

No primeiro (figura 6), da tira Clemente, de Caloi, os personagens são a Mulatona e Clemente. Nela, um dos recursos humorísticos é justamente a tentativa de reproduzir um "sotaque" na fala da Mulatona na grafia das palavras ió (yo), iá (ya), trahe (traje), tapaohera (tapaojera) que a faria se assemelhar ao do espanhol falado em Cuba. Na fala de Clemente, também encontramos reduções como fulbo (fútbol) e pá (para) típicas do registro coloquial. O desfecho inesperado que finaliza a tira e dá o efeito de piada se dá porque a Mulatona altera a expressão "plantarle cara a las contrarias" (desafiar, resistir) com "pintarle la cara a las contrarias". 


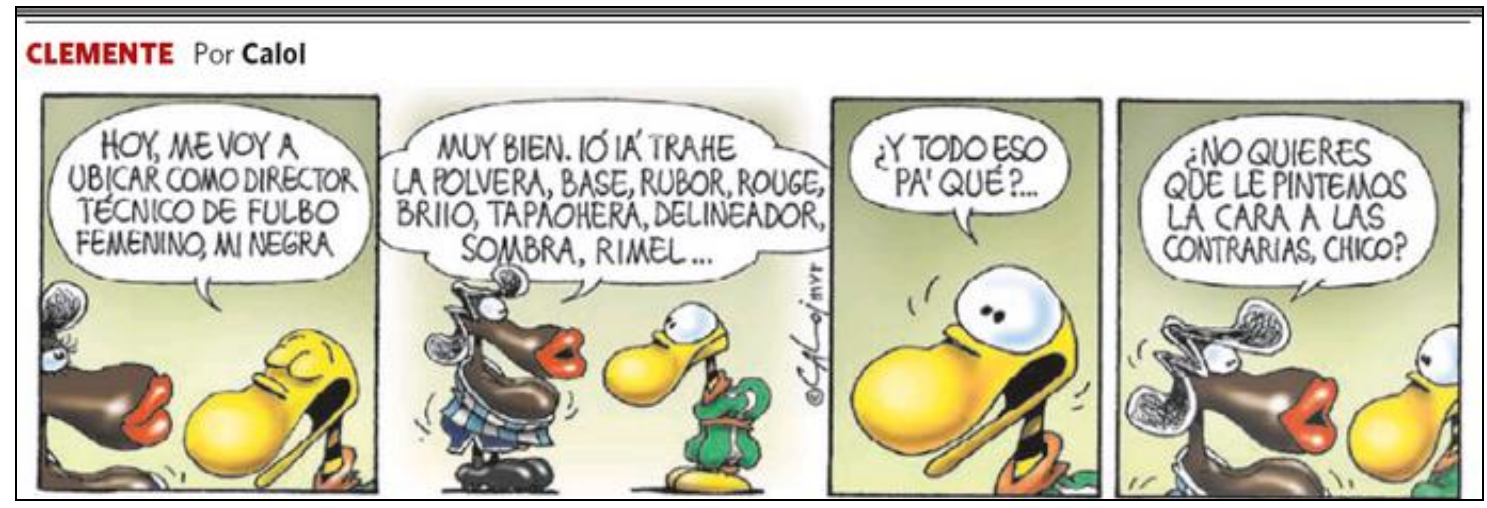

Figura 3 - Clemente - Pintarle la cara - Fonte: Clarín - 13/06/2010

No segundo exemplo (figura 7), a tira Daiquiri, de Caco Galhardo, temos o personagem Chico Bacon, o mais baixo, interagindo com outro, que é um participante frequente das tiras, mas cujo nome não é mencionado. Ambas as falas trazem diversas marcas de oralidade e de coloquialidade, como, por exemplo, as formas verbais tá (está) e tô (estou) e o diminutivo nervosinho. Além disso, a expressão “tá nervosinho(a)” é usada em contextos coloquiais com uma entonação característica que marca uma atitude de escárnio com o outro, que se pode perceber como reproduzida na tira pelo riso insinuado do personagem que a diz. No balão que indica a fala de Chico Bacon, por sua vez, as letras aparecem em negrito que podem representar uma entonação categórica e lacônica e inclusive um falar num tom mais alto.

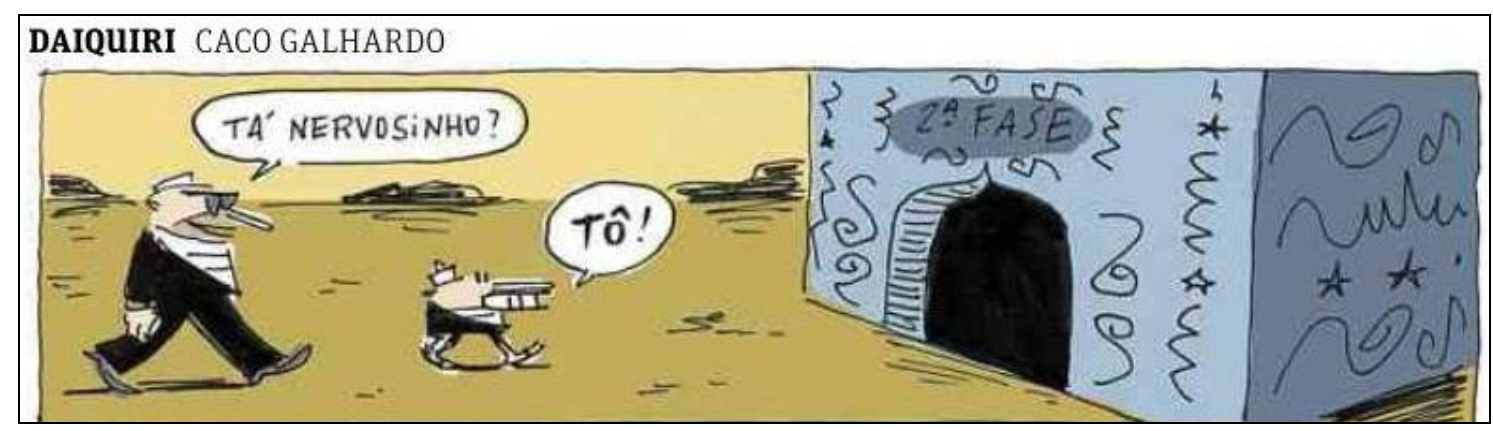

Figura 4 - Daiquiri - Nervosinho - Fonte: Folha de S. Paulo em 24/06/2014

Voltando à classificação das tiras por Mendonça (2010), a autora conclui sua exposição a respeito do gênero destacando que como um subgrupo das HQs, as tiras guardam com essas últimas algumas semelhanças mas têm também suas especificidades: são mais curtas - até quatro quadrinhos, normalmente - e podem ser sequenciais (capítulos de narrativas maiores) ou fechadas (um episódio por dia). As fechadas, 
segundo a autora, se subdividem em dois subtipos, a saber: as tiras-piada, com temática humorística e que utilizam as mesmas estratégias das piadas; e as tiras-episódio, quando o humor explora o desenrolar de um tema em uma situação determinada que realça as características das personagens.

Ramos $(2009,2011)$ aborda tanto a caracterização do gênero tira cômica utilizando a nomenclatura que adotamos -, como sua localização no universo das produções em quadrinhos com mais profundidade e faz uma proposta com base na noção de hipergênero de Maingueneau (2006). Pelo seu detalhamento no que concerne às tiras, é a que adotaremos em nosso trabalho. Segundo essa proposta, os quadrinhos constituem um hipergênero, um grande rótulo que abriga diferentes gêneros autônomos que partilham de determinadas características, entre as quais ter a tendência de serem narrativas que ocorrem em um ou mais quadrinhos, terem ou não personagens fixos, de usar imagens desenhadas (embora haja casos de uso de fotografias) e de compartilhar recursos próprios da linguagem quadrinística (balões, onomatopeias, linhas cinéticas etc). Fazem parte desse hipergênero as charges, os cartuns, as tiras cômicas e outras produções em quadrinhos que tenham "em comum o uso da linguagem dos quadrinhos para compor um texto narrativo dentro de um contexto sociolingüístico interacional” (RAMOS, 2009:20). Nesse sentido, o autor entende que as ilustrações e as caricaturas não fazem parte do hipergênero quadrinhos, pois não constituem narrativas. Sua classificação vai ao encontro do recorte que efetuamos na delimitação do campo, no sentido bourdieusiano, em que situamos as tiras cômicas, a saber, do humor gráfico e quadrinhos. Embora a questão não esteja no cerne de nosso trabalho, entendemos que as caricaturas e as ilustrações poderiam estar inseridas dentro do rótulo humor gráfico.

Ramos (2011, p.106), sem a intenção de propor um modelo fixo, detalha certas características das tiras cômicas enquanto gênero, a saber:

- formato fixo e padronizado que corresponde a um retângulo, que pode ou não ser dividido em várias vinhetas - termo que usaremos neste trabalho - ou quadrinhos. Esse formato permanece inalterado desde o que se conhece como o advento da primeira tira cômica e, como já mencionamos, condiciona várias outra características do gênero;

- tendência a que esse formato seja horizontal, equivalente ao de uma ou duas tiras, embora possamos encontrar também tiras na horizontal;

- tendo em vista a limitação do formato, tendência a ter poucos quadrinhos, de um a quatro, embora haja casos de uso de vários quadrinhos, principalmente em tiras duplas ou de dois andares; 
- tendência ao uso de imagens desenhadas, mas também se observam ocorrências de fotografias ou colagens;

- normalmente têm na parte de cima o título da tira e o nome do autor quando publicadas em jornais e suplementos, dado que é omitido quando publicadas em coletâneas, pois a autoria já consta na capa da obra;

- personagens que podem ou não ser fixos;

- predomínio de sequência narrativa, com uso de diálogos;

- normalmente têm temas humorísticos;

- tendência a um desfecho inesperado, que gera o humor;

- geralmente apresentam uma narrativa com começo, meio e fim; ou ao menos um antes e um depois;

- a narrativa pode ter continuidade temática em outras tiras.

Para concluir, apresentamos na figura abaixo um exemplo que ilustra bem o exposto anteriormente. Trata-se de uma tira do personagem Geraldão, de autoria do cartunista Glauco, publicada na Folha de S. Paulo durante a Copa de 2002 realizada entre o Japão e a Coreia do Sul.

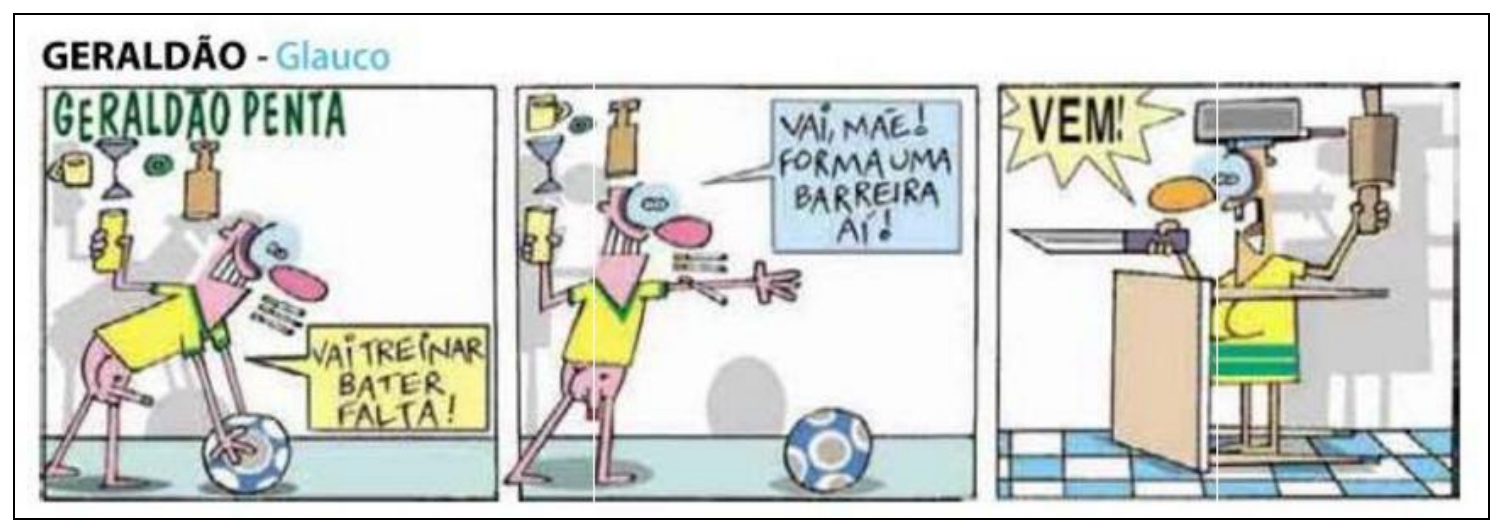

Figura 5 - Geraldão - Barreira - Fonte: Folha de S. Paulo em 19/06/2002

Trata-se de uma produção com um formato canônico, na horizontal e uma narrativa que inicia e se encerra em três vinhetas. Há predomínio de diálogos e um desfecho inesperado que leva ao humor. É uma tira de personagem fixo e seu humor reside em grande parte justamente nas características desse personagem, pautadas no exagero caricatural com muito nonsense nas situações retratadas. Também vemos na parte de cima o nome do autor e o título da tira. Tal como todas as outras que Glauco publicou durante o período de realização do campeonato, continha o subtítulo Geraldão Penta 
dentro da primeira vinheta, em alusão ao título que a seleção brasileira estava disputando, e que efetivamente ganhou, ou seja, havia uma continuidade temática entre as produções.

\section{Marcos histórico das tiras cômicas}

\subsection{As origens}

É impossível dissociar as tiras cômicas dos jornais, pois foi o meio onde nasceram, nos Estados Unidos no início do século XX. Como assinala Magalhães (2006, p. 9), trazer ilustrações para os jornais foi uma estratégia utilizada para atrair mais leitores e as tiras, por agregarem também o elemento humorístico à imagem, serviram para consolidar e ampliar o público. A maioria das características do gênero (formato, texto sintético, humor) se deve às restrições do meio em que se deu sua gênese bem como a seu propósito inicial: atrair e entreter.

Os pesquisadores de quadrinhos consultados destacam que há dois nomes e datas diferentes quando se trata de determinar a origem da tira cômica (MAGALHÃES, 2006; MORETTI, 2003; SILVA, 2010). Alguns estudos apontam A. Piker Clerk, de autoria de Clare Briggs, como a primeira tira cômica a ser publicada em um jornal, embora não diariamente, mas sim três vezes por semana. O ano era 1903, e o jornal, o Chicago American. O título era o nome do protagonista, um sujeito magro, sem queixo, narigudo, de olhos esbugalhados e aficionado a corridas de cavalos (Figura 6). A tira saía na página de turfe do jornal, normalmente continha um palpite para aposta e seu objetivo era justamente fazer o leitor comprar o jornal no dia seguinte para conferir se a dica dera certo. É preciso lembrar que nesse momento ainda não havia rádio. Segundo Moretti (2003, p. 88), Briggs era melhor como chargista que como desenhista de quadrinhos e às tiras lhes faltava charme, estilo e qualidade nas gags. Assim, a empreitada não vingou e A. Piker Clerk foi cancelada em 1904, tendo durado pouco mais de um ano. 


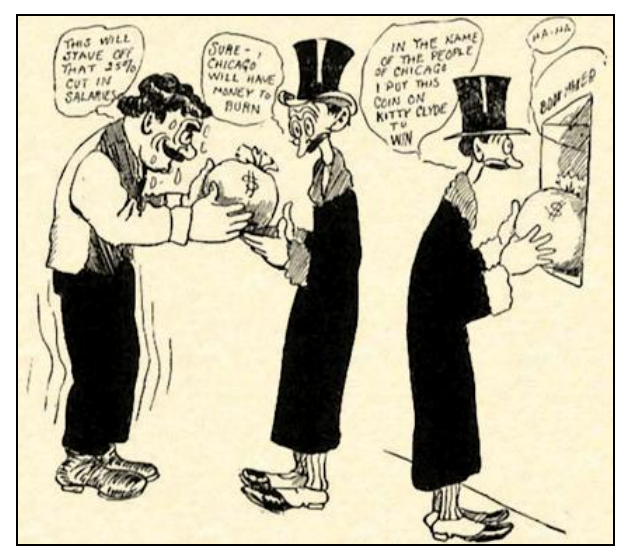

Figura 6: A Piker Clerk

Fonte: http://artesecuencial.com.es/index.php/series/a-piker-clerk/

O segundo título citado como sendo a primeira tira cômica é $M r$. A. Mutt, posteriormente Mutt \& Jeff, de autoria de Bud Fisher. Neste caso o ano era 1907 e o jornal, The San Francisco Chronicle. Inicialmente as histórias eram protagonizadas pelo personagem A. Mutt (Augustus Muttonhead), um homem magro e alto, curiosamente também maníaco por corridas de cavalos, tal como A. Piker Clerk. Em março de 1908, Mutt conheceu Jeff, um baixinho, viraram uma dupla, a tira passou a se chamar Mutt \& Jeff e fez um enorme sucesso. Bud Fisher morreu em 1954, mas Al Smith, seu assistente desde 1932, continuou a desenhar a série até 1980, o que demonstra sua enorme repercussão. Mutt \& Jeff (Figura 7) foi publicada por 75 anos - até 1982 - em jornais locais e estrangeiros, inclusive no Brasil, onde figurou nas páginas de $O$ Estado de $S$. Paulo.

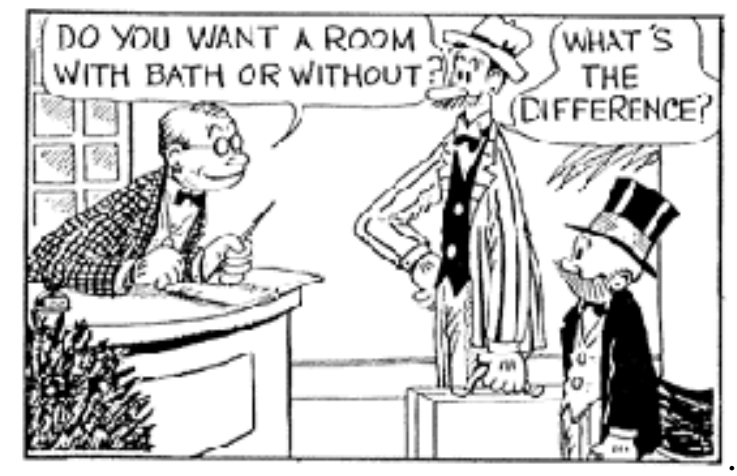

Figura 7: Mutt \& Jeff

Fonte: http://erikcontreras.tripod.com/historia.htm

O sucesso dessa tira incentivou outros autores e surgiram novos títulos. Esse momento histórico coincide com a explosão da imprensa nos Estados Unidos e as necessidades criadas pela publicação diária das tiras cômicas nos jornais, as comics strips, 
levou à criação dos syndicates, as agências distribuidoras que passaram a exportá-las para o mundo. Bibe-Luyten (1985, pp. 22 e 23) registra que a primeira delas foi a International News Service, posteriormente King Features Syndicate, criada em 1912 por William R. Herst, um dos grandes magnatas da imprensa estadunidense. A autora explica que no esquema de distribuição criado por essas agências e em vigor até hoje, os desenhistas são contratados para produzir histórias, submetidas à aprovação prévia, que devem ser enviadas com antecedência para correção e padronização pois, para que possam ser veiculadas e consumidas nas mais diferentes sociedades, as tiras distribuídas pelas agências internacionais não podem tratar de temas relacionados à problemática local, mas, sim, abordar temas universais. Assim, o universo infantil e as relações familiares fornecem os temas mais presentes nessas criações. Voltando ao esquema de produção das agências de distribuição internacionais, após reproduzidas em papel de alta qualidade, as histórias são enviadas para os jornais e editoras que têm contrato com a agência. Esse modelo possibilita a venda das tiras cômicas às editoras e aos jornais por um valor muito baixo, pois o lucro das agências provém da enorme quantidade de tiras vendidas de uma só vez. Para os autores dos países para os quais essas produções são exportadas, no entanto, esse esquema impacta diretamente na remuneração de seu trabalho e em sua sobrevivência, pois é muito difícil conseguir concorrer com os valores praticados pelas agências de distribuição.

Nas primeiras décadas do século XX, as tiras cômicas produzidas nos Estados Unidos chegaram tanto à Argentina como ao Brasil, e é disso que trataremos nos itens seguintes.

\subsection{As tiras cômicas na Argentina durante o século XX}

A publicação das tiras cômicas nos jornais argentinos tem início em 1920, no jornal La Nación (GUTIÉRREZ, 1999, p. 93). No dia 18 de outubro desse ano, o La Nación publicou, no alto da página de anúncios classificados, a tira Bringing up Father, de George McManus, rebatizada de Pequeñas delicias de la vida conyugal. Logo depois, esse mesmo jornal passaria a publicar também Mutt \& Jeff. Gutiérrez (1999, p. 90) classifica como surpreendente o fato, pois o La Nación era um jornal sóbrio e conservador, fundado em 1870 por Bartolomé Mitre, presidente da Argentina entre 1862 e 1868, no qual poucas vezes havia sido incluída uma mera caricatura. Segundo o autor, teria sido mais lógico essa primeira aparição ter se dado no jornal Crítica, que desde sua 
fundação contava com uma ampla cobertura gráfica e publicava numerosas seções fixas de caricaturas, além de naquele momento ser dirigido por Natalio Botana, que havia colaborado na revista humorística P.B.T., publicação dedicada ao humor gráfico que se anunciava como um semanario infantil ilustrado para niños de 6 a 80 años. Conforme informam Martignone \& Prune (2008, p. 37), a publicação de fato desagradou parte do público leitor do La Nación. Em seus protestos, esses leitores argumentavam que a inclusão de uma tira cômica era uma mostra de frivolidade que não combinava com a seriedade do tradicional jornal diário de Mitre. A despeito dessa resistência inicial, as tiras cômicas conquistaram o público, e tanto produções estrangeiras como locais passaram a ocupar as páginas diárias dos principais jornais argentinos: Crítica, La Razón, La Prensa e El Mundo.

Embora não tenha sido o primeiro a publicar tiras cômicas diárias, o jornal Crítica foi sem dúvida o mais importante para a consolidação do gênero nesse meio. Talvez devido à formação de seu já citado diretor, Natalio Botana, a partir de meados dos anos 20 e ao longo dos anos 30 , nele será publicado o melhor da produção local ${ }^{34}$. Ramos (2010, p. 29) narra que foi precisamente nas paginas de Crítica, em 19 de outubro de 1928, na série Aventuras de Don Gil Contento, de autoria de Dante Quinterno, que apareceu pela primeira vez um personagem secundário, inicialmente chamado CuruguaCuriguagüigua, que posteriormente se converteu no índio Patoruzú, um dos mais famosos e queridos personagens dos quadrinhos argentinos.

É importante destacar que mesmo antes da consolidação das tiras cômicas nos jornais diários, já se pode perceber na Argentina o embrião de uma cultura local de produção de quadrinhos e de humor gráfico. Nas páginas das revistas ali existentes nas primeiras décadas do século XX (Caras y Caretas, a já citada PBT, El Hogar, Tit-Bits, Billiken) surgiram vários personagens fixos, alguns cópias de séries estrangeiras, caso de Viruta y Chicharrón, versão argentina de Spareribs and Gravy de George McManus, e outros com traços locais, caso de Don Goyo de Sarrasqueta e El Negro Raúl. O primeiro protagonizava histórias baseadas na situação do país à época, com um tom declaradamente crítico, o segundo estava baseado em um personagem real da fauna portenha $^{35}$.

\footnotetext{
${ }^{34}$ Néstor Gustavo Giunta em La Historia del Cómic en la Argentina $<$ http://www.todohistorietas.com.ar/historia argentina_1.htm〉. Acesso em 20/11/2013.

${ }^{35}$ Néstor Gustavo Giunta em La Historia del Cómic en la Argentina

$<$ http://www.todohistorietas.com.ar/historia_argentina_1.htm>. Acesso em 20/11/2013.
} 
Avançando um pouco mais no fio da história, Martignone e Prunes (2008, pp. 37 e 38) destacam que, embora continuassem a ser publicadas em jornais, foi nas revistas de humor que as tiras cômicas encontraram a plataforma ideal para se desenvolver e chegar ao que se convencionou chamar de era de ouro dos quadrinhos argentinos, as décadas de 30 a 60. Esse período certamente influenciou a geração de quadrinistas seguintes, da qual Quino é sem dúvida, o maior representante. Porém após a bonança dos anos de ouro, os pesquisadores apontam que no final dos anos sessenta houve uma retração no mercado editorial das revistas de humor e um desinteresse dos jornais por produções locais, pois haviam se rendido às facilidades oferecidas pelas publicações estrangeiras que chegavam pelas agências de distribuição (idem, p. 39).

No entanto, é precisamente durante a segunda metade dos anos sessenta e início dos setenta que a Argentina vê nascer um verdadeiro fenômeno em termos de sua transcedência e permanência: as tiras de Mafalda. As histórias de Mafalda e seus amigos, que tornariam Quino conhecido internacionalmente, foram publicadas de setembro de 1964 a junho de 1973, em três veículos diferentes: um jornal e duas revistas. Curiosamente, a tira cômica que influenciou substancialmente os autores das tiras nacionais publicadas posteriormente nos jornais argentinos foi mais publicada em revistas que em jornais. Mafalda surgiu como tira na revista Primera Plana e ali ficou de setembro de 1964 a março de 1965, passou depois a ser publicada no jornal El Mundo (março de 1965 a dezembro de 1967) e finalmente na revista Siete Días Ilustrados (junho de 1968 a junho de 1973) (RAMOS, 2010, p. 19). A relevância e a repercussão da criação de Quino podem ser medidas factualmente: ele deixou de desenhar as histórias de Mafalda há mais de 40 anos, seus personagens, no entanto, continuam vivos e presentes não só na Argentina, como em muitos outros países, hispanofalantes ou não.

\subsubsection{A página de humor do Clarín}

Voltando ao percurso histórico das tiras cômicas nos jornais da Argentina, nos anos 70 um fato crucial mudará completamente o cenário de predomínio de tiras estrangeiras nas páginas diárias e consolidará o espaço das tiras cômicas de produção local nos jornais. A partir de 1973 o jornal Clarín passa paulatinamente a substituir as tiras estrangeiras por séries de artistas nacionais e a publicá-las sempre na contracapa. 
Assim, em $1980^{36}$ deixa de ser publicada a última sobrevivente estrangeira, Mutt \& Jeff, e a página de humor do Clarín passa a pertencer aos autores nacionais. Martignone \& Prunes (2008, p.41) destacam a importância do fato, que emblematicamente marca que "a partir de los años setenta se consolidará en los principales diarios y en el imaginario cultural la idea de una tira nacional fuertemente ligada a la realidad y a la idiosincrasia de los argentinos".

Trata-se de uma ideia de tira cômica que dialogará de modo muito claro com a cultura local e da qual alguns de seus representantes são Fontanarrosa e seu Inodoro Pereyra; Caloi com seu pássaro sem asas Clemente, que conseguiu que o povo contrariasse os militares durante a Copa do Mundo de Futebol de 1978 na Argentina ${ }^{37}$ e, mais recentemente, a exagerada La Nelly de Sergio Langer e Rubén Mira. Nas tiras dessa personagem, que estreou no Clarín em setembro de 2003, é possível estabelecer um vínculo direto entre o noticiário e os temas abordados, suas histórias baseavam-se na realidade diária argentina. Levín (2012, p. 234) sintetiza com muita propriedade as consequências da nacionalização da página de humor do Clarín. Segundo ela:

La resignificación del espacio de humor promovió un vínculo de complicidad entre los lectores y los humoristas de Clarín. Ahora, ambos formaban parte de la misma comunidad simbólica creada en torno al consumo regular del diario que era, por otra parte, la materia prima para la construcción de las tiras y viñetas. Además, la nacionalización creó una cotidiana complicidad entre ambos fundada en la aceptación de un conjunto de códigos culturales y humorísticos que promovió un reconocimiento especular en el otro, mediado por los personajes y situaciones recreadas en las viñetas.

O resultado desse panorama que acabamos de descrever é que os personagens dos quadrinhos e do humor gráfico se tornaram tão presentes na vida cotidiana dos bonaerenses que por iniciativa institucional há hoje na cidade um caminho de estátuas representando uma série desses personagens, trata-se do Paseo de la historieta ${ }^{38}$. A iniciativa tem seu fundamento no incentivo do turismo, de qualquer forma não deixa de

\footnotetext{
${ }^{36}$ O jornal La Nación somente seguiu a iniciativa depois da virada do século: em dezembro de 2007 anunciou que passaria a publicar somente autores nacionais.

${ }^{37} \mathrm{Em}$ 1978, durante a realização da Copa do Mundo na Argentina, os militares proibiram uma manifestação tradicional dos argentinos em estádios de futebol: uma chuva de papel picado. A razão alegada era que isso impressionaria mal os estrangeiros. O personagem Clemente questionou a proibição em suas tiras e durante os jogos os argentinos continuaram jogando papéis picados. O episódio ficou conhecido como la guerra de los papelitos, é descrito com um pouco mais de detalhes no capítulo 5 e na biografia de Caloi que se encontra no Apêndice.

${ }^{38}$ É possível conhecer todo o circuito em https://turismo.buenosaires.gob.ar/es/atractivo/paseo-de-lahistorieta-0.
} 
ter também seu peso para a construção de uma memória ao redor desses personagens e de tudo o que lhes diz respeito.

Retomando nossa discussão sobre o Clarín, o jornal tem formato tablóide ${ }^{39}$, e nele as tiras cômicas ocupam a última página, a contracapa, um local privilegiado em termos editoriais. Embora pareça um detalhe corriqueiro, essa localização acaba impactando a importância que têm as tiras como um dos gêneros que integram um periódico diário. Como destaca Ramos (2016, p. 80), a última página do Clarín funciona como uma segunda capa "ou primeira, a depender do interesse de cada um". Ou seja, nesse jornal "la página de los chistes" (idem) disputa com as manchetes os primeiros olhares dos leitores. Ademais, na exposição dos jornais nas bancas, essa localização das tiras possibilita que elas sejam lidas inclusive por pessoas que não são assinantes e nem leitores do jornal inteiro.

A importância desse lugar é tal, que $\mathrm{Caloi}^{40}$, nome artístico do quadrinista argentino Carlois Loiseau, chega a tematizar a localização. Trata-se da tira Clemente , reproduzida na figura 8. Nela, o personagem discorre justamente sobre "sua" localização no jornal e a consequência disso para que seja lida. Pela pertinência para o ponto que estamos abordando, nos permitiremos uma digressão para comentá-la.

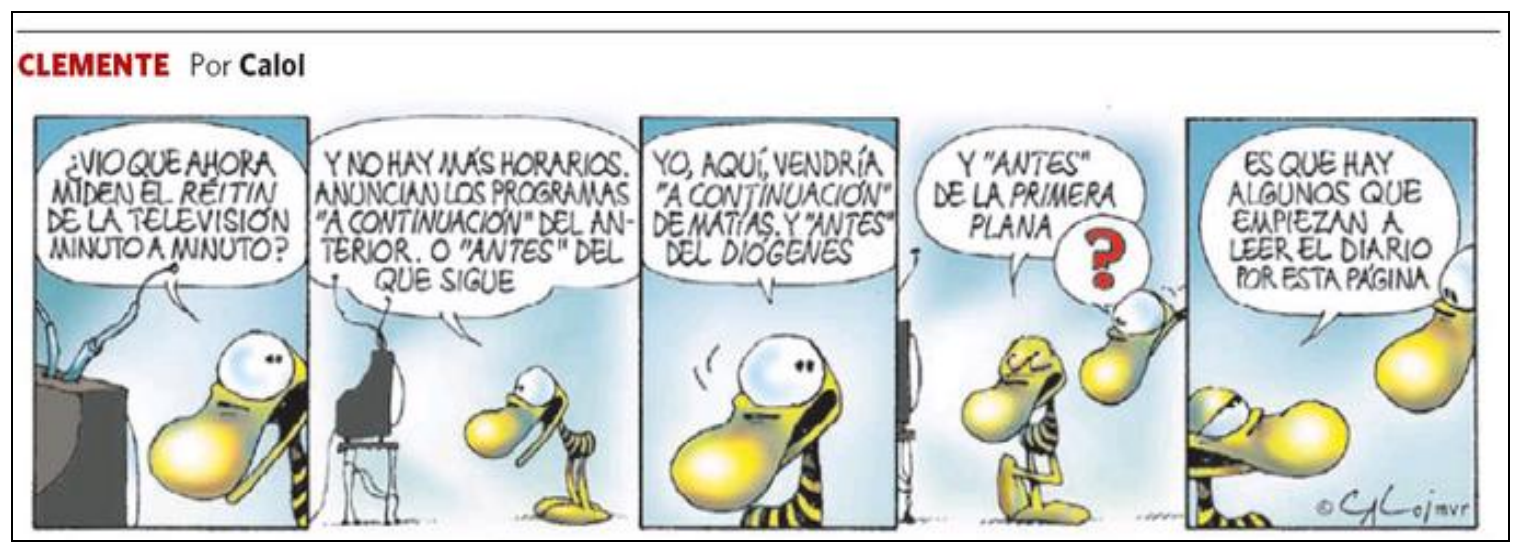

Figura 8 - Clemente - Réitin - Fonte: Clarín de 9 de julho de 2010

\footnotetext{
${ }^{39}$ Segundo o tamanho da folha em que são impressos, os jornais podem ter diferentes formatos. Os mais conhecidos são o standard, o tablóide e o berliner ou berlinense. Conforme informações disponíveis no site http://tipografos.net/glossario/formatos.html (consulta em 10/05/2017), o formato standard tem entre $60 \mathrm{~cm}$ x $38 \mathrm{~cm}$ e $75 \mathrm{~cm}$ x $60 \mathrm{~cm}$, o tablóide, cerca de $38 \mathrm{~cm}$ x $30 \mathrm{~cm}$ e o berliner, cerca de $47 \mathrm{~cm}$ x 31,5 cm. Como podemos notar, essas medidas não são rígidas e têm variado, inclusive seguindo necessidades de padronização do mercado para publicação de anúncios.

${ }^{40}$ No Apêndice, encontram-se as biografias dos autores cujas tiras foram analisadas, bem como uma breve descrição de suas produções.
} 
Temos nesta tira uma sequência de cinco vinhetas com o mesmo cenário: o personagem Clemente diante de um aparelho de televisor e sozinho até a terceira vinheta. Na primeira, o olhar do personagem se dirige para fora da tira e no balão que representa sua fala encontramos um enunciado em forma interrogativa. Assim, constrói-se uma cenografia, nos termos de Maingueneau (2001, 2010), em que o leitor virtual é interpelado e passa a interagir com o personagem Clemente em uma espécie de diálogo, em que só o personagem "fala". A articulação entre imagem e texto instaura uma cenografia de conversa rotineira a respeito de um tema do noticiário cotidiano. Nela, Clemente primeiramente comentará que o réitin, sua maneira de referir-se ao rating, ou seja, os índices de audiência de um programa, passara a ser medido minuto a minuto e que os programas não eram mais anunciados a partir dos horários, mas, sim, com indicações como “ “a continuación del anterior'” ou “ 'antes' del que sigue”. Na terceira vinheta, o personagem transfere esse novo parâmetro para sua própria situação na sequência das tiras da página do Clarín. Comenta que viria “' a continuación' de Matías, y 'antes' del Diógenes”. Note-se que no enunciado o advérbio antes e a locução adverbial a continuación estão entre aspas, elementos que marcam no fio do discurso a irrupção de outras vozes, no caso, a das emissoras de televisão para anunciar sua programação. Na quarta vinheta, há uma mudança na expressão corporal do personagem, que aparece de olhos fechados, com a perna cruzada, o que parece conferir-lhe um tom de superioridade ao acrescentar que viria também “ “antes' de la primera plana”, ou seja, antes da primeira página do jornal. Surge então o outro personagem, que vamos chamar Clemente alto, de quem só vemos o rosto e que auxiliará na resolução humorística da tira. Desse Clemente alto vemos sair um balão de fala com um sinal de interrogação, na indicação de dúvida ou pergunta. Na quinta e última vinheta, o primeiro Clemente conclui, novamente com um olhar de superioridade, indicado pelas pálpebras a meio cerrar, que viria antes da primeira página porque algumas pessoas começam a ler o jornal pela página em que se encontra, usando para isso o dêitico "esta". E começariam por sua tira, porque o verbo vendría presente no enunciado do balão de fala da quarta vinheta retoma o pronome sujeito yo que foi explicitado na terceira vinheta. Interpretamos que a isso se deve o ar de superioridade porque essa constatação subverte completamente o status das tiras na escala de importância das páginas do jornal. A primeira página recebe atenção diferenciada por ser “a expresão imagética que primeiro impacta o leitor” (FERREIRA JUNIOR, 2003, p.15). 
Trata-se do espaço mais valorizado do jornal, tanto é assim que passou inclusive a ser comercializada em formato de sobrecapas publicitárias ${ }^{41}$. Pela tira de Clemente podemos constatar, por conseguinte, que o autor explicita não só o protagonismo da página de los chistes do Clarín, mas o da sua própria criação, pelo menos naquele momento.

Atualmente, no entanto, após quase quarenta anos da iniciativa de só publicar autores locais, notadamente após o falecimento de Caloi em 2012 e a interrupção de $L a$ Nelly em março de $2016^{42}$, as produções da contracapa do Clarín mostram certo desgaste e já não refletem claramente as características indicadas por Martignone \& Prunes (2008). Em entrevista que nos foi concedida por email ${ }^{43}$, Martignone nos comentou que os autores que publicam atualmente na página

no se meten demasiado (ni demasiado directamente cuando lo hacen) con la actualidad (al igual que ocurre con el "Macanudo" de Liniers en La Nación). No es que sea necesario hacerlo, pero cuando las tiras llevan muchos años publicándose suele ser difícil mantenerlas solo con su "universo interno".

Finalizamos assim nossa exposição com relação à estabilização das tiras cômicas como gênero na Argentina e passaremos a abordar o contexto brasileiro onde a disputa das tiras cômicas de produção local versus as estrangeiras teve resultado completamente diferente. Até hoje os artistas nacionais competem por espaço nos jornais com as produções estrangeiras e em muitos casos, perdem. Nosso objetivo no próximo item é mostrar como esse cenário se desenhou.

\footnotetext{
${ }^{41}$ Para mais detalhes a respeito da importância da primeira página, além da obra citada de José Ferreira Junior, remetemos o leitor ao texto de apresentação da obra Primeira Página: Folha de S. Paulo (São Paulo: Publifolha, 2000) de autoria de Nicolau Sevcenko.

${ }^{42}$ A tira havia deixado de ser publicada na contracapa em 26/09/2010, quando passou para uma página interna no caderno La Ciudad. Em entrevista ao blog Al rescate! Comics em maio de 2016, Langer aponta motivos políticos para a demissão, pois Macri, o candidato apoiado por Clarín, constantemente era alvo de sátiras nas histórias de La Nelly. Mais detalhes em http://alrescatecomics.blogspot.com.br/2016/05/sergiolanger-nelly-estaba-satirizando.html. (Agradecemos a Hernán Martignone a indicação dessa entrevista.)

${ }^{43}$ A íntegra da entrevista, realizada por email em 26/07/2017, está reproduzida no Apêndice.
} 


\subsection{As tiras cômicas no Brasil durante o século XX}

Algo que salta aos olhos do pesquisador que queira analisar o percurso histórico das tiras cômicas em jornais do Brasil é a pouca informação que se tem organizada e publicada a esse respeito, especialmente sobre seus primórdios. Assim, diferentemente da Argentina, o início da publicação de tiras cômicas com periodicidade em jornais brasileiros não está documentado com precisão. No levantamento bibliográfico efetuado, a referência cronológica mais distante a algo que poderia ser classificado como tira cômica em um jornal encontramos em Silva (2010, p. 69). Segundo o autor, nos seus primeiros anos, o jornal $O$ Globo trazia quadrinhos de autoria brasileira com narrativas em formato parecido ao que havia surgido nas páginas dos jornais no exterior. Exemplifica com uma publicação datada de 24/7/1926, uma tira cômica na qual se anunciava uma lâmpada da marca Edison Ideal, reproduzida a seguir na figura 9. Segundo esse autor, era de autoria de Valmir e trazia uma nova história a cada semana.

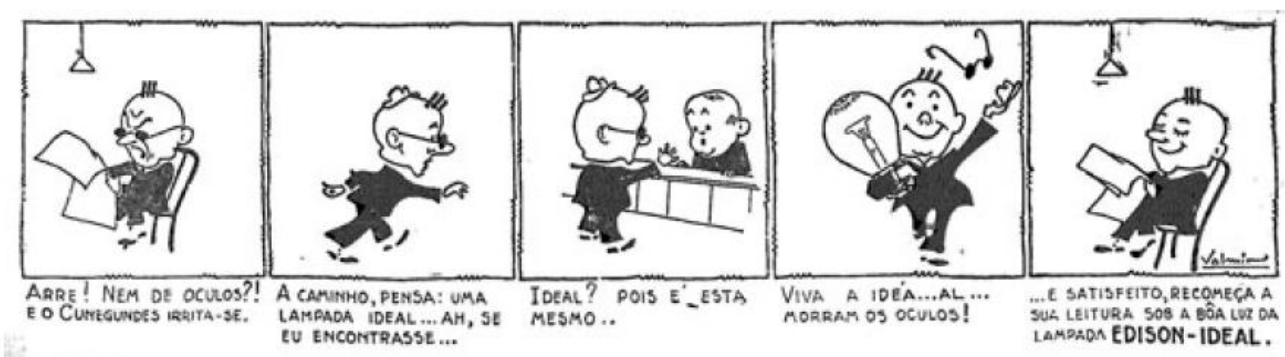

Figura 9: tira publicada em $O$ Globo em 24/7/1926.

Fonte: SILVA, F. L. C. M. O Quadro nos Quadrinhos. Rio de Janeiro: Multifoco, 2010, pp. 69.

O mesmo autor afirma que no início de maio de 1934 foi publicada a primeira história em quadrinhos estrangeira em $O$ Globo (p. 72). Trata-se de A namorada do pelle vermelha (He done her wrong) de Milt Gross. É importante observar, no entanto, que não se tratava de uma história em quadrinhos no sentido estrito do termo, e tampouco de uma tira cômica, mas sim de uma narrativa gráfica, uma história sem palavras nem diálogos, que se assemelhava ao cinema mudo. A obra foi publicada desmembrada em tiras, com quadros desiguais e legendas.

Ainda segundo Silva (2010, p. 75), a partir de 1940, o jornal $O$ Globo começou a veicular tiras diárias estrangeiras, fornecidas pelas agências de distribuição. O número de tiras foi aumentando progressivamente e culminou em uma página inteira de tiras em 1950, passando a duas em 1953. Entretanto, observando detidamente a página do jornal que o autor reproduz em sua obra e que incluímos a seguir, na Figura 10, nota-se que há 
somente uma que poderia ser considerada tira cômica, a série Bringing up Father, traduzida no jornal por Vida Apertada, e também conhecida por Pafúncio e Marocas. As outras produções são histórias de aventuras publicadas em tiras, como se fossem capítulos de novelas, um gênero que Ramos classifica como tiras seriadas ou tiras de aventuras (2009, p. 25).

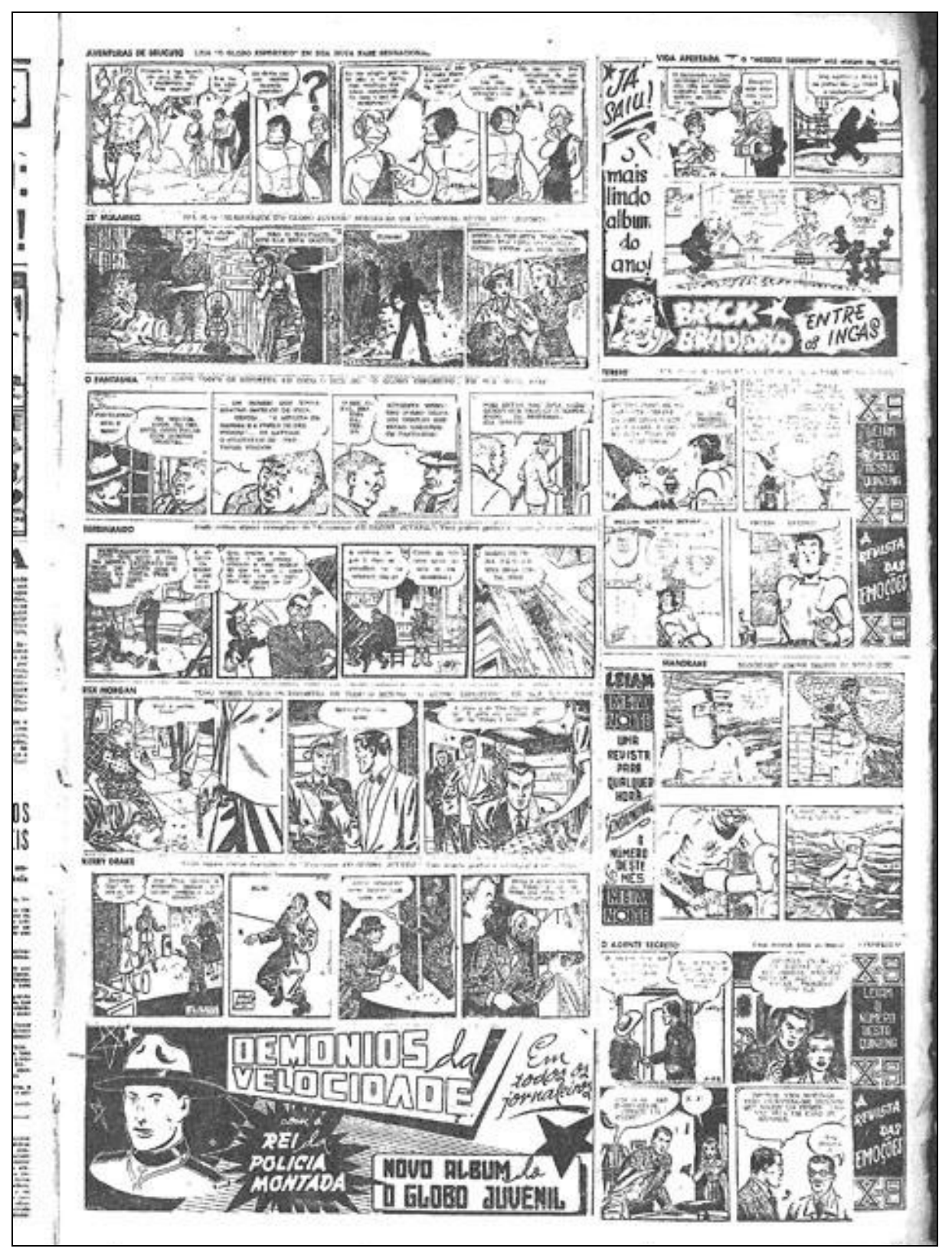

Figura 10: página do jornal $O$ Globo de 15/01/1951

Fonte: SILVA, F. L. C. M. O Quadro nos Quadrinhos. Rio de Janeiro: Multifoco, 2010, p. 75

O quadrinista e pesquisador Henrique Magalhães (2006), em uma obra dedicada exclusivamente às tiras cômicas, também não trata com detalhe e precisão de seus primórdios no Brasil. No capítulo inicial do livro, destaca o papel pioneiro de Angelo 
Agostini no que se refere às histórias em quadrinhos nacionais, e cita duas de suas criações: Nhô-Quim, considerada como a primeira delas no país, e Zé Caipora, personagem inovador por seus traços realistas. Curiosamente, no entanto, ao discorrer sobre a origem das tiras, aborda os Estados Unidos, depois menciona a Grã Bretanha, a França e a Argentina e nada diz sobre nosso país (2006, p. 12).

Uma consulta ao acervo digital da Folha de S. Paulo revelou que a partir de novembro de 1931, quando a publicação ainda se chamava Folha da Manhã, o jornal passou a publicar diariamente a tira Delícias da vida conjugal, uma nova tradução de Bringing up father, curiosamente o mesmo título com que a série foi batizada na Argentina. As leituras efetuadas apontam que nesse jornal, que posteriormente terá um papel importante para a produção local, o fato mais relevante no que se refere à história das tiras cômicas brasileiras se deu em 1959, quando Mauricio de Sousa estreou com seu personagem Bidu, inicialmente com periodicidade semanal e, a partir de 1960, diária.

Voltando ao Rio de Janeiro, Silva cita que o Jornal do Brasil passou a publicar tiras diárias em 1957, após passar por uma reforma radical em seu design gráfico, deixando de ser um jornal com muito texto e até anúncios na capa para uma publicação com fotos, cartuns e uma página exclusiva de tiras.

Essa lacuna de documentação de informações reflete um fato que diferencia substancialmente o percurso das tiras cômicas brasileiras das argentinas. Aqui, as histórias em quadrinhos se disseminaram através de revistas e suplementos de jornais e estiveram sempre muito associadas ao público infantil. Além disso, o esquema de distribuição de tiras cômicas para publicação em jornais operado pelas agências internacionais, associado aos grandes monopólios jornalísticos no Brasil, foi avassalador para os autores locais. As páginas dos suplementos traziam praticamente só produções estrangeiras. Bibe-Luyten (1985, p. 68) afirma que, em nosso país, os editores de quadrinhos tiveram mais destaque do que muitos desenhistas. Em vários títulos da bibliografia pesquisada encontramos menção à iniciativa frustrada de nacionalizar a produção de quadrinhos no Brasil como forma de incentivar a produção local e possibilitar aos quadrinistas condições de trabalho dignas.

No campo dos quadrinhos e do humor gráfico brasileiro na década de 60 , merece destaque uma iniciativa levada a cabo no sul do país, a CETPA - Cooperativa Editora de Trabalhos de Porto Alegre - criada em 1961 e cuja curta vida - pouco mais de dois anos se deu em meio ao tumultuado contexto político nacional que antecedeu o golpe militar de 1964 e foi fortemente marcada pelas disputas ideológicas daquele momento. A 
CETPA foi uma concepção do desenhista carioca José Geraldo, dos jornalistas gaúchos João Maia Neto e Hamilton Chaves e contou com o apoio de Leonel Brizola, então governador do Rio Grande do Sul (GUAZZELLI FILHO, 2009, p.37). Tratava-se de uma cooperativa que funcionava como editora e distribuidora e atraiu desenhistas de todo o país. Seu "objetivo era publicar quadrinhos identificados com nossos costumes e nossa cultura" (idem). Um dos produtos distribuídos pela CETPA foram as tiras do personagem Zé Candango (Figura 11), criação do desenhista Renato Canini. O personagem era um cangaceiro que lutava contra os personagens estrangeiros que haviam dominado o mercado brasileiro e suas tiras chegaram a ser publicadas nos jornais Última Hora de Porto Alegre, e Jornal do Brasil do Rio de Janeiro (ibidem).

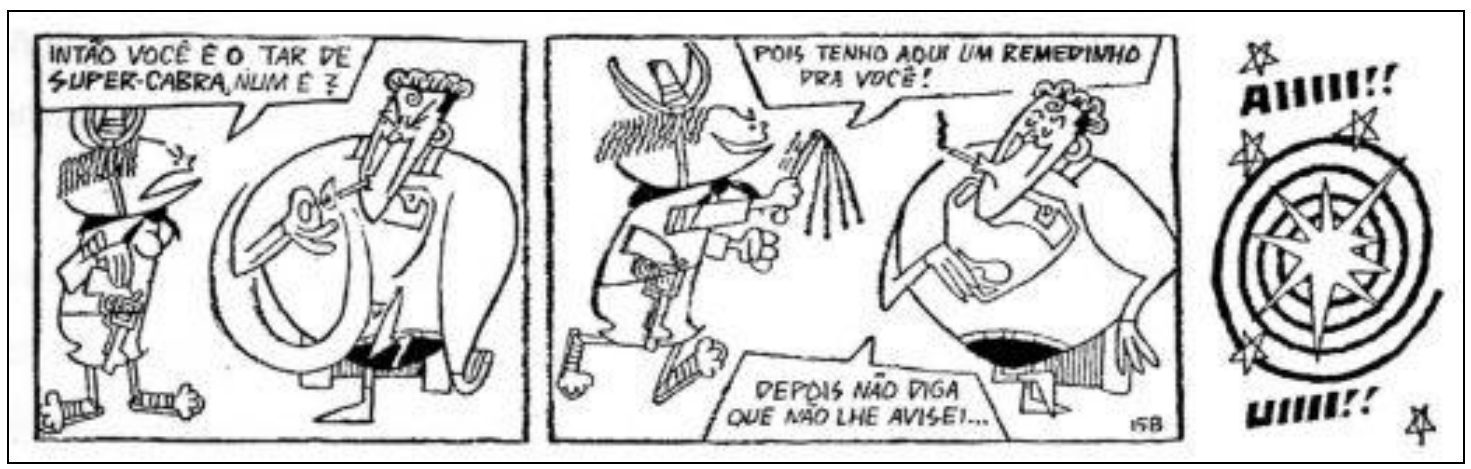

Figura 11: Zé Candango de Renato Canini

Fonte: http://blogdosquadrinhos.blog.uol.com.br/arch2009-04-01_2009-04-30.html

Precisamente do Rio Grande do Sul são duas outras produções que tiveram um papel importante durante os anos 70: as tiras do personagem Rango, de autoria de Edgar Vasques e As Cobras de Luis Fernando Veríssimo.

Estávamos sob a ditadura militar e Rango, cujo nome vem da gíria para comida, incomodará bastante os militares por tratar de um tema tabu e muito incômodo: a fome decorrente da miséria. Suas tiras foram publicadas diariamente entre 1972 e 1975 no jornal Folha da Manhã de Porto Alegre (GUAZZELLI FILHO, 2009, p. 41)

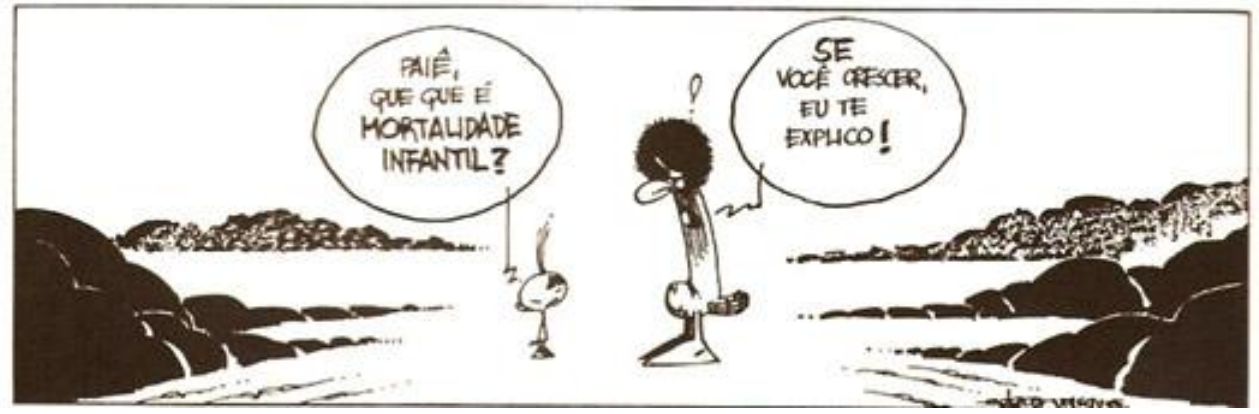

Figura 12: Rango de Edgar Vasques

Fonte: http://www.mundohq.com.br/site/detalhes.php?tipo=3\&id=53 
Durante os chamados anos de chumbo da ditadura, o humor foi uma das vias encontradas para se dizer o que não era permitido dizer explicitamente. Não que o humor gráfico tenha ficado isento da censura, porém as charges - por estarem ancoradas na política - eram mais visadas e com isso as tiras às vezes conseguiam driblar os censores. Assim, Luis Fernando Veríssimo embutia nas tiras cômicas protagonizadas pelas cobras, um forte discurso político. As cobras foram publicadas pelos diários Zero Hora, de Porto Alegre e Jornal do Brasil, do Rio de Janeiro e alcançaram grande sucesso com o público (Magalhães, 2006, p.50).

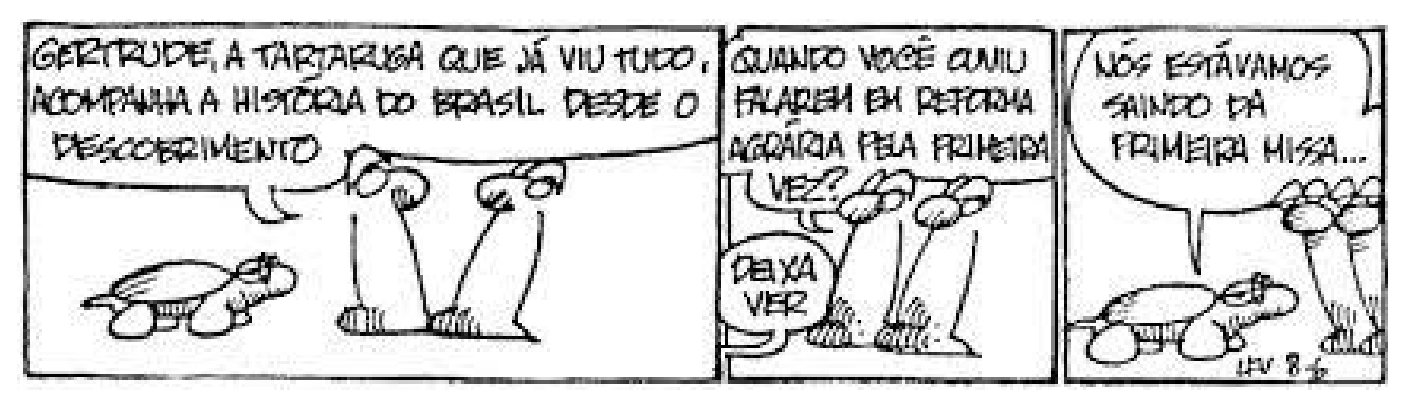

Figura 13: As cobras de Luis Fernando Veríssimo Fonte: http://grafar.blogspot.com.br/2008/06/as-cobras-luis-fernando-verissimo_09.html

Dessa época, merece também ser citada a tira $O$ Pato, também protagonizada por animais e criação de Ciça, nome profissional de Cecilia Whitaker Vicente de Azevedo Alves. Ciça tem destaque não só pelas características de sua produção, mas também por ser uma das pouquíssimas mulheres a atuar no campo de produção de quadrinhos no Brasil. Seu traço remete ao universo infantil e isso talvez a tenha protegido durante um tempo da tesoura dos censores da ditadura. Conforme explica Magalhães (2006), as histórias das tiras de $O$ Pato que inicialmente eram protagonizadas somente pelo animal que lhe dá título, passaram depois a contar também com formigas, galos, galinhas sabiás e até ovos, "criando personagens e papéis que representavam as relações sociais e o jogo de poder" (op. cit, p. 48). Entre os veículos de circulação diária nos quais suas tiras foram publicadas estão a Folha de S. Paulo, e o Jornal do Brasil do Rio de Janeiro. 

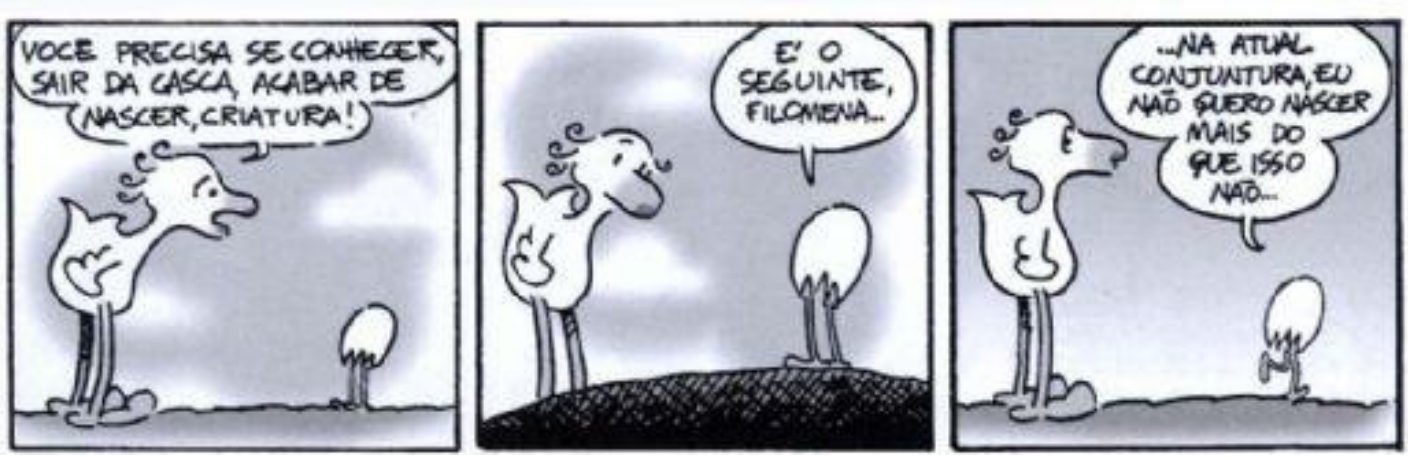

Figura 14: $O$ pato de Ciça

Fonte: http://www.lpm.com.br/livros/layout_capitulo2.asp?LivroID=535252

Retomando a relação dos autores de quadrinhos com as agências de distribuição internacionais, Magalhães (2006, pp. 26 a 29) destaca dois casos com finais diferentes. O primeiro deles é o de Henfil, que nos anos 1970, após um rigoroso processo, teve sua genial tira Os Fradinhos aprovada e assinou um contrato para sua distribuição nos Estados Unidos pela Universal Press Syndicate. Entretanto, o humor ácido e irreverente de Henfil não encontrou eco entre os estadunidenses, o público leitor dos jornais reagiu furiosamente e o contrato de publicação da série, que havia sido rebatizada de The Mad Monks (figura 15), foi cancelado pouco tempo depois. O outro caso é o do capixaba Milson Henriques, que também na década de 70, teve a sua tira Marly distribuída pela Intercontinental Press, uma agência sediada no Rio de Janeiro que representava uma série de tiras estrangeiras. Com isso, conseguiu que sua personagem - uma solteirona frustrada que passava o dia fofocando com as amigas - circulasse em jornais de todo o país.

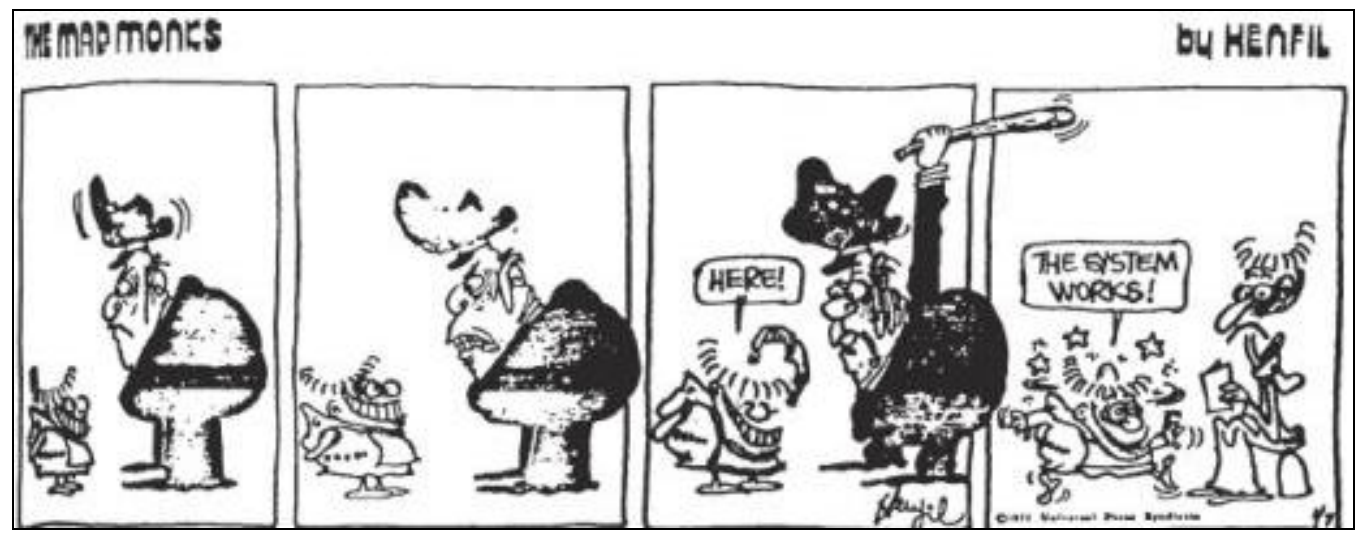

Figura 15: Mad Monks, versão em inglês de Os Fradinhos, de Henfil Fonte: http://blogdosquadrinhos2.blog.uol.com.br/noticia/ 
Antes de passar à Folha de S. Paulo, citaremos ainda Mauricio de Sousa e Ziraldo, duas grandes exceções no campo. Ambos conseguiram fugir do esquema das agências de distribuição criando seu próprio estúdio, com uma metodologia de trabalho em equipe, autodistribuindo suas produções e investindo também em licenciamento de imagem para os mais diversos produtos, no caso de Mauricio de Sousa, de cadernos a empanados de frango. No desenrolar de sua história, a produção de tiras cômicas para jornais, o nicho em que ele começou, talvez seja hoje a parte menos importante no império que criou.

Ziraldo, por sua vez, capitaneou uma iniciativa importante quando dirigiu a Funarte em meados da década de 80: criou a Agência Funarte de Quadrinhos Brasileiros em 1985, dirigida por Ricky Goodwin e Marco Antonio de Carvalho, que tinha como objetivo distribuir quadrinhos nacionais a jornais e revistas, concorrendo com as agências internacionais. Segundo Magalhães (2006, p. 35), o trabalho da Agência superou as expectativas tanto com os autores quanto com os jornais, e tinha um esquema de trabalho que se preocupava em não massificar a produção de somente meia dúzia de autores em detrimento de outros menos conhecidos. Para tanto, sempre incluíam no pacote para o jornal um autor do local em que estavam firmando o contrato de distribuição. A Funarte foi extinta em 1990, durante o governo Collor e com ela a Agência, mas a experiência adquirida serviu aos diretores para criar uma nova distribuidora: a Pacatatu.

\subsubsection{A página de quadrinhos da Folha de S. Paulo}

Em São Paulo, o principal jornal para a afirmação das tiras de produção local foi, e muito provavelmente ainda seja, a Folha de S. Paulo. Nesse processo, é inegável a importância dos autores Angeli, Glauco e Laerte, a chamada Geração Circo. Embora a editora pela qual publicavam e cujo sucesso alavancaram, a Circo Editorial, não tenha sobrevivido à grave crise econômica brasileira dos anos 90, suas produções - críticas, repletas de ironias, sarcasmo e humor negro - tiveram lugar cativo na página de quadrinhos da Ilustrada, o caderno de cultura da Folha, durante mais de uma década. Ramos (2012, p. 491) afirma que o trio "ajudou a dar a cara do quadrinho urbano que surgia em São Paulo na década de 1980, época em que o país passava pelo processo de redemocratização, após anos de regime autoritário". Ciente do reducionismo, posto que suas produções merecem muito mais do que aqui lhes podemos dar, destacamos o caráter transgressor das tiras. Em sua melhor época, as páginas da Ilustrada abrigaram personagens que tinham como características marcantes o uso de drogas, a compulsão 
sexual, o alcoolismo, conflitos edipianos e um variado leque de comportamentos e atitudes que hoje, na era do politicamente correto, seguramente seriam alvos de ataques. Dos três autores que destacamos por marcarem a virada dos quadrinhos nos anos 80/90, o único que segue publicando atualmente na Ilustrada é Laerte. A título de exemplo, reproduzimos uma tira de cada um deles nas figuras 16 a 18 .
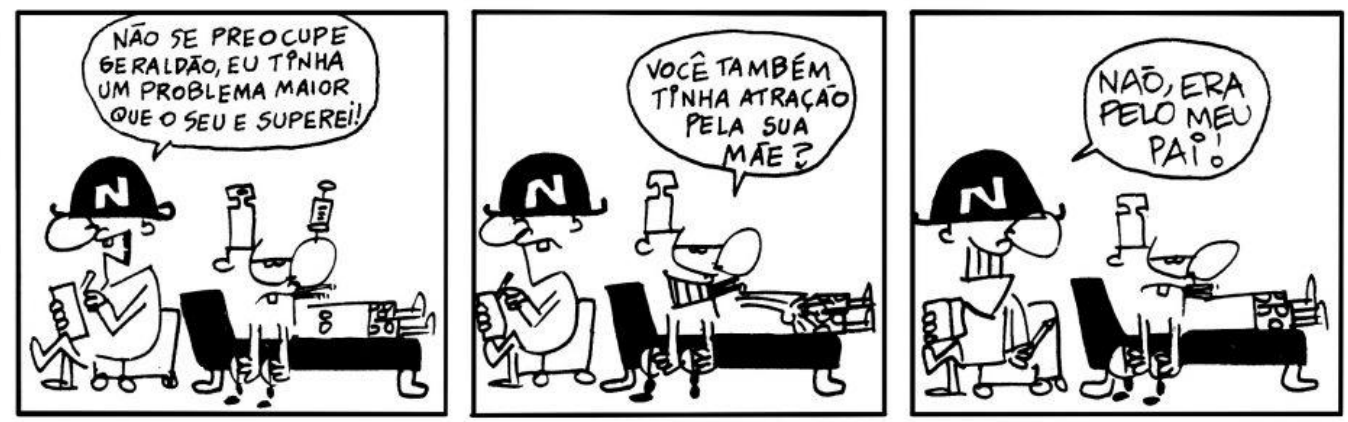

Figura 16: Geraldão, de Glauco Fonte: <http://entretenimento.uol.com.br/album/geraldao_livro_glauco_album.htm>. Acesso em 23/11/2013.
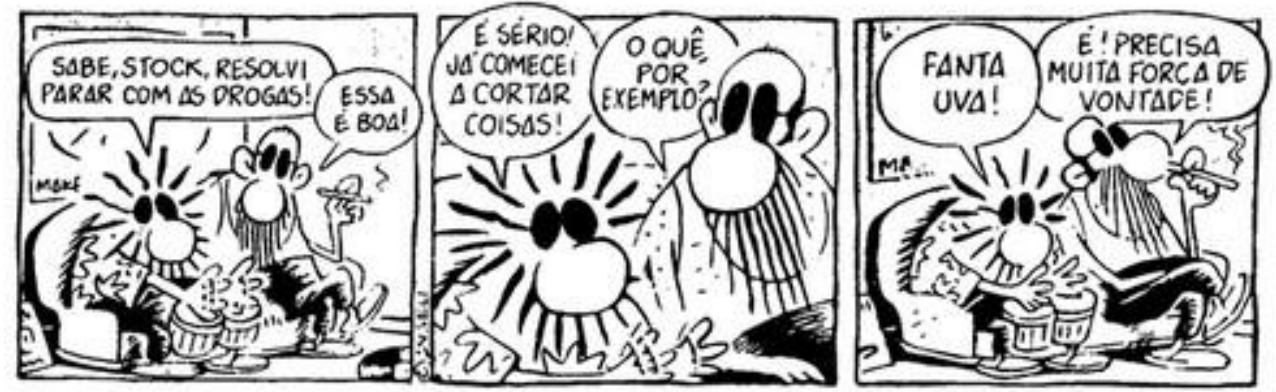

Figura 17: Wood e Stock, de Angeli

Fonte: < https://deposito-de-tirinhas.tumblr.com/post/28129441433/wood-stock-por >. Acesso em 23/11/2013.
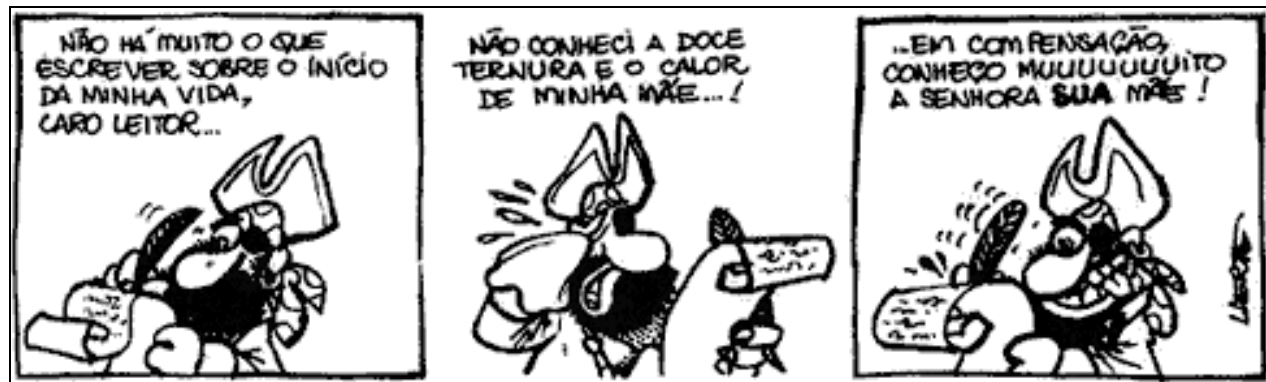

Figura 18: Piratas do Tietê, de Laerte

Fonte: 〈http://www2.uol.com.br/laerte/tiras/>. Acesso em 23/11/2013.

Não obstante o papel fundamental desempenhado pela seção Quadrinhos da Folha de S. Paulo como espaço para a publicação de tiras nacionais, é preciso destacar que ele 
passou a contar exclusivamente com produções de autores brasileiros somente em 28 de junho de 2016, quase quatro décadas depois do Clarín. Os últimos remanescentes estrangeiros foram as tiras Hagar, de autoria de Dik Browne, publicada na Folha desde 1973 e Garfield, cuja autoria pertence a Jim Davis e que ocupava a seção Quadrinhos desde 1983. Não encontramos no jornal nenhum comunicado oficial a respeito da interrupção e nem sobre o fato de a seção passar a ser, a partir daquele momento, totalmente nacional, o que nos leva a pensar que essa mudança possa não ser definitiva ${ }^{44}$.

Destacamos, além disso, uma iniciativa editorial relevante por parte do jornal, porém de curta duração. Entre 9 de dezembro de 2013 e 08 de junho de 2015, a Folha publicou às segundas-feiras a seção Quadrinhas, exclusivamente com produções de quadrinistas mulheres, como Pryscila Vieira e Alexandra Moraes, que figuram como autoras de produções que serão analisadas no capítulo 5 .

A seção foi interrompida, no entanto, e não encontramos no jornal explicações ou justificativas a respeito da interrupção. Como bem destacou Pryscila Vieira ${ }^{45}$, em uma declaração a respeito, tratava-se de uma conquista importante pois:

Historicamente o humor é feito por homens, para homens, sendo que muitas vezes a mulher é o objeto da piada. Por essa e por outras, considerava importante ter um espaço para um humor que tratasse do universo feminino para conquistar as leitoras e até incitar novas profissionais a correr o risco (...). Percebi que a "Quadrinhas" era um bom meio para isso. Foi uma boa iniciativa da 'Folha de S. Paulo', que infelizmente foi ceifada. Espero que os jornais superem a crise que assombra as publicações impressas para que possamos ter novamente um espaço.

Talvez o momento de dificuldade por que passam as publicações impressas, citado por Pryscila Vieira, seja a principal causa e sua raiz se encontra na expansão das tecnologias digitais que alteraram completamente a produção e o consumo de informações.

Atualmente, às segundas-feiras a Folha publica a seção Quadrão, em que uma única produção gráfica, a cargo de diferentes autores e autoras, ocupa a quase totalidade do espaço que é dedicado às tiras nos outros dias da semana. Como pudemos constatar, o

\footnotetext{
${ }^{44}$ A interrupção gerou queixas por parte dos leitores, que por sua vez motivaram uma coluna de Paula Cesarino Costa em 17/07/2017, como ocupante do cargo de ombudsman naquele momento. http://www1.folha.uol.com.br/colunas/paula-cesarino-costa-ombudsman/2016/07/1792380-sobre-o-direitoa-satira-e-limites.shtml

45 Declaração disponível em http://blogdosquadrinhos.blog.uol.com.br/arch2015-07-01_2015-07-31.html. Acesso em 13/05/2017.
} 
veículo tem se permitido experimentar em algumas iniciativas editorais que colaboram na movimentação do campo, lamentamos, entretanto, que algumas tenham sido tão efêmeras.

\subsection{Comparando os dois percursos}

Ao refazer, com apoio bibliográfico, o percurso histórico das tiras cômicas e sua relação com os jornais no século passado na Argentina e no Brasil até o final do século $\mathrm{XX}$, fica bastante evidente a diferença do impacto causado pelas produções estrangeiras fornecidas pelas agências de distribuição no amadurecimento e no papel assumido pelas tiras cômicas de produção local.

O fato de no Brasil a publicação regular em jornais de tiras cômicas produzidas por autores nacionais ser escassa e ter demorado mais que no país vizinho e, além disso, devido à circulação de quadrinhos ter se dado durante muito tempo por meio de suplementos e revistas, fez com que os quadrinhos ficassem associados, de modo geral, ao público infantil. Consequentemente, o papel eventualmente assumido pelas tiras cômicas de produção local, de por meio do humor expôr para o debate as questões de cunho mais particular, também se viu prejudicado.

Bibe-Luyten (1985, p. 61), ao comparar a produção de quadrinhos na Argentina e no Brasil, afirma que no país vizinho "na época de Perón e Evita, houve pura e simplesmente uma proibição de se editar quadrinhos estrangeiros", situação que, segundo ela, durou alguns anos. Não conseguimos dados que confirmassem a afirmação; entrevistando nativos, o que nos reportaram é que havia barreiras alfandegárias que encareciam as produções estrangeiras e protegiam o produto nacional, mas proibição efetivamente não houve.

Talvez o protecionismo possa ser uma das causas da alta qualidade dos quadrinhos argentinos, porém nos parece que a principal razão para essa disparidade está em outra das diferenças que marcam a história dois países. Em Fanjul (2017), encontramos algumas reflexões para ajudar nossa interpretação. $O$ autor aponta que apesar de Argentina e Brasil terem um passado colonial comum, marcado também por disputas entre elites sócio-econômicas que terminaram por conformar sociedades em que a desigualdade parece delas fazer parte de forma inexorável, quando examinamos mais detidamente algumas particularidades veremos que na comparação o cenário no caso do Brasil é pior. 
No que se refere especificamente à escolarização, o aspecto que mais impactará no consumo de jornais e revistas, Fausto e Devoto (2004, p.360) em obra comparativa sobre a história do Brasil e da Argentina, apontam que:

No Brasil, apesar dos significativos avanços no campo da educação, com o analfabetismo entre os maiores de quinze anos caindo de $50 \%$ para $40 \%$ entre 1950 e 1960 , este continuava muito acima do verificado na Argentina, onde baixou de $12 \%$ para $9 \%$ no mesmo período.

Como se pode ver, a diferença naquele momento era brutal. Atualmente é um pouco menor, mas ainda considerável. Segundo dados do site TheGlobalEconomy.com, em 2013 a Argentina contava com 97,97\% de sua população alfabetizada e no Brasil essa taxa era $91,48 \%$. Além do que representa esse dado para a diminuição da desigualdade social e todas suas consequências, o fato de em meados do século XX a Argentina ter já taxas de analfabetismo que no Brasil só serão alcançadas uma década depois de entrado o século XXI tem reflexos consideráveis na leitura - e consumo - de jornais e revistas e, por conseguinte, na conformação do campo que delimitamos para nosso trabalho.

Os argentinos encontraram nas páginas de seus jornais diários um humor inteligente, que dialogava com seu modo de ser, com suas idiossincrasias, às vezes inclusive debochando delas, e que estabeleceu com as tiras cômicas uma relação que possivelmente alimentou e fez crescer as produções locais e, consequentemente, gerações de novos quadrinistas nos anos 70. Fenômeno que talvez esteja acontecendo atualmente no Brasil onde observamos uma crescente geração de novos quadrinistas, cuja principal plataforma para publicação é a Internet (cf. RAMOS, 2012).

Por outro lado, no cenário atual também não podemos deixar de sinalizar a grave crise por que passam os jornais diários, em nível internacional, justamente em virtude da massificação do acesso às mídias digitais. No Brasil, muitos veículos fecharam ou passaram a existir somente no meio digital. Nesse processo, muitos quadrinistas também perderam espaço para publicar. Estamos certamente em um momento de grandes mudanças no campo do humor gráfico e quadrinhos.

Para finalizar, é preciso também refletir que justamente pelas características que marcam a implantação do gênero em cada um dos veículos, os quadrinistas que nelas publicaram estavam/estão investidos de alguns valores, enunciam de lugares sociais diferentes. Ser autor da página do Clarín representa fazer parte de um grupo que historicamente marcou o campo por produções com determinadas características, personagens muito populares, temática vinculadas aos acontecimentos que impactavam o 
cotidiano. Por outro lado, ser autor da página da Folha de S. Paulo implica inserir-se em uma história em que as tiras cômicas têm características mais ligadas a um humor transgressivo, tanto com relação aos temas, como a seus efeitos e inclusive ao próprio traço dos desenhistas. Como vemos, não obstante enunciarem a partir do mesmo gênero, quadrinistas argentinos e brasileiros se inserem em quadros cênicos que apresentam muitas diferenças. Embora guardem muitas semelhanças em suas dimensões formais, na dimensão da inserção desse gênero discursivo na espacialidade social desses dois países há muitas diferenças. 


\section{CAPÍtUlO 5 - As Copas de 1994 e de 2014 nas páginas do Clarín e da Folha de S.Paulo}

\section{Introdução}

Nosso objetivo específico nesta parte do trabalho é, seguindo o instrumental teórico-analítico exposto, investigar as produções selecionadas, entendidas como gêneros discursivos, para

(i) verificar que efeitos de sentido são construídos sobre as derrotas e as vitórias das seleções argentina e brasileira nas edições da Copa de 1994 e 2014;

(ii) analisar os procedimentos utilizados para obter o humor e seus possíveis efeitos,

(iii) observar que relações seus discursos estabelecem com outros discursos da imprensa sobre o futebol ou a Copa nos respectivos países, (iv) verificar os posicionamentos que a respeito desses temas se revelam,

(v) analisar as semelhanças e diferenças com relação aos pontos anteriores nas produções de ambos os países.

Tendo em vista que as tiras cômicas constituem um gênero discursivo constituído por duas semioses, a verbal e a não-verbal, na análise enfocamos não só a materialidade linguística como também os elementos gráficos que compõem as produções ${ }^{46}$. Observamos a construção da cenografia nos termos de Maingueneau (2008) e o funcionamento do humor conforme as categorias propostas por Charaudeau (2006). Também mobilizamos os conceitos de Ducrot (1988) sobre polifonia e outras noções de estudiosos do discurso conforme o que cada produção demandava.

\footnotetext{
46 Baseamo-nos nas descrições e reflexões de Ramos (2009, 2015b) e Palacios (2013) a respeito da linguagem multimodal dos quadrinhos e do humor gráfico. Sem ânimo de propor uma gramática dos recursos não verbais, os autores destacam a inseparabilidade das duas semioses no processo de construção do sentido em gêneros do campo que analisamos.
} 
O capítulo está organizado basicamente em dois subcapítulos, Copa de 1994 e Copa de 2014, tomando cada uma das edições da Copa a modo de um estudo de caso $^{47}$ e apresentando primeiramente dados relativos aos aspectos gerais de cada edição.

Cada subcapítulo está dividido por sua vez em duas partes, nas quais enfocamos cada um dos países individualmente. Na Copa de 1994 começamos com a Argentina, e na de 2014, com o Brasil. Descrevemos minimamente o contexto histórico de cada país naquele momento, apresentando os dados que nos parecem mais relevantes, e discorremos sobre o desempenho das respectivas seleções no campeonato. Nesse percurso, nos valemos tanto do discurso da imprensa esportiva sobre os acontecimentos e os períodos, como também de reflexões teóricas das diferentes áreas das ciências humanas que se debruçaram sobre o futebol como um objeto de estudo. Também incluímos fotos e produções gráficas que não são parte do corpus de análise, mas que contribuem para os objetivos desta parte do trabalho.

Após a introdução descrita, apresentamos a análise das tiras que fazem parte do conjunto em questão (país e período enfocado na respectiva edição da Copa). Como as condições em que se deu a Copa no Brasil foram muito significativas do ponto de vista político e social, a descrição do contexto da Copa de 2014 é mais minuciosa e constitui um subitem no qual foram incluídas como objeto de análise algumas tiras que tematizam esse contexto.

Ao longo do capítulo, mostramos conclusões parciais que retomam os principais aspectos apontados em cada subitem. Depois de apresentados os dois casos, finalizamos o capítulo discutindo nossas conclusões comparativamente.

\footnotetext{
${ }^{47}$ Estamos usando o termo lato sensu, sem que isso represente procedimentos metodológicos seguidos estritamente. Entendemos que podemos nomear assim nossa pesquisa e análise na medida em que nosso trabalho não tem pretensão quantitativa e porque tratamos de explorar e descrever o mais amplamente possível as diferentes dimensões dos eventos e situações que abordamos. Para tanto, enfocamos não só a participação argentina e brasileira nas Copas estudadas, como também perseguimos na dimensão sóciohistórica a origem de dados que encontramos na materialidade discursiva das tiras analisadas.
} 


\section{O caso da Copa de $1994^{48}$}

\subsection{Aspectos gerais}

Os jogos da $15^{a}$ edição do campeonato se realizaram nos Estados Unidos entre 17 de junho e 17 de julho. O país ganhara a disputa pelo direito de sediar a Copa competindo com Brasil e Marrocos. O anúncio de que fora o vencedor se deu seis anos antes, em um 04 de julho, data em que os estadunidenses celebram a independência do país, um dado que antecipava, nada discretamente, o resultado final. Por trás da escolha de um país sem tradição no futebol, havia a estratégia de expandir o esporte e tudo o que gera o futebol como negócio (FARIAS, 2014, p. 80).

Tanto o Brasil como a Argentina se classificaram para os jogos nos Estados Unidos com dificuldade. A Argentina conquistou a vaga na repescagem enfrentando a Austrália; quanto ao Brasil, classificou-se somente no último jogo.

\subsection{A Argentina na Copa de 1994}

No âmbito político-econômico, a Argentina vivia os últimos anos do primeiro mandato de Carlos Saúl Menem e sob a égide das medidas econômicas neoliberais capitaneadas por Domingo Cavallo, seu ministro da economia, que promoveu a privatização de todos os serviços de utilidade pública e conseguiu um afluxo massivo de capital estrangeiro. A hiperinflação fora superada, mas a um custo que depois se revelaria altíssimo na grave crise de 2001-2002 ${ }^{49}$. Nesse ano, também estava em curso a reforma da constituição do país, que entre outras modificações, permitiria a reeleição de Menem em 1995.

\footnotetext{
${ }^{48}$ Detalhes das narrativas sobre as Copas como datas de partidas e resultados foram encontrados no site da Fifa (https://www.fifa.com/), nas páginas dos próprios jornais com os quais trabalhamos e no site https://copadomundo.uol.com.br/paises-participantes/brasil/jogos/. Quando nos basearmos em opiniões e comentários que tenham autoria, estas estarão identificadas. É preciso mencionar que a memória da pesquisadora também norteou a reconstrução dos acontecimentos.

${ }^{49}$ Em 2001 e 2002, os argentinos viveram uma crise econômica e política que na verdade vinha se delineando desde 1998, no final do segundo mandato de Carlos Saúl Menem. Em $1^{\text {o }}$ de dezembro de 2001 o governo decretou o chamado corralito: os depósitos bancários foram suspensos e os argentinos não podiam sacar mais do que mil pesos por mês. Os saques e os protestos tomaram conta do país e instalou-se uma crise política que culminou em uma sucessão de renúncias que levou os argentinos a terem, em um espaço de dez dias, cinco presidentes e dois ministros da economia diferentes (Fonte: <http://www1.folha.uol.com.br/folha/dinheiro/ult91u93997.shtml>. Acesso em 11 de dezembro de 2017.)
} 
A seleção argentina, como já mencionamos, quase ficou fora da Copa. Classificada na repescagem, nos Estados Unidos teve destino muito diferente daquele da seleção do Brasil, sofrendo um revés que marcou profundamente sua história futebolística. Pela relevância do episódio e por sua intrínseca relação com o material que abordaremos, será necessário descrevê-lo com algum detalhe.

A seleção estreou contra a Grécia, ganhando de 4 a 0 . Durante o jogo, Maradona, que entre 1991 e 1992 passara 15 meses suspenso do futebol por envolvimento com cocaína, marcou um gol de canhota, um "chutaço". Um instante captado em sua comemoração se tornou emblemático nas narrativas sobre el diez: após marcar o gol, ele corre em direção à lateral do campo e grita para uma câmara, aproximando-se da lente com os olhos arregalados, no rosto a expressão era um misto de raiva e desabafo ${ }^{50}$.

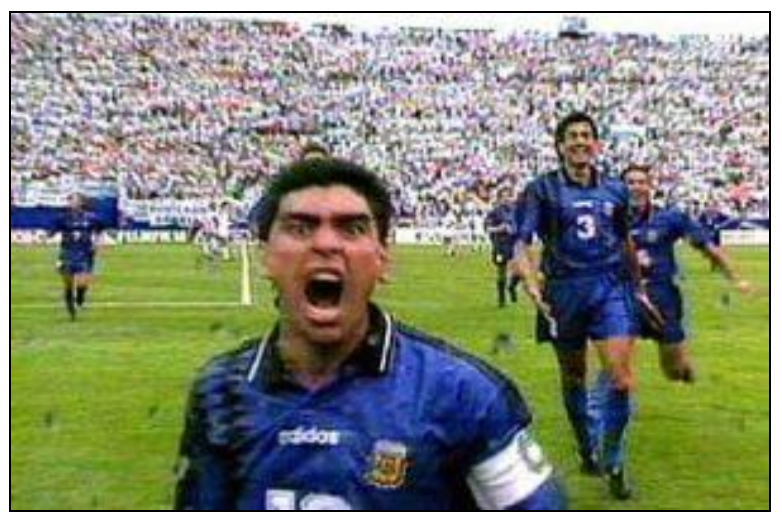

Figura 19 - Maradona - Argentina x Grécia - Copa de 1994 https://lemiaunoir.com/wp-content/uploads/2015/07/diego3.jpg

Ao vermos a cena em movimento, desde o gol até sua comemoração, essa imagem não é mais do que um instante, mas foi esse segundo captado pelas lentes dos fotógrafos o recorte que correu o mundo. De nosso ponto de vista, mais um ingrediente na construção de um ethos para Maradona por parte da mídia internacional em que, concomitantemente à genialidade com a bola, à esperteza e à autenticidade também se fazem presentes o descontrole e os excessos que marcaram sua vida extra-campo ${ }^{51}$.

Esse foi seu último gol em uma Copa do Mundo. Na partida seguinte, disputada em 25 de junho de 1994, a seleção argentina ganhou da Nigéria por 2 a 1 e Maradona foi sorteado para o exame do controle antidopping. Deixou o campo acompanhado de uma

\footnotetext{
${ }^{50}$ Archetti (1995) vê Maradona como um exemplo de pibe saído do potrero, duas ideias-chave dentro do passado mítico do futebol argentino. Em Alabarces (2005), por sua vez, encontramos uma análise bastante completa a respeito da construção do mito Maradona e sua posterior decadência.

${ }^{51}$ Por outro lado, parece haver por parte da imprensa argentina uma atitude mais positiva com relação a Maradona. A esse respeito, remetemos a Oliveira (2006) e Ribeiro et alii (2012), artigos que trazem pesquisas em que é possível comparar como Maradona é abordado pela imprensa argentina e pela brasileira.
} 
enfermeira, de mãos dadas com ela, numa cena que também se tornaria emblemática, pois ele não voltou a pisar os gramados como jogador de uma Copa do Mundo.

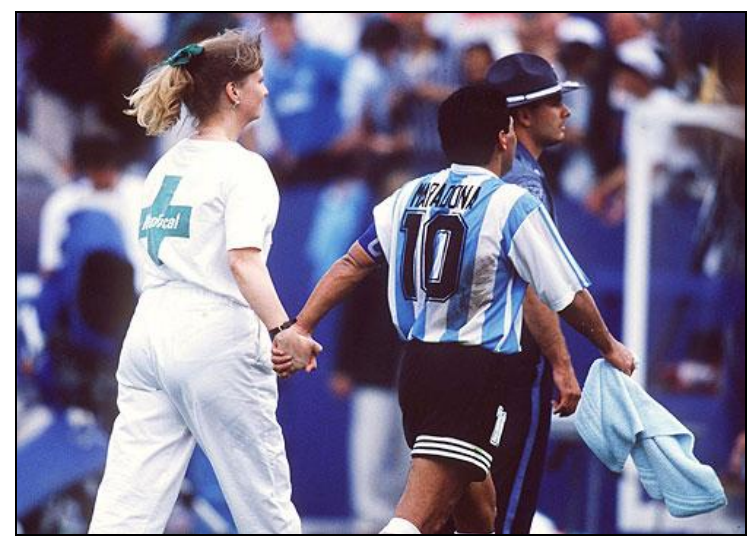

Figura 20 - Maradona - Controle antidopping - Copa de 1994 Fonte: http://www.canchachica.com/dopping-maradona/

O resultado de seu exame deu positivo para efedrina e pseudoefedrina, substâncias proibidas pela Fifa. O jornalista esportivo Waldemar Iglesias, em artigo publicado em 18/06/2014, assim comenta o desenrolar dos acontecimentos daquele momento (grifos nossos).

El 29 de junio se confirmó el resultado y, con él, todo el dolor del Babson College se trasladó a cada espacio argentino. Diego le había puesto cuatro palabras a su sensación. Y con su lucidez forjada sobre el barro de Fiorito creó una frase para siempre: "Me cortaron las piernas". Desde La Quiaca hasta los hielos de la Antártida, esa sensación de Maradona fue la sensación de todos.

Nos trechos destacados, podemos observar como se intensifica na narrativa o impacto que a confirmação do dopping teria causado aos torcedores argentinos, que passam a ser toda a população do país, primeiramente referida como cada espacio argentino e depois, homogeneizada em um bloco que compreende toda a extensão dele. Todos teriam sofrido juntamente com Maradona o sentimento que the provocou o resultado do exame: uma dor que ele sintetizou na frase me cortaron las piernas. Retenhamos desse fragmento os aspectos sublinhados, porque voltaremos a eles quando abordarmos as tiras publicadas.

Seguindo com a síntese sobre a participação da Argentina na Copa de 1994, o anúncio da confirmação do exame de Maradona e a sua consequente suspensão se deu horas antes da partida contra Bulgária e, como era de se esperar, o fato abalou profundamente o grupo de jogadores da albiceleste, que perdeu para os búlgaros por 2 a 0. Na partida subsequente, no dia 03/07/1994, a seleção argentina foi eliminada pela Romênia, com um resultado de 3 a 0 . 


\subsubsection{A seleção argentina, a Copa de 1994 e as tiras do Clarín}

No Clarín, os acontecimentos envolvendo Maradona e seu impacto para o desempenho da seleção são temas de tiras de dois autores que publicavam diariamente na página de humor do jornal naquela ocasião. As tiras Clemente, de autoria de Caloi, e De la crónica diaria, de autoria de Dobal dialogaram com os eventos que ocorriam nos Estados Unidos. Analisaremos quatro delas, publicadas entre os dias 02 e 04/07/1994, ou seja, os dias finais da participação da seleção argentina. Maradona já havia sido suspenso, a seleção já havia perdido para a Bulgária e no dia 03/07/1994 seria derrotada pela Romênia, jogo que eliminaria a Argentina da Copa. Começaremos com De la crónica diaria, de Dobal, reproduzida na figura 21 e publicada no dia 02/07/1994.

\subsubsection{De la crónica diária - Garrick}

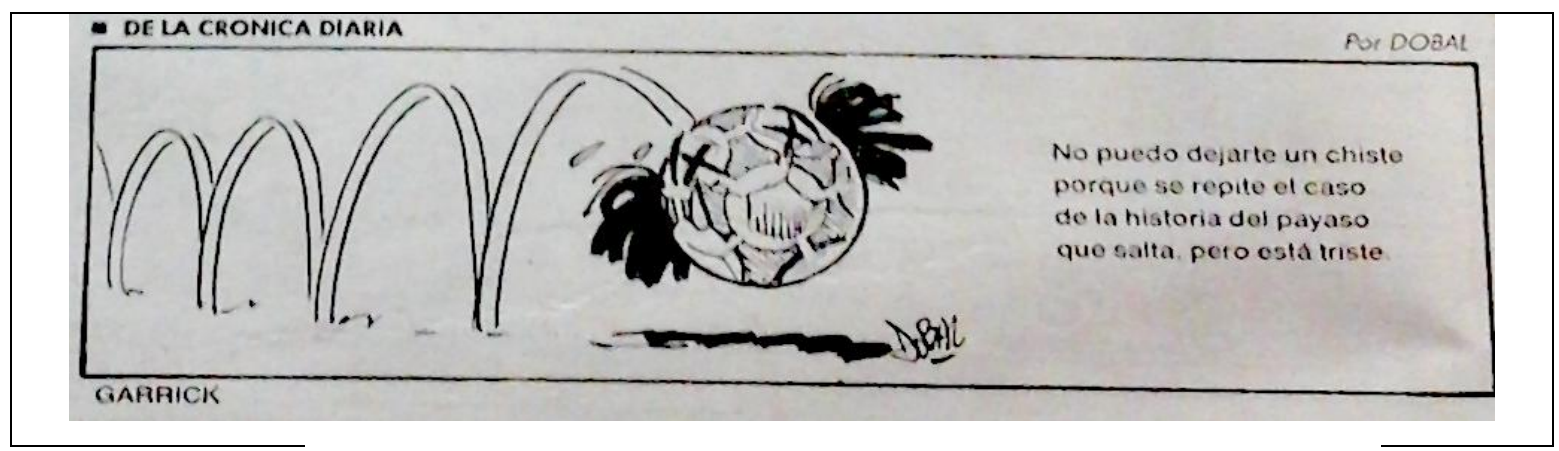

Figura 21 - La crónica diaria - Garrick - Fonte: Clarín de 2 de julho de 1994

Trata-se de uma tira que não tinha personagem fixo e, como o próprio nome indica, seus temas eram os acontecimentos do cotidiano ${ }^{52}$. Essa produção especificamente tem várias características peculiares, que fogem daquelas mais comumente associadas ao gênero tira cômica. Por isso, primeiramente nos parece importante fazer alguns esclarecimentos com respeito a essa questão. Ramos (2011, p. 83 a 107) aborda o tema de forma aprofundada e destaca a dificuldade de encaixar sob um rótulo a diversidade de formas que as tiras cômicas - e também as tiras em geral - assumem. Igualmente discute a complexidade de caracterizar esses possíveis rótulos, tendo em vista a variedade de recursos que as tiras utilizam para seus propósitos. De nossa parte, consideramos que essa produção de Dobal pode ser considerada uma tira cômica principalmente pelo seu

\footnotetext{
52 Para informações mais detalhadas, remetemos ao Apêndice, onde constam as biografias dos autores cujas tiras são analisadas neste capítulo 5 .
} 
formato, pelo veículo em que circulou, por sua inserção na temporalidade e também porque, embora não possamos assemelhá-la às piadas, entendemos que ela contém humor, no sentido postulado por Charaudeau (2006). Conforme já mencionado, lembramos que para esse autor, o humor consiste em uma estratégia discursiva que constrói uma visão desencaixada, transformada sobre os fatos do mundo, que seu emissor (locutor nas palavras do autor) busca compartilhar com seus interlocutores. De forma geral, o autor vê no humor sempre algo de lúdico, no sentido do jogo, mas não necessariamente associado ao riso. Como veremos, podemos encontrar nessa produção de Dobal as características elencadas com relação à visão construída sobre um fato, a saber, a suspensão de Maradona e a iminente derrocada da seleção do país.

Voltando à descrição da tira, no que se refere ao cenário e aos aspectos não verbais, temos uma produção em uma só vinheta, algo bastante comum no estilo de Dorbal. Nela vemos uma bola de futebol em primeiro plano, as linhas cinéticas que dela saem criam o efeito de movimento. A bola parece ter vindo saltando do fundo para a frente. Essa bola tem detalhes que constroem o rosto de um palhaço - dois tufos de cabelo laterais, alguns traços representando olhos e a boca, um risco em forma de $U$ invertido mostra tristeza. Há o desenho de duas gotas que tanto poderiam ser de suor como de lágrimas. Dobal já usara outras vezes a bola caracterizada como palhaço em tiras que se referiam ao evento da Copa do Mundo, como podemos constatar na que reproduzimos na

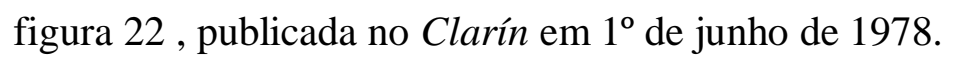

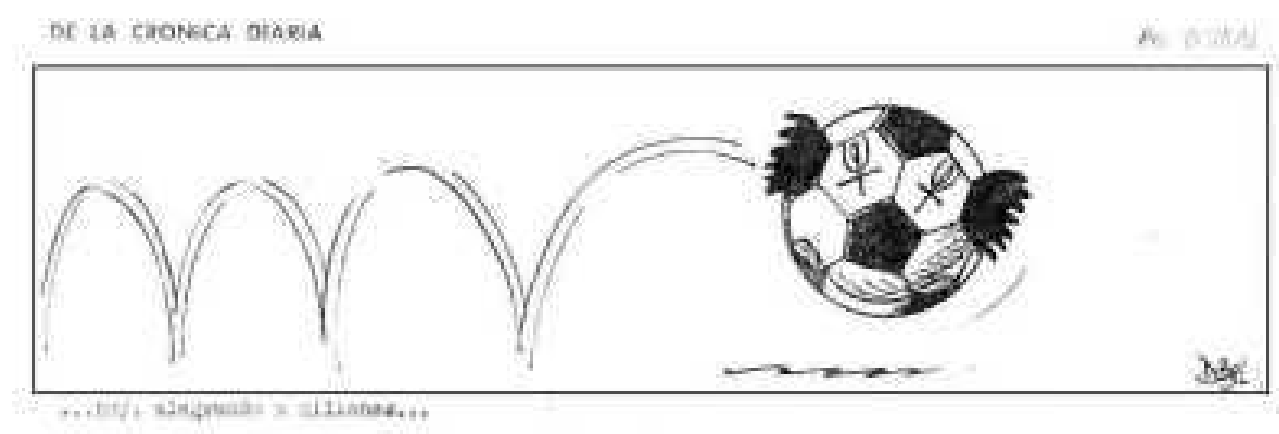

Figura 22 - La crónica diaria - Mundial de 1978 Fonte: http://www.temperleyweb.com.ar/biodobal.htm

A imagem, portanto, circunscreve para o leitor o tema sobre o qual versará a tira, a saber, a Copa, o que naquele momento significava falar dos acontecimentos envolvendo a suspensão de Maradona e as consequências para a seleção. 
Algumas das tiras que publicava Dobal têm outra característica como marca estilística, uma informação paratextual que contribui na construção do sentido. Na parte inferior delas, no exterior do espaço delimitado pela vinheta como cenário da tira, há uma inscrição. Diferentemente do título da tira (De la crónica diaria), que se encontra na parte superior esquerda e não mudou nunca ao longo do tempo em que Dobal publicou no Clarín, a inscrição na parte inferior era diferente a cada dia. No caso da tira reproduzida na figura 22, foi publicada no primeiro dia do Mundial de Futebol de 1978, a inscrição, ilegível na reprodução, é ...hoy alegrando a millones... ${ }^{53}$.

Na produção que estamos enfocando, reproduzida na figura 22, temos ao lado da bola-palhaço um texto, mas não em um balão-fala como seria o mais comum em uma tira. O texto é uma quadrinha, o primeiro verso rima com o último e o segundo com o terceiro. Nela, o locutor se escusa por não poder cumprir algo: no puedo dejarte un chiste, porque se repite el caso/ de la historia del payaso/que salta pero está triste. Está enunciada em primeira pessoa (no puedo) e convoca diretamente o alocutário por meio do pronome oblíquo te em dejarte. Ao usar a forma tú para dirigir-se ao alocutário, o locutor se coloca em uma posição de igualdade e proximidade na relação interlocutiva. Na identificação da instância enunciativa dentro do universo ficcional uma questão se coloca: qual é o referente desse yo que fala? A quem atribuir essa voz? À bola, como personagem, visto que ela parece ter vindo saltando e no enunciado o locutor se compara a um payaso que salta pero está triste? Embora nos pareça uma interpretação possível, há algo no primeiro verso que obnubila essa conclusão. Nele, o locutor afirma que não pode deixar uma piada, ou seja, pressupõe-se que era o que deveria fazer. E o responsável por "deixar" uma piada diariamente é quem assina a tira, seu autor. Assim, acreditamos que há uma sobreposição de possíveis interpretações para a identificação das vozes no enunciado da quadrinha. $\mathrm{O}$ locutor, o yo de no puedo tanto pode ser a própria bola, como personagem, como também o autor, não como sujeito físico - o L $\lambda$ nos termos de Ducrot (2001) - mas, sim, como o responsável pela produção verbo visual que é a tira, ou seja, aquele cuja assinatura figura na parte superior direita dela.

Se interpretarmos o locutor da quadrinha como sendo a bola-personagem, poderemos pensar que inclusive ela estaria triste pelo que aconteceu aos argentinos e a Maradona, o que mostraria o gigantismo do jogador que, uma vez afetado, afetaria o futebol como um todo. No entanto, a bola tem que continuar saltando, o jogo tem que

\footnotetext{
${ }^{53}$ Informação obtida no texto disponível em http://www.temperleyweb.com.ar/biodobal.htm, acesso em 20/05/2017.
} 
continuar. Por outro lado, se interpretarmos o locutor do enunciado na quadrinha como a voz do autor, nos parece que a tira não só repercute a tristeza pelos acontecimentos da Copa, como também toca o próprio ofício do quadrinista que assina tiras diariamente em um jornal: não importa o seu estado de ânimo é preciso produzir uma sequência de vinhetas e ela deve ter humor.

O subtítulo dessa tira é Garrick, um nome próprio. David Garrick foi um ator, comediante e dramaturgo inglês que viveu durante o século XVIII. A ele está dedicado o poema Reír llorando - também conhecido como Garrick $^{54}$ - do escritor mexicano Juan de Dios Peza ${ }^{55}$. Trata-se de um poema narrativo, em que um homem consulta um médico devido à tristeza sem fim que o acomete. Após várias sugestões refutadas, visto que todas já haviam sido provadas pelo triste homem, o médico lhe recomenda assistir a uma obra de Garrick, dizendo que com certeza isso o curará. Porém nem esse remédio terá sucesso porque então o homem se identifica e diz ser o próprio Garrick. Esses dados nos levam a crer que na cenografia que se desenrola nessa tira, o título funciona como o elemento que conduzirá à cena validada, que interpretamos como uma cena de teatro em que o intérprete se dirige ao público. O enunciado La historia del payaso que salta pero está triste presente nos dois últimos versos remete ao poema de Dios Peza e a seu protagonista, o cômico que faz os outros rirem não obstante seu pesar. Porém no caso da tira, tendo em vista o diálogo construído periodicamente por Dobal como autor com os temas do cotidiano, o motivo para a tristeza seriam os eventos que haviam sucedido nos Estados Unidos envolvendo Maradona e a seleção argentina. Além da informação recuperada no histórico do estilo da tira - o diálogo com os temas do cotidiano - , a outra pista que nos leva a essa interpretação é a bola, metonimicamente representando o futebol e o campeonato mundial.

Finalmente, olhando para os recursos mobilizados a partir das categorias propostas por Charaudeau (2006), entendemos que para lograr o humor, o autor se vale de

\footnotetext{
${ }^{54}$ Nossa busca demonstrou que o poema é bastante popular em países hispanofalantes, especialmente México e Argentina. O verso "Yo soy Garrick, cambiadme la receta" no qual se revela sua identidade, se converteu em uma espécie de frase feita, com a qual se demonstra que o tema é de amplo conhecimento daquele que a diz. Algo como em português, "ensinar o padre nosso ao vigário". Em um artigo assinado por Juan Pablo Carrivali e publicado no jornal El Diario da província de Paraná, Argentina, em 17/12/2016, encontram-se informações a respeito de Garrick, bem como o poema. O artigo está disponível em <http://www.eldiario.com.ar/edicion-impresa/ldquoiexclyo-soy-garrickhellipcambiadme-larecetardquo.htm>. Acesso em 23/05/2017.

${ }^{55}$ Historiador, jornalista, escritor e poeta mexicano, nasceu na Cidade do México em 1852 e ali faleceu em 1910. Fonte: <http://archivo.eluniversal.com.mx/notas/853302.html> . Acesso em 20/05/2017.
} 
procedimentos que classificamos dentro da incoerência insólita, pela mescla de referências de diferentes âmbitos sem relação aparente.

Pelo exposto, em nossa interpretação, a caracterização da bola como palhaço, o subtítulo e o enunciado em forma de quadrinha constroem uma cenografia enunciativa de uma cena teatral. Na referência ao poema de Dios Peza, vemos representações ligadas ao futebol como espetáculo, que pode tanto alegrar milhares como também entristecê-los; ao fim e ao cabo, trata-se também de lembrar que o futebol é um jogo, em que o acaso tem um papel importante. Nesse sentido, como efeito possível para o humor, entendido de forma ampla como já expusemos, vemos a conivência lúdica, aquela que busca uma fusão emocional com o destinatário do ato de humor, mostrando um outro olhar para as fatalidades. Ademais, ao mostrar-se afetado pelos acontecimentos envolvendo a seleção, localizamos no locutor traços de um ethos de solidariedade para com a seleção argentina e, por conseguinte, em consonância com a repercussão dos acontecimentos para os torcedores. Verifica-se, portanto, uma simbiose entre o locutor, a torcida e, por conseguinte, o construto que representa o país.

Acrescentamos que, pelas referências presentes no texto, também se evidencia um ethos de vasta cultura enciclopédica para o locutor, projetando igualmente essa característica para o alocutário. Cabe destacar que em nossa linha de raciocínio interpretativo sobre os efeitos de sentido nesta tira, não identificamos incompatibilidade entre ter vasta cultura e acompanhar os acontecimentos da Copa do Mundo de futebol, ou sofrer com eles, no caso. Dessa maneira, não vemos nos sentidos possíveis desse texto um olhar depreciativo para o futebol, como fenômeno de massa ou popular, visão que, como veremos, estará presente nas tiras brasileiras analisadas.

Passaremos agora à análise de três tiras de Clemente, publicadas consecutivamente entre 02 e 04/07/1994, na sequência dos acontecimentos que culminaram com a saída da Argentina do campeonato. As produções se encontram reproduzidas nas figuras 23,24 e 25 . 


\subsubsection{Clemente - Maradona}

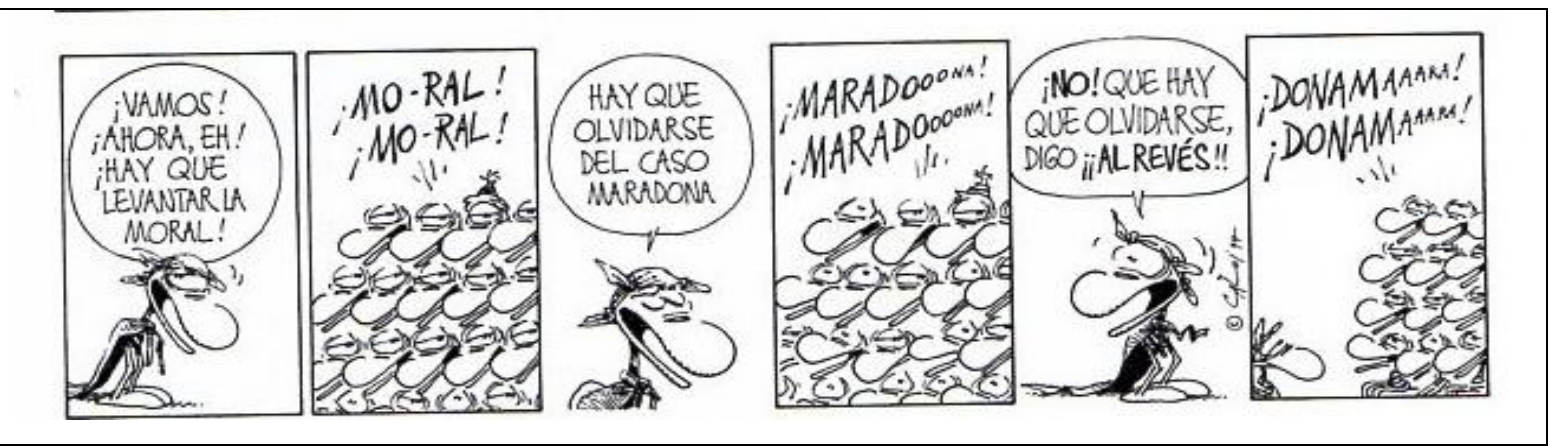

Figura 23: Clemente - Maradona - Fonte: Clarín em 02/07/1994

Embora tenhamos optado por analisar as tiras individualmente, na ordem cronológica de sua publicação, começaremos por um elemento que destacamos ser o mesmo nas três: a caracterização do personagem Clemente. A partir da realização do Mundial de Futebol na Argentina, em 1978, até 2010, a cada quatro anos as tiras de Clemente abordavam as Copas do Mundo. Às vezes um mês antes do campeonato, o evento já se convertia em objeto das produções de Caloi. A forma como o protagonista da tira passava a se vestir era uma das marcas adotadas pelo autor para identificar que o tema era a Copa. Observando a coletânea Clemente es Mundial (2014), constatamos que a caracterização foi adotada a partir de 1982, na Copa da Espanha. Caloi começa então a desenhar o personagem vestindo a bandeira da Argentina como capa e tendo na cabeça $e l$ pañuelo de cuatro nudos, uma espécie de chapéu feito de lenço de bolso, peça eventual da indumentária de trabalhadores braçais na Europa mediterrânea ${ }^{56}$. Na estátua que homenageia Clemente no Paseo de la Historieta ${ }^{57}$, o personagem está vestido dessa maneira. A bandeira é uma clara referência ao país, como Estado-nação, e o chapéu feito com os quatro nós marca a origem de Clemente como sendo dos estratos sociais ligados ao trabalho braçal. Sua fala também contém marcas dessa origem. Todos os elementos citados funcionam como estereótipos, como representações prévias que o leitor deverá acionar na construção do sentido. Nas três tiras que analisaremos, Clemente está caracterizado da forma já descrita, o tema das três, portanto, será a Copa do Mundo.

\footnotetext{
${ }^{56} \mathrm{Na}$ falta de algo mais adequado, tomavam o que tinham à mão para proteger-se do sol, o lenço de bolso, davam um nó em cada uma das pontas para formar uma concavidade e com isso protegiam a cabeça. Os imigrantes oriundos dos países que compõem essa região - especialmente Itália, Espanha e Portugal - que chegaram à Argentina e ao Brasil no século passado trouxeram consigo o hábito. Antes da obrigatoriedade do uso do capacete era comum ver trabalhadores da construção civil usando a peça.

${ }^{57}$ Ver capítulo 4.
} 
Passando a enfocar especificamente a figura 23, nela, além de Clemente, temos também a presença de um grupo, representado por vários rostos iguais ao do personagem que dá nome à tira, organizados de uma forma que poderia ser a arquibancada em um estádio. Clemente e os ocupantes dessa possível arquibancada só vão interagir na mesma cena na última vinheta, até a quinta estão sempre em vinhetas diferentes.

Muitas das tiras de Clemente iniciam com o personagem desenhado com o olhar para fora da tira, como se estivesse se dirigindo ao leitor virtual. Esse é também o caso dessa primeira que analisamos. O leitor virtual é convocado de forma explícita a participar da cena que se desenrola na tira. E o que "diz" Clemente como locutorpersonagem a esse leitor virtual em sua convocação? Passemos à materialidade linguística:

- o enunciado contido em seu balão-fala começa com ¡Vamos!: o verbo ir conjugado no Presente do Indicativo da primeira pessoa plural, entre sinais de exclamação, que funciona como um imperativo, nesse caso, com força ilocutiva de convocação. Uma convocação dirigida a um interlocutor coletivo [nosotros] em que o locutor-personagem Clemente se inclui.

- essa convocação é intensificada pelo advérbio ahora seguido da interjeição $e h$ (;Ahora, eh)!, Além do valor de imediatismo, parece-nos que aqui também cabe para esse advérbio o valor que destaca Matte Bon (2010, volume II, p. 122). Segundo esse autor, ahora é um operador temporal que pressupõe a existência de um antes ou um depois, que leva o interlocutor a entender imediatamente que se faz referência a outros momentos. No caso, entendemos que esses outros momentos são os eventos envolvendo Maradona e suas implicações para o desempenho da seleção argentina.

- temos por fím uma perífrase modal de obrigação [Hay que] com un valor general, que no se aplica a ningún sujeto en particular (idem, p. 63) ou seja, expressa con carácter impersonal la necesidad de que se haga algo en una situación dada. A impessoalidade sinalizada por Matte Bon refere-se tão somente à impossibilidade de personalizar o destinatário da obrigação, porém não tira a força ilocutória de obrigação da perífrase hay que. No caso em tela, vemos a obrigação como correspondendo à totalidade dos argentinos, a impessoalidade se dá porque não se especifica um sujeito, envolve a todos.

Como vemos, trata-se de um enunciado fortemente exortativo. Notemos que, embora os eventos com os quais a tira dialoga implicitamente envolvessem Maradona, a 
seleção, a equipe técnica, não são eles os destinatários desse enunciado. A cenografia criada faz com que o dito dentro do universo ficcional extrapole esses limites. Assim, entendemos que o nosotros a que se destina a exortação não se desdobra em Clemente + leitor virtual, mas, sim, em Clemente + leitor virtual + todos os argentinos assimilados simbolicamente com a seleção que disputava a Copa. Chama a atenção, no entanto, a contradição existente entre a imagem de Clemente, com o corpo e a cabeça posicionados de uma forma que reproduz uma atitude de abatimento, e o conteúdo de seu balão-fala. Fazendo um exercício de criatividade, se sua voz pudesse ser ouvida, poderíamos imaginá-lo reproduzindo o contido no balão de forma mecânica, com uma entonação sem muito vigor ou emoção.

$\mathrm{Na}$ vinheta seguinte a interação entre personagem e leitor virtual é interrompida e surge a imagem que identificamos como o grupo de torcedores na arquibancada. A cenografia passa a se desenrolar no plano interior da tira. Para representar que esse grupo estaria gritando em uníssono, o texto de sua fala aparece em um balão-zero ${ }^{58}$, em letras grandes, com as sílabas separadas e com vários apêndices marcando que se trata de uma produção coletiva, como se fosse uma claque, ou o coro do teatro grego. Esse locutorpersonagem coletivo faz eco à fala de Clemente e repete a última palavra: ;MO-RAL! ¡MO-RAL!.

$\mathrm{Na}$ terceira vinheta, Clemente já está desenhado de forma a representar uma atitude mais altiva que na primeira vinheta, com os olhos fechados, com o que interpretamos como um ar de autoridade, de reserva moral. Nesse sentido, o que dirá como locutor-personagem parece vir desse lugar de conhecimento e sabedoria. Temos novamente a perífrase hay que + infinitivo em um enunciado deôntico: Hay que olvidarse del caso Maradona. Unindo aspectos verbais e não-verbais, o enunciado ganha uma força de conselho imperioso, irrefutável, a única saída para uma situação, como uma sentença.

A partir da quarta vinheta opera-se na narrativa um sucedâneo de incongruências que começa a encaminhar ao desfecho humorístico. O coro repete o nome Maradona, porque fora a última palavra dita por Clemente, o que representa exatamente o contrário do que ele ordenara. Na quinta vinheta temos então um Clemente desenhado com cara de desespero. O personagem como locutor retoma seu primeiro enunciado, cita-se a si mesmo como enunciador (grifos nossos): ¡NO! iQue hay que olvidarse, digo! !AL

\footnotetext{
${ }^{58}$ Usamos a nomenclatura adotada por Ramos (2009, p. 39), conforme a qual balão-zero é quando não há contorno no balão-fala e apêndice corresponde à parte do balão que se projeta na direção do personagem que "fala".
} 
REVÉS! para dizer que o coro deveria fazer o contrário, não repetir o nome do jogador. O desfecho na sexta vinheta mostra que o coro da arquibancada interpreta o al revés como referindo-se ao nome Maradona e, por conseguinte, volta a repetir o nome do jogador, com as sílabas invertidas, ao contrário. Dizem DONA MARA, DONA MARA, uma forma de falar, ademais, muito relacionada ao $\operatorname{lunfardo}^{59}$ e que confere uma marca de coloquialidade à fala do personagem. A expressão no rosto de Clemente revela, em nosso ponto de vista, a constatação da impossibilidade de lutar contra a reação. Para além da inépcia evidenciada na reação dos personagens que compõem a possível arquibancada - a massa? -, se pensamos no papel que tem o coro no teatro grego, de personagem coletiva que provê informações importantes para o desenlace da tragédia, nos parece que também é possível pensar que a arquibancada expressa a impossibilidade de cumprir o que solicita Clemente como locutor, de seu lugar de autoridade experiente apelando ao racional e exortando a nação. Ou seja, era impossível esquecer el caso Maradona, ídolo da torcida e um ícone dentro da história do futebol argentino. Nesse sentido, interpretamos como um dos efeitos possíveis para o humor a conivência crítica, pela contra-argumentação que esse final da tira encerra a respeito do episódio Maradona, que entendemos, por sua vez, como o alvo do ato de humor.

Explorando a questão da cenografia, entendemos que estão em operação duas cenografias enunciativas. A primeira entre Clemente como locutor-personagem e o leitor virtual, ou seja, entre o plano interno e o externo à tira, simularia uma conversa cotidiana, em que uma pessoa trata de animar, encorajar uma outra diante de uma situação adversa. A segunda, já totalmente no plano interno à tira, desenvolve-se como uma situação em que um locutor individual - colocado ou colocando-se em uma posição de experiência e sabedoria - exorta um coletivo, que responde em uníssono. Entre as várias possibilidades que nos ocorrem - político a eleitores e correligionários, dirigente sindical a operários, apresentador a uma plateia -, acreditamos que seria plausível pensar na situação de um treinador falando a um time, que, por sua vez, dialoga fortemente com a de comandante a comandados. Nesse sentido, apoiando-nos em Franco-Júnior (2007, p. 235-237), lembramos a identificação entre um jogo de futebol e uma batalha. O autor, inclusive, vai mais longe e afirma que futebol é guerra simbólica. Segundo ele, vários indícios

\footnotetext{
${ }^{59}$ Nascido na periferia de Buenos Aires no final do século XIX, o lunfardo inicialmente era tido como linguajar usado pelos marginais da capital, mas acabou estendendo-se para outras regiões e atualmente várias palavras desse léxico fazem parte da fala de argentinos dos mais diferentes estratos sociais. A inversão silábica de determinadas palavras era uma das operações comuns no lunfardo e recebe o nome de falar em vesre (revés ao contrário) Fonte: http://www.todotango.com/musica/tema/7827/Tangointernacional/.
} 
comprovam essa identificação. No campo léxico, por exemplo, cita palavras e expressões oriundas do âmbito bélico usadas no universo do futebol: matar a bola, matar a jogada, artilheiro, capitão. Como sinônimos de partida temos duelo, confronto, embate, peleja. No que se refere ao próprio jogo, Franco-Júnior comenta que sua ambientação é claramente de sentido militar: "a arena onde se desenrola é cercada por escudos, bandeiras, hinos e 'gritos de guerra' das torcidas". E sobre a figura do treinador, afirma que é ele que como um general, mantém a tropa em boas condições de vencer, “(...) cuida do moral do grupo, que lhe infunde confiança cotidianamente e sobretudo às vésperas de luta (partida), em especial pouco antes (preleção) de se entrar no campo (de batalha)" (FRANCO-JÚNIOR, 2007, p. 239). Como vemos, trata-se de uma descrição que podemos aplicar com bastante propriedade à cenografia construída internamente na tira, com a ressalva de que em nosso caso, como estamos no âmbito do humor, a relação comandante e comandados acaba se revelando um arremedo. Observando esse mesmo aspecto a partir do proposto por Charaudeau (2006), entendemos que o procedimento discursivo para lograr o humor nessa tira se trata daquele classificado pelo autor como um jogo paródico. Nesse mesmo sentido, o outro procedimento que identificamos é linguístico, a polissemia do termo al revés. No plano ficcional da tira, Clemente o usa referido à enunciação dos personagens-locutores, estes, por sua vez, o interpretam como referido ao enunciado.

A segunda tira de Clemente que analisaremos (figura 24) foi publicada em 03/07/1994, no dia em que se daria o jogo contra a Romênia, decisivo para a permanência ou não da Argentina no campeonato.

\subsubsection{Clemente - En curda}

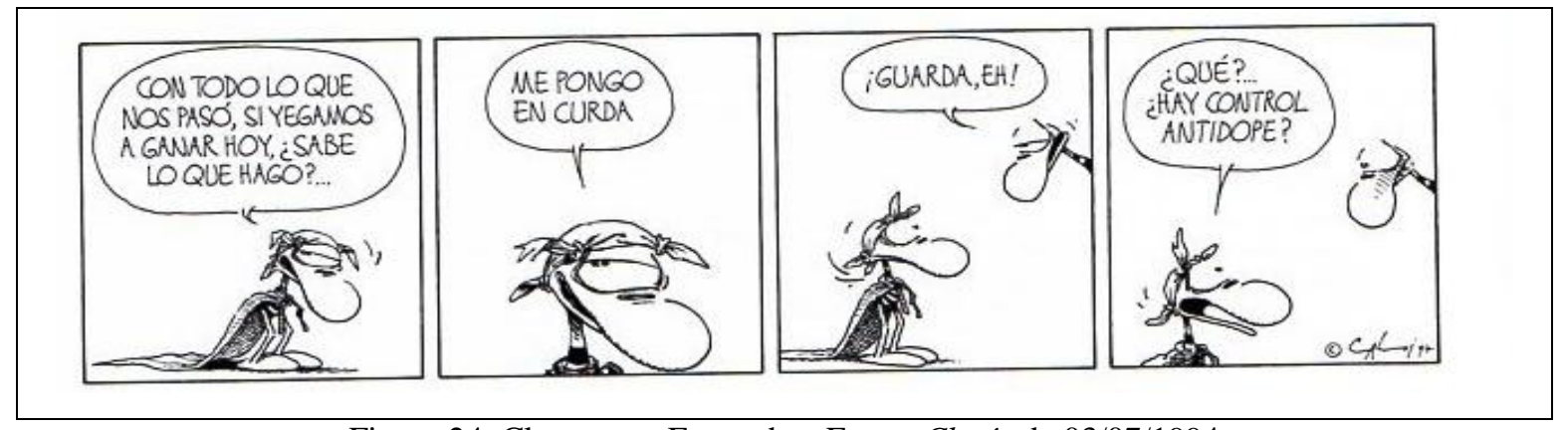

Figura 24: Clemente - En curda - Fonte: Clarín de 03/07/1994 
Tal como na tira anterior, vemos uma interação que se dá primeiramente com o leitor virtual, extrapolando para o exterior da tira, e outra, internamente, entre os personagens ficcionais. Embora seja um aspecto que também esteja presente nas outras tiras, nos parece que nessa produção específica os vários elementos que tentam apagar a barreira entre o ficcional e o não ficcional merecem mais atenção.

A narrativa se desenrola em quatro vinhetas e a cenografia construída, que se mantém até final, é a de uma conversa cotidiana. Na primeira, vemos um Clemente desenhado em atitude de desânimo, algo abatido, e com o olhar dirigido ao exterior da tira, para o leitor virtual. O enunciado contido em seu balão-fala inicia retomando os acontecimentos externos ao universo ficcional, o referente de todo lo que nos pasó não pode ser outra coisa senão os eventos envolvendo Maradona, sua suspensão e a subsequente derrota para a Bulgária. Segue-se uma condicional interrogativa ${ }^{60}$ cuja prótase é si yegamos ${ }^{61}$ a ganar hoy e a apódose é ¿sabe lo que hago? Trata-se de uma pergunta com fim retórico, um locutor real não esperaria como resposta o dado que falta, que interpela diretamente o leitor virtual (¿sabe [usted] lo que hago?). O uso do advérbio demonstrativo hoy ancora o enunciado no aqui e agora do possível momento da leitura da tira criando a ilusão de que o leitor interage realmente com Clemente e não com uma produção ficcional finalizada pelo menos algumas horas antes. Está também pressuposto que os jornais são lidos pela manhã, visto que a partida seria naquele dia, à tarde, o hoy da tira equivale ao dia 03/07/1994 até o horário do jogo. Na oração condicional, temos também a perífrase llegar a + infinitivo [yegamos a ganar] definida pelo Manual de la Nueva gramática de la lengua española (2010, p. 547) como uma perífrase escalar, que denota esforço e dificuldade para cumprir o expresso pelo verbo no infinitivo. Assim, é possível identificar no locutor-personagem uma atitude de pouca crença na condição que está sendo apresentada para que ele cumpra a promessa que só será enunciada no balãofala da segunda vinheta, qual seja, ponerse en curda, isto é, embebedar-se. Na cenografia criada mediante os elementos verbais e não verbais nessas duas vinhetas e em que se tenta apagar a fronteira entre a realidade ficcional e a não ficcional, mais um dado se coloca: a

\footnotetext{
${ }^{60}$ Agradecemos aos Profs. Drs. Adrián Fanjul, Benivaldo Araújo e Silvia Etel Gutiérrez Bottaro pelos esclarecimentos e indicações bibliográficas que ajudaram na análise desse enunciado em particular.

${ }^{61} \mathrm{O}$ uso de $y$ em lugar do $l l$ é característico da fala do personagem Clemente. Ao substituir a letra $l l$ pela $y$, Caloi reproduz e enfatiza o yeísmo, o desaparecimento da diferença fonológica na pronúncia das letras $l l \mathrm{e}$ $y$ em espanhol e que caracteriza a fala dos rio-platenses, argentinos e uruguaios. Essa é mais uma das muitas marcas que Caloi confere ao personagem para identificá-lo não só com a Argentina, como também com uma origem popular.
} 
seleção argentina ganhar naquele dia seria tão possível quanto um personagem ficcional ficar bêbado?

Chamamos ainda a atenção para o nosotros que está presente em nos (pasó) e yegamos. O personagem-locutor se inclui no enunciado como sujeito afetado pelos acontecimentos envolvendo a seleção argentina e também como o agente que disputará o jogo. Além de também assemelhar o ficcional e o não ficcional, entendemos que essa inclusão solidária responde ao que já mencionamos a respeito da identificação entre a seleção que representa o país e o próprio país como estado nacional. Desta sorte, o referente desse nosotros seria Clemente + leitor virtual + os outros argentinos, as três instâncias - inclusive a ficcional - poderiam ser englobadas sob a ideia do Estado-nação Argentina.

A partir da terceira vinheta, a interação encenada entre Clemente e o leitor virtual é interrompida porque outro personagem entra em cena e dirige a palavra ao primeiro. A interação que tem lugar no plano interno à tira culmina num ato de humor que lança mão de um procedimento disursivo que identificamos como incoerência insólita nos termos de Charaudeau (2006). Nesse caso, Clemente, como locutor-personagem, aborda na chave do humor um tema polêmico e o ressignifica. Assim, é trazida para o interior da cena justamente a causa dos problemas que afetavam a seleção argentina, ou seja, o controle antidopping que na fala de Clemente se converte em antidope. Porém nesse caso, em lugar de uma consequência negativa, causará graça. É possível que este termo contenha também um caso de resve, a inversão silábica típica do lunfardo, pois pedo, coloquialmente, é sinônimo de bebedeira. O controle antidope poderia ser então um controle antipedo, anti-bebedeira ${ }^{62}$.

Como efeito possível do ato de humor sobre o destinatário, vemos como mais preponderante a conivência lúdica, o leitor é convidado a compartilhar uma visão fantasiosa, e bem-humorada, sobre uma vicissitude.

Antes de concluir a análise dessa tira, há um aspecto que gostaríamos de destacar, embora não se relacione exatamente com o que estamos abordando nesta seção. Trata-se de um traço relevante da tira Clemente como atualização de um gênero discursivo, entendido como um dispositivo de comunicação sócio-historicamente condicionado (cf. MAINGUENEAU, 2010), a saber, o uso da forma usted, que aparece nas tiras como

\footnotetext{
${ }^{62}$ Agradecemos ao Prof. Dr. Adrián Fanjul a observação que nos levou a identificar o possível caso de resve no termo antidope.
} 
$u_{\text {sté }}^{63}$ para marcar a pronúncia coloquial, utilizada pelos personagens nas tiras de Clemente. No paradigma das formas de tratamento em espanhol, se trata daquela que marca assimetria na relação entre os interlocutores, reflete cortesia, deferência, respeito por quem a usa em relação a quem se dirige (cf. CARRICABURO, 1997, p. 9). Atualmente, tanto na Argentina como em grande parte do mundo hispanofalante, em função do avanço das formas simétricas de solidariedade informal preferidas pelos falantes (idem, p. 10) esse uso do usted está em descenso ${ }^{64}$. Inclusive, em muitas das situações ficcionais reproduzidas nas tiras de Clemente, o esperado seria o uso de vos entre os interlocutores. No entanto, quando o personagem nasceu, em 1973 a forma de tratamento usted era a que poderíamos dizer não-marcada entre as pessoas que não fossem íntimas, que não estivessem circunscritas ao âmbito das relações familiares. E, embora Clemente como tira tenha sido publicada durante muito tempo em plena vigência do vos e do descenso do usted na Argentina, a forma coloquial usté adotada pelos personagens da tira permaneceu como uma marca do momento histórico em que a personagem veio à luz. Por sua longevidade, pela forma como transcendeu a ficção, parece-nos que seria um acontecimento a ser explicado o fato de Clemente, e os outros personagens da tira, passarem a usar vos ou tú.

Passemos agora à terceira tira desta série, publicada um dia após a eliminação da seleção argentina dos Mundiais de 1994 e que reproduzimos na figura 25.

\subsubsection{Clemente - Lagrimones}

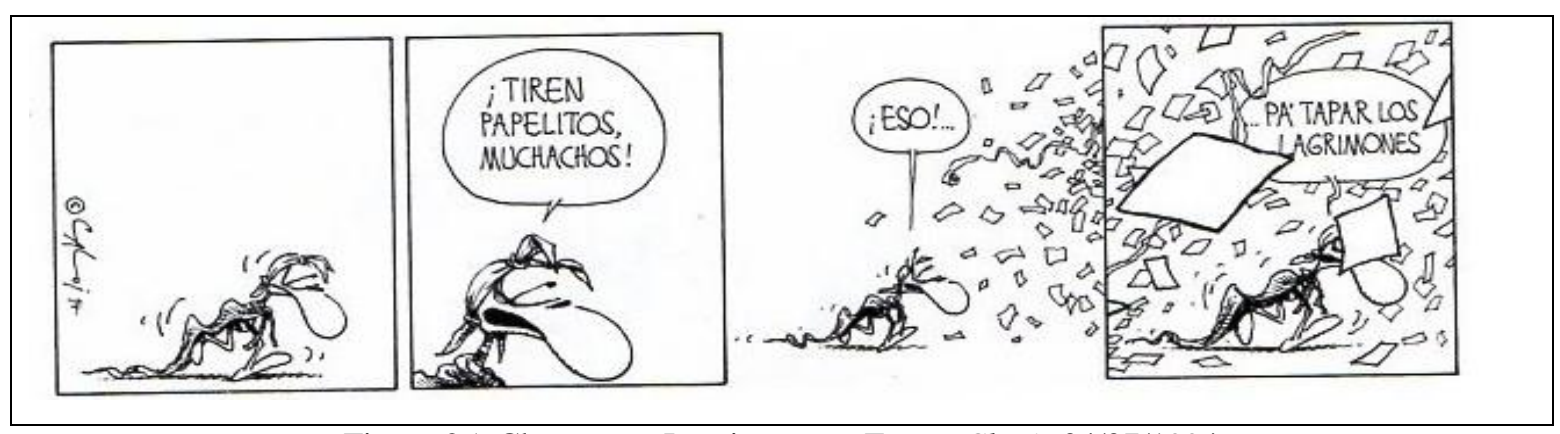

Figura 25: Clemente - Lagrimones - Fonte: Clarín 04/07/1994

Lembrando que as tiras analisadas comentavam os acontecimentos que tinham lugar nos Estados Unidos em 1994, se nas duas primeiras tiras, a imagem de Clemente era

\footnotetext{
${ }^{63}$ Ver também figura 35.

${ }^{64}$ Excluímos desse comentário os países em que o uso de usted não segue critérios de formalidade e distanciamento, como áreas da Colômbia e do Equador, por exemplo.
} 
de desânimo, podemos considerar que aqui é quase de aniquilamento. Na primeira vinheta o personagem parece surgir da lateral caminhando em silêncio, seu corpo e todos os elementos que compõem seu rosto estão arqueados, apontam para baixo, a capa, as pontas do lenço, tudo parece sucumbido a um enorme peso, é a própria expressão da derrota. $\mathrm{Na}$ segunda vinheta, em um plano em que só vemos seu rosto, em seu balão-fala lemos ¡Tiren papelitos, muchachos!, o mesmo enunciado que se tornou seu slogan no episódio conhecido como la guerra de los papelitos durante a Copa de 1978, o qual, por sua transcendência, passamos a descrever. Durante essa edição do campeonato, ocorrida, como sabemos, na Argentina e vencida também pelo país, Clemente - e, por conseguinte, Caloi - protagonizou um enfrentamento com as orientações que emanavam do governo, uma ditadura das mais ferozes, em um episódio que o converteria em símbolo do torcedor argentino da seleção. Conforme Ramos (2010, p.40), durante o Mundial os mandatários do país empreenderam uma campanha contra um hábito dos argentinos durante os jogos em estádios: jogar papeizinhos picados. O argumento era que isso sujava os estádios, sujeira que seria associada aos argentinos, e isso "no quedaba bien" considerando que se tratava de um evento internacional transmitido para o mundo inteiro. Um dos porta-vozes da campanha era o locutor José María Muñoz que em suas intervenções dizia "no hay que tirar papelitos". Caloi, em suas tiras diárias passou a colocar personagem Clemente questionando “¿cómo no vamos a tirar papelitos si los argentinos tiramos papelitos?”. Instaurou-se então a chamada "guerra de los papelitos": a população atendeu ao chamado de Clemente e nos estádios nunca houve tantos papeizinhos picados. Cada vez que aparecia a seleção argentina em campo, nos painéis eletrônicos dos estádios controlados pela Fifa e não pelos governantes - surgia a figura de Clemente pedindo “'Tiren papelitos muchachos!” e no jogo final contra a Holanda o gramado parecia estar pintado de branco.

Voltando à análise, entendemos, conforme Ducrot (1987), que nessa retomada não temos um locutor (L), mas, sim, um enunciador (E), cuja voz é na verdade a do próprio personagem Clemente, o de 1978, que irrompe na tira, porém não só em outro momento histórico, como também em um contexto completamente diferente, praticamente antípoda do anterior. Por sua vez, o enunciatário convocado, muchachos, extrapola o plano ficcional, pois não é o leitor-virtual, e sim os torcedores argentinos. O vocativo muchachos ademais, como forma nominal de tratamento confere aproximação e afetividade nessa convocação ao interlocutor. Esse enunciado instaura a mesma cenografia enunciativa da situação anterior - a cena validada -, a de 1978, em que o 
personagem, afiançado por um ethos que reunia simbolicamente as características do torcedor argentino, ocupou um lugar de líder da torcida nos estádios, defensor de suas manifestações e "falava" a partir dessa condição.

$\mathrm{Na}$ terceira vinheta, que não tem moldura, os muchachos parecem atender à solicitação de Clemente. Surgem papelitos à direita que vão aumentando em direção à vinheta seguinte. No balão-fala de Clemente-locutor lemos ¡Eso!, o pronome demonstrativo funciona como aprovação e estímulo. Sua imagem continua em direção à quarta vinheta e à chuva de papelitos, um deles termina por encobrir seu rosto. Temos então sua fala final, agora como personagem-locutor: "Pá tapar los lagrimones". Os papelitos não seriam para celebrar a glória, mas para cobrir a demonstração máxima da tristeza, o pranto, as lágrimas, ou mais que lágrimas, lagrimones, o sufixo aumentativo intensifica o impacto do resultado. Por outro lado, o enunciado traz também humor para a tira, embora seja um gracejo feito com ar triste. Identificamos dois procedimentos para a construção do humor nessa tira. Primeiramente, um jogo enunciativo paródico, porque se revive a situação da Copa de 1978, inclusive intertextualmente, mediante a citação do enunciado que tornou Clemente famoso naquele momento. Ao mesmo tempo, vemos também o procedimento que Charaudeau identifica como incoerência paradoxal, pois o emissor do ato de humor estabelece uma relação contraditória entre duas lógicas, a da vitória e a da derrota, ao invocar intertextualmente a situação de alegria da Copa de 1978 e o gesto que a marcava - tirar papelitos - com o objetivo contrário, ou seja, encobrir as lágrimas da tristeza pela derrota. Tal como na tira anterior, vemos a conivência lúdica como o efeito possível do humor nessa tira.

Entendendo que as três últimas produções têm a mesma fonte enunciativa, o locutor dos textos que as tiras repreentam, interpretamos que nas três é possível identificar no ethos construído discursivamente para esse locutor traços que remetem a uma atitude de igualdade e solidariedade na relação com o interlocutor, ou mais precisamente, uma identificação do locutor com o torcedor argentino. Nossa conclusão baseia-se na presença do pronome nosotros em procedimentos de referência inclusivos, compreendendo o interlocutor identificado como um membro do Estado-nação Argentina, no simbolismo que representa a forma como o personagem Clemente é afetado pelos acontecimentos que envolvem a seleção do país na Copa de 1994 e nos efeitos possíveis para o humor nas tiras.

Há ainda um aspecto que gostaríamos de explorar que dialoga com o que apontamos. No plano ficcional, há tantos elementos que conferem verossimilhança à dor 
demonstrada pelo personagem que por alguns momentos o leitor pode justamente chegar a esquecer que se trata de uma ficção. Ademais, se pensamos que a tira está tematizando a eliminação do país em um campeonato, a narrativa, pelo exagero, adquire ares de melodrama. Gostaríamos de relembrar o fragmento do jornalista Waldemar Iglesias (2014) que citamos na seção 1.2 deste capítulo, no qual podemos também localizar o exagero e a intensificação dos sentimentos que caracterizam o melodrama. Nele, seu autor comentava o impacto da divulgação do resultado do exame antidopping de Maradona afirmando que cada espaço argentino, de La Quiaca até a Antártida, havia sentido a dor que o craque expressara.

Martín-Barbero (1991), em seu estudo que inaugura um novo enfoque sobre a relação entre o popular e o massivo no âmbito da cultura da América Latina, vê o melodrama como uma das principais características dos produtos da cultura popular $\operatorname{argentina}^{65}$, tais como o tango ${ }^{66}$ e o radioteatro. Sobre o melodrama, o autor afirma

Todo en el melodrama tiende al derroche. Desde una puesta en escena que exagera los contrastes visuales y sonoros a una estructura dramática y una actuación que exhiben descarada y efectistamente los sentimientos exigiendo en todo momento del público una respuesta en risas, en llantos, en sudores y estremecimientos (op. cit. p.131).

Martín-Barbero assinala ainda que na América Latina del cine al radioteatro y la telenovela una historia de los modos de narrar y de la puesta en escena de la cultura de masa es, en muy buena parte, una historia del melodrama (idem, p. 132). Embora não estejamos trabalhando exatamente com gêneros abordados pelo estudioso, entendemos que podemos encontrar essa característica na forma como o episódio da eliminação da Argentina da Copa de 1994 foi glosada em pelo menos duas das tiras que analisamos, esta última e a de Dorbal (figura 21).

\subsubsection{A modo de retomada}

Nesta parte do capítulo 5, apresentamos informações sobre o desempenho da seleção argentina na Copa de 1994 e dados sobre como os eventos foram narrados pela

\footnotetext{
${ }^{65} \mathrm{O}$ autor localiza essa característica não só nos produtos da cultura popular da Argentina, como também nos de outros países da América Latina. Em suas palavras: En forma de tango o de telenovela, de cine mexicano o de crónica roja el melodrama trabaja en estas tierras una veta profunda de nuestro imaginario colectivo, y no hay acceso a la memoria histórica ni proyección posible del futuro que no pase por el imaginario (op. cit. p.243)

${ }^{66}$ Remetemos à leitura do trabalho de Menezes (2012) desenvolvido no Programa de Pós-Graduação em Língua Espanhola e Literaturas Espanhola e Hispano-Americana, que aborda em profundidade o tema no âmbito de um trabalho comparativo entre o tango e o samba.
} 
imprensa. Além disso, analisamos quatro tiras publicadas na página de humor do jornal Clarín no período entre 02 e 04/07/1994, que compreende os momentos finais de participação da seleção argentina na Copa dos Estados Unidos. As tiras foram selecionadas porque tematizavam o desempenho da seleção, bem como a suspensão do jogador Maradona.

$\mathrm{Na}$ análise, foram considerados não só os elementos verbais como também os visuais, em uma perspectiva que entende as tiras cômicas como um texto multimodal em consonância com o apontado por Ramos (2011, 2015) e Palacios (2013). Enfocamos as cenografias instauradas e interpretamos seu papel na construção dos possíveis efeitos de sentido nas tiras. As quatro produções analisadas convocam explicitamente o leitor virtual, instaurando uma interação com a exterioridade não ficcional. Esse procedimento esmaece a fronteira entre o real e o ficcional e colabora para estabelecer proximidade com o leitor das tiras.

Especificamente nas tiras que tematizavam os acontecimentos referentes ao dopping de Maradona e à eliminação da Argentina (figuras 21 e 25) identificamos elementos exortativos e melodramáticos que dialogam com outros estudos a respeito de gêneros de cultura de massa no país.

Quanto às categorias propostas por Charaudeau (2006) para análise dos atos humorísticos, resumimos nos quadros seguintes os procedimentos encontrados na construção do humor nas tiras e seus efeitos possíveis, segundo nosso ponto de vista.

\begin{tabular}{|c|c|c|c|c|c|c|c|}
\hline \multirow[b]{2}{*}{ Produção } & \multicolumn{7}{|c|}{ Procedimentos } \\
\hline & 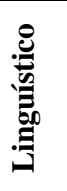 & 惫 & 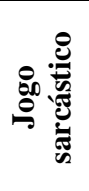 & 尊 & 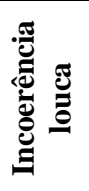 & 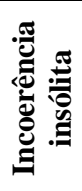 & 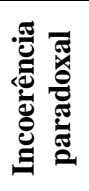 \\
\hline $\begin{array}{l}\text { La crónica diaria - Garrick } \\
\text { (figura } 21 \text { ) }\end{array}$ & & & & & & $\mathbf{x}$ & \\
\hline $\begin{array}{l}\text { Clemente - Maradona } \\
\text { (figura 23) }\end{array}$ & $\mathbf{x}$ & & & $\mathbf{x}$ & & & \\
\hline $\begin{array}{l}\text { Clemente - En curda } \\
\text { (figura 24) }\end{array}$ & & & & & & $\mathbf{x}$ & \\
\hline $\begin{array}{l}\text { Clemente - Lagrimones } \\
\text { (figura 25) }\end{array}$ & & & & $\mathbf{x}$ & & & $\mathbf{x}$ \\
\hline
\end{tabular}




\begin{tabular}{|l|l|l|l|l|}
\hline \multirow{2}{*}{ Produção } & \multicolumn{3}{c|}{ Efeitos possíveis } \\
\cline { 2 - 5 } & $\begin{array}{l}\text { Conivência } \\
\text { lúdica }\end{array}$ & $\begin{array}{l}\text { Conivência } \\
\text { crítica }\end{array}$ & $\begin{array}{l}\text { Conivência } \\
\text { cínica }\end{array}$ & $\begin{array}{l}\text { Conivência de } \\
\text { derrisão }\end{array}$ \\
\hline $\begin{array}{l}\text { La crónica diaria - Garrick } \\
\text { (figura 21) }\end{array}$ & $\mathbf{x}$ & & & \\
\hline $\begin{array}{l}\text { Clemente - Maradona } \\
\text { (figura 23) }\end{array}$ & & $\mathbf{x}$ & & \\
\hline $\begin{array}{l}\text { Clemente - En curda } \\
\text { (figura 24) }\end{array}$ & $\mathbf{x}$ & & & \\
\hline $\begin{array}{l}\text { Clemente - Lagrimones } \\
\text { (figura 25) }\end{array}$ & $\mathbf{x}$ & & & \\
\hline
\end{tabular}

Como podemos observar, entre os procedimentos e os efeitos possíveis identificados predominam aqueles que não trazem matizes de agressividade ou de depreciação, como poderiam ser o jogo sarcástico, a conivência cínica ou de derrisão. Esses dados dialogam com as características de solidariedade e simetria encontradas para os ethé dos locutores das tiras. Colocando em relação os dados encontrados com aquilo que tematizam, parece-nos que nas tiras analisadas aborda-se a repercussão dos resultados ruins da seleção argentina na Copa de 1994 de forma solidária, evidenciando-se seu impacto para a coletividade. Esses dados preliminares serão retomados na comparação final entre as diferentes situações analisadas.

\subsection{O Brasil na Copa de 1994}

A preparação para a Copa de 1994 se deu em meio a um cenário políticoeconômico marcado pela entrada em vigor do Plano Real, programa que conseguiu estabilizar a moeda e acabar com a hiperinflação. Itamar Franco era o presidente, assumira o cargo após a saída de Fernando Collor e estava em seu último ano de mandato. O sucesso do Plano Real pavimentou a eleição de Fernando Henrique Cardoso em outubro daquele mesmo ano, no primeiro turno, derrotando Luis Inácio Lula da Silva.

De acordo com Guterman (2014, p. 241), o sucesso do Plano Real trouxe para o país uma ânsia de reorganização, de busca pela excelência administrativa que chegou também ao futebol. Para alcançar esse objetivo foi convocado como técnico Carlos Alberto Parreira “cuja imagem estava ligada à tão procurada eficiência dos anos 1990" 
(idem). No entanto, a eficiência tardou um pouco a se manifestar, a seleção brasileira se classificou para a Copa com dificuldade, sua situação só se definiu favoravelmente no último jogo. Em 19 de setembro de 1993, Brasil e Uruguai se enfrentaram no Maracanã em mais uma espécie de reedição da final da Copa de 50, porém dessa vez o Brasil ganhou de 2 a 0. Os dois gols foram de Romário, convocado depois de Parreira finalmente ceder à intensa pressão que vinha de todos os lados - torcedores, jornalistas, cartolas - visto que o jogador fora seguidamente ignorado nas convocações durante a campanha para a vaga na Copa.

O "estilo" que Parreira, como técnico, imprimira à seleção era abertamente criticado pela imprensa esportiva e rejeitado pela maioria dos torcedores. Subjacente à crítica e à rejeição estava a tensão entre duas visões a respeito da maneira de jogar dos brasileiros que se refletirá também em tiras que analisamos. Parreira tinha fama de "retranqueiro", ou seja, de privilegiar a defesa em detrimento do ataque, tática que conferia à seleção um estilo de jogo que era o oposto do imaginário que cerca o futebol brasileiro. Este último, como destacam entre outros DaMatta (1994), Guedes (1998) e Helal (2006), seria identificável com o "futebol-arte" ou o "jogo bonito", sintagmas que trazem consigo um corolário de representações em que destacamos um determinado uso do corpo e a habilidade individual dos jogadores em driblar, fintar, iludir o adversário, dominar a bola menos com técnica e mais com talento individual, a arte. O comentário de Guterman (2014, p. 243) a respeito de como a seleção brasileira jogava sob o comando de Parreira é bastante representativo dessa tensão que mencionamos. Segundo ele,

\begin{abstract}
Durante a preparação para o Mundial, [Parreira] treinou exaustivamente jogadas ensaiadas de bola parada, porque, dizia, 45\% dos gols feitos na Copa de 1990 haviam saído em lances assim. Uma seleção como essa só podia ter como capitão o volante Dunga - ele mesmo, o símbolo da burocracia do futebol brasileiro europeizado. Ao lado dele jogou Mauro Silva, um autêntico tanque, cuja única função era proteger a defesa e destruir as jogadas adversárias. Desse modo, as credenciais competitivas da seleção passavam pela formação de um ferrolho no meio-campo. Não havia nada de "brasileiro" nisso, mas preocupações com "brasilidade", como se sabe, já vinham se tornado coisa do passado algo disso ainda respirava com os brilhantes Romário e Bebeto no ataque, mas era só. Àquela altura, o importante parecia ser somente ganhar o tetracampeonato.
\end{abstract}

Como podemos observar, na tensão entre as duas formas de jogar, é facilmente localizável o polo em que o autor se encontra. Embora coloque entre aspas os termos brasileiro e brasilidade, o que poderia indicar certo distanciamento dos valores aos quais os termos se associam, parece-nos que o gesto não passa de uma tentativa. Vê-se claramente um alinhamento do autor com a crítica à ruptura das características que marcariam o estilo de jogar futebol no Brasil. No texto, constrói-se uma oposição que 
coloca de um lado Dunga, símbolo da burocracia do futebol brasileiro europeizado e Mauro Silva, um autêntico tanque, e do outro, os brilhantes Romário e Bebeto no ataque. Nos primeiros, o autor identifica as credenciais competitivas da seleção, um ferrolho no meio-campo; nos segundos, um parco resto - que ainda respirava - da brasilidade no jeito de jogar, ou seja, a genialidade, a malícia, o talento que converte a jogada e o gol em um espetáculo e não o resultado de técnicas aplicadas. Nesse sentido, o encerramento do fragmento é bastante significativo. Ao dizer que o importante parecia ser somente ganhar o tetracampeonato (grifo nosso), temos como implícito que era preciso, além de ganhar, encantar, seduzir, mostrar o algo mais que envolvia as apresentações da seleção brasileira nas Copas do Mundo.

A maneira de ser de Parreira e o estilo de jogo nada "brasileiro" conferido por ele à seleção fizeram com que a delegação do país chegasse completamente desacreditada aos Estados Unidos. Na campanha contra o técnico repetia-se o bordão Fora Parreira!, que aparece na produção a seguir, publicada na parte dedicada às charges na Folha de $S$. Paulo de 30/06/1994, e que, embora não faça parte do nosso corpus, nos permitimos reproduzir e comentar, pelo que revela a respeito dos ânimos que a participação da seleção na Copa de 1994 despertavam naquele momento.

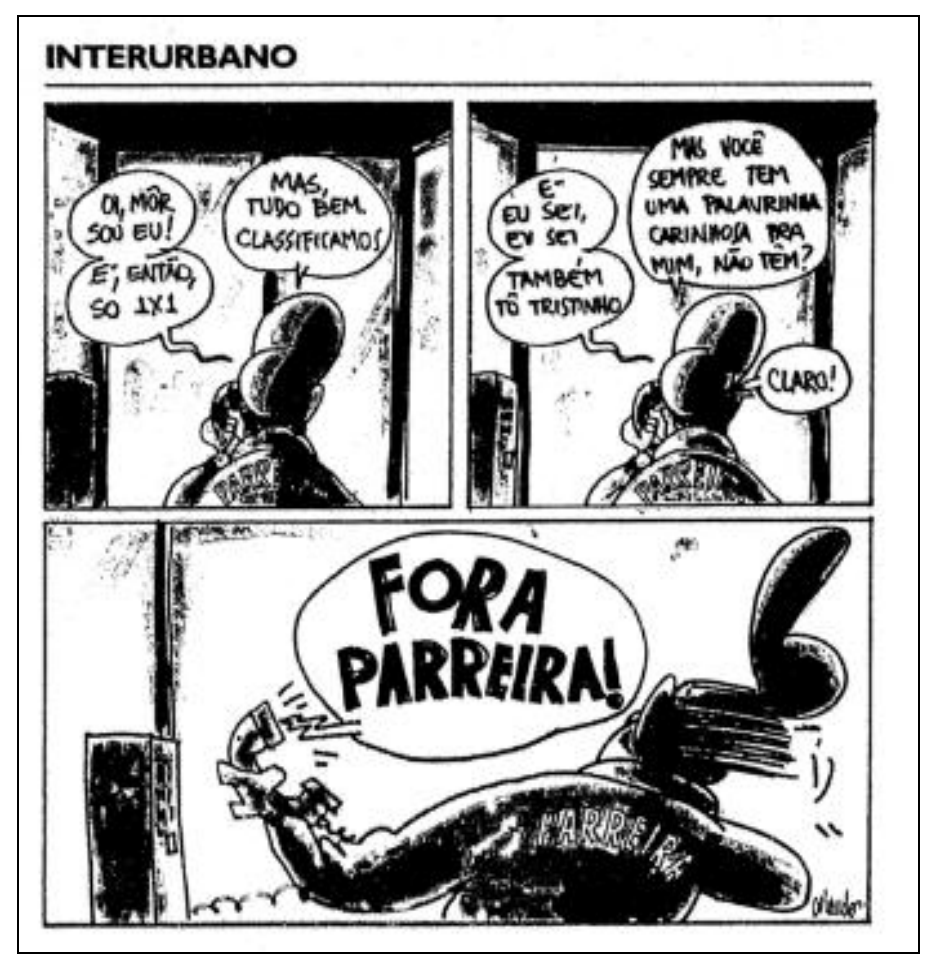

Figura 26 - Fora Parreira - Fonte: Folha de S. Paulo de 30/06/1994 
A charge ${ }^{67}$ é de autoria do cartunista Orlando Pedroso e tem como tema a vitória por 1 a 1 contra a Suécia, que garantiu ao Brasil o primeiro lugar no grupo e a classificação para a fase seguinte. Nela vemos o que seria uma conversa entre Parreira e a esposa, o autor ficcionaliza o âmbito privado da vida do treinador. Só vemos Parreira, que está chamando de uma cabine. O recurso já instaura o insólito porque Parreira transparecia frieza e calculismo. Na charge, ver o personagem que o representa interagindo de forma infantilizada com a esposa é um procedimento que causa graça. A esposa, por sua vez, reage ao pedido de uma palavra carinhosa por parte do técnico como torcedora. Os recursos gráficos presentes no enunciado Fora Parreira! - letras grandes, em negrito, ponto de exclamação -, a forma como Parreira afasta o telefone do ouvido, levam à interpretação de que a esposa o disse gritando, demonstrando que nem entre os familiares ele conseguia apoio.

Apesar da desconfiança, das críticas, a seleção foi eliminando adversários no campeonato e conquistou o título de tetracampeã. A final foi contra a Itália, seleção que também era tricampeã e que o Brasil já havia enfrentado na final da Copa de 1970. Durante a partida, o forte esquema defensivo que ambas as equipes adotaram tirou $o$ brilho do espetáculo (ACAMPORA, 2002) e fez com que o jogo permanecesse 0 a 0 durante o tempo normal e a prorrogação. Pela primeira vez na história das Copas uma final foi disputada nos pênaltis, com as duas seleções exaustas por terem jogado sob um sol de $40^{\circ}$. O goleiro brasileiro Tafarel defendeu um pênalti e Roberto Baggio errou o chute na sua vez, levando o Brasil à vitória por 3 a 2. Na avaliação de Guterman (2014, p. 244), essa vitória em um Mundial de Futebol após 24 anos devolvia ao Brasil $a$ hegemonia do futebol mundial.

Como contraponto a essa atitude que celebrou a conquista do tetra como um "estar de volta ao lugar que merecemos", encontramos no caderno Ilustrada da Folha de S. Paulo, a charge a seguir, publicada dois dias após a partida de encerramento e assinada por Laerte, a qual também reproduzimos e comentamos.

\footnotetext{
${ }^{67}$ A charge, embora esteja no âmbito das produções de humor gráfico publicadas nos jornais, como gênero tem características diferentes das tiras. Entre as principais, citamos o formato e a temática. A charge é maior que a tira e sempre se refere a um tema do noticiário do cotidiano, enfocando-o de forma crítica. Nesse sentido, dialoga abertamente com o discurso jornalístico e com a esfera de atividade jornalismo.
} 


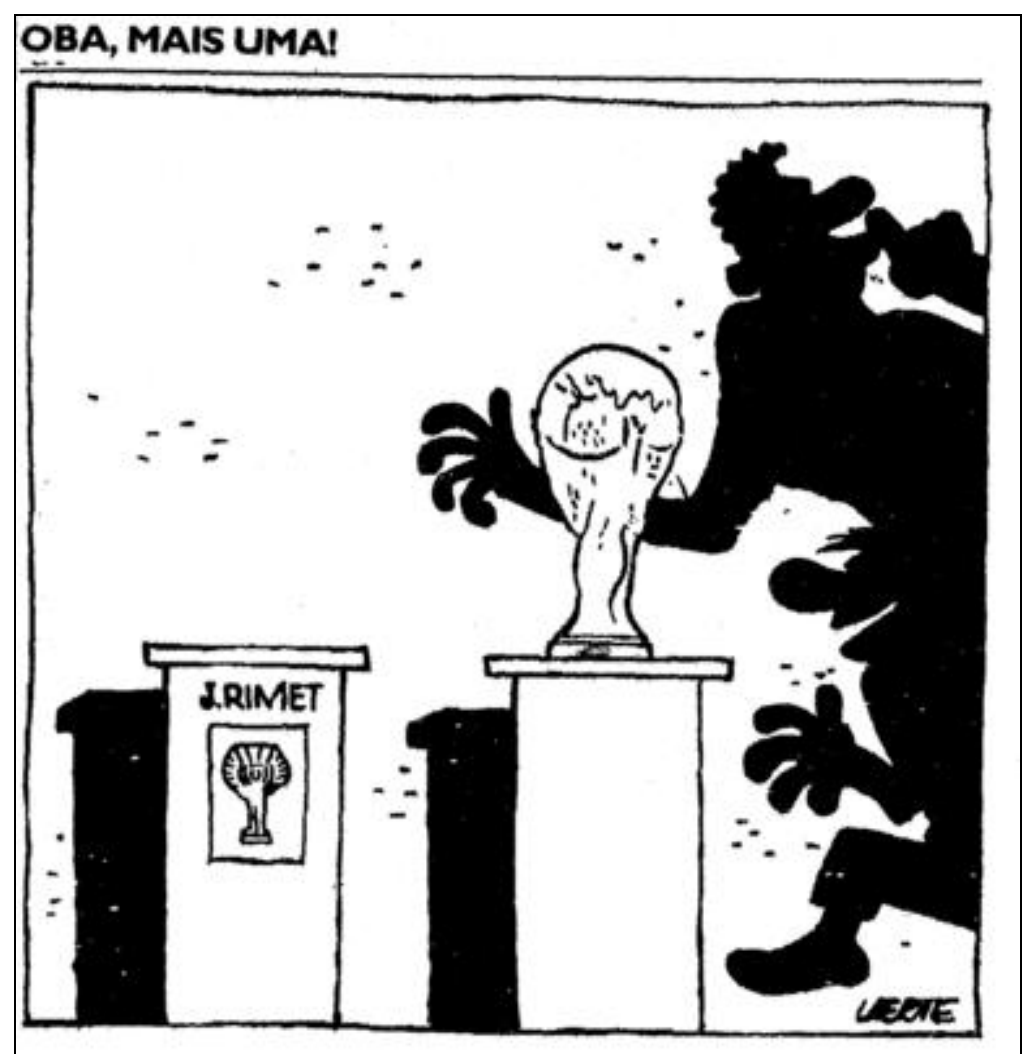

Figura 27 - Mais uma - Fonte: Folha de S. Paulo de 19/07/1994

A charge de Laerte alude ao roubo, ocorrido em 1983, da taça Jules Rimet ${ }^{68}$, que ficara no Brasil como prêmio pela conquista do tricampeonato em 1970. Na imagem, vemos vazio o pedestal identificado com o nome dela. A seu lado, outro pedestal, com o troféu da FIFA simbolizando a copa conquistada. Ao fundo, vemos as sombras de duas pessoas se aproximando sorrateiramente do troféu. Com o título - Oba, mais uma!completa-se o sentido: a conquista do tetra significaria mais uma oportunidade de roubo para os gatunos, que poderiam repetir o que fora feito com a Jules Rimet, ou que a conquista do tetra representaria unicamente isso. Entendendo a charge como um texto e seu autor como o locutor, destacamos a dureza da crítica e o ethos que a produção confere a esse locutor. Além de não celebrar o tetracampeonato, parece-nos que o locutor expressa um ponto de vista de desprezo sobre o que ele representa, na charge o valor simbólico que a taça teria é completamente esvaziado. O locutor coloca-se assim em um lugar de superioridade com relação àqueles que estão no polo oposto, ou seja, os que vibraram com os jogos da Copa e com a conquista. Nesse sentido, o texto traz uma

\footnotetext{
68 O roubo ocorreu na sede da Confederação Brasileira de Futebol em dezembro de 1983. Inacreditavelmente, a taça exposta era a original, enquanto uma réplica ficava guardada num cofre. $\mathrm{O}$ roubo foi planejado por Sérgio Peralta, representante do Atlético Mineiro na CBF e levado a cabo por dois comparsas, Chico Barbudo e Luiz Bigode, que renderam o vigia e levaram a taça, que teria sido derretida por um comerciante de ouro de nacionalidade argentina. Fonte: https://esporte.uol.com.br/futebol/ultimasnoticias/2016/03/06/jornal-fifa-acredita-que-taca-jules-rimet-nao-foi-derretida-e-fara-buscas.htm
} 
contraposição à visão do futebol como algo relevante, polemizando com essa visão. Parece-nos que também está presente aqui um ponto de vista que identificamos em algumas das produções que analisamos - e que retomaremos de forma mais aprofundada na análise - segundo o qual o futebol seria algo menor, ou não merecedor da importância que lhe conferem, por obliterar a realidade ou impedir uma tomada de consciência a respeito dela.

Do quanto exposto nesta seção, parece-nos importante destacar que a conquista do tetracampeonato pela seleção brasileira nos Estados Unidos foi marcada pelo descrédito e por certa rejeição ao futebol que ela jogava. No espaço discursivo da mídia especializada, na argumentação das críticas encontramos a tensão que se estabeleceu entre duas visões sobre como a seleção brasileira deveria atuar em campo. Uma pautada pela técnica - a adotada por Parreira - e a outra, pela genialidade - a defendida por boa parte dos torcedores e da mídia-, que sustentam por sua vez as representações simbólicas amalgamadas respectivamente nas ideias de futebol-força/futebol-máquina e futebol-arte (cf., entre outros, GUEDES, 2006, p. 135). Por outro lado, acreditamos também relevante sublinhar a relação existente entre essa tensão e a ascensão de valores como eficiência administrativa, foco nos resultados, medidas e técnicas para perseguir objetivos etc que haviam passado a vigorar no contexto brasileiro.

\subsubsection{A seleção brasileira, a Copa de 1994 e as tiras da Folha de S. Paulo}

No levantamento que efetuamos no caderno Ilustrada da Folha de S. Paulo durante o período de realização da Copa do Mundo de 1994, encontramos onze tiras que tinham o futebol como tema, três delas de autoria do quadrinista Glauco, e as outras oito de Laerte. Nenhuma delas, no entanto, abordava o desempenho da seleção brasileira, os resultados dos jogos em qualquer uma das etapas ou a conquista do tetracampeonato. Se fossem publicadas em outros dias do ano, igualmente seria possível lê-las e conferir-lhes sentido pois não se baseavam em dados do contexto histórico, ou seja, não eram tiras sobre a Copa do Mundo de 1994 ou sobre o Brasil na Copa de 1994. Assim, visto que não atendiam os critérios que estabelecemos, optamos por não incluí-las no conjunto de tiras analisadas seguindo as categorias e princípios que escolhemos.

Não obstante, nos parece importante reproduzir algumas delas por duas razões: (a) justificar nossa decisão de não tomá-las como material para a análise detalhada; (b) 
embasar nossas hipóteses sobre o porquê da ausência ou do silenciamento a respeito da campanha brasileira na Copa.

Assim, a título de exemplo justificativo, a primeira razão apontada anteriormente, reproduzimos nas figuras 28 e 29 duas tiras de autoria de Glauco.

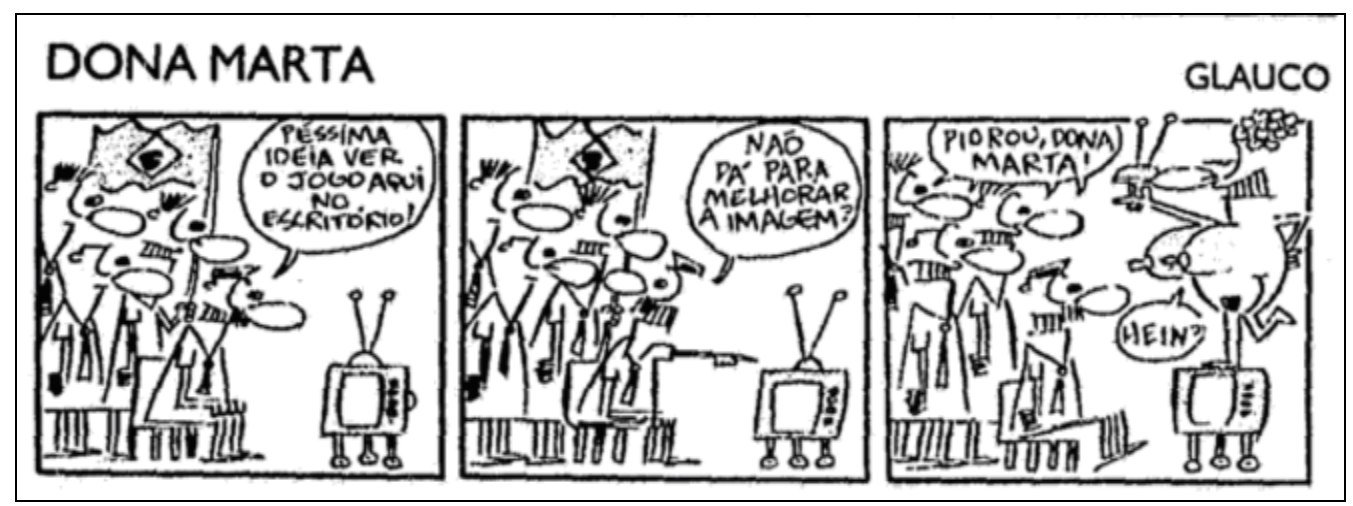

Figura 28 - D. Marta - Jogo no escritório - Fonte: Folha de S. Paulo de 09/07/1994

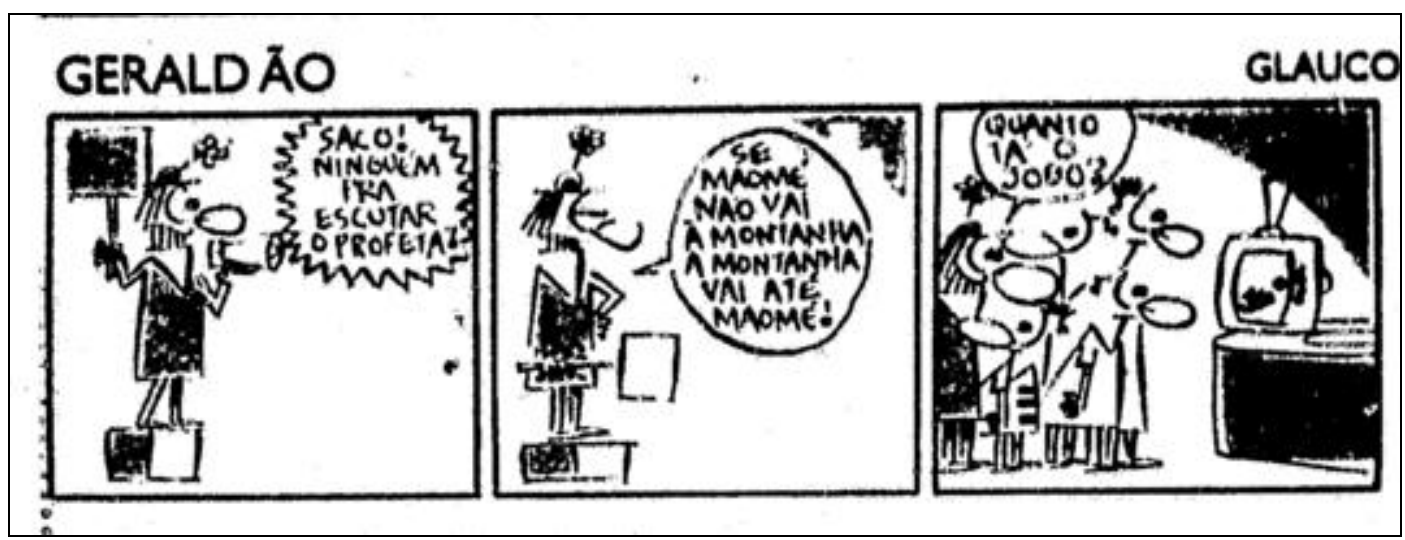

Figura 29 - Zé do Apocalipse - Jogo - Fonte: Folha de S. Paulo de 23/06/1994

Na primeira - Dona Marta - o humor se dá pelas características da personagem que a protagoniza, uma senhora que assedia despudoradamente todos os homens que passam por sua frente e que, quando todos estão reunidos no escritório diante da televisão para assistir um jogo do Brasil, não perde a oportunidade de exibir-se nua em pelo. A segunda, embora identificada como sendo Geraldão, é uma tira do personagem Zé do Apocalipse, um profeta que vive anunciando o fim do mundo. Como ninguém vem escutá-lo, vai ao encontro dos possíveis seguidores e os encontra hipnotizados frente a um televisor. Em lugar de começar a pregar, interessa-se pelo jogo. Em ambas, podemos identificar que está tematizado o interesse que jogos de futebol despertam no Brasil, especialmente os da seleção, a ponto de interromper expedientes ou deixar ruas vazias. Porém não vemos nelas elementos que justifiquem sua classificação como "tiras sobre a 
Copa". Em ambos os casos, como dissemos, poderiam estar referidas a qualquer partida do Brasil. No caso da tira Zé do Apocalipse, inclusive, sequer está claro que se trata de um jogo de futebol.

Quanto à segunda razão, as hipóteses que aventamos para explicar a ausência de produções que tematizassem o desempenho da seleção, a primeira delas é o descrédito com que a torcida brasileira e a mídia durante bom tempo acompanharam a campanha da seleção nos Estados Unidos. Além da não confiança no futebol do grupo comandado por Parreira, acreditamos que as decepções com a eliminação das seleções do Brasil nas Copas de 1986 e 1990, repletas de jogadores talentosos, tenham contribuído para uma certa frieza para com a seleção brasileira em 1994. Um dado que nos auxilia a considerar essa hipótese é que mesmo nas charges que ocupam a seção Quadrinhos da Ilustrada fortemente ancoradas no noticiário cotidiano - o tema da Copa só foi aparecer na produção de Orlando que reproduzimos na figura 26 anterior, em 30 de junho, após a classificação para as oitavas de final.

A outra hipótese que levantamos baseia-se no histórico da produção local de tiras cômicas conjugado com o estilo dos autores que publicavam na Ilustrada naquele momento. Com relação ao primeiro aspecto, recordemos que presença das tiras importadas na Folha de S. Paulo - e talvez em boa parte dos jornais brasileiros - foi hegemônica até recentemente. Em 1994, o espaço destinado diariamente às tiras na Ilustrada era ocupado por oito produções. Quatro delas eram de autores locais, a saber, Angeli, Laerte, Glauco e Fernando Gonsales. As outras quatro eram produções importadas, três autores dividiam o espaço de quatro tiras, eram eles Dik Browne (que assina a tira Hagar), Jim Davis (autor da tira Garfield) e Jim Meddick (autor da tira Robô), ou seja, havia sempre duas tiras de um mesmo autor estrangeiro, o editor se encarregava de fazer o revezamento. Pelas condições de produção das tiras, somente os autores brasileiros poderiam tematizar a Copa ou o desempenho da seleção. Por outro lado - e aqui entra o segundo aspecto, o estilo - Angeli, Glauco e Laerte, a chamada Geração Circo $^{69}$, desenvolveram um modo de lograr o humor em suas produções calcado em tipos urbanos dos anos 80 e 90, personagens da chamada fauna paulistana ou típicos de grandes cidades e daquela contemporaneidade. Nas tiras desses autores, boa parte das situações abordadas se relacionavam à crítica de costumes, poucas vezes foram tematizadas situações do noticiário nacional ou internacional. Fernando Gonsales, por seu

\footnotetext{
${ }^{69}$ Ver o capítulo 4, em que abordamos a cena genérica da tira cômica.
} 
turno, faz o mesmo com um humor baseado em animais como personagens, o rato Níquel Náusea sendo o principal deles. Isso não quer dizer que esses autores não abordassem os temas em outras produções, frisamos que nossa observação se refere às tiras da Ilustrada. Portanto, pressupomos que o estilo imprimido às tiras que esses quadrinistas publicavam, bem como as características de seus personagens poderiam explicar também a ausência de produções em que o desempenho da seleção brasileira ou os resultados da Copa fosse abordado.

Subsidiariamente, como uma ideia que em certa medida dialoga com essa segunda hipótese, identificamos nas produções de um deles um posicionamento crítico com relação ao futebol, já mencionado anteriormente e que também poderia explicar a pouca importância conferida aos eventos da Copa. Trata-se de Laerte, que publicou, como já dissemos, oito tiras que tinham como tema o futebol ao longo da Copa. Selecionamos cinco delas para exemplificar o que estamos afirmando, estão reproduzidas nas figuras 30 a 34 .

PIRATAS DO TIETÊ LAERTE
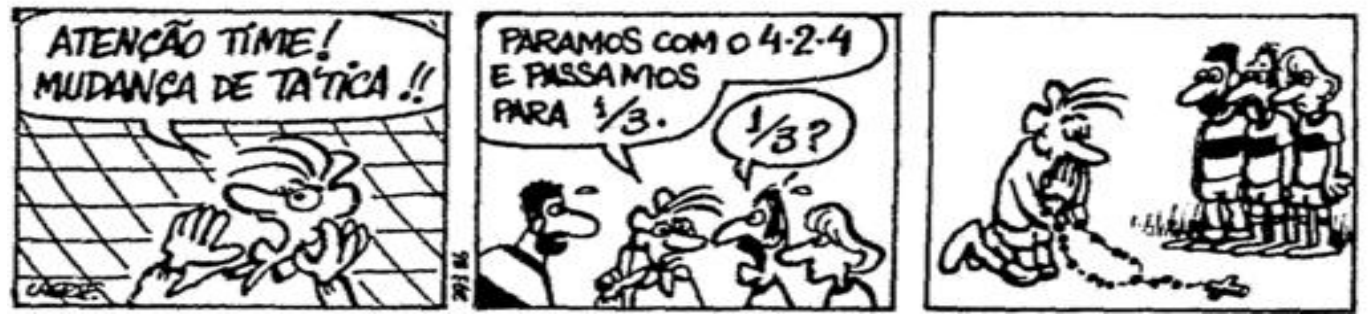

Figura 30 - Piratas do Tietê - Um terço - Fonte: Folha de S. Paulo de 01/07/1994

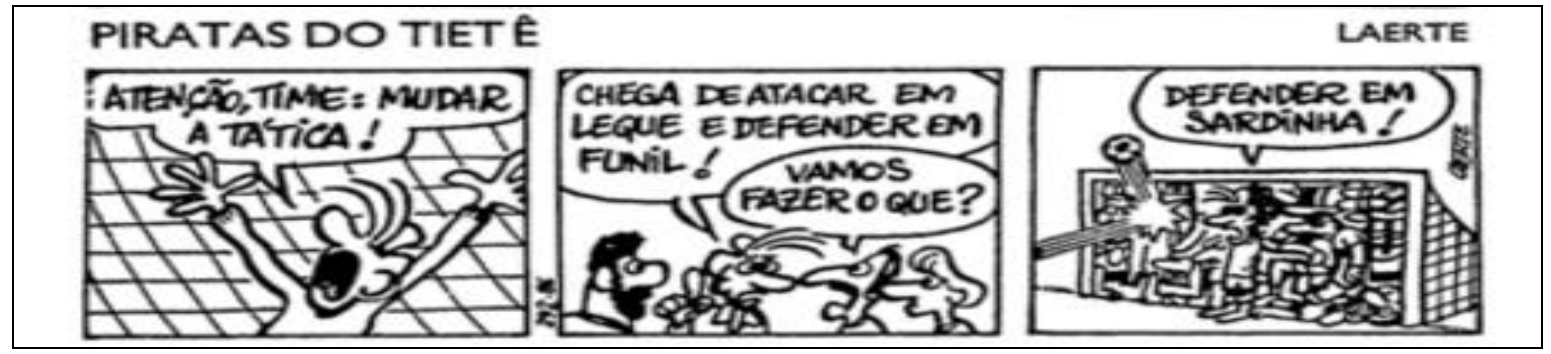

Figura 31 -Piratas do Tietê - Em sardinha - Fonte: Folha de S. Paulo de 03/07/1994 


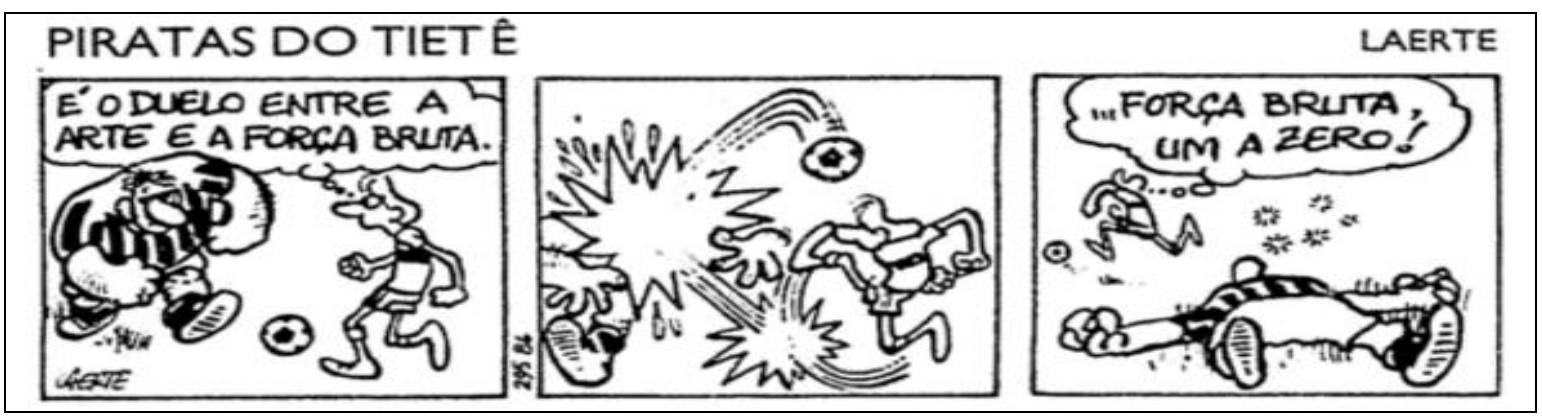

Figura 32 -Piratas do Tietê - Força bruta - Fonte: Folha de S. Paulo de 04/07/1994

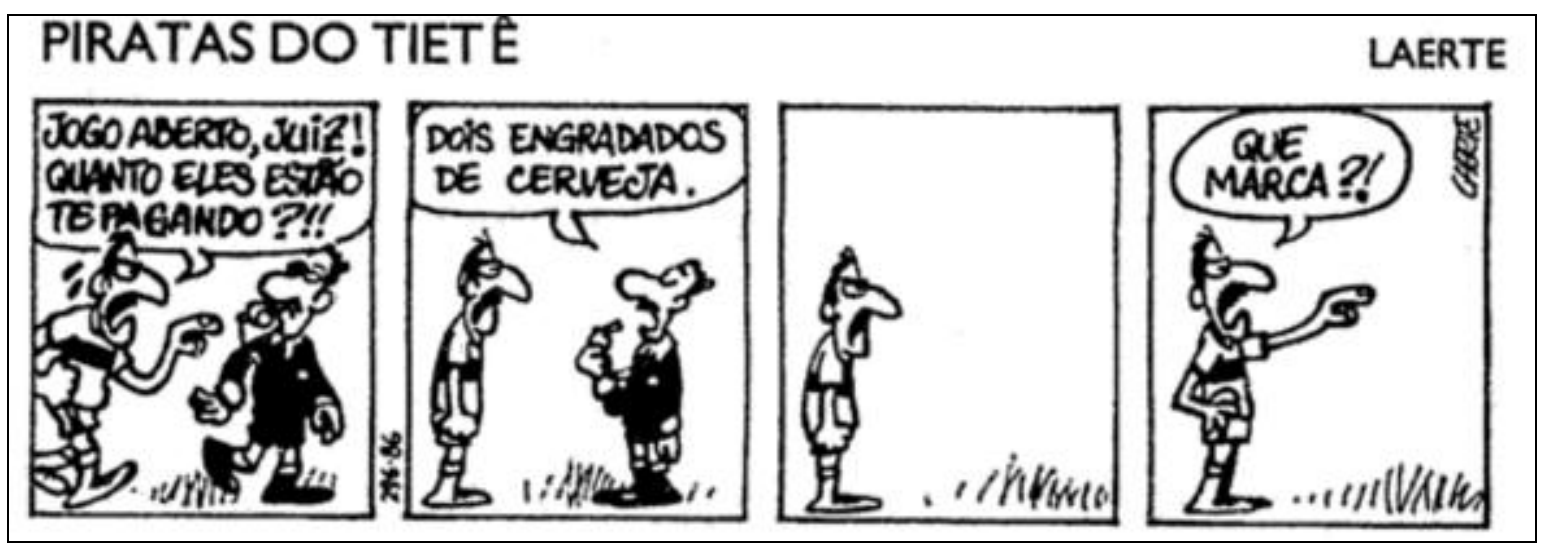

Figura 33 -Piratas do Tietê - Que marca - Fonte: Folha de S. Paulo de 05/07/1994

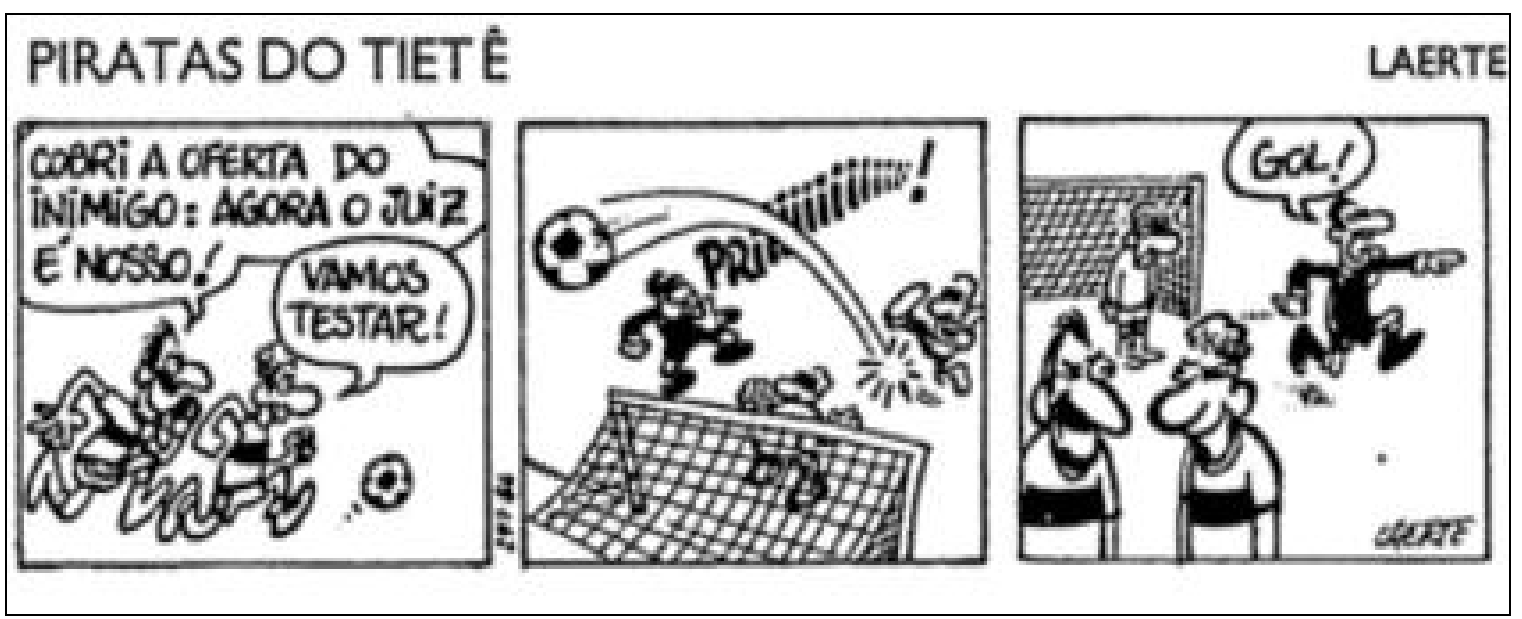

Figura 34 - Piratas do Tietê - Gol - Fonte: Folha de S. Paulo de 06/07/1994

Nas duas primeiras, o humor se dá a partir de um jogo semântico relacionado à nomenclatura dos esquemas táticos do futebol. Na tira da figura 30 , o tema é a distribuição dos jogadores e na da figura 31, a movimentação deles no campo. Em ambos os casos, trata-se de saídas nada ortodoxas, rezar e colocar todo o time dentro do gol, aparentemente para reverter um quadro ruim. Na terceira tira, reproduzida na figura 32 , no duelo entre arte e força bruta, ganha a segunda, com um jogador franzino atacando 
violentamente um grandalhão com cara de poucos amigos. Nas duas últimas, figuras $33 \mathrm{e}$ 34 respectivamente, o humor é construído com base na desonestidade do árbitro, que primeiro revela abertamente o preço para ser corrompido e depois valida um gol que passara por fora da trave. Nesses procedimentos são colocados em causa princípios que norteiam o esporte - a isenção do árbitro, o fair play, as estratégias. Com isso, parece-nos que se opera uma desvalorização e um esvaziamento de seus outros lados, ou seja, de seu potencial impacto ou relevância para a vida em sociedade, de seu valor simbólico no Brasil. Aspectos que, em nosso ponto de vista, conferem ao ethos do locutor dos textos o autor que os assina - uma atitude de superioridade crítica com relação ao futebol e, por conseguinte, à Copa do Mundo, como um evento pelo qual o esporte se converte em centro das atenções em nível mundial e especialmente, nacional. A esse respeito, lembramos que o autor assina também a charge reproduzida na figura 27 anterior, em que a conquista da Copa foi reduzida a mais uma oportunidade para ladrões roubarem a taça. Nesse sentido, podemos talvez identificar esse traço - visão crítica a respeito do futebol como característico do ethos do autor.

Finalmente, gostaríamos de sinalizar que essa ausência, ou o silenciamento, nos interessa na medida em que vemos as tiras de produção local como um gênero que pode nos levar a identificar posicionamentos nos discursos sobre o futebol no Brasil, eventualmente sobre a rivalidade com a Argentina, e por conseguinte, a analisar a relação do esporte com processos que contribuem para nos caracterizar identitariamente. Como esperávamos encontrar a conquista da Copa de 1994 tematizada nas tiras, a ausência nos leva a interpretar as possíveis razões para isso, os sentidos que cria e que expusemos acima.

\subsubsection{Um olhar argentino sobre o tetracampeonato}

Diferentemente do cenário que encontramos na pesquisa com a Ilustrada da Folha, na página de humor do Clarín localizamos produções de Caloi em que o personagem Clemente protagonizava tiras que tematizavam a participação do Brasil na final da Copa de 1994, estão reproduzidas nas figuras 35 e 36. Nelas identificamos nos enunciados efeitos de sentido que dialogam com estereótipos que fazem parte do imaginário a respeito do futebol brasileiro, razão pela qual as comentaremos. Por outro lado, não as analisaremos seguindo a proposta de Charaudeau (2006) porque não foram publicadas no Brasil. No que concerne à investigação dos recursos do humor utilizados e 
seus possíveis efeitos, estamos aplicando essas categorias nas tiras locais que tematizam o desempenho das respectivas seleções, ou seja, das tiras argentinas para os argentinos, das tiras brasileiras para os brasileiros.

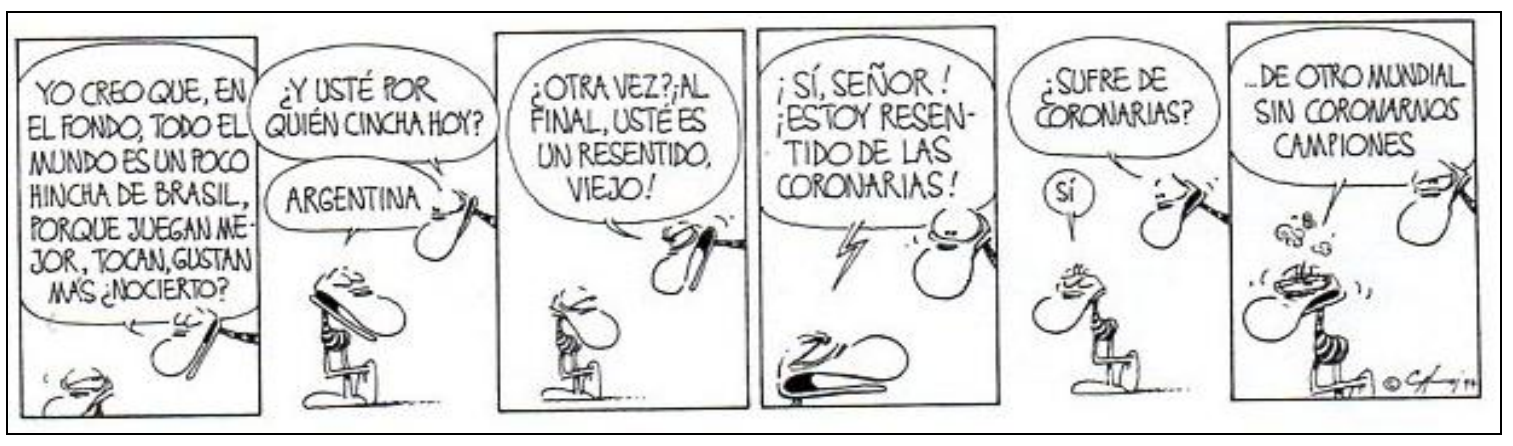

Figura 35 - Clemente - Resentido - Fonte - Clarín de 17/07/1994

Da primeira, publicada em 17/07/1994, chamamos a atenção para a presença de elementos que evocam o estereótipo a respeito do estilo de jogo brasileiro. A cenografia discursiva é a de uma conversa cotidiana, uma troca de opiniões entre duas pessoas sobre a partida que se daria naquele dia. A interação se desenvolve toda no interior ficcional da tira entre Clemente - que chamaremos de locutor-personagem 2 (LP2) - e outro personagem, com o mesmo rosto de Clemente, porém mais alto, de quem não vemos o corpo, e que nomearemos como locutor-personagem 1 (LP1) por ser o primeiro a "falar" na tira. Na primeira vinheta, no enunciado contido no balão-fala do locutor-personagem 1 localizamos ecos das representações já mencionadas sobre o estilo do futebol brasileiro, o do jogo bonito, que encanta (grifo nosso):

LP1: Yo creo que, en el fondo, todo el mundo es un poco hincha de Brasil, porque juegan mejor, tocan, gustan más, ¿no cierto?

Como vemos, segundo o locutor-personagem (LP) 1, essa característica justificaria que todos torcessem pelo Brasil, o jogo bonito despertaria tanta admiração que faria esquecer a qualquer rivalidade. Não há na interação interna uma contraposição explícita a esse ponto de vista, nas duas tiras seguintes, Clemente, o locutor-personagem 2, reage ao fair play do primeiro reivindicando sua disposição de continuar torcendo pela Argentina, que a essa altura já havia deixado a competição. A tira conclui com um jogo de palavras entre coronarias e coronarse campiones que leva ao desfecho humorístico. Com o procedimento linguístico, entra em cena o aspecto emocional do jogo, é possível estabelecer uma relação entre coronarias, o coração e as emoções. 
Embora não tenhamos explicitamente uma contraposição ao ponto de vista do LP1 sobre o Brasil, podemos identificar uma não concordância com ele na resposta do LP2, ao colocar-se tão peremptoriamente disposto a seguir torcendo pela Argentina e, pela expressão de seu rosto na imagem, mostrar-se muito contrariado pela chance do tricampeonato perdida.

O estereótipo do jogo bonito dos brasileiros que identificamos no primeiro balãofala da tira se contrapõe ao discurso da mídia brasileira a respeito do estilo que Parreira imprimira à seleção sob seu comando e que já mencionamos anteriormente. Por outro lado, na tira publicada no dia seguinte, 18/07/1994, que reproduzimos na figura 36, encontraremos ecos desse posicionamento da mídia e dos torcedores.

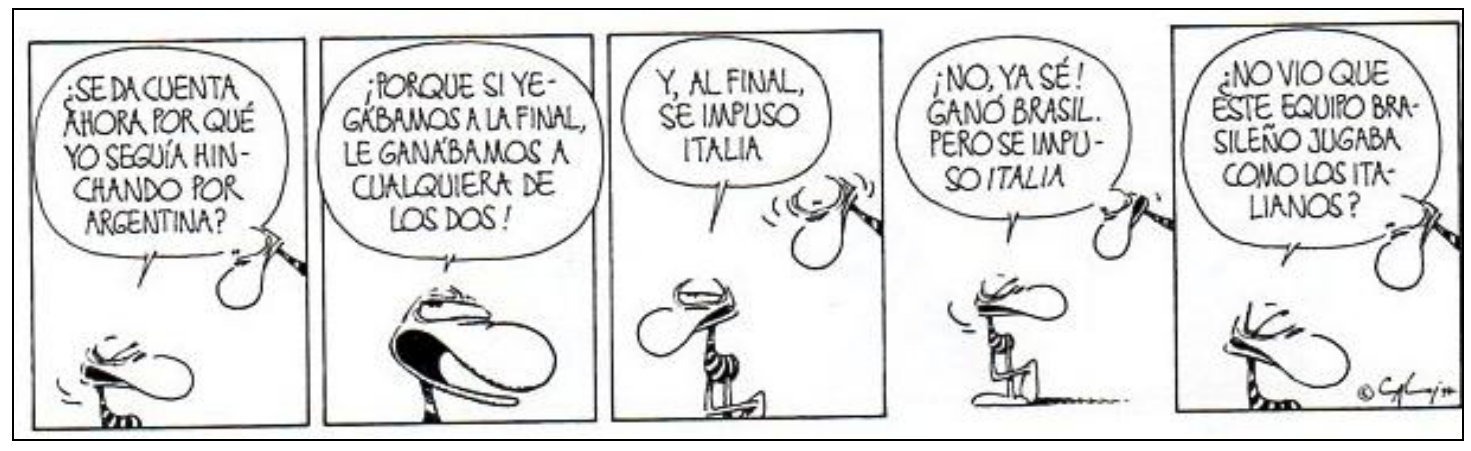

Figura 36 - Clemente -Se impuso Italia - Fonte - Clarín de 18/07/1994

Temos novamente a cenografia de uma conversa cotidiana na qual interagem os dois personagens da tira anterior, porém só Clemente "fala". Como locutor-personagem, na primeira vinheta retoma justamente o universo ficcional da produção do dia anterior, na qual dizia que continuava torcendo pela Argentina, sem se importar com o fato de que a seleção fora eliminada. No enunciado do segundo balão-fala, o locutor-personagem Clemente explica que a razão para tanto era: “iPorque si yegábamos a la final, le ganábamos a cualquiera de los dos!"

Esse enunciado traz um dos mais fortes estereótipos sobre a identidade argentina, a saber, a auto-imagem positiva de superioridade que têm de si na relação com os outros (BORETTI, 2000). Essa auto-afirmação se completa ao longo da tira porque os enunciados do personagem vão construindo um discurso em que a conquista brasileira é rebaixada. No penúltimo balão-fala, afirma que embora o Brasil tivesse ganhado, a Itália havia se imposto. A razão: o time brasileiro jogara como os italianos. Cabe lembrar que nesse jogo final, por estarem se enfrentando uma seleção de um país de Europa e uma de um país da América Latina, simbolicamente também entrariam em campo dois estilos 
opostos de jogar: o europeu, supostamente mais calcado na técnica e na força, e o brasileiro, supostamente mais calcado na habilidade dos craques oriundos do país (GUEDES, 2006, p. 78). Como mencionamos na descrição da partida, o estilo imprimido por Parreira, embora criticado, se manteve e foi se consolidando até a final. O placar de 0 a 0 que levou a decisão para os pênaltis serve como prova de que ambos os times tinham um forte esquema defensivo. Entendemos que ao igualar o estilo de jogo do time brasileiro ao do italiano, Clemente, como locutor-personagem, rebaixa o valor da vitória, tira brilho da conquista dos brasileiros e reverbera a rivalidade Brasil-Argentina. É como se a seleção brasileira tivesse se rendido a um estilo de jogo que não era o seu, tivesse traído a si mesma.

\subsubsection{A modo de retomada}

Contemplamos nesta parte da análise a conquista do tetracampeonato pela seleção brasileira de futebol em 1994. Apresentamos dados sobre o contexto nacional, bem como informações a respeito do estado de ânimo que cercava a participação da seleção na Copa. Estabelecemos um diálogo entre os posicionamentos encontrados e os resultados de estudos sobre o futebol em diversos campos do conhecimento.

Quanto ao gênero que constitui nosso objeto de estudo, no período de realização da Copa de 1994, entre as tiras publicadas na seção de quadrinhos da Ilustrada, embora algumas tivessem o futebol como pano de fundo, segundo nossa visão nenhuma tematizava o evento que tinha lugar nos Estados Unidos ou o desempenho da seleção brasileira.

Nossas hipóteses para essa ausência ou silenciamento são o descrédito com relação à seleção brasileira por parte da torcida e da mídia brasileira, bem como o estilo dos quadrinistas que publicavam na página naquele então, no qual predominavam os tipos urbanos identificados com uma metrópole como São Paulo e a crítica de costumes.

Não obstante não referirem os eventos da Copa, em algumas das tiras do quadrinista Laerte que tinham como tema o futebol encontramos dados que nos pareceram relevantes. Nessas tiras, pelos aspectos que foram mobilizados na construção do humor, interpretamos efeitos de sentido de desvalorização do futebol como esporte ${ }^{70}$.

\footnotetext{
${ }^{70}$ Voltaremos a esse aspecto na análise das produções brasileiras que se referem à Copa de 2014.
} 
Nesta parte da análise, como uma amostra do olhar do Outro para o futebol brasileiro, apresentamos duas tiras de Caloi publicadas na página de humor do Clarín que abordavam a participação do Brasil na Copa. Em ambas identificamos a presença do estereótipo de jogo bonito associado ao estilo de jogo brasileiro, bem como uma crítica à forma de jogar da equipe que disputou o tetracampeonato nos Estados Unidos por vê-la reproduzindo o estilo europeu. Essa crítica reverbera posicionamentos a respeito do estilo imprimido por Parreira como treinador encontrados nos discursos da mídia esportiva brasileiros. 


\section{O caso da Copa de 2014}

\subsection{Aspectos gerais}

\subsection{Antecedentes}

Em 30 de outubro de 2007, na sede da Fifa em Zurique, Joseph Blatter, então presidente da instituição, fez o anúncio oficial de que o Brasil seria o país-sede da $20^{\mathrm{a}}$ edição da Copa do Mundo de Futebol. Ao fazê-lo, disse que o Brasil havia dado ao mundo os melhores jogadores, tinha o melhor futebol e havia conquistado cinco títulos e que por isso a Fifa lhe concedia o direito e a responsabilidade de organizar a Copa de $2014^{71}$.

Visto que o país fora candidato único, a cerimônia não foi marcada pelo suspense, e sim pelo ufanismo. Segundo reportagem assinada por Marcelo Ninio (2007) e publicada na edição do dia seguinte no jornal Folha de S. Paulo, o tom nacionalista da delegação brasileira perdurara desde o discurso de abertura de Ricardo Teixeira, quem presidia a Confederação Brasileira de Futebol à época, até o agradecimento final do presidente Lula. Abundaram promessas de que a Copa seria boa para o país e de que o mundo se surpreenderia positivamente com a competição. Lula declarou ainda que seria uma Copa para argentino nenhum botar defeito ${ }^{72}$, colocando em cena explicitamente nosso eterno outro como sintetizou José Geraldo Couto (2007).

\subsubsection{O período de junho de 2013 a julho de 2014}

O que se deu no intervalo de quase sete anos entre o anúncio e o encerramento do campeonato no Brasil em 13/07/2014, no entanto, não foi exatamente o prometido. Os preparativos e a realização da Copa do Mundo se deram em um contexto social e político dos mais difíceis ${ }^{73}$ da história recente do país, e por isso mesmo dos mais interessantes do

\footnotetext{
${ }^{71}$ Discurso disponível em <https://www.youtube.com/watch?v=rurU1KSF0WM>, acesso em 31/05/2017.

${ }^{72}$ Declaração disponível em < https://www.youtube.com/watch?v=nEd_CVso6iE >, acesso em 31/05/2017.

${ }^{73}$ A nosso ver, entre o encerramento da Copa de 2014 e o momento da escrita deste trabalho o contexto só piorou, instalando-se uma crise profunda e complexa que parece longe de terminar. Lamentavelmente, após manobras políticas e jurídicas que puseram o destino do país nas mãos de representantes dos interesses das elites oligárquicas, temos uma agenda de reformas fundamentadas nos pressupostos do neoliberalismo impostas à população de forma nada democrática. E assim, vemos ser levado a cabo um projeto de país em que a desigualdade e a injustiça social, longe de diminuírem, parece que continuarão sendo a marca da sociedade brasileira.
} 
ponto de vista das reflexões que propicia. Por outro lado, tendo em vista que o objetivo deste trabalho não é exatamente um aprofundamento nesse aspecto, enfocaremos o período a partir de junho de 2013, quando eclodiram as manifestações populares de protesto que ficaram conhecidas como Jornadas de junho de 2013, concentrando-nos no que diz respeito ao nosso tema.

Motivadas inicialmente por aumentos nas tarifas de ônibus, essas manifestações cresceram rápida e exponencialmente em número de pessoas e razões, passando a incluir, além de problemas de mobilidade urbana em geral, a má qualidade dos serviços públicos de saúde e educação, bem como vários aspectos relacionados à realização da Copa: os gastos astronômicos referentes às obras, as exigências da Fifa - quase uma afronta à soberania nacional - e os valores exorbitantes dos ingressos.

Em artigo que integra um livro que discute a Copa de 2014 sob diversos aspectos, o historiador Flavio de Campos (2015) enfoca esse entrelaçamento entre a agenda esportiva e a política que marcaram a realização do evento no Brasil. Conforme o autor (2015, pp.32 e 33), as manifestações retomaram, “com visibilidade, antigas bandeiras dos movimentos sociais, arriadas nos últimos doze anos em nome da governabilidade e do presidencialismo de coalizão". Na retomada de alguns pontos cruciais que desembocaram no descontentamento que marcaram aquele momento, Campos recorda que o prometido legado de desenvolvimento de megaeventos como a Copa "baseado na potencialização turística, na dinamização de serviços e negócios e na melhoria dos transportes públicos das cidades envolvidas" configurava-se evidentemente como uma falácia "diante dos gastos na construção das arenas esportivas e dos resultados limitados em termos de infraestrutura". Além disso, a construção de estádios "padrão-Fifa" em cidades sem expressão futebolística claramente terminariam por transformá-los em uma inutilidade com custos de manutenção altíssimo. Obras essas que, por sua vez, contavam com dinheiro público "por meio de empréstimos subsidiados, renúncia fiscal e até mesmo o custeio direto dos empreendimentos", o que transferiu recursos do Estado para empresas privadas. Campos acrescenta ainda as remoções de populações carentes, o estímulo à especulação imobiliária e sobrecarga de trabalho na execução das obras, que resultaram na morte de operários e em diversos acidentes de trabalho ${ }^{74}$.

Pode-se dizer que as manifestações, com críticas em cartazes e em palavras de ordem passaram a fazer parte do cotidiano da população, especialmente nas cidades que

\footnotetext{
${ }^{74}$ Remetemos à leitura de Fortes (2014) que traz um levantamento mais detalhado a respeito de todos os aspectos aqui apontados.
} 
sediaram jogos. Notava-se claramente uma tensão entre o discurso ufanista e nacionalista da publicidade oficial e o descontentamento de boa parte da população. Tensão que em nada combinava com o clima de festa que se esperava no "país do futebol" por ter sido escolhido, após mais de cinquenta anos, para sediar novamente uma Copa do Mundo.

Para colaborar com o clima de insatisfação, setores da mídia - principalmente os veículos ligados aos grupos hegemônicos da comunicação no país - noticiavam diariamente problemas como atrasos nas obras dos estádios e na infraestrutura de transporte, adensando uma visão pessimista a respeito do evento que se aproximava.

Nesse contexto, na abertura da Copa das Confederações, em Brasilía, que antecedeu em um ano o Mundial de Futebol,

\begin{abstract}
a presidenta Dilma foi vaiada e xingada, no lado de dentro do Estádio Mané Garrincha, por uma maioria de integrantes das classes médias confortavelmente instalada nas cadeiras coloridas da arena esportiva. Do lado de fora, a presidenta foi vaiada por representantes de movimentos populares, que, paradoxalmente, denunciavam também o processo de elitização e de exclusão dos setores subalternos dos espaços destinados à assistência das práticas esportivas (CAMPOS, 2015, p.32).
\end{abstract}

Como se vê, o governo se encontrava em meio a um fogo cruzado, como alvo do descontentamento inclusive dos setores da população que o apoiavam. A cena dos xingamentos chulos à presidenta voltou a se repetir em São Paulo, na cerimônia da abertura oficial da Copa, mas dessa vez por parte daqueles que puderam pagar os altos preços dos ingressos. Campos (2015) vê a ferocidade presente nesses atos como sendo "a expressão de descontentamentos, frustrações e divergências ideológicas que pareciam ter sido superadas pelo grande pacto social costurado em torno de Lula e Dilma” (p. 33). De nossa parte, acrescentamos que, se por um lado é fato que o descontentamento com a Copa vinha dos mais diversos setores da sociedade, por outro a virulência e o desrespeito com que a mandatária legal e democraticamente eleita do país foi atacada nos estádios revelaram o lado mais sombrio e nefasto de grande parte da classe sócio-econômica brasileira mais favorecida.

Na contramão do que pareciam esperar certos setores da população no Brasil, a Copa de 2014 no país teve êxito e foi elogiada. No entanto, é inegável que a realização do evento terminou por expor problemas e conflitos existentes no tecido social nacional que, como aponta Campos (2015), diferentemente do que por um tempo se acreditou, continuavam apenas latentes e de forma alguma superados. É o que também afirma Rocco Júnior (2015, p. 11-12) na apresentação da obra que vimos citando, para quem a escolha do Brasil como sede da Copa de 2014 trouxe à baila "as principais contradições de uma 
jovem nação que ainda amadurece em suas instituições políticas, sociais e econômicas". $\mathrm{O}$ autor conclui que por meio do futebol foram evidenciadas de forma clara contradições históricas da sociedade brasileira. Essa mesma posição tem Campos (2015, p.38), e nos alinhamos com ele, para quem o futebol e sua importância para a sociedade brasileira propiciaram que os profundos conflitos de interesse que marcam nossa sociedade fossem expostos, o que o leva a concluir que o maior legado da Copa de 2014 talvez tenha sido justamente o "enfrentamento político com o Brasil diante do espelho", como bem demonstra essa charge da série Aqui na Esquina, de autoria de Luli Penna, publicada na seção Quadrinhas da Folha de S. Paulo de 16/06/2014.

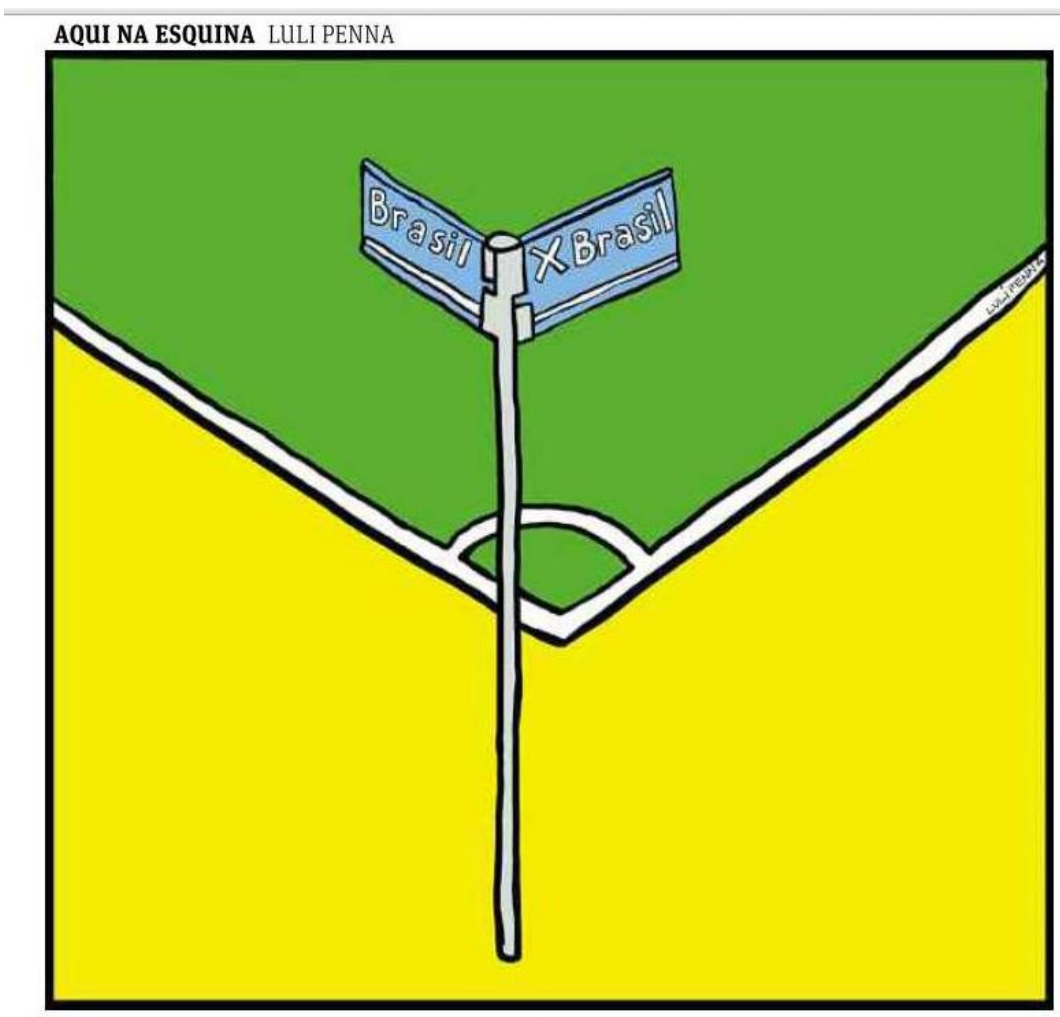

Figura 37 - Aqui na Esquina - Brasil x Brasil - Fonte: Folha de S. Paulo de 16/06/2014

A produção sintetiza com muita propriedade o peculiar contexto em que se deu a Copa de 2014. Nela vemos representados os principais elementos que o compunham: um campo de futebol com as cores nacionais - representação da coletividade homogeneizada na ideia do Estado-nação Brasil. Em lugar da bandeirinha de escanteio, um poste de esquina com placas de rua. Nelas se lê Brasil X Brasil, plasmando-se assim a divisão do país, a disputa e o enfrentamento a que se refere Campos e que citamos anteriormente.

No cenário descrito, a derrota acachapante da seleção brasileira para a seleção alemã na fase seminal da Copa acabou contribuindo para acirrar os ânimos dos setores 
descontentes com o governo federal e segundo alguns, como Carvalho e Zilberman (2017), influenciado nos acontecimentos que se seguiram após as eleições de novembro de 2014. De nosso ponto de vista, embora seja inegável o papel que o futebol desempenhou no cenário político e no resultado das eleições, nos parece pouco provável que uma vitória do Brasil pudesse ter evitado os fatos que se seguiram e cujos resultados ainda estamos vivendo.

Do quanto exposto, nos parece importante destacar a impossibilidade de separar a Copa de 2014 do recente contexto político e social brasileiro, mais uma vez vimos o futebol entrelaçado à história do país. Como de forma muito feliz sintetizou Campos (2015) no título de seu artigo, o Mundial de Futebol de 2014 no Brasil foi a Copa da política em um país do futebol.

As tensões e a cisão vividas no país naquele momento e que acabamos de resumir são tema das produções às quais nos dedicamos no próximo item.

\subsection{Embates nas ruas, embates nas tiras}

\subsubsection{O pintinho - Esporte nacional}

A primeira tira que analisamos é de autoria de Alexandra Moraes e foi publicada na Folha de S. Paulo em 16/06/2014, na segunda-feira seguinte à abertura da Copa, realizada em 12/06/2014. Nessa ocasião a presidenta Dilma foi vaiada e insultada, como já comentamos anteriormente. A tira faz parte do projeto Quadrinhas, ao qual também já nos referimos ${ }^{75}$, em que só autoras publicavam às segundas-feiras e está reproduzida abaixo na figura 38 .

\footnotetext{
${ }^{75}$ Ver capítulo 4.
} 


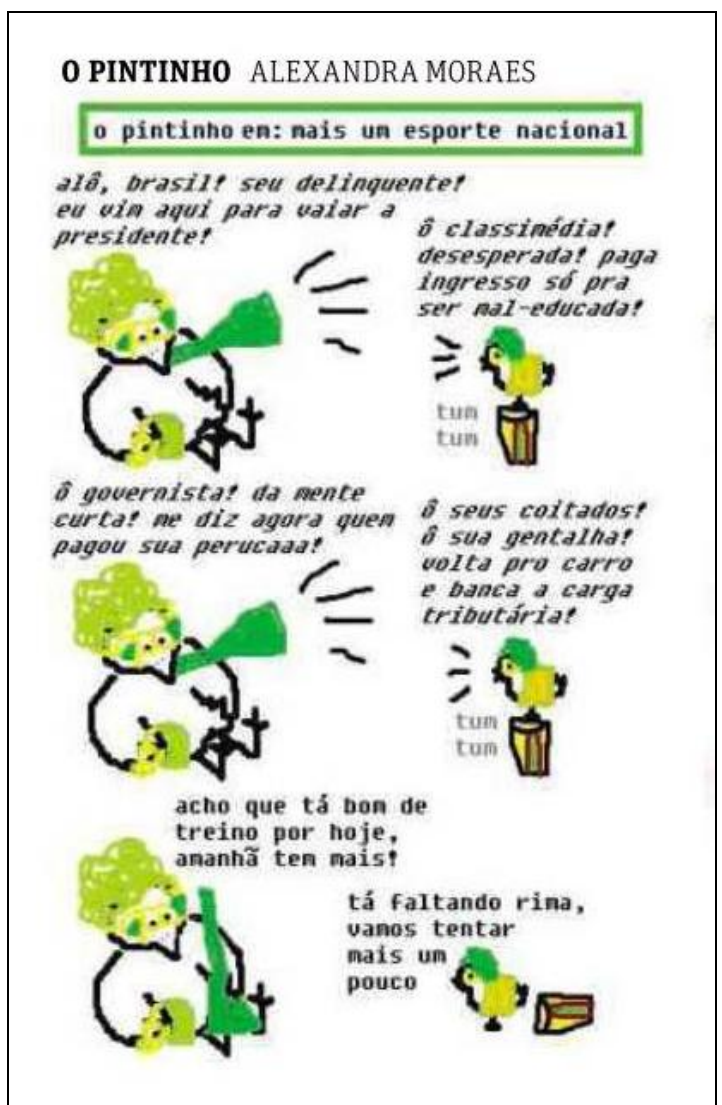

Figura 38 - O Pintinho - Mais um esporte Fonte: Folha de S. Paulo de 16/06/2014

Como podemos observar, trata-se de uma tira que trabalha seus aspectos gráficos de forma inovadora. Sua orientação é sempre vertical e normalmente as cenas não são delimitadas por vinhetas, também não há balões-fala, na verdade temos os chamados balões-zero (RAMOS, 2009, p. 39). A autora realiza os desenhos com o programa Paint Brush, um aplicativo para desenho do sistema Windows, o que lhe confere um aspecto pixelado ${ }^{76}$ característico. Os personagens são fixos, uma galinha, a mãe, que interage com seu filho, um pintinho.

$\mathrm{Na}$ produção de que nos ocupamos, os personagens aparecem com alguns adereços verde-amarelos, a mãe toca uma corneta e o filho um tambor, há linhas cinéticas que saem da corneta e da boca do pintinho. Os itens citados funcionam como elementos de representações estereotípicas que circunscrevem a tira no universo temático da Copa para o leitor. Além do título da tira e da autoria, essa produção específica traz também um

\footnotetext{
${ }^{76} \mathrm{O}$ pixel é a menor unidade de uma imagem digital, o termo vem da contração das palavras picture e element. Ao visualizarmos uma imagem com alto índice de aproximação, é possível identificar pequenos quadrados coloridos nela, que, somados, formam o desenho completo. Uma imagem pixelada é aquela em que podemos identificar os pequenos quadrados que a formam. Fonte: https://www.tecmundo.com.br/imagem/203-o-que-e-pixel-.htm
} 
título, destacado em verde, nele se lê "o pintinho em: mais um esporte nacional", que funciona como uma legenda.

No plano da interação entre os personagens, em lugar de encontrar enunciados que remetam às conversas entre mãe e filho frequentes na tira, nas duas primeiras cenas o leitor se depara com uma sequência de interjeições, vocativos e rimas que recordam os cantos das torcidas nos estádios, ou seja, o gênero canto de torcida aparece parodiado na organização textual dos enunciados e é essa a cenografia instaurada, um confronto entre duas torcidas. Em lugar de estarem enfrentadas duas equipes adversárias, no entanto, estão enfrentados simbolicamente dois posicionamentos ideológicos. Embora não tenhamos explicitamente particitações (MAINGUENEAU, 2008b, 2014), entendemos que podemos aplicar neste caso o conceito de hiperenunciador de Maingueneau (2008, 2014), ou seja, um enunciador que representa uma entidade coletiva, no caso, um posicionamento ideológico. Se aliamos Ducrot (1987) a Maingueneau (2008, 2014) encontramos uma polifonia complexa em que temos, além dos locutores-personagens (LP), pelo menos dois (hiper)enunciadores que representam dois posionamentos ideológicos distintos.

A galinha dá voz a um hiperenunciador que identificaremos como HE1; o pintinho, por sua vez, dá voz a um segundo, que identificaremos como HE2. Assim temos:

HE1 - Alô, Brasil! Seu delinquente! Eu vim aqui pra vaiar a presidente!

HE2 - Ô, classimédia! Desesperada! Paga ingresso só pra ser mal-educada!

HE1 - Ô, governista! Da mente curta! Me diz agora quem pagou sua peruca!

HE2 - Ô seus coitados! Ô sua gentalha! Volta pro carro e banca a carga tributária!

LP1 - Acho que tá bom de treino por hoje. Amanhã tem mais.

LP2 - Tá faltando rima. Vamos treinar mais um pouco.

Vemos a voz do HE1 representando, dentro da chave do humor, os setores mais conservadores da população, que estavam explicitamente contra o governo e suas pautas sociais, aqueles que poderíamos classificar sob o rótulo "a direita".

O HE2, por sua vez, vemos como a voz que representa os setores da população que, alinhados ideologicamente com o governo, questionavam justamente a opção por um 
modelo de evento excludente e intensificador de desigualdades, os quais, seguindo o procedimento anterior, classificaremos como "a esquerda" 77.

Tal como nos cantos de torcida (cf. GÁNDARA, 1997), temos nos enunciados desta tira uma desqualificação, sempre na chave do humor, do outro ao qual estão dirigidos:

(a) HE1 sobre HE2: seu delinquente, governista da mente curta

(b) HE2 sobre HE1: classimédia desesperada, mal-educada, coitados, gentalha

Parece-nos que em (a) pelo uso de delinquente como uma forma nominal para referir-se aos "adversários", a desqualificação se dá a partir de um lugar de superioridade moral. Destacamos ademais, na comparação semântica com os outros insultos, o valor bem mais negativo que delinquente traz consigo, pois atribui ao outro uma conduta criminosa.

Maingueneau $(2008,2014)$ a partir também do trabalho de Gándara (1997) afirma que no caso dos cantos de torcida, invoca-se o pertencimento a uma tradição, já no dos slogans militantes, trata-se de um hiperenunciador que sinaliza o empenho com uma causa. Tendo em vista que nesses enunciados a desqualificação do outro emerge do pertencimento de cada um desses grupos a posicionamentos políticos opostos, e consequentemente o comprometimento com causas distintas, entendemos que de alguma forma está presente também o hiperenunciador dos slogans militantes. Essa percepção dialoga com o apontado por Campos (2015, p. 25) em sua análise do contexto político e social da Copa de 2014. Nela o autor afirma que "do ponto de vista da estética das massas, da sua gestualidade e da sua vocalidade, as manifestações e toda a extensa pauta que se construiu nas ruas brasileiras mimetizaram as expressões das arquibancadas". Para corroborar seu entendimento, que entendemos acertada, apresenta uma série de exemplos de slogans e cantos entoados nas manifestações que seriam calcados naqueles cantados pelas torcidas. Ratificando essa percepção, notemos que tem sido frequente usar a expressão Fla-Flu, termo popularizado pelo jornalista Mario Filho para referir-se ao clássico em que se enfrentam as duas grandes torcidas cariocas, para descrever a situação de polarização e hostilidade declarada entre grupos com posicionamentos políticos

\footnotetext{
${ }^{77}$ Por várias razões, hesitamos em usar as denominações esquerda e direita. As principais são: não haver a homogeneidade que os rótulos supõem e não encontrarmos em nenhum dos campos enfrentados no Brasil consistência ideológica política que possa ser classificada sob essas denominações, tal como elas se configuraram historicamente.
} 
distintos que se vive desde 2013 no Brasil $^{78}$. Curiosamente, Alabarces (2006) faz a mesma observação em relato sobre as manifestações ocorridas em Buenos Aires em dezembro de 2001 motivadas pela grave crise política e econômica que enfrentava o país. O autor, involuntariamente, acabou tomando parte da primeira manifestação e assim expressa suas impressões:

En un momento, miré hacia la escalinata del Parlamento y murmuré para mí: "es una tribuna". El colorido, pletórico de los colores celeste y blanco; la actitud corporal de los manifestantes, agitando sus brazos rítmicamente mientras seguían los cánticos; y las mismas estrofas, trabajadas sobre las melodías típicas de los estadios, recordaban las tribunas populares de los estadios de fútbol argentinos (op. cit. p.199).

A observação, além de ser mais um dado no entrelaçamento entre política e futebol, também acrescenta um elemento no conjunto de semelhanças e diferenças estabelecidas quando comparamos Brasil e Argentina.

Retomando nosso objeto de análise, o título presente na legenda - que identificamos como a voz do narrador - também vai ao encontro da interpretação expressa nas linhas anteriores. Nesse sentido, ofender-se mutuamente por razões políticas teria se convertido em "mais um esporte nacional", à semelhança do futebol e como tal precisa ser treinado, como expresso nos enunciados dos locutores-personagens nas suas últimas intervenções.

Para finalizar, alinhavaremos o exposto com a construção do humor na tira e seus possíveis efeitos. Valendo-nos das categorias propostas por Charaudeau (2006) para o ato humorístico, entendemos que ele ocorre nessa produção pelo procedimento que autor classifica como um jogo enunciativo paródico. O leitor precisará identificar o gênero e a situação que estava sendo parodiada, extrair dela os implícitos, construir a interpretação e, por conseguinte, o humor. Ao mesmo tempo, pelo exagero caricatural presentes nos insultos, vemos também o jogo enunciativo sarcástico.

No complexo ato de linguagem que significa a leitura desta tira, interagem vozes, instâncias enunciativas, procedimentos interdiscursivos e uma série de representações, com a finalidade de colocar em causa as atitudes dos grupos polarizados no contexto de realização da Copa no Brasil, ridicularizando-as. Nesse sentido, entendemos a conivência

\footnotetext{
${ }^{78}$ A título meramente ilustrativo, uma busca com o sintagma "fla-flu político" no mecanismo de busca Google retornou mais de 2.500 resultados. No Google Acadêmico, a mesma busca retornou 5 resultados.
} 
crítica como um efeito possível para o humor nessa produção. Entendemos que os grupos representados e suas atitudes constituem o alvo do humor.

\subsubsection{Chico Bacon - Não vai ter Copa e Estádio lindo}

As próximas tiras que analisaremos são de autoria de Caco Galhardo e foram publicadas duas semanas após o início da Copa. Nelas está tematizada a situação de conflito vivida pelos brasileiros enquanto torcedores, divididos entre torcer pela seleção e posicionar-se criticamente contra o que implicou a realização da Copa no país. As tiras estão reproduzidas nas figuras 39 e 40 a seguir.

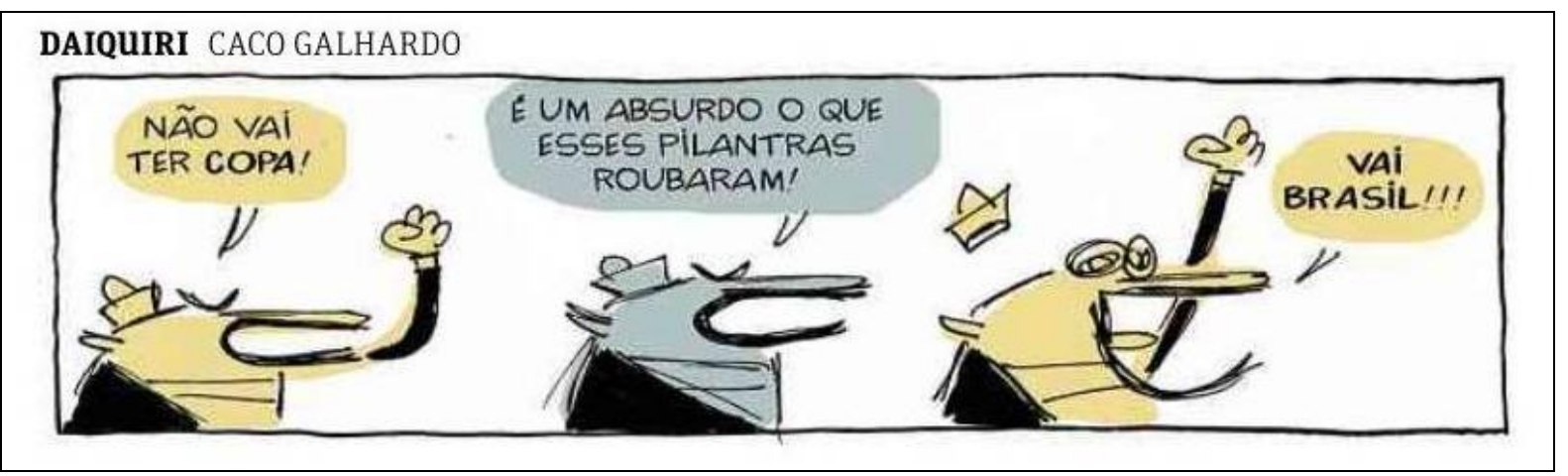

Figura 39 - Chico Bacon - Vai Brasil - Fonte: Folha de S. Paulo de 25/06/2014

\section{DAIQUIRI CACO GALHARDO}

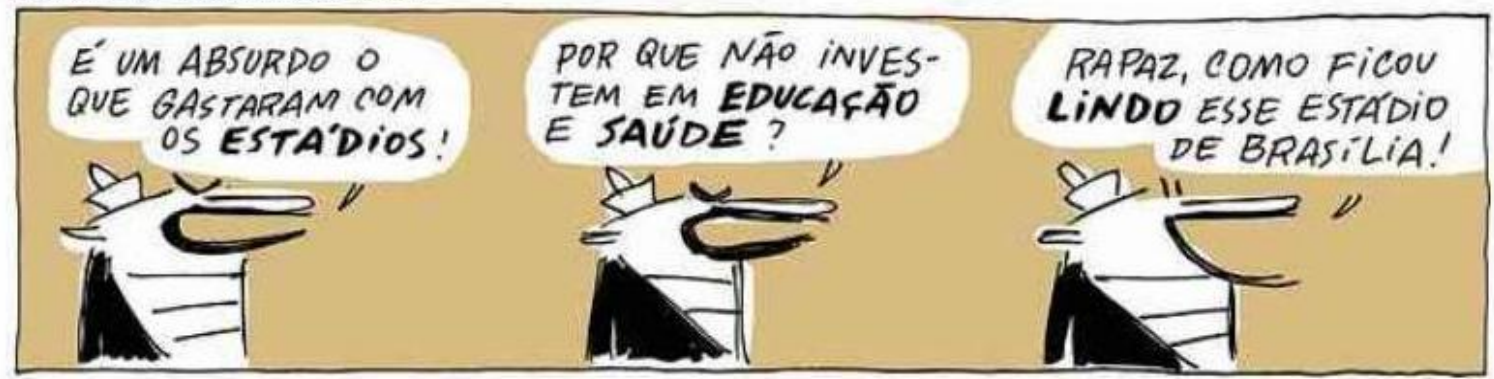

Figura 40 - Chico Bacon - Vai Brasil - Fonte: Folha de S. Paulo de 27/06/2014

As duas são muito semelhantes na estruturação da narrativa e na cenografia construída, razão pela qual as abordaremos em conjunto. São protagonizadas pelo personagem Chico Bacon em uma sequência de três cenas, que não estão delimitadas em três vinhetas diferentes, ou seja, não existe linha de contorno. Tampouco existem outros elementos na construção do cenário da narrativa, só vemos o personagem. 
Vamos nos deter nas duas primeiras cenas de ambas as tiras. O personagem primeiramente é representado expressando descontentamento: o cenho está franzido, a boca é desenhada aberta como se estivesse gritando, protestando. Dirige-se a algo ou a alguém, que não está presente nas cenas. Na primeira delas, tem o braço erguido com o punho fechado, poderia estar em uma manifestação de protesto. Outro ponto a chamar a atenção é que na segunda cena dessa mesma tira (Figura 39) ele é retratado com outra cor, detalhe que retomaremos na interpretação. Passando à parte verbal, nos balões-fala podemos identificar os enunciados que circulavam no cotidiano brasileiro no período anterior à Copa, especialmente a partir de junho de 2013, já comentados no item 2.1.2 anterior. Nas duas primeiras cenas das duas primeiras tiras, observamos, portanto, uma congruência entre as semioses verbal e não verbal, as quais situam o leitor numa cenografia que remete às manifestações de protesto, especificamente aquelas contra a Copa.

Passemos para as últimas cenas das tiras, que introduzem um dado novo nas vozes presentes até o momento e marcam uma mudança. Do ponto de vista não verbal temos o personagem retratado com sinais de contentamento: a boca está aberta como que gritando, mas os lábios desenham uma curva que mostra alegria. Essas imagens diferem um pouco mais entre si nas duas tiras.

$\mathrm{Na}$ da figura 39, a imagem de Chico Bacon mostra mais efusividade que na da figura 40: seu chapéu parece voar, os olhos estão grandes e de dentro da boca sai um desenho que poderia ser a língua ou a úvula, detalhe que representa a intensificação do grito. Quanto à parte verbal, o enunciado do seu balão-fala é a exortação típica do torcedor assistindo qualquer competição em que o Brasil está representado. Observamos portanto uma quebra de expectativa. A cenografia da terceira cena, o assistir um jogo, é completamente diferente da construída nas duas primeiras, que remetiam aos protestos daquele contexto histórico.

Já na terceira cena da figura 40, pelo enunciado do balão-fala do personagem, ele, como locutor, em lugar de contestação e crítica, expressa reconhecimento e admiração diante de um dos estádios, justamente o tipo de obra que era objeto dos protestos. A contradição que se dá em ambos os casos causa o efeito humorístico das produções.

Passando às vozes presentes nestas produções, identificamos que o personagem Chico Bacon como locutor dá voz a um enunciador (E1) e a dois hiperenunciadores (HE), sobre os quais passaremos a discorrer. 
Na figura 39 vemos a seguinte configuração:

HE1: Não vai ter Copa!

E1: É um absurdo o que esses pilantras roubaram!

HE2: Vai Brasil!!!

Começando pelo HE1, para melhor compreendê-lo será necessário discorrer brevemente sobre o enunciado Não vai ter Copa!. Tomando-o nas situações nãoficcionais em que se deu a conhecer, ou seja, os protestos que tiveram lugar entre junho de 2013 e junho de 2014, trata-se de um exemplo de uma particitação militante (MAINGUENEAU, 2008, 2014) que, por sua vez, nos coloca em contato com um hiperenunciador, cuja caracterização, no sentido de identificar os valores que aglutina é complexa. Embora se trate claramente de um slogan militante, nascido num regime de enunciação aforizante, não é possível precisar com exatidão a origem do enunciado. $\mathrm{Na}$ tentativa de refazer sua história, identificamos que grupos com posicionamentos muito diferentes se apropriaram dele. Nesse sentido, entre junho de 2013 e junho de 2014 era possível ver o slogan circulando em diferentes atos, entre integrantes dos mais diversos movimentos, tanto os de inspiração anarquista, como o Anonymous ${ }^{79}$, até coletivos ligados a partidos de esquerda de oposição ao PT, tais como como o Partido Socialismo e Liberdade (PSOL) e o Partido Socialista dos Trabalhadores Unificados (PSTU) ${ }^{80}$. Podemos falar, portanto, em sentidos que o enunciado Não vai ter copa adquiriu e que abarcavam também este espectro: desde o enfrentamento explícito com o objetivo de barrar a realização da Copa até uma demarcação de posição, com consciência de que àquela altura era impossível impedir a realização do evento. Assim, no contexto das manifestações, tendo em vista a heterogeneidade de posicionamentos dos participantes que as integravam acreditamos que podem ser identificados diferentes hiperenunciadores para o mesmo slogan militante, segundo os grupos que o enunciavam. Entendemos que a transposição desse slogan para o discurso humorístico na tira apaga todas essas nuances, temos o locutor-personagem Chico Bacon dando voz a um hiperenunciador que representa simplesmente todas as vozes que contestavam a realização da Copa.

\footnotetext{
79 No item "Quem Somos" do site Anonymous Brasil, definem-se com uma ideia, negam que tenham qualquer tipo de organização ou lider, bem como vinculação com qualquer partido político, orientação religiosa, interesse econômico ou ideologia. Suas principais bandeiras são a liberdade total de expressão e o combate à centralização de poder e a verticalização de seu exercício. http://www.anonymousbrasil.com/sobre-anonymous/. Acesso em 07/06/2017.

${ }^{80}$ Conforme informações disponíveis em <http://www.ihu.unisinos.br/entrevistas/532259-como-o-malestar-se-exprimira-depois-da-copa-entrevista-especial-com-rodrigo-nunes/>e http://apublica.org/2014/02/quem-grita-nao-vai-ter-copa/. Acesso em 07/06/2017.
} 
No que concerne ao E1, seu enunciado expressa um ponto de vista a respeito de uma situação e a ausência de modalizadores lhe confere valor de asserção. Atentando para as escolhas lexicais da oração adjetiva "que esses pilantras roubaram" e retomando o contexto histórico ao qual nos estamos referindo, ou seja, a situação de comunicação dessa tira especificamente, vemos que refletem um posicionamento político diferente daquele que o HE1 congrega. Como se sabe, pilantra é sinônimo de ladrão, trapaceiro. Quanto ao sintagma nominal "esses pilantras", nesse enunciado ele pode ter como referente um coletivo de diferentes atores sociais que abarca o governo, a Fifa, as empreiteiras, os políticos em geral. O verbo que se segue fala por si. Assim, chamamos a atenção para o fato de que o enunciado reflete um posicionamento dos grupos mais conservadores que eram oposição ao governo desde sempre. A questão central de dissensão, por parte dos grupos que contestavam a realização da Copa por não verem coerência entre o ideário político do PT, como partido que estava no poder, e os encaminhamentos para que o megaevento acontecesse, era a prioridade de investimentos. Não identificamos, ao menos naquele momento, que esses grupos fizessem uma associação explícita entre esses gastos e a corrupção. Por outro lado, questionamentos sobre a lisura de caráter dos líderes do partido foi uma das acusações frequentemente dirigidas ao PT em geral por parte dos setores mais conservadores da sociedade. Assim, o locutor-personagem nesse caso traz a voz de um enunciador com posicionamento diferente do HE1. Interpretamos que a mudança da cor com que o personagem é retratado contribui para marcar a diferença.

Passemos finalmente para o hiperenunciador que identificamos como HE2. O enunciado "Vai, Brasil" no plano ficcional instaura um pertencimento a uma situação em que se torce pela equipe que representa o Brasil em uma competição, entendemos portanto que se trata de uma particitação. O hiperenunciador que ela implica representaria uma abstração: o torcedor brasileiro que vibra, exorta, aplaude, enxerga simbolicamente a seleção como parte de algo que lhe constitui, não importando que isso seja uma construção e esquecendo-se de qualquer uso político que possa existir ${ }^{81}$.

\footnotetext{
${ }^{81}$ Embora tenha se dado em um contexto completamente diferente, essa cisão nos remeteu à Copa de 1970 que ocorreu em plena vigência da ditadura e patrocinada por ela. Os que se posicionavam contra o regime se viram presos em um dilema que poderíamos resumir em que torcer pelo Brasil era compactuar com a ditadura. Por outro lado, conforme destaca Guterman (2014, p. 162), "a magia de Pelé, Jairzinho e companhia era irresistível". O cartunista Henfil tematizou a dubiedade de sentimentos em um cartum que reproduzimos no apêndice.
} 
Passando à tira reproduzida na figura 40, no que se refere às vozes presentes nela, temos um panorama menos diversificado do que o da tira que acabamos de analisar. Entendemos que nesta temos a seguinte configuração:

E1: É um absurdo o que gastaram com os estádios!

E1: Por que não investem em educação e saúde?

LP: Rapaz, como ficou lindo esse estádio de Brasília!

Identificamos os dois primeiros enunciados como provenientes de um mesmo posicionamento ideológico, os setores da sociedade que contestavam a realização da Copa pela inversão na prioridade de investimentos que representou. Quanto ao terceiro, tendo em vista o ethos do personagem, o vemos proferido pelo próprio locutor-personagem Chico-Bacon. O substantivo "Rapaz" no enunciado funciona como uma interjeição, uma marca que faz emergir o que poderíamos chamar de a subjetividade do personagem, identificada também no adjetivo "lindo".

Em ambas as tiras, vemos tematizada a dualidade de sentimentos vivida pelos torcedores brasileiros durante a Copa de 2014. Por um lado, posicionar-se criticamente frente à inversão de investimentos que o megaevento representou diante da realidade dos profundos problemas do país. Por outro, o desejo de abandonar-se às emoções que envolvem o ato de torcer e a viver simbolicamente o possível triunfo da seleção. De nosso ponto de vista, o recurso de não demarcação das vinhetas colabora para evidenciar que a oscilação entre uma posição e outra eram um continuum no tempo e espaço e não momentos estanques, a dubiedade de sentimentos estava o tempo todo imbricada. Entretanto, em ambos os casos parece ser que a emoção de torcer acaba prevalecendo.

No que se refere à construção do humor, entendemos que ele se dá pelo jogo enunciativo paródico, que toma como base as situações de protesto daquele momento. Como alvo, o já citado comportamento de parte dos torcedores, divididos entre torcer e criticar, entre a emoção e a razão. Alvo que poderia incluir também o próprio interlocutor, ou melhor, o leitor como ser do mundo também afetado pela dualidade de sentimentos. Como efeito possível para o ato de humor vemos a conivência crítica, pela exposição da contradição, tornando-a motivo de ridiculização. Tendo em vista como ambas as tiras terminam, o contra-argumento evidenciado seria que a paixão do torcedor acaba prevalecendo. 


\subsubsection{A modo de retomada}

Nesta seção, descrevemos o contexto em que seu a Copa de 2014 no Brasil, para isso tivemos de retroceder aos protestos que tiveram início em junho de 2013 abordando sua relação com a realização do evento no país. Vimos que a forma como foi encaminhada a realização do evento no país, atendendo à concepção de megaevento esportivo pautada pela Fifa, terminou por deixar à mostra contradições, divergências, antagonismos que estiveram silenciados durante o governo anterior. Com isso, futebol e política se entrelaçaram no desenrolar de acontecimentos que marcam a história recente brasileira.

A situação retratada foi abordada em três tiras publicadas no período da Copa. Nelas vimos tematizado o episódio dos insultos dirigidos à presidenta Dilma durante a abertura do evento e os protestos contra a realização da Copa no país. Pudemos identificar nas tiras vozes que representavam diferentes posicionamentos políticos e ideológicos. Verificamos ademais a ambiguidade de sentimentos que vivia parte da população enquanto torcedores, uma vez que para alguns torcer pela seleção do Brasil identificavase com posicionar-se a favor da Copa e, por conseguinte, do governo. Dessa forma, também nas tiras verificamos o entrelaçamento entre política e futebol mediante exemplos de particitação em que se mesclavam hiperenunciadores de cantos de torcida e de slogans militantes.

No quadro abaixo resumimos nossa interpretação quanto aos procedimentos encontrados seguindo a classificação de Charaudeau para os atos de humor, bem como seus efeitos possíveis para com o interlocutor.

\begin{tabular}{|c|c|c|c|c|c|c|c|}
\hline \multirow[b]{2}{*}{ Produção } & \multicolumn{7}{|c|}{ Procedimentos } \\
\hline & 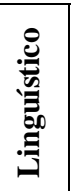 & 兽 & 尊 & 范 & 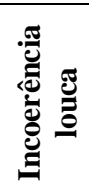 & 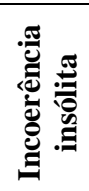 & 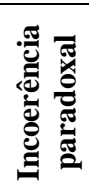 \\
\hline $\begin{array}{l}\text { O Pintinho - Esporte nacional } \\
\text { (Figura 38) }\end{array}$ & & & $\mathbf{x}$ & $\mathbf{x}$ & & & \\
\hline $\begin{array}{l}\text { Chico Bacon - Vai Brasil } \\
\text { (Figura 39) }\end{array}$ & & & & $\mathbf{x}$ & & & \\
\hline $\begin{array}{l}\text { Chico Bacon - Estádio lindo } \\
\text { (Figura 40) }\end{array}$ & & & & $\mathbf{x}$ & & & \\
\hline
\end{tabular}




\begin{tabular}{|l|c|c|c|c|}
\hline \multirow{2}{*}{ Produção } & \multicolumn{3}{|c|}{ Efeitos possíveis } \\
\cline { 2 - 5 } & $\begin{array}{c}\text { Conivência } \\
\text { lúdica }\end{array}$ & $\begin{array}{c}\text { Conivência } \\
\text { crítica }\end{array}$ & $\begin{array}{c}\text { Conivência } \\
\text { cínica }\end{array}$ & $\begin{array}{c}\text { Conivência } \\
\text { de derrisão }\end{array}$ \\
\hline $\begin{array}{l}\text { O Pintinho - Esporte nacional } \\
\text { (Figura 38) }\end{array}$ & & $\mathbf{x}$ & & \\
\hline $\begin{array}{l}\text { Chico Bacon - Vai Brasil } \\
\text { (Figura 39) }\end{array}$ & $\mathbf{x}$ & & \\
\hline $\begin{array}{l}\text { Chico Bacon - Estádio lindo } \\
\text { (Figura 40) }\end{array}$ & $\mathbf{x}$ & & \\
\hline
\end{tabular}

Relacionando esses dados às produções analisadas, o humor pelo jogo paródico talvez se explique por estarem tematizados acontecimentos recentes do noticiário. Parecenos ademais que o humor nessas tiras evidencia para seus emissores um ethos de observadores atentos e críticos dos acontecimentos do país e dos atores sociais que deles participam. No caso das produções de Caco Galhardo (figuras 39 e 40), ao não encontrarmos elementos como o sarcasmo, a derrisão, entendemos que a criticidade se dá de forma não agressiva e violenta. No caso da produção de Alexandra Moraes (figura 38), os alvos do humor são ridicularizados, o que coloca o emissor em uma posição de superioridade para com eles.

Na próxima seção, dirigimos nosso olhar para os acontecimentos da competição esportiva propriamente dita. Abordaremos a derrota do Brasil para a Alemanha e a conquista do vice-campeonato pela Argentina.

\subsection{O Brasil na Copa de 2014}

A seleção brasileira chegou pré-classificada à Copa de 2014. Como o país seria a sede do campeonato, foi dispensada de participar dos jogos eliminatórios.

A equipe jogou sob o comando de Luis Felipe Scolari, o Felipão, convocado após a demissão de Mano Menezes, que por sua vez havia assumido depois de Dunga, que estivera à frente da seleção na bastante questionável campanha da Copa de 2010.

Tendo em vista o imaginário que cerca o futebol no Brasil, o histórico da conquista de cinco medalhas e o fato de o país ser o anfitrião, as expectativas com relação ao desempenho da seleção na Copa de 2014 eram altíssimas. E foram frustradas da pior forma possível.

Em 8 de julho de 2014 a seleção amargou uma derrota humilhante de 7 a 1 para a Alemanha, resultado que passou ao campo discursivo do futebol como "a pior derrota da 
história da seleção brasileira". Muito embora existissem - e existem - diferenças substanciais entre os dois eventos, a data acabou sendo chamada de Mineiraço, à semelhança do Maracanaço de $1950^{82}$. Uma dessas diferenças diz respeito à confiança que os torcedores depositavam na seleção em 1950. Costa (2014), por exemplo, relembra que diferentemente de 1950, o desempenho da seleção comandada por Luis Felipe Scolari até as quartas de final não havia sido muito convincente, portanto uma derrota para a Alemanha era uma possibilidade razoável no horizonte. A autora acrescenta que a expectativa negativa era alimentada sobretudo pela ausência de Neymar, o principal jogador brasileiro e em quem Felipe Scolari apostava todas as suas fichas. O jogador santista, na partida anterior contra a Colômbia, havia fraturado uma vértebra após uma falta violenta do jogador Zuñiga e fora cortado do Mundial. Por outro lado, apesar da pouca confiança no desempenho do time e da ausência de Neymar, o que de forma alguma se esperava era um resultado com uma diferença de placar tão considerável, em um jogo de Copa do Mundo no qual uma das equipes era a seleção do Brasil.

Nas manchetes do dia seguinte as palavras mais recorrentes eram vergonha, humilhação, vexame, massacre, fiasco ${ }^{83}$. Ainda segundo Costa,

Em relação a ênfase na palavra "vexame" e "humilhação" é válido frisar que essas palavras frequentemente usadas para se definir o resultado Alemanha 7 x Brasil 1, são palavras que fazem referência ao abalo de uma hierarquia, pois têm como pano de fundo o glorioso histórico da seleção brasileira em Copas do Mundo.

Parece-nos que o paradigma estabelecido nos discursos a respeito do impacto da derrota enfatizava não só o abalo de uma hierarquia, como afirma Costa, como também que o abalo se dera de forma desonrosa, afetando a dignidade da seleção, os dotes simbólicos que a tornavam merecedora da torcida.

É oportuno dizer que posteriormente o resultado acabou sendo substantivado e usado no linguajar cotidiano como sinônimo de adversidade, situações desagradáveis,

\footnotetext{
${ }^{82}$ Remetemos à leitura de um texto que o historiador André Alexandre Guimarães Couto publicou em seu blog, poucos dias após a derrota, no qual faz uma breve reflexão a respeito de como a imprensa retomou a derrota para o Uruguai na Copa de 1950 para noticiar o resultado do jogo contra a Alemanha, e sobre a pertinência ou não dessa comparação. Texto disponível em https://historiadoesporte.wordpress.com/2014/07/13/por-que-nao-esquecemos-de-1950/. Acesso em 20/06/2017.

${ }^{83}$ No portal B9 encontra-se um texto em que foram reunidas 50 capas de jornais publicados no Brasil no dia seguinte à derrota. Material disponível em http://www.b9.com.br/50229/brasil/50-capas-de-jornais-brasilapos-derrota-de-7-x-1-para-a-alemanha/. Acesso em 02/06/2017.
} 
atos que impliquem em ganho ou derrotas simbólicas, como podemos verificar nos exemplos:

Executivos e artistas contam como lidam com um "7 a 1" profissional ${ }^{84}$

Logo, desde fevereiro de 2015, o desempenho das ações dos dois principais bancos privados do país pode ser considerado um "7 a 1 ", 85

O 7 a 1 de Anitta em Waack e nos fiscais do bom gosto na Rio $2016^{86}$

Na sequência dos acontecimentos, a seleção ainda foi derrotada pela Holanda na disputa pelo terceiro lugar. A partir do que se seguiu, à semelhança do que Campos (2015) aponta sobre o legado da Copa para o Brasil, podemos dizer que talvez o legado do triste resultado da seleção brasileira em 2014 seja a oportunidade de confrontar-se com a realidade do futebol atual, e constatar que é muito diferente daquela que possibilitou a construção do imaginário sobre a seleção canarinho.

\subsubsection{A seleção brasileira, a Copa de 2014 e as tiras da Folha de S. Paulo}

Nesta seção, seguindo os mesmos procedimentos analíticos já expostos nas seções anteriores, abordaremos produções publicadas no jornal Folha de S. Paulo no período entre 10/07/2014, pouco depois do jogo contra a Alemanha, até 15/07/2017, dois dias após o encerramento da Copa. O critério para selecioná-las foi terem como tema o desempenho do Brasil na Copa de 2014 ou o próprio evento no período citado, seis tiras atendiam esses critérios. Começaremos por uma produção de Caco Galhardo, parte da série Daiquiri, reproduzida na figura 41.

\footnotetext{
${ }^{84}$ http://classificados.folha.uol.com.br/empregos/2014/07/1484900-executivos-empresarios-e-artistascontam-como-lidam-com-um-7-a-1-profissional.shtml Acesso em 02/06/2017

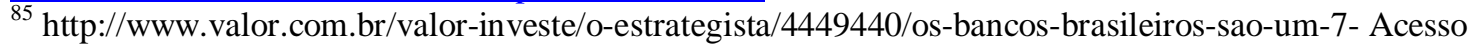
em $02 / 06 / 2017$

${ }^{86} \mathrm{http}$ ://www.diariodocentrodomundo.com.br/lidas-de-2016-o-7-a-1-de-anitta-em-waack-e-nos-fiscais-dobom-gosto-na-rio-2016-por-kiko-nogueira/ Acesso em 02/06/2017
} 


\subsubsection{Chico Bacon - Soterrado}

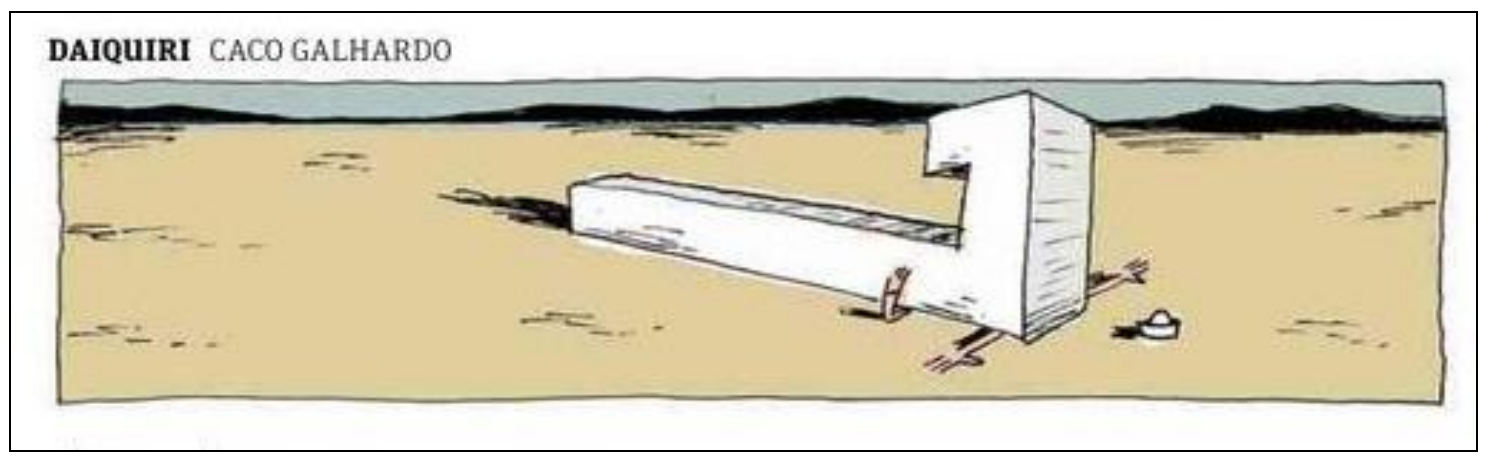

Figura 41 - Chico Bacon - Soterrado - Fonte: Folha de S. Paulo de 10/07/2014

Trata-se de uma produção peculiar, uma tira em uma só vinheta composta somente por imagens, não há elementos verbais. Ademais, na composição desse texto ${ }^{87}$, constatamos que há pouquíssimos elementos na cena retratada. A primeira coisa que atrai o olhar do leitor é um número sete, gigantesco como se fosse um monumento, tombado no chão. Como não há nenhum pedestal, é como se houvesse caído do céu. Sob ele veemse braços e pernas, alguém foi soterrado; o chapéu permite deduzir que se trata do personagem Chico Bacon, que vinha protagonizando como torcedor várias tiras relacionadas à Copa ao longo do período anterior. Devemos lembrar que essa identificação é possível porque Chico Bacon é um personagem frequente das tiras que Caco Galhardo publica diariamente. Nesse sentido, no universo ficcional da tira, o chapéu funciona como um índice ao qual o leitor deverá relacionar o personagem Chico Bacon. Como fundo, vemos uma paisagem desértica, nada mais do que o solo e o horizonte ao fundo.

Embora a tira não esteja dividida em vinhetas que representem as cenas de uma narrativa, há uma dimensão temporal no texto imagético. Há um antes implícito. No plano da ficção interno, esse antes é o fato de que anteriormente o personagem não estava sob o monumental sete. Mas não estamos diante de um mero retrato de um fato ficcional. É preciso ir além da superfície da imagem. Para construir um sentido para o texto dessa tira é necessário localizar seu tema, que acontecimento está comentando. Seu sentido só se completa na referência aos acontecimentos da Copa. Na hipótese de que viesse a ser publicada numa coletânea, provavelmente teria de ser acompanhada de uma informação paratextual para localizar o leitor. Nesse processo, entendemos que a chave para recuperar o referente desse texto é justamente o numeral sete, sem que isso signifique ignorar o

\footnotetext{
${ }^{87} \mathrm{O}$ termo está sendo usado compreendendo qualquer produção semiótica que pertence a uma prática discursiva (cf. MAINGUENEAU, 2008a, p. 139).
} 
papel que os dados da situação de comunicação em que o gênero está inserido (suporte, finalidade, inserção na temporalidade etc) desempenham concomitantemente. Assim, o tema é a derrota brasileira e o foco é o número de gols que a seleção sofrera.

Por outro lado, no plano do simbólico, não se trata de uma imagem em que um sete cai sobre um personagem. O ethos do personagem Chico Bacon configura-se com características que o assimilam a um torcedor aniquilado pelo número de gols que a Alemanha fez contra o Brasil em 08/07/2014, e aqui o uso do nome do país que cada seleção representava é intencional. Uma vez que se trata do Brasil, de brasileiros, de uma Copa realizada no país, entra em funcionamento todo um imaginário simbólico em que o desempenho da seleção é igualado ao país e, por conseguinte, afeta seu povo, enquanto uma construção que representa um coletivo homogêneo. Entendemos, portanto, que simbolicamente o leitor, se torcedor, pode se identificar com personagem Chico Bacon.

Enfocando agora as instâncias que participam do ato humorístico como um ato de enunciação (cf. CHARAUDEAU 2006), identificamos o torcedor brasileiro como o alvo do ato de humor. Desta sorte, trata-se de um ato de humor em que tanto seu emissor como seu destinatário são potenciais alvos, pois tanto o leitor quanto o autor, que coincide com Caco Galhardo como ser do mundo, podem ocupar o lugar social de torcedores.

Outra particularidade desta tira é que não há exatamente uma virada para o humor. O humor está justamente no inusitado, no insólito presente na forma como a situação da derrota é retratada, configurando o que Charaudeau (2006) classificou como um procedimento discursivo da ordem do lógico-semântico, a incoerência insólita. Temos dois universos de sentido (o dos acidentes e o do jogo de futebol), postos em relação. Entendemos que não se trata do que o autor classificou como incoerência sem sentido embora a fronteira entre ambas ele mesmo admita ser muito tênue -, porque é possível estabelecer com certa facilidade a conexão entre os dois universos: para o torcedor o resultado de um jogo pode ser tão impactante quanto um acidente. Como recursos para o efeito humorístico temos a exageração caricatural com que o autor compõe a cena, a assemelhação entre o efeito da derrota sobre o torcedor e ser soterrado por um bloco gigantesco em forma de sete que cai do céu. Atentemos nesse sentido para o tamanho do número sete, o peso que parece ter, o silêncio eloquente que a ausência de outros elementos confere à cena, incluindo o apagamento do único gol marcado pelo Brasil. $\mathrm{O}$ impacto foi tão surpreendente que o personagem não conseguiu sequer gemer. Tudo isso nos remete à repercussão emocional do 7 a 1: a derrota foi tão acachapante que deixou a todos momentaneamente anonadados. 
Quanto aos efeitos possíveis do ato de humor (cf. CHARAUDEAU, 2006), acreditamos que podemos encontrar como mais em evidência o efeito classificado pelo autor como conivência lúdica, aquela em que o destinatário (o leitor) é convidado a partilhar uma visão lúdica com o emissor do ato humorístico (o quadrinista), em uma fusão emocional entre ambos, partindo do primeiro. Trata-se de mostrar um olhar inusitado para as surpresas do mundo, sem qualquer compromisso moral. Como efeito possível, a conivência lúdica, no caso que analisamos, leva ao destinatário-leitor um olhar bem-humorado para o impacto da derrota, que, como já dissemos, pode ter afetado a ambos, posto que tanto o emissor como o destinatário podem ocupar o papel social de torcedor, alvo desse ato de humor. Nesse sentido, nos parece que podemos falar de um ethos solidário para o emissor, visto que seu texto comenta o aspecto emocional da derrota, sem qualquer outra análise a respeito, como se não houvesse nada mais a fazer senão abandonar-se à sensação de aniquilamento.

As três tiras que abordaremos a seguir trazem pontos de vista bem diferentes. Nelas, como veremos, a derrota é vista de forma mais negativa. Encontramos também vozes que trazem os diferentes posicionamentos dentro do campo discursivo do futebol no Brasil, já mencionados no item 2.12 anterior, em que abordamos o contexto de realização da Copa de 2014.

\subsubsection{Malvados - Realidade, não}

A próxima produção que enfocaremos está reproduzida na figura 42, é de autoria de André Dahmer e foi publicada no dia 10/07/2013.

\section{MALVADOS ANDRÉ DAHMER}

\section{palestra sobre os novos tempos}

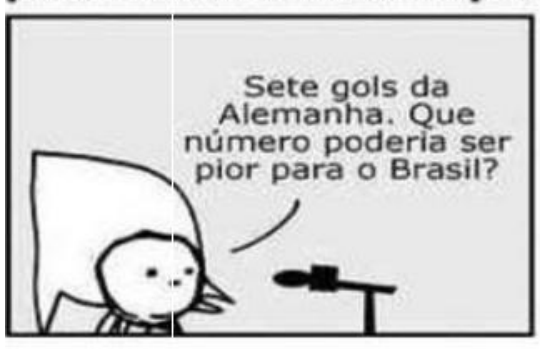

Figura 42 - Malvados - Realidade, não - Fonte: Folha de S. Paulo 10/07/2014

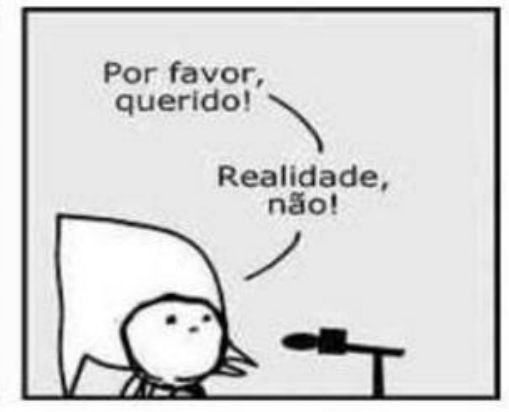

Trata-se da tira Malvados, cujos protagonistas são dois seres difíceis de definir: um maior, o Malvadão, e outro menor, o Malvadinho. Algumas pessoas os identificam 
como flores, mas o autor não confirma essa classificação ${ }^{88}$. Na tira em análise vemos só um deles, o Malvadinho. Embora essa informação sobre os personagens esteja no âmbito dos saberes construídos pelos leitores assíduos da tira, pelo título Malvados mesmo um leitor não habitual poderá antecipar que encontrará elementos relacionados à maldade de alguma forma. Nesse sentido, tocando em informações sobre o estilo do autor, podemos dizer que no ethos dos personagens a maldade está presente em um espectro que vai da ironia crítica ao sarcasmo mais cruel.

Essa produção faz parte de uma série, "Palestra sobre os novos tempos". Nela o personagem aparece sempre em tiras de três vinhetas diante de um microfone, sem quaisquer outros elementos ao fundo. Implicitamente, no espaço ficcional à frente desse personagem e não enquadrado na vinheta, haveria uma plateia, de onde provém a fala na segunda vinheta.

A articulação entre o título da série e as imagens remete a um gênero cada vez mais presente na vida contemporânea: as palestras sobre diferentes temas que proliferam em convenções de empresas, comemorações institucionais e eventos em geral. No entanto, como se trata de um gênero, a tira cômica, que tem o humor como um aspecto constitutivo, há uma série de quebra de expectativas com relação a um funcionamento bona fide. A presença dos elementos gráficos que remetem ao gênero palestra se configura como traços de uma estratégia de subversão a partir de um gênero-fonte (cf. CHARAUDEAU e MAINGUENEAU, 2004, p. 94), parodiado para ser desqualificado, como veremos na análise. Desse modo, o jogo enunciativo paródico é um dos procedimentos utilizados pelo emissor para o ato humorístico, porém não é o único, também está presente a ironia. Como veremos, embora muito econômica no uso dos recursos verbais e visuais, essa tira encerra um complexo jogo de procedimentos e efeitos de sentidos.

A primeira fala é do locutor-personagem Malvadinho: - Sete gols da Alemanha. Como enunciado, circunscreve um referencial temático para a "palestra", o que já é um elemento inusitado: uma palestra para falar do resultado de um jogo? Em seguida, dá voz

\footnotetext{
${ }^{88}$ Em entrevista ao site $A$ arca, perguntado sobre o que seriam os personagens, Dahmer se esquivou de explicar o que são. Respondeu que os Malvados foram chamados de "flores" ou "girassóis" pela imprensa, mais precisamente por Sérgio Maggi, do jornal $O$ Globo. Acrescentou ainda que preferia deixar essas especulações sobre o que é seu trabalho para os jornalistas, "estes mestres na arte de inventar definições: "quadrado mágico", "geração internet"...Eles precisam disto para vender jornais". Entrevista disponível em $\langle$ http://www.a-arca.com.br/2006/10/entrevista-exclusiva-andre-dahmer-o-pai-dos-malvados/〉, acesso em 04/01/2017.
} 
a um Enunciador (E1) que expressa um ponto de vista a respeito: Que número poderia ser pior para o Brasil? Os elementos não verbais, a quase falta de expressividade do rosto do personagem e todo o quadro construído pelo cenário, conferem uma vocalidade (cf. MAINGUENEAU, 2008b) de gravidade ao enunciado. Porém, em lugar de instaurar a cenografia enunciativa de uma palestra - em conformidade com os aspectos gráficos e o título da série -, esse enunciado remete às falas que circulam nos programas de rádio e televisão relacionados ao mundo esportivo, tais como as mesas-redondas pré e pós-jogos. Nesses programas, confere-se importância e relevância aos acontecimentos dos eventos esportivos, especialmente resultados de jogos, comparáveis às notícias que impactam o dia-a-dia do cidadão comum. É o que temos expresso na interrogação retórica do enunciador. Embora o locutor-personagem estivesse falando de futebol, isso se apaga na materialidade da pergunta, na qual se interroga se haveria número pior para $o$ Brasil e não para a seleção brasileira de futebol. Apesar de naturalizada a assimilação entre o nome do país e a seleção, nesse caso intencionalmente as duas possibilidades estão presentes para proporcionar o jogo enunciativo que se desenrolará na sequência.

$\mathrm{Na}$ segunda vinheta, a pergunta retórica é respondida. O enunciado está em um balão-fala zero cujo apêndice indica que provém da plateia implícita na cena e é um dado da realidade social brasileira: - Cinquenta mil assassinatos por ano? ${ }^{89}$. Nessa passagem da primeira para a segunda vinheta, traz-se para o plano ficcional da tira um enunciador cujo ponto de vista (E2) se contrapõe ao do E1. O ponto de vista do E2 corresponde ao que identificamos como o do bom senso racional, a saber: a violência que atinge a população é um fato relevante para o país, ou seja, o resultado de um jogo não é algo ruim para o Brasil como país e seus cidadãos, o número de assassinatos anuais, sim. No nível pragmático, um dado tão contundente usado em um debate confere ao argumento um valor de verdade irrefutável, que seria impossível negar. Por outro lado, é incongruente com a cenografia enunciativa instaurada na primeira vinheta, pois não teria cabida em programas sobre futebol, nos quais a atitude de um jogador ou de um árbitro durante uma partida recebem o mesmo tratamento de uma notícia do campo político ou econômico.

$\mathrm{Na}$ terceira vinheta, temos a virada para o jogo enunciativo irônico (cf. CHARAUDEAU, 2006) usado como procedimento para o humor nessa tira. Trata-se de uma fala aparentemente cortês que expressa um ponto de vista absurdo, em que o locutor-

\footnotetext{
${ }^{89}$ Segundo informações do Atlas da Violência, relatório elaborado pelo Instituto de Pesquisa Econômica Aplicada (Ipea) em parceria com a ONG Fórum Brasileiro de Segurança Pública, em 2015 houve 59.080 homicídios. Fonte: http://www1.folha.uol.com.br/cotidiano/2017/06/1890315-negro-e-jovem-sem-estudosao-maiores-vitimas-de-violencia-mostra-pesquisa.shtml (acesso em 01/06/217)
} 
personagem faz uso de uma fórmula de cortesia (Por favor) que poderia ser interpretada também como um pedido, uma solicitação, e de uma forma de tratamento de proximidade e afetividade (querido) para refutar o argumento do bom senso racional (50.000 assassinatos anuais é um número pior para o Brasil que os 7 gols da Alemanha na Copa), baseando-se em um argumento ilógico (a realidade não tem lugar aqui). No plano ficcional da tira, o alvo da ironia, aquele que se procura desqualificar é o personagem da plateia como personagem-alocutário. Como afirmamos, seu argumento não condiz com os posicionamentos válidos na cenografia enunciativa instaurada pelo ponto de vista expresso por E1 na primeira vinheta, pois no espaço discursivo da mídia esportiva futebolística não se contrasta o resultado ruim de um jogo com dados da realidade social.

Entretanto, ao desqualificar o ponto de vista do E2 da segunda vinheta mediante uma negação, o E3 acaba conferindo-lhe, paradoxalmente, um status mais qualificado. A partir dessa negação (Realidade, não!), é possível depreender que: (a) o futebol/a derrota/ a Copa não são realidade; (b) sim, a realidade tem números piores para o Brasil que o resultado do jogo. Considerando os pressupostos que se instauram em um debate, o E3 dá razão ao E2. Desta sorte, seu enunciado encerra um sentido contrário ao que está dito, um dos aspectos tradicionalmente abordados nas definições de ironia.

Há, portanto, um jogo de sucessivas incongruências entre a cenografia instaurada pelos enunciados, o gênero-fonte evocado pelos elementos não verbais e o título que culminarão num ato de humor irônico, para o qual interpretamos como efeito possível a conivência crítica (cf. CHARAUDEAU, 2006). Contrapõe-se a realidade social do Brasil como argumento contra o discurso midiático, e hegemônico naquele momento, a respeito do impacto da derrota. Como pudemos verificar, o quadrinista, como emissor do ato humorístico, lança mão de vários procedimentos discursivos-enunciativos na produção do humor e, justamente por isso, entendemos que em lugar de um alvo, há vários. Assim, temos como procedimentos o jogo paródico e irônico e vemos como alvos, expostos e questionados: (a) o gênero palestra - sua temática, sua eficácia; (b) os protagonistas desse gênero, os palestrantes - desdenham de argumentos, ofendem a plateia e (c) os programas de futebol, seus participantes e espectadores - por às vezes conferirem preeminência desmedida ao esporte e ignorarem os problemas da realidade social brasileira.

$\mathrm{Na}$ tensão entre as duas cenografias (palestra X programa sobre futebol) retratada na tira emergem dois posicionamentos sobre o futebol, ou mais precisamente sobre a Copa do Mundo, situados em polos contrários. Aquele em que a Copa é vista como uma 
forma de mascarar a realidade, alienante e outro em que os resultados do desempenho da seleção do país na Copa são igualados à imagem do país, à nação. Ambos os posicionamentos marcam os discursos sobre o futebol no Brasil e serão retomados pois estão presentes também na próxima tira que abordamos.

\subsubsection{Depryzinha - Motivos para deprimir-se}

Ironia e sarcasmo são duas noções que guardam muita proximidade, sendo às vezes confundidas. O senso comum distingue as duas imputando mais agressividade, mordacidade, à segunda. Como vimos no capítulo dois, Charaudeau (2006) aponta que mesmo fazendo parte dos procedimentos enunciativos em que podemos observar uma dissociação entre o que o Eu-locutor pensa e o que o Eu-enunciador diz, esses dois conceitos se distinguem porque na ironia o pensado e o dito são polarizados de forma diferente - um negativa e o outro positivamente, enquanto no sarcasmo, ambos são negativamente polarizados, com uma hiperbolização do aspecto negativo expresso pelo dito. O autor reforça ainda a diferença de efeito sobre o interlocutor. Segundo ele, o sarcasmo rompe completamente com a cortesia, pois com ele coloca-se o interlocutor numa posição desagradável. Essa caracterização de Charaudeau pode ser observada na tira que ora enfocaremos.

Trata-se da tira Amely, de autoria de Pryscila Vieira e faz parte do projeto Quadrinhas, já citado neste trabalho. Foi publicada em 14/07/2014, na segunda-feira seguinte à finalização da Copa de 2014 e está reproduzida na figura 43. 


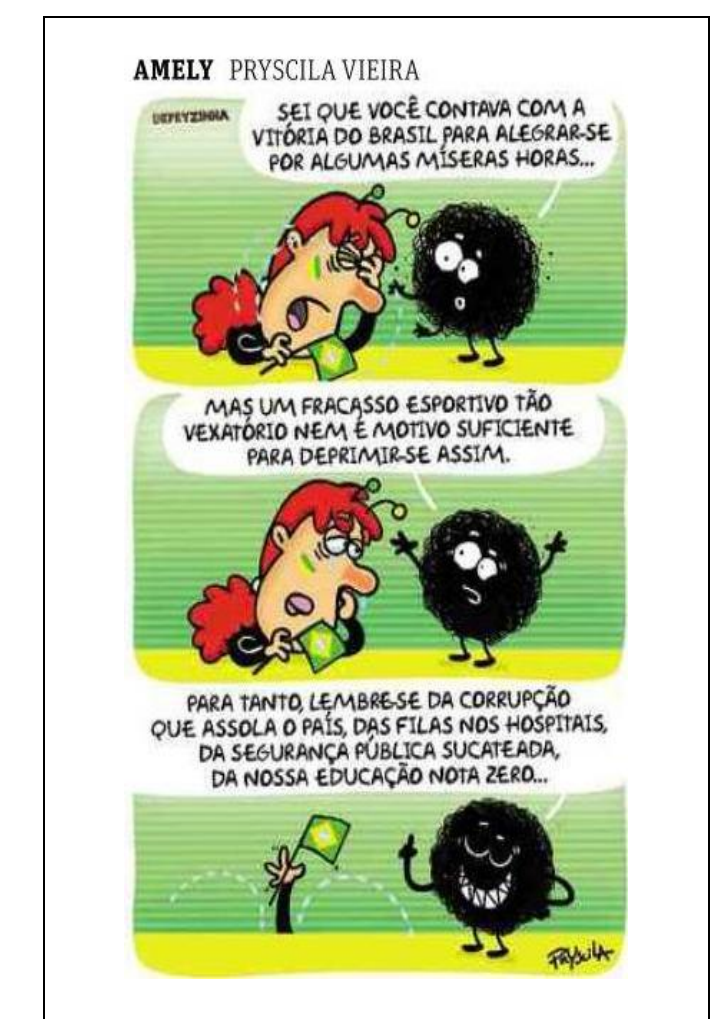

Figura 43 - Depryzinha - Motivos para deprimirse Fonte: Folha de S. Paulo de 14/07/2014

Embora tenha saído sob o título Amely ${ }^{90}$, essa narrativa é protagonizada por outras duas personagens: Deprê, uma espécie de borrão preto animado que, como o próprio nome indica, é uma depressão, e Depryzinha, uma jovem ruiva que interage com a deprê ora como uma amiga, ora como um animal de estimação.

$\mathrm{Na}$ primeira vinheta vemos a personagem Depryzinha chorando, com uma bandeira do Brasil na mão, e a personagem Deprê numa atitude corporal em que parece consolá-la. Há outros elementos verde-amarelos que, além de ajudar na composição do cenário funcionam também para circunscrever o referencial temático: a tira se refere à derrota do Brasil.

Ao longo da narrativa que se desenrola no plano ficcional, somente a personagem Deprê fala. Em sua primeira intervenção, instaura uma cenografia que é congruente com o cenário não verbal: uma conversa entre duas pessoas, uma tratando de consolar a outra que chora. Nos enunciados contidos nos dois primeiros balões-fala da personagem que consola, no entanto, pouco a pouco vão surgindo marcas que mostram que se trata de um pseudo-consolo pois em suas falas há uma mescla de vozes que vão fazendo emergir o sarcasmo. A personagem-locutor começa mostrando solidariedade (Sei que você contava

\footnotetext{
${ }^{90}$ A personagem que dá nome à tira - Amely - é uma boneca inflável. Para detalhes sobre a(o)s autore(a)s e o(a)s persongens, consultar o Apêndice.
} 
com a vitória do Brasil para alegrar-se...), mas em seguida emerge a voz de um enunciador (E1) no adjetivo míseras para qualificar horas, que rebaixa a finalidade que a vitória do Brasil teria para a personagem-alocutária. O mesmo se dá no enunciado do segundo balão-fala no qual aparentemente Deprê busca tirar importância do evento, mas o que faz é desqualificar completamente o motivo (a derrota) como justificativa para deprimir-se e ao fazê-lo intensifica seus aspectos negativos. Mediante a voz do enunciador, a derrota é nominalizada como fracasso, por sua vez qualificado como tão vexatório. Tanto o substantivo fracasso, como os adjetivos míseras e vexatório figurariam num grau superlativo em sequências do mesmo campo semântico. Verificamos, portanto, a hiperbolização dos aspectos negativos apontada por Charaudeau (2006) como um recurso característicos em atos de humor que envolvem procedimentos enunciativos sarcásticos. Além disso, o enunciado vincula-se interdiscursivamente ao paradigma instituído pela mídia ao noticiar a derrota e que mencionamos no item 2.3 anterior.

O conteúdo verbo-visual da última vinheta traz a virada para o humor com a explicitação do sarcasmo. No nível pragmático, há uma quebra total de expectativa quanto ao esperado na situação representada no espaço ficcional. O esperado seria que já que a derrota não é motivo para deprimir-se assim - a personagem Deprê apresentasse argumentos que tirassem o foco do fato circunscrevendo-o ao âmbito do que não é importante. No entanto, o que faz é, com uma expressão facial de contentamento, apresentar motivos suficientes para Depryzinha deprimir-se assim: uma enumeração dos problemas crônicos do Brasil e que envolvem corrupção, saúde, educação, segurança, ou seja, as mesmas pautas presentes nas manifestações que eclodiram a partir de 2013 e que já destacamos anteriormente.

No plano ficcional, há claramente uma intenção da personagem-locutor em agredir a personagem-alocutária, o alvo do sarcasmo, fazendo-a ficar mais deprimida do que estava. Temos aqui outra característica apontada por Charaudeau (2011) sobre o sarcasmo ao comentar que com ele se rompem as regras de cortesia pois "se diz o que não deve ser dito”. Não se consola uma pessoa deprimida dizendo coisas negativas que vão deixá-la ainda mais deprimida.

Se no plano ficcional o alvo do sarcasmo é a personagem, na sua exterioridade vemos como alvo simbólico desse ato de humor o comportamento de conferir à derrota da seleção brasileira na Copa impacto comparável aos problemas sociais que afetam o país. Além disso, também está em foco o desempenho da seleção brasileira. Entendemos que o efeito possível com o leitor é o da conivência crítica, o emissor do ato de humor coloca 
em questionamento esses alvos, tornando-os objetos de controvérsia e, por conseguinte, de crítica.

Igualmente nos parece que - à semelhança da tira de André Dahmer (figura 42) temos interdiscursivamente em funcionamento polêmico dois posicionamentos a respeito do papel do futebol no Brasil. Em um deles se reifica o país na seleção que o representa na Copa e, assim, iguala-se o resultado dos jogos às questões que afetam seus habitantes enquanto cidadãos. No outro, o futebol é visto como um instrumento para a felicidade ilusória da população e desmobilizador da consciência crítica a respeito dos problemas que afetam a sociedade, ou seja, como o "ópio do povo" que Marx usou para qualificar a religião. Lopes (2014) identifica nesse segundo posicionamento procedimentos pelos quais o futebol é desvalorizado, colocado abaixo de outras práticas sociais, que seriam vistas como mais legítimas. Além disso, esses procedimentos - discursos, diríamos nós classificam socialmente seus defensores pois os colocam intelectualmente acima daqueles que gostam de futebol. Nas palavras do autor:

Longe de apenas diferenciar de forma neutra, essa oposição simbólica (entre um "nós-iluminados" e um "eles-alienados") criada pela tese do "ópio do povo" discrimina e hierarquiza socialmente. Distingue, portanto. Afinal, eleva seus defensores ao "mundo das ideias" enquanto imprime nos amantes do futebol a marca da ignorância. Por conseguinte, desacredita os últimos como sujeitos racionais, capazes de pensar criticamente, ao mesmo tempo que valida a superioridade intelectual dos primeiros, conferindo-lhes autoridade pedagógica. (op. cit. p. 142)

Nesse sentido, ainda segundo o autor, servem para legitimar relações de dominação - principalmente de classe, pois ao futebol como prática social subalterna estariam opostas aquelas reconhecidas como legítimas, pois elevadas, dos setores mais intelectualizados da burguesia (idem). Embora concordemos com o autor quanto à posição de superioridade em que se colocam aqueles que vêm o futebol como felicidade ilusória, não compartilhamos de sua visão quanto à origem dessa visão, ou seja, o fato de provirem de segmentos da burguesia. Ressaltando que falamos de um lugar não especializado, entendemos que os diferentes posicionamentos relativos ao futebol no Brasil têm uma configuração mais complexa, inclusive quanto à classificação dos atores sociais envolvidos, que talvez a contraposição entre classe trabalhadora e burguesia, ou setores intelectualizados da burguesia, não dê conta.

Quanto ao primeiro posicionamento, destacamos com Guedes (2014) que a importância do futebol no Brasil pode ser aquilatada pelo fato de ser o único esporte em 
que as derrotas são tão - ou mais, diríamos - significativas que as vitórias. A autora chega a afirmar que isso é uma prova de que o futebol é o único esporte nacional. Em suas palavras:

através do futebol, pelo menos desde 1950, quando uma derrota inesperada fundou a coletividade irmanada, o Brasil e os brasileiros são debatidos e representados nos desempenhos do selecionado brasileiro. $\mathrm{E}$ se, em cada vitória, celebra-se a capacidade de união dos brasileiros, muitas vezes expressa nas representações coletivas sobre "miscigenação", em cada derrota são debatidas as questões que dividem e mobilizam a sociedade brasileira naquele momento.

Como pudemos verificar especialmente nas duas últimas produções abordadas, também em 2014 a derrota do Brasil assumiu proporções que extrapolaram o campo esportivo, o que foi favorecido pela alta temperatura do ambiente social e político em que o país se encontrava naquele momento. E justamente esse ponto - o debate das questões sociológicas a partir do resultado da Copa - é tematizado na tira que analisamos a seguir.

\subsubsection{O pintinho - Prova-surpresa}

A tira $O$ Pintinho reproduzida na figura 44 é outra das produções de nosso corpus cuja autoria pertence a Alexandra Morais, quadrinista que também publicava às segundasfeiras na Folha de S. Paulo dentro do projeto Quadrinhas. 


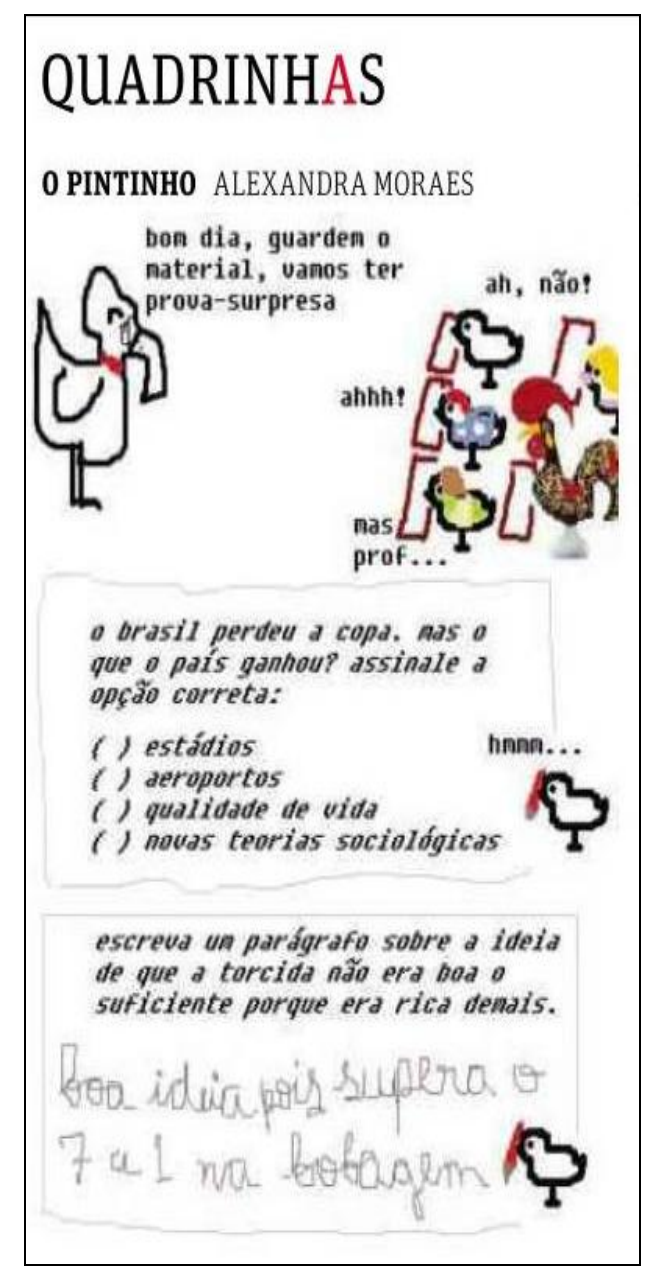

Figura 44 - O pintinho - Prova-surpresa Fonte: Folha de S. Paulo 14/07/2014

Trata-se de uma tira de orientação vertical e não há divisão entre as diferentes cenas que compõem a narrativa. A primeira cena reproduz uma sala de aula. Nela vemos uma ave, possivelmente uma pata, como professora à frente de quatro pintinhos e uma imagem do galo de Barcelos alinhados em duas fileiras de carteiras. O traço algo naïf que a autora obtém usando o Paintbrush, o inusitado de ver aves no papel de professora e alunos, a fotografia de um souvenir turístico em meio ao cenário, conferem um aspecto lúdico à tira, parece destinada ao público infantil. A cenografia que instaura o enunciado da personagem-locutor é congruente com a cena construída pelos aspectos não verbais. Como professora, anuncia que terão uma prova surpresa.

$\mathrm{Na}$ transição para a cena seguintes opera-se um corte, o leitor, como alocutário, se vê frente a uma nova cenografia, uma questão de múltipla escolha. Deverá deduzir que faz parte da prova que foi anunciada pela pata-professora na primeira vinheta. Graficamente, a questão da prova é representada desproporcionalmente grande em comparação com o aluno que a responde, o pintinho, que vemos no canto inferior dessa 
vinheta e da seguinte, com um lápis no bico. O enunciado da questão joga com o valor semântico de perder e ganhar. Nele, se parte de uma constatação "O Brasil perdeu a Copa", e se questiona "Mas o que o país ganhou?" Nas alternativas, mesclam-se obras de infraestrutura, o conceito abstrato de "qualidade de vida" e "novas teorias sociológicas". O pintinho está hesitante e todas as alternativas permanecem em branco.

A última cena traz a mesma cenografia, uma questão da prova, dessa vez dissertativa. A resposta do pintinho é dada em letra cursiva. Como vemos, os elementos gráficos contêm informações sobre as diferentes vozes que intervêm nas cenas e as cenografias que instituem.

Como recursos para o humor temos um procedimento discursivo paródico, com o reinvestimento de um gênero (a prova escolar) que é subvertido. A imitação desqualifica a autoridade do gênero fonte (cf. CHARAUDEAU e MAINGUENEAU, 2004, p. 94). Primeiramente por ser reinvestida dentro de um outro gênero que tem o humor como característica constitutiva. Em segundo lugar, pelo caráter absurdo das questões e das alternativas.

Além do jogo paródico, temos também o jogo irônico usado para o funcionamento do humor nessa tira e está presente na última vinheta. Há uma dissociação entre o que o personagem-locutor diz e o sentido do que diz. Ele atribui uma avaliação positiva (Boa ideia) justificada por um argumento absurdo (supera o 7 a 1 na bobagem), construindo um sentido que é na verdade negativo. $\mathrm{O}$ alvo do ato de humor é algo externo ao universo ficcional. Em lugar de alguém, nos parece que temos algo, que identificamos como as discussões que procuravam razões sociológicas para explicar os acontecimentos da Copa de 2014. Está presente interdiscursivamente nos enunciados o posicionamento segundo o qual a Copa se justificava porque seria boa para o Brasil, pois, entre outras coisas, traria um legado de obras e melhorias para a população, redundando numa melhor "qualidade de vida" e ao qual já nos referimos.

Diferentemente das outras tiras analisadas, parece-nos que o foco escolhido para tematizar a derrota do Brasil é mais distanciado. Está presente a conivência crítica, como efeito possível de sentido, na contestação aos argumentos a favor da Copa e às explicações "sociológicas" que circularam, mas o impacto emocional causado pela derrota não está em causa.

Nessas três produções (figuras 42, 43 e 44) em que identificamos como efeito possível para o humor a conivência crítica, parece-nos que podemos também identificar nos emissores dos atos de humor um ethos de superioridade intelectual e distanciamento 
com relação aos eventos da Copa de 2014, pois para criticar é preciso olhar de outra perspectiva, observar desapaixonadamente. Na medida em que esse ato de humor precisa ser interpretado pelo leitor - seu destinatário -, o emissor busca também partilhar dessa superioridade. Como já afirmado por outros autores, o humor é uma piscadela do emissor para o destinatário. Ao entender o humor da tira, o leitor-destinatário estabelece uma espécie de relação de cumplicidade com o emissor.

A última produção a ser abordada sobre a derrota do Brasil é de autoria de Allan Sieber, é um exemplar da tira Bifaland, a Cidade Maldita e está reproduzida na figura 45.

\subsubsection{Bifaland, a Cidade Maldita - Os piores da Polca 2014}

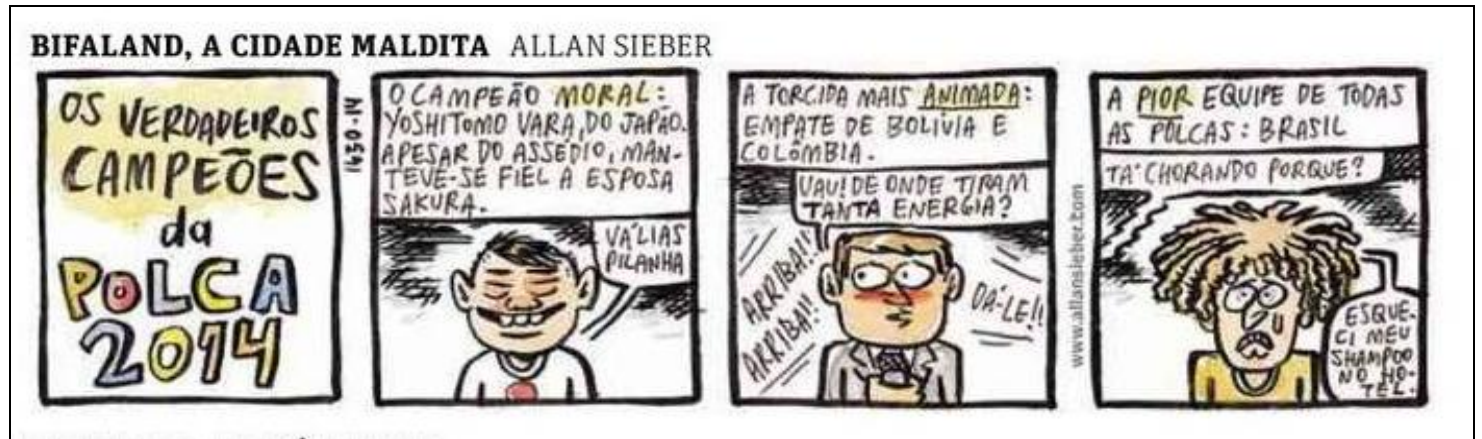

Figura 45 - Bifaland - Campeões da Polca 2014 - Fonte: Folha de S. Paulo de 15/07/2014

Essa produção de Allan Sieber é uma tira fixa protagonizada por diferentes personagens, mas alguns podem aparecer com certa periodicidade. As narrativas de Bifaland, a Cidade Maldita são sempre marcadas pelo sarcasmo, pela iconoclastia, pela contestação - mediante a subversão - de valores tradicionais. Entre as tiras que tematizam o desempenho do Brasil, essa é a única em que, além dos procedimentos discursivos, há também o uso dos procedimentos classificados como linguísticos por Charaudeau (2006) como recurso para a criação do humor. Esses procedimentos estão a serviço de outra estratégia, a paródia depreciativa com nomes, bastante presente nas produções do autor. O título da tira é formado pelo nome bifa - sinônimo de tabefe - e land - terra, em inglês - usado como sufixo para formar nomes de lugares. Uma das possibilidades de interpretação é que o nome reinvestido na subversão (cf. CHARAUDEAU \& MAINGUENEAU, 2008) seja Disneyland, o "mundo maravilhoso de Disney" como ícone do mundo absolutamente perfeito e feliz que o poder do capital pode criar artificialmente. 
A tira tem quatro vinhetas, com bordas muito bem delimitadas. A primeira delas contém um título e em cada uma das três seguintes encontramos imagens de três homens diferentes, em um enquadramento de plano americano. A cenografia instaurada pelo título remete ao anúncio dos vencedores de uma competição ou concurso. A narrativa é o próprio anúncio que vai se desenvolvendo como se fossem três cenas de um quadro de programa de televisão, as bordas das vinhetas reforçam a idéia da mudança de quadros. As imagens dos personagens seriam cenas filmadas anteriormente, projetadas com a voz do narrador-locutor em off, que aparece como legenda, na parte superior das vinhetas. Como veremos, na tira estão presentes vários estereótipos no sentido mais comumente atribuído ao termo pelo senso comum, ou seja, aqueles que envolvem preconceitos.

Na primeira vinheta, temos o título do quadro: “Os verdadeiros campeões da Polca 2014”. Ao longo do período em que se realizou a Copa de 2014, Sieber publicou na Folha de S. Paulo algumas tiras tematizando o evento nas quais usava o termo Polca para referir-se a ele. Assim, verificamos também aqui uma reinversão com subversão que se dá por meio da semelhança fonética entre Copa e Polca. Esse substantivo pode referir-se a: (a) gênero de música de dança originário da Boêmia que chegou ao Brasil em meados do século $\mathrm{XIX}^{91}$ e alcançou imensa popularidade no país; (b) à forma como alguns falantes do português pronunciam porca, tanto referindo-se à rosca do parafuso como à fêmea do porco. Qualquer que possa ser a compreensão, parece-nos que o rebaixamento com relação a um megaevento esportivo internacional é evidente.

Essa mesma estratégia é usada para os nomes que aparecem na fala do narrador na segunda vinheta: Yoshitomo Vara $^{92}$ e Sakura. Quanto ao segundo, Sakura é uma marca conhecida de produtos alimentícios orientais no Brasil. Já no primeiro caso, o jogo se dá pelo cacófato que a junção do nome com o sobrenome possibilita, uma leitura que envolve o verbo tomar (Yoshitomo) e o substantivo vara. Ambos têm conotação sexual e o sentido resultante do cacófato lança suspeita sobre a fidelidade do personagem. Manteve-se fiel à esposa ou tomou vara (foi penetrado)? Como vemos, o resultado da zombaria é claramente homofóbico. No balão-fala do personagem (valias pilanha), outro

\footnotetext{
${ }^{91}$ No país o gênero ganhou contornos próprios. Nas execuções das peças, os músicos brasileiros thes acrescentavam os elementos afro-brasileiros do lundu o que tornou o ritmo mais surpreendente e divertido. Informações obtidas com consulta ao verbete polca nos seguintes sites especializados: $<$ http://www.concertino.com.br > e <http://dicionariompb.com.br. $>$. Acesso em 10/06/2017.

${ }^{92}$ Yoshitomo Nara é um artista plástico japonês contemporâneo. Seu trabalho se insere dentro da pop-art e é conhecido sobretudo por pinturas de crianças e animais com expressões desafiadoras ou mesmo amedrontadoras. Apesar da grande proximidade fonética entre seu nome e o usado por Sieber, nos faltam elementos para concluir que o sentido simbólico associado ao artista estivesse sendo subvertido. Acreditamos que o jogo se dá somente pela possibilidade de duplo sentido que o nome encerra.
} 
estereótipo: a substituição da letra "r" pelo "l" tentando reproduzir o sotaque característico de alguns orientais ao falar português.

No plano ficcional da tira o alvo é o personagem, no plano dos efeitos de sentido simbólico, de nosso ponto de vista, esse personagem poderia ser assimilado à torcida japonesa. E por qual razão? Por um gesto nobre que tiveram durante a Copa. Em pelo menos duas ocasiões a imprensa noticiou que após a partida os torcedores japoneses recolheram o lixo que produziram ${ }^{93}$, o gesto de civilidade poderia ser interpretado como um alto valor moral, do qual o ato de humor acaba escarnecendo.

O título "campeão moral", por sua vez, encerra mais complexidade. Além do sentido mais superficial já comentado, ou seja, de campeão com altos valores morais, no campo discursivo do futebol a expressão está inserida na historicidade da relação entre futebol, Argentina e Brasil. Nossa pesquisa tentando recuperar a origem da expressão nos levou a que teria sido cunhada por Cláudio Coutinho, técnico da seleção brasileira que disputou a Copa de 1978, ganha pela Argentina e realizada naquele país. O Brasil ficou com o terceiro lugar, apesar de ter feito uma boa campanha, não ter perdido nenhum jogo e ter sido a única seleção invicta daquela edição. Guterman (2014, pp. 198-200), ao abordar a campanha do Brasil na Copa de 78, nos conta que a Argentina conquistou a vaga para a partida final contra a Holanda ganhando do Peru - já desclassificado - por 6 a 0 , um resultado que levantou muitas suspeitas. O Brasil acusou o Peru de ter entregue o jogo e chegou inclusive a protestar junto à Fifa, sem resultado. Em artigo publicado em um número da revista Placar de 1983, cinco anos depois portanto, o jornalista Augusto Nunes comenta que o curioso prêmio de consolação fora inventado por Coutinho após a Copa, que dissera na ocasião "fomos os campeões morais", e que vinha sendo conferido com muita frequência à seleção brasileira. É muito difícil afirmar que Coutinho tenha sido realmente o autor da expressão, porém as evidências apontam que a partir de sua fala a expressão inseriu-se no campo discursivo do futebol no Brasil. A analogia entre o caso do Brasil em 1978 e o Japão em 2014 seria o fato de a seleção desse país ter sido eliminada ainda na fase de Grupos. Não ganharam a Copa, mas seriam campeões morais pelo gesto de civilidade e sobre isso recai o escárnio do ato de humor.

$\mathrm{Na}$ terceira vinheta, verificamos outros estereótipos que envolvem preconceitos. Para relacionar torcida mais animada com Bolívia e Colômbia e tanta energia o leitor

\footnotetext{
${ }^{93}$ Conforme reportagem de autoria de Marcel Merguizo disponível em http://www1.folha.uol.com.br/esporte/folhanacopa/2014/06/1473262-no-japao-sempre-recolhemos-o-lixodiz-japones-apos-jogo-em-natal.shtml. Acesso em 20/06/2017.
} 
deverá desvelar alguns implícitos: o cultivo de coca nesses países e o fato de cocaína ser uma droga com efeitos estimulantes. O enunciado interrogativo como comentário aos gritos em espanhol que se veem ao fundo instaura uma desconfiança, uma espécie de enigma para o leitor como destinatário do ato de humor. O quadrinista, como emissor, faz uso de algumas marcas gráficas que não podem ser ignoradas como informação paratextual: a palavra animada, além de destacada em amarelo, está grifada. No balãofala do personagem-locutor a palavra tanta também está em negrito. $\mathrm{O}$ alvo do ato de humor são os países citados, Colômbia e Bolívia, sendo que este último sequer esteve entre os países que participaram da Copa.

Embora cada uma das vinhetas encerre um sentido completo e não haja exatamente entre elas uma relação de dependência na sequência narrativa, é possível constatar que há uma gradação na premiação, que começa com o título de campeão moral e termina com o de "a pior equipe de todas as polcas", o prêmio superlativo negativo, outorgado para o Brasil. O cabelo do personagem retratado e o choro permitem identificar que se refere ao jogador David Luiz, o alvo mais evidente do procedimento sarcástico. $\mathrm{Na}$ partida contra a Alemanha, o jogador atuou como capitão e após a derrota deixou o campo aos prantos. Em meio a lágrimas, declarou:

só queria poder dar uma alegria ao meu povo. Para minha gente que sofre tanto com tantas coisas. Não conseguimos, infelizmente. Desculpa a todos, a todos os brasileiros. Só queria ver meu povo sorrindo. Todo mundo sabe o quanto era importante para eu ver o Brasil inteiro feliz pelo menos por causa do futebol. Eles foram melhores, se prepararam melhor, melhor jogo. ${ }^{94}$

$\mathrm{Na}$ tira, o personagem chora por haver esquecido seu xampu no hotel. O rebaixamento evidente envolve vários implícitos e representações simbólicas, entre os quais citamos o caráter prosaico do motivo, o fato de ser um gesto de vaidade numa sociedade em que isso é considerado ainda pouco masculino, a masculinidade estar associada a espírito de luta, garra, justamente o contrário da apatia e desorientação que a seleção brasileira mostrou em campo. Ademais, nos atuais tempos em que os jogadores se converteram em celebridades e em que é preciso dar motivo para a exposição midiática, os cabelos dos jogadores da seleção - o corte, a cor, o estilo - se transformaram em assunto para jornais e revistas ${ }^{95}$. Da mesma forma que no caso da segunda vinheta,

\footnotetext{
${ }^{94}$ Disponível em <https://copadomundo.uol.com.br/noticias/redacao/2014/07/08/aos-prantos-david-luizpede-desculpas-e-diz-so-queria-ver-o-povo-sorrir.htm>. Acesso em 10.06. 2017.

${ }_{95}$ Em contexto completamente diferente, o cabelo também já foi motivo de polêmica na Argentina. Em 1996, o então técnico Daniel Passarella impôs como norma que os jogadores não tivessem cabelo comprido. Caniggia e Redondo se negaram a cortar os cabelos e não foram convocados. A polêmica enfrentou dois posicionamentos antagônicos: a contestação e o disciplinamento.
} 
parece-nos que também pode haver aqui uma assimilação entre o jogador diretamente convertido em alvo do escárnio e a quase totalidade dos jogadores, ou especialmente aqueles cujo cabelo passa a ser uma ferramenta a ser usada na relação com a mídia.

Identificar os efeitos possíveis do humor para essa tira é uma operação complexa, posto que cada vinheta encerra um ato humorístico diferente, com procedimentos e alvos diferentes. Charaudeau (2006), ao propor suas categorias para analisar o humor a partir de uma perspectiva discursiva alertou para o perigo que o ato de categorizar encerra. Ele próprio reconhece o caráter reducionista que o procedimento implica. Como saída, esclarece que sua proposta era propor categorias operatórias e não com caráter de essencialidade. Nesse sentido, quanto aos efeitos possíveis do humor dessa produção, vemos o que o autor classifica como de conivência cínica, muito mais agressiva que a conivência crítica e cujo objetivo é atacar valores sociais universais. Igualmente vemos a conivência de derrisão, que desqualifica o alvo, colocando-o como vítima do ato de humor, porque o emissor o vê como supervalorizado. Por fim, na última vinheta vemos também a conivência crítica como efeito possível. Embora haja uma forte desqualificação e rebaixamento do alvo, ao ridicularizar o jogador pela questão do cabelo está implícita uma crítica à excessiva exposição midiática que alguns jogadores perseguem.

Atribuir características ao ethos que se constrói para o emissor nessa tira é igualmente complexo. Tal como nas produções anteriores, nos parece que envolve também uma superioridade, mas é uma superioridade que tem um modus operandi mais agressivo, pelo sarcasmo, que aparentemente investe contra tudo e contra todos. Em lugar da piscadela anteriormente referida, podemos compará-la a a uma careta debochada.

Antes de encerrarmos a análise dessa produção, gostaríamos de retomar a expresão "campeões morais". Durante nossa pesquisa a respeito dela, algumas informações se relevaram e nos parece oportuno um pequeno parêntese para sua exposição. Encontramos a expressão não só em português na tira de Allan Sieber, como também em espanhol em três tiras de Clemente, publicadas por ocasião das Copas de 1994, 1998 e 2002. Nessas tiras, a expressão desempenhava um papel importante como recurso para lograr o humor, elas estão reproduzidas em sequência cronológica nas figuras 46, 47 e 48. 


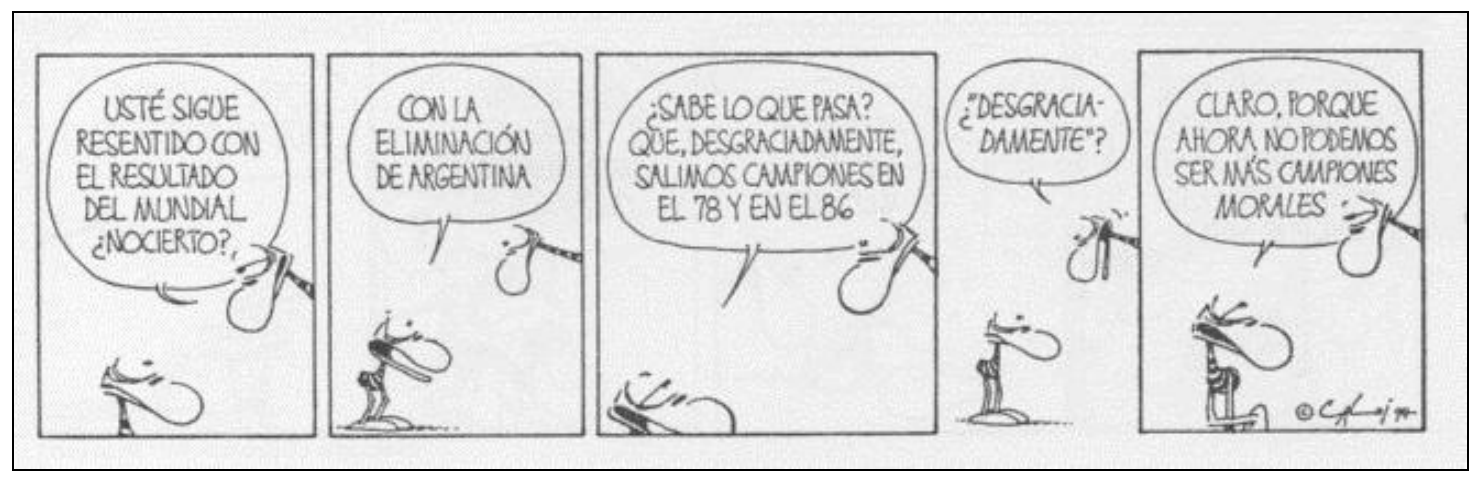

Figura 46 - Clemente - Campiones Morales 1994 - Fonte: Caloi (2014)

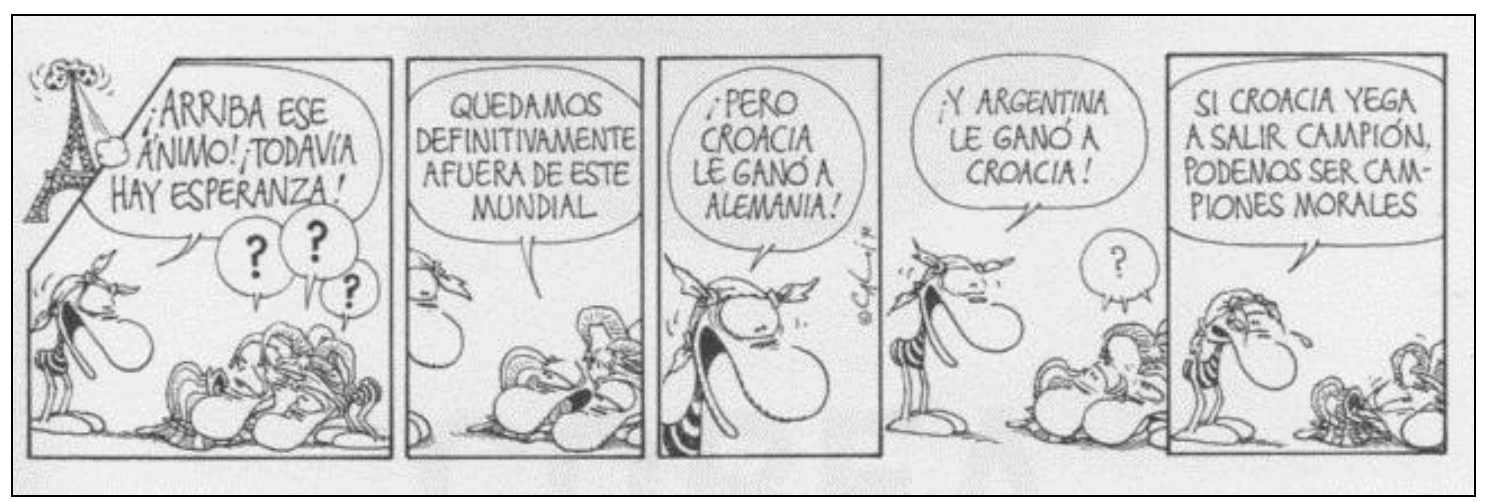

Figura 47 - Clemente - Campiones Morales 1998 - Fonte: Caloi (2014)

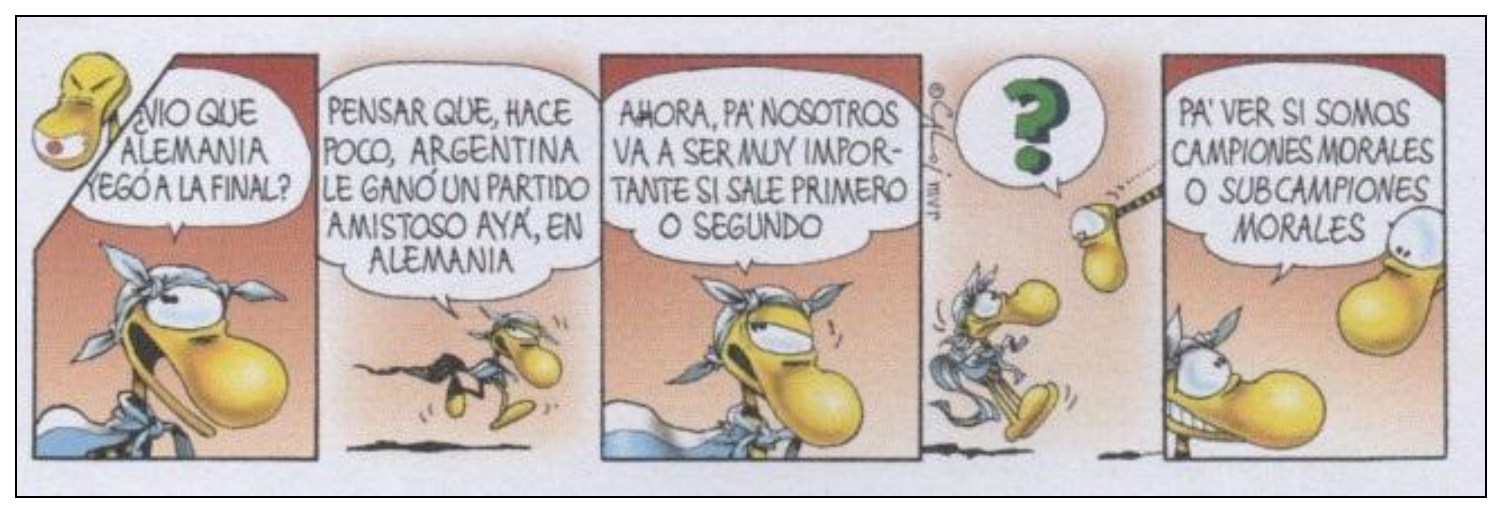

Figura 48 - Clemente - Campiones Morales 2002 - Fonte: Caloi (2014)

Nos três casos, sua publicação se deu em ocasiões em que a seleção argentina havia sido eliminada e, como prêmio de consolação, o personagem Clemente elabora um raciocínio absurdo para concluir que o selecionado do país merecia o título de campiones morales. Ao encontrá-las, nossa hipótese inicial foi de que se tratava de uma subversão que tinha como alvo a declaração de Coutinho em 1978, no entanto descobrimos que na Argentina a expressão já era usada no contexto do futebol. O uso documentado mais 
antigo a que chegamos é que foi usada pelo presidente de facto Juan Carlos Onganía ${ }^{96}$ ao receber de volta a seleção argentina de futebol na volta da Copa de 1966. A seleção fora eliminada do campeonato mundial em uma partida contra a Inglaterra, em resultado duvidoso que envolvia a lisura dos procedimentos do árbitro durante o jogo. Alabarces (2002, p.92) em um fragmento de sua análise sobre o acontecimento, comenta que (grifos conforme o original) "la excursión inglesa domina como marca imaginaria el resto de la década y el comienzo de la siguiente: los campeones morales seguirán cosechando fracasos a nivel de selecciones".

De fato, a Argentina só ganhará seu primeiro campeonato mundial em 1978, na vigência de um dos mais cruéis regimes de exceção de que se tem notícia. Como se sabe, o título foi usado politicamente de diferentes formas pela ditadura militar argentina para produzir sentidos que serviam a seus propósitos, tais como patriotismo e superioridade frente aos "inimigos". Também em Alabarces (2002, p. 121) encontramos documentado um uso da expressão que é preciso mencionar. Conforme o autor, no filme La fiesta de todos sobre o Mundial de 1978, dirigido por Sergio Renán e lançado em 1979, o humorista Luis Landriscina, que faz as vezes de locutor no filme, comenta sobre a conquista do campeonato argentino: Era inevitable. Nuestra alegría significaba la tristeza de los brasileros. Y bueno. En otros tiempos, ellos festejaban como si fueran carnavales sus victorias, mientras nosotros nos conformábamos con ser campeones morales.

O enunciado de Landriscina pode ter sido uma resposta a Coutinho ou não, é bem difícil descobrir. Por outro lado, a partir do uso da expressão pelo técnico no Brasil, podemos dizer que ela estava marcada pela alteridade/rivalidade construída entre os dois países. Marca essa que o devenir terminou por apagar. Parodiando Voloshínov (1986), parece-nos que neste caso podemos dizer que a palavra é a arena da disputa futebolística. Igualmente a contraposição alegria-tristeza será uma constante nas narrativas sobre as derrotas e vitórias da seleção argentina, como veremos nas tiras que foram publicadas a esse respeito na página de humor do Clarín.

Para encerrar esta parte da análise, abordaremos outra tira de Caco Galhardo, publicada também em 15/07/2014 e reproduzida na figura 49.

\footnotetext{
${ }^{96}$ Militar argentino que chegou ao poder após um golpe de estado cívico-milar que depôs o presidente eleito Arturo Umbero Illia em 28 de junho de 1966. Ficou no poder até 8 de junho de 1970. A seleção argentina que disputou a Copa de 1966 deixou o país sob um presidente, eleito legalmente, e foi recebida por outro, alçado a essa condição por um golpe.
} 


\subsubsection{Daiquiri - Vaca-fria}

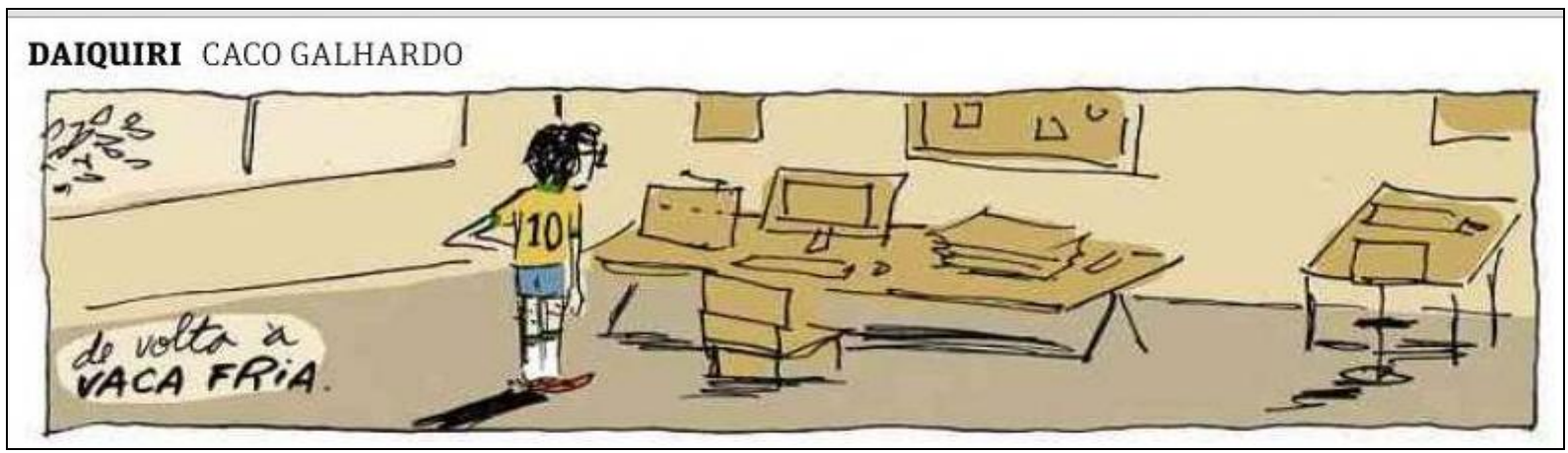

Figura 49 - Daquiri - Vaca-fria - Fonte: Folha de S. Paulo de 15/07/2014

Tal como a produção anterior do mesmo autor analisada no item 2.3.1.1 (figura 41), é também uma tira em uma só vinheta em que os elementos não verbais predominam. As informações referenciais para a construção do sentido igualmente estão no âmbito dos saberes partilhados pelos participantes da situação de comunicação em que ela se insere, que envolvem o fato de ser uma tira publicada em um jornal diário brasileiro, que seu autor vinha abordando a Copa, que o campeonato havia terminado etc. Como cenário, possivelmente uma representação do estúdio do quadrinista e dele próprio: uma sala com mesa, computador, uma prancheta, quadros de avisos na parede. Diante da mesa com o computador, um homem vestido com o uniforme da seleção brasileira, que na construção do sentido é não só a vestimenta do personagem da cena, como também um elemento que aponta para o tema da tira. Ele está parado com a mão na cintura como que avaliando a situação. No canto inferior esquerdo, o único elemento verbal: uma legenda com uma expressão popular "de volta à vaca fria" "97, que significa retomar assuntos ou afazeres interrompidos. Na articulação entre os elementos verbais e visuais, parece-nos possível interpretar que o personagem está não só avaliando a situação como relutando a começar o trabalho, já que, como a Copa terminou, é preciso retomar o interrompido.

A tira releva um dos aspectos simbólicos das Copas do Mundo em geral, que no contexto brasileiro acabam adquirindo certos sentidos particulares. As Copas, tal como as Olimpíadas e outros eventos esportivos, são mais que encontros competitivos de

\footnotetext{
${ }^{97}$ Conforme o Vocabulário Ortográfico da Língua Portuguesa, o termo deve ser grafado com hífen, como se trata de citação, mantivemos a forma original. A expressão seria uma versão do dito popular francês "Revenons à nos moutons" (Voltemos aos nossos carneiros), o qual, por sua vez, teria sido uma frase dita por um juiz a um advogado que divagava longamente em suas explanações durante um julgamento a respeito de carneiros roubados. O episódio faz relatado no texto anônimo "Farsa do advogado Pathelin", que data do século XV. Fonte 〈http://veja.abril.com.br/blog/sobre-palavras/como-esquentar-a-vaca-fria/> (acesso em 15/06/2017)
} 
jogadores (cf. BITENCOURT, 2009 e GUEDES, 2002 e 2006). O caráter cíclico, o cerimonial que se repete em cada uma de suas etapas, desde o sorteio das chaves até a premiação final, o fato de os atletas representarem seus países, confere a esses eventos um caráter de rito. No caso do Brasil, esse rito assume uma dimensão que impacta a vida cotidiana, afetando tanto os que nele se envolvem como os que o renegam. Guedes (2002, p.1) afirma que para os brasileiros as Copas constituem-se como verdadeiros rituais nacionais, ocasiões nas quais se celebra a "brasilidade, construção simbólica de unidade nacional". Embora não concordemos com a generalização da autora, pois de nosso ponto de vista caberia relativizar a homogeneização presente em "os brasileiros", é inegável que a Copa no Brasil adquire contornos próprios, haja vista que em jogos da seleção chegamos a ter aulas suspensas, expediente comercial reduzido etc. É justamente esse aspecto - o da suspensão do tempo cotidiano, a procrastinação de prazos e afazeres - que é abordado na tira. Na verdade, aborda-se o término dessa suspensão: encerrada a Copa, volta-se ao dia a dia, às tarefas, ao que poderíamos chamar de realidade de cada um.

Voltemo-nos agora para o único elemento verbal dessa tira. Trata-se de um exemplo do que Maingueneau (2008b, 2010) classificou como particitação ${ }^{98}$, as citações em que um locutor invoca um hiperenunciador, uma sabedoria "reconhecida pelos seus interlocutores, membros da mesma comunidade de experiência, da mesma tradição" (MAINGUENEAU, 2008b, p. 98). Usada como frase verbal (voltar/tornar à vaca fria) a expressão geralmente é empregada para convocar, chamar à retomada de algo normalmente pouco prazeiroso. Quem a enuncia assume uma função de "voz da razão", aquela que lembra a obrigação. No universo ficcional da tira a expressão apresenta-se nominalizada, o ato de voltar/tornar já aconteceu. A esse respeito, nos parece pertinente chamar a atenção para o que Maingueneau (2014, p. 29), afirma a respeito das frases nominais. $\mathrm{O}$ autor, retomando Benveniste, relembra que este último destacou que as frases nominais têm valor de argumento e são introduzidas no discurso não para informar, mas sim para agir e convencer. Segundo Maingueneau (idem),

as frases nominais são, ao mesmo tempo, enunciados generalizantes (dimensão referencial), enunciados de autoridade, cuja responsabilidade é atribuída a uma instância que não coincide com o produtor empírico do enunciado (dimensão modal) e enunciados que não são textos (dimensão textual).

Assim, ao fazer uso dessa particitação, o locutor (a) lança mão de um hiperenunciador com atributos de autoridade conferidos pela sabedoria popular ancestral

\footnotetext{
${ }^{98}$ Ver capítulo 1.
} 
que é origem da expressão e (b) mostra a retomada das atividades cotidianas como algo ineludível. Por outro lado, como o personagem encontra-se imóvel diante da mesa, parece-nos que está também retratada a dificuldade dessa retomada, a tensão entre "a diversão" e "a obrigação". Nesse sentido, está presente interdiscursivamente a visão do futebol como um escape dos problemas da realidade diária.

Como procedimento para o humor, identificamos a incoerência insólita pela presença do personagem com o uniforme da seleção- lembrança da copa? - no ambiente de trabalho, e pela própria expressão - de volta à vaca fria - que encerra algo de divertido por juntar dois campos semânticos numa relação inusual (animal e temperatura) e pelo inusitado que é falar de vaca em uma situação de trabalho. Igualmente entendemos que o possível efeito de humor predominante é a conivência lúdica com o leitor-destinatário, que pode identificar-se com esse personagem. Por conseguinte, verificamos também um ethos solidário no emissor do ato de humor que a tira constitui, colocando-se em relação de igualdade com o destinatário.

\subsubsection{A modo de retomada}

Esta parte da análise foi dedicada às tiras publicadas na Folha de S. Paulo no período entre 10 e 15 de julho de 2017, que tiveram como tema o desempenho da seleção do Brasil na Copa de 2014 ou o próprio evento. Na retomada dos acontecimentos, vimos que embora uma vitória da Alemanha pudesse ser esperada, a quantidade de gols conferiu outra dimensão ao fato, que foi interpretado como um vexame e humilhante. Posteriormente o termo "sete a um" passou à discursividade atual do Brasil como sinônimo de adversidade ou situação que envolve humilhação por um gesto ou atitude.

A análise revelou em três produções (figuras 42, 43 e 44) marcas da tensão existente entre o contexto social e político do país e a representação simbólica da derrota, em grande parte construída pela mídia. Sobre esse ponto, mobilizamos reflexões sobre o posicionamento revelado nos enunciados analisados a respeito do papel do futebol na sociedade, segundo o qual se estabelece uma relação polêmica entre apreciar o esporte, vibrar com ele, e vê-lo como um recurso à disposição daqueles que querem ocultar as mazelas do país.

Ainda com relação aos sentidos construídos sobre a Copa do Mundo, uma das tiras tematiza seu aspecto ritualístico, de suspensão do tempo cotidiano. A tira reproduzida na 
figura 49, de autoria de Caco Galhardo, aborda a dificuldade de retomar a rotina diária após a conclusão do evento.

Também nos debruçamos sobre a expressão campeões morais/campeones morales, tentando reconstruir minimamente sua historicidade e interpretando seus efeitos de sentido na relação (ou rivalidade) entre Brasil e Argentina no campo do futebol, concluindo que a expressão traz em si marcas de diferentes momentos vividos pelas seleções dos dois países nas Copas do Mundo de Futebol.

Resumimos no quadro abaixo os procedimentos encontrados para o funcionamento do humor e seus possíveis efeitos, seguindo a classificação proposta por Charaudeau (2006)

\begin{tabular}{|c|c|c|c|c|c|c|c|}
\hline \multirow[b]{2}{*}{ Produção } & \multicolumn{7}{|c|}{ Procedimentos } \\
\hline & 泀 & 总 & 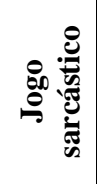 & 吾 & 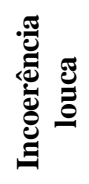 & 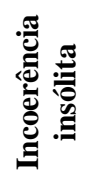 & 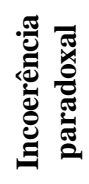 \\
\hline Chico Bacon - Soterrado (Figura 41) & & & & & & $\mathbf{x}$ & \\
\hline Malvados - Realidade, não (Figura 42) & & $\mathbf{x}$ & & $\mathbf{x}$ & & & \\
\hline $\begin{array}{l}\text { Depryzinha - Motivos para deprimirse } \\
\text { (Figura 43) }\end{array}$ & & & $\mathbf{x}$ & & & & \\
\hline O pintinho - Prova-surpresa (Figura 44) & & & & $\mathbf{x}$ & & & \\
\hline $\begin{array}{l}\text { Bifaland - Campeões da Polca } 2014 \\
\text { (Figura 45) }\end{array}$ & $\mathbf{x}$ & & $\mathbf{x}$ & $\mathbf{x}$ & & & \\
\hline Daquiri Vaca-fria - (Figura 49) & & & & & & $\mathbf{x}$ & \\
\hline
\end{tabular}

\begin{tabular}{|l|c|c|c|c|}
\hline \multirow{2}{*}{ Produção } & \multicolumn{3}{|c|}{ Efeitos possíveis } \\
\cline { 2 - 5 } & $\begin{array}{c}\text { Conivência } \\
\text { lúdica }\end{array}$ & $\begin{array}{c}\text { Conivência } \\
\text { crítica }\end{array}$ & $\begin{array}{c}\text { Conivência } \\
\text { cínica }\end{array}$ & $\begin{array}{c}\text { Conivência } \\
\text { de derrisão }\end{array}$ \\
\hline Chico Bacon - Soterrado (Figura 41) & $\mathbf{x}$ & & & \\
\hline Malvados - Realidade, não (Figura 42) & & $\mathbf{x}$ & & \\
\hline $\begin{array}{l}\text { Depryzinha - Motivos para deprimirse } \\
\text { (Figura 43) }\end{array}$ & $\mathbf{x}$ & & \\
\hline O pintinho - Prova-surpresa (Figura 44) & & $\mathbf{x}$ & & \\
\hline $\begin{array}{l}\text { Bifaland - Campeões da Polca 2014 } \\
\text { (Figura 45) }\end{array}$ & & $\mathbf{x}$ & $\mathbf{x}$ & $\mathbf{x}$ \\
\hline Daquiri Vaca-fria - (Figura 49) & $\mathbf{x}$ & & & \\
\hline
\end{tabular}

Como vemos, na maior parte das tiras estudadas o olhar crítico com relação à repercussão da derrota e ao desempenho esteve mais presente. Mediante o jogo paródico, a ironia e o sarcasmo foram questionados diferentes aspectos da sociedade brasileira atual, relacionados ou não ao campo esportivo: a mídia especializada, a teorização 
acadêmica sobre os eventos da Copa do Mundo, as palestras sobre tudo, a inversão de valores que representa a exacerbação dos resultados da Copa.

Nossa interpretação dos possíveis efeitos do ato de humor nas produções reproduzidas nas figuras 42, 43 e 44 nos levou a identificar superioridade intelectual e distanciamento emocional dos eventos da Copa no ethos do emissor do ato de humor configurado nas tiras. Já nas duas produções cuja autoria é de Caco Galhardo (figuras 41 e 49), nas quais interpretamos a conivência lúdica como efeito possível do humor, identificamos um ethos solidário com o leitor, enquanto possível torcedor, e em relação simétrica com ele.

A tira de autoria de Allan Sieber (figura 45) foi a única produção brasileira em que identificamos o uso de estereótipos sobre estrangeiros como recurso para o efeito humorístico nas tiras. Nela verificamos que, além dos jogadores brasileiros, também japoneses, bolivianos e colombianos se converteram em alvo do humor, em objeto do sarcasmo. Nossa interpretação dos efeitos possíveis do humor nesse caso nos levou a três dos quatro tipos de conivência propostos por Charaudeau, a única não contemplada foi a lúdica, aquela em que o emissor do ato de humor busca uma fusão emocional com o destinatário, compartilhando uma visão diferente, bem humorada, sobre algo. Assim, no ethos construído discursivamente para o emissor dessa produção, vemos uma atitude de superioridade que não só critica comportamentos questionáveis como também investe contra tudo e contra todos, desqualificando valores universais de forma gratuita, como pudemos constatar na interpretação que fizemos a respeito da escolha de um personagem japonês para ser alvo do humor na tira. 


\subsection{A Argentina na Copa de 2014}

A seleção argentina chegou à Copa do Brasil comandada por Alejandro Sabella. Classificou-se de forma relativamente tranquila, porém desembarcou no país com o peso de estar há 28 anos sem um título e há 24 sem passar das quartas de final durante os campeonatos mundiais. Seu último título fora em 1990, o vice-campeonato na Itália, em jogo também contra a Alemanha.

Atravessou a fase de grupos também sem muitos problemas, talvez por ter caído em uma chave com adversários mais fracos - Nigéria, Bósnia e Herzegovina e Irã - e garantiu uma das vagas para as oitavas de final. Após passar pela Suiça e pela Bélgica chegou à semifinal contra a Holanda. O rival vinha com o peso simbólico de ser a seleção contra a qual a Argentina disputou a final de 1978 e de ser um país que tem uma argentina como rainha, detalhe abordado em uma das tiras e ao qual nos dedicaremos oportunamente.

Apesar das expectativas que ensejava, visto que se enfrentariam Leonel Messi e Arjen Robben, dois craques de clubes europeus, a partida entre Argentina e Holanda foi avaliada como um jogo ruim pela mídia esportiva. Em seu relato, o jornalista Delfín Melero do portal esportivo Marca comenta que fue un combate nulo que se hizo larguísimo. Argentina y Holanda no pudieron disimular el miedo a morder el polvo y tuvimos un partido sin demasiados riesgos, que tenía que acabar como acabó ${ }^{99}$. E acabou com a vitória da seleção argentina nos pênaltis, classificada para disputar a final contra a Alemanha, país cuja seleção a albiceleste enfrentara em pelo menos quatro Copas anteriores, duas delas em finais.

Os argentinos celebraram a vaga na final como se fosse um título, pois colocava no horizonte não só a possibilidade de obter o tricampeonato, como também de fazê-lo no território do seu gran rival, según la mítica futbolera (ALABARCES, 2015, p. 111) e contra outro rival histórico, a Alemanha. Melero, na conclusão do texto anteriormente citado, expressa desta maneira a expectativa: Ganar el Mundial en Brasil y a Alemania. A pedir de boca.

Porém o sonho não se realizou, oito minutos antes do término da prorrogação, Götze fez o gol que conferiu o tetracampeonato à Alemanha. Apesar da derrota, a

99 Disponível em 〈http://www.marca.com/eventos/marcador/futbol/2014/mundial/semifinal/hol_arg/>. Acesso em 08/05/2017. 
imprensa argentina enalteceu a atuação da seleção do país. Nas manchetes dos jornais que circularam na segunda-feira seguinte, 14/07/2014, as ideias recorrentes eram de orgulho, dignidade, valentia, como podemos observar nos exemplos que trazemos ${ }^{100}$ :

Sin Copa, con orgullo. [La Nación]

Argentina peleó hasta el final. [Clarín]

Tristeza y orgullo. [Crónica]

Con la frente alta. [El Argentino]

Dieron todo. [Muy]

Subcampeones -Argentina cayó, pero se retiró con orgullo. [Diario de Cuyo]

Argentina corazón valiente [ La mañana de Córdoba]

Esses enunciados envolvem basicamente os semas valentia, garra, persistência e orgulho em relação de causa e efeito: perderam, mas lutaram até o final; deram tudo de si. Além do vínculo metafórico com a luta, a guerra, esses valores dialogam com um imaginário que envolve a noção de masculinidade, tema que Eduardo Archetti (1995) e Pablo Alabarces (2002), pesquisadores que têm o futebol como objeto de estudo na Argentina a partir das Ciências Sociais, já apontaram como uma das dimensões envolvidas na construção das representações do futebol nesse país.

No próximo item abordaremos como os acontecimentos que comentamos, e que dizem respeito à seleção argentina de futebol na Copa de 2014, foram tematizados nas tiras cômicas publicadas no jornal Clarín no período final do campeonato.

\footnotetext{
${ }^{100}$ Material disponível em http://www.minutouno.com/notas/329633-las-tapas-todos-los-diarios (acesso em 05/06/2017.
} 


\subsubsection{A seleção argentina, a Copa de 2014 e as tiras do Clarín}

Nas linhas que seguem apresentaremos a análise de seis tiras publicadas entre os dias 10 e 15 de julho de 2014, exatamente o mesmo período em que foram publicadas as brasileiras que foram objeto da análise anterior. Naquele então, a seleção argentina já havia se classificado para a final em vitória contra a seleção da Holanda e a seleção do Brasil, por sua vez, também já havia passado pelo 7 a 1 contra a Alemanha.

Nas duas primeiras produções que abordaremos, o tema é a classificação da seleção argentina para a final e nelas o Brasil aparece explicitamente como o Outro sobre o qual se trata de construir uma superioridade. A seguinte trata da ansiedade que significa para o torcedor a espera pela final, mas interdiscursivamente mobiliza uma visão a respeito do papel da seleção argentina que é relevante apresentar. As três últimas trazem interpretações sobre o resultado do jogo final: a derrota frente à Alemanha ou a conquista do vice-campeonato, segundo o ponto de vista adotado.

\subsubsection{La Nelly - Súbditos}

A primeira a ser analisada é a tira La Nelly, de autoria de Sergio Langer e Rubén Mira e está reproduzida na figura $50^{101}$.

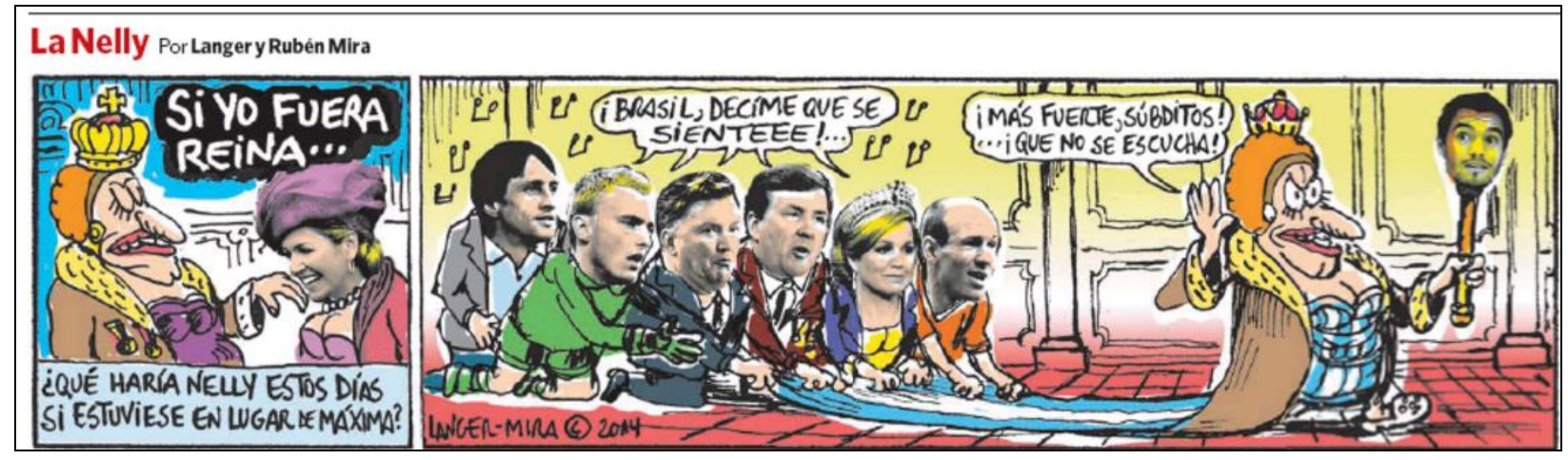

Figura 50 - La Nelly - Súbditos - Fonte: Clarín de 10 de julho de 2014

\footnotetext{
${ }^{101} \mathrm{Na}$ segunda vinheta, as pessoas cujas fotos estão reproduzidas nos rostos dos personagens que seguram o manto de Nelly são, da esquerda para a direita, respectivamente: Johan Cruijff - talvez o maior dos jogadores holandeses, Jasper Cillessen - goleiro da Holanda, Louis Van Gaal - técnico da seleção holandesa em 2014, Willem-Alexander - atual rei da Holanda, Máxima Zoguerrieta - rainha consorte da Holanda, Arjen Robben - jogador holandês. No cetro que Nelly segura está reproduzido o rosto de Sergio Romero, goleiro da Argentina. Agradecemos a Nicolás Lepratti e Pedro Sciola de Oliveira pela ajuda na identificação.
} 
A tira La Nelly é uma tira de personagem fixo assinada por dois autores, algo comum no âmbito das revistas de aventura e de super-heróis, mas raro entre as tiras cômicas publicadas em jornais diários.

A produção em análise é parte da série Si yo fuera reina que teve no total 4 tiras, publicadas diariamente entre 07 e 10 de julho. A razão era o fato de a seleção da Holanda ser, naquele então, a próxima rival da equipe albiceleste. $\mathrm{O}$ enfrentamento encerrava suas peculiaridades, posto que desde 2002 uma argentina passou a fazer parte da família real holandesa. La reina do título se refere a Máxima Zorreguieta ${ }^{102}$, atualmente rainha consorte da Holanda. Essa tira que ora analisamos foi a última da série, saiu no dia seguinte à vitória da Argentina. Nela, a imagem da rainha, seu título, seu nome, são as informações que circunscrevem o tema. Faz-se necessário aqui uma pequena síntese sobre o tratamento que recebe a rainha consorte por parte da mídia argentina.

Máxima é personagem frequente das revistas de celebridades da Argentina, porque sua história é um prato cheio para o nicho em que atuam. Em 2002, ano de seu casamento, a Argentina enfrentava talvez a pior de suas crises econômicas, com a população passando por sérias privações. Em flagrante contraste, as revistas e programas de televisão argentinos dedicados às celebridades destinavam incontáveis horas e páginas a tudo que envolvia a cerimônia. $\mathrm{O}$ mesmo se deu em 2013, quando foi alçada à condição de rainha consorte. Durante os dias que antecederam a partida semifinal em 2014, também foi tema recorrente na mídia a indagação sobre para quem a rainha torceria. Parece ser que essas questões são muito mais uma criação da mídia do que algo com que se preocupe efetivamente a população argentina em geral. Para além do alcance da pregnância que a história de Máxima e seu dia a dia possam ter para a população argentina, nos interessa aqui evidenciar que a personagem Nelly, por sua vez, representa o oposto de tudo isso. A começar pelo seu aspecto físico grotesco, o corpanzil sempre apertado em roupas justas, o nariz enorme, a papada, as situações que vivencia. Segundo Martignone e Prunes (2008, p. 105), a personagem de Mirá e Langer reúne, de forma exagerada, praticamente tudo o que é considerado de mau gosto ou vulgar ${ }^{103}$ pela elite sócio-econômica do país.

\footnotetext{
${ }^{102}$ Nascida na Argentina, oriunda de uma família de alta condição econômica, Máxima Zoguerrieta formouse em economia e foi trabalhar em Nova Iorque. Ali conheceu o então príncipe Willem-Alexander. Casaram-se em 2002 e em 2013, com a entronização do marido, converteu-se na primeira latino-americana a ser coroada rainha consorte de um país europeu.

${ }^{103}$ Martignone e Prunes (2008, p. 105) a respeito de Nelly, dizem que ela sintetiza o universo mersa. Segundo o Diccionario de habla de los argentinos (2003), a palavra é de uso coloquial e despectivo e tanto pode referir-se a pessoas de usos e costumes vulgares como de baixa condição social
} 
Retomando a descrição da tira, nela temos duas vinhetas, perfeitamente demarcadas. A parte não verbal mescla uso de desenhos com fotografias, a modo de colagem, também uma marca do estilo dos autores. À divisão corresponde não só uma mudança de cenário, como também de cenografia enunciativa e de temporalidade no interior ficcional.

Comecemos pela primeira vinheta, que na série da qual a produção em foco faz parte era sempre igual. Nela, Nelly aparece vestida de rainha, com coroa, manto, e é Máxima quem a reverencia, beijando sua mão (ou um anel). Há duas vozes no plano ficcional. A primeira, é de Nelly, como locutor-personagem. O Yo do título Si yo fuera reina... refere-se a ela. A pergunta contida na legenda corresponde à voz do locutornarrador, na parte inferior. Nesse enunciado, o dêitico estos ancora a tira no tempo que corresponde à sua situação de enunciação, refere-se ao período anteriormente mencionado - entre 7 e 10 de julho. Esse recurso torna difuso o limite entre o plano da ficção e o da realidade: é como se Nelly realmente existisse. Ambos os enunciados estão expressos na forma de períodos condicionais hipotéticos ou potenciais. O que corresponde à personagem Nelly está em um balão-fala que não tem o chamado rabicho, o que indica que se trata de seu pensamento. O período apresenta-se incompleto, nele só consta a prótase, a oração em que se apresenta a condição hipotética (ser reina) que, caso realizada, possibilitaria a consequência, que fica em suspenso. No enunciado que corresponde à voz do narrador, por sua vez, o período condicional apresenta-se como uma interrogação, com o núcleo incidindo sobre o que poderia fazer Nelly na suposta condição de rainha. Como vemos, os dois enunciados da primeira vinheta introduzem um suspense na narrativa ficcional, ademais propõem uma situação hipotética e convidam o interlocutor a adentrar a outro plano temporal dentro da ficcionalidade. A prótase sem apódose cria um efeito de fantasia que permite sonhar com múltiplas possibilidades, realizáveis ou não.

No âmbito da interlocução com o leitor, a cenografia enunciativa, segundo nosso ponto de vista, instaura a uma narrativa cinematográfica (ou televisiva): a cena enquadra um protagonista diante de uma situação, ouve-se um narrador - em off -, dirigindo-se diretamente ao espectador e apresenta uma questão que será respondida na cena seguinte. Essa possibilidade dialoga com a estreita relação entre quadrinhos e cinema, já discutida por diversos estudiosos do tema, tais como Moacy Cirne, Álvaro de Moya e Umberto Eco. 
A segunda vinheta mostra graficamente a resposta à pergunta do locutor- narrador. A passagem de uma vinheta a outra instaura o plano da ficção - cena da segunda vinheta dentro da ficção. Se fosse reina, Nelly usaria um vestido com as cores da bandeira argentina, estamparia em seu cetro o rosto do goleiro Sergio Romero, porque ele defendeu dois pênaltis dos holandeses dando a vitória aos argentinos, colocaria um manto enorme e faria com que jogadores e técnicos holandeses de futebol, bem como a rainha e o rei da Holanda o carregassem cantando a música Brasil, decíme que se siente. Dessa forma, humilha não só os holandeses, como também os brasileiros - o Outro sempiterno no campo futebolístico, aspecto que abordaremos na análise da próxima tira, que também mobiliza a rivalidade com o Brasil. Quanto aos holandeses, não só carregam o manto de Nelly, como o fazem de joelhos. Recordemos que entre eles estão os próprios reis da Holanda. Além disso, o enunciado contido no balão-fala de Nelly, como locutorapersonagem, é uma ordem - devem cantar mais alto porque não se escuta - e nele a personagem se dirige aos holandeses tratando-os de súbditos ${ }^{104}$. É difícil pensar em rebaixamento maior para os limites permitidos em um jornal como o Clarín: os reis de joelhos, carregando o manto de uma argentina representante do que há de mais popular no país e sendo chamados de súditos.

A canção que cantam os holandeses, como parte do repertório de humilhações a eles impingida pela reina Nelly se converteu no hino dos argentinos no Brasil durante a Copa de $2014^{105}$. Em texto publicado durante a Copa, García (2014) refaz o percurso que o tema percorreu até a Copa de 2014. O autor aponta que a melodia de Brasil decíme qué se siente é uma versão entre murga e cumbia de Bad Moon Rising, uma canção do grupo de rock estadunidense Creedence Clearwater Revival, gravada em 1969. Em Alabarces (2015), que também se debruça sobre o tema em um artigo, encontramos que antes de chegar à versão que circulou no Mundial de 2014, a melodia serviu de base para um tema de militância política adotado pela juventude kirchnerista ${ }^{106}$ e para um canto de torcida do

\footnotetext{
${ }^{104}$ Chamamos a atenção para um comentário do escritor Jorge Luis Borges a respeito desse termo. Em seu texto El idioma de los argentinos de 1927, o autor afirma que a palavra "súbdito es decente en España y denigrativa en América", porém não desenvolve a ideia. Nossa interpretação a respeito é porque a relação com a coroa havia sido diferente na América e na Espanha. Texto disponível em <https://edisciplinas.usp.br/pluginfile.php/498411/mod_resource/content/1/-El-Idioma-de-LosArgentinos\%2C\%201928Ensayo.pdf> . Acesso em 09/07/2017.

${ }^{105}$ Para uma análise mais completa de Brasil decíme qué se siente remetemos à leitura dos dois autores aqui citados, García (2014) e Alabarces (2015) que fazem uma reflexão bastante aprofundada do tema.

${ }^{106}$ Trata-se do coletivo La Cámpora, um agrupamento político formalmente criado em 2006 de orientação peronista e kirchnerista.
} 
time de futebol San Lorenzo. O autor destaca, no entanto, a dificuldade em precisar qual adaptação surgiu primeiro, se a da política ou a do futebol.

Em nossa análise, com base em Maingueneau (2008, 2014) vimos apontando as produções em que aparecem particitações e em que se instaura um hiperenunciador. $\mathrm{O}$ autor francês propõe algumas reflexões a partir dos vários tipos de particitações que identifica, como já apontamos no capítulo em que apresentamos a fundamentação deste trabalho. A partir das informações que acabamos de trazer, o caso de Brasil decíme qué se siente adquire dimensões que tornam mais complexa sua classificação e, consequentemente, as reflexões que acarretam para o correspondente hiperenunciador quando enunciadas.

Como vimos, a melodia, no âmbito da Argentina, é reconhecidamente um tema usado tanto na política como no futebol, com as correspondentes letras, obviamente. Assim, foi reinvestida simultaneamente como um slogan político e um canto de torcida. Além disso, diferentemente de outros casos de particitações, há uma autoria conhecida e seus autores recebem direitos autorais por sua execução ${ }^{107}$. Esses detalhes passam despercebidos se pensamos nos brasileiros que a escutaram aqui em seu próprio país, nas infindáveis manifestações dos torcedores argentinos que compareceram massivamente ao Brasil para acompanhar a Copa. Por outro lado, parece-nos que não podem ser ignorados se pensamos que os estamos enfocando como um enunciado de uma tira publicada em um jornal na Argentina. Entendemos, portanto, que o hiperenunciador que emerge da reprodução dos versos da canção na tira tem características que dizem respeito ao pertencimento à homogeneidade que se configura sob o título "torcedores argentinos", com ecos da afirmação de uma força no campo político, no caso, o kirchnerismo e, por conseguinte, o peronismo. Considerando que o jornal Clarín e o governo Kirchner estavam em campos opostos da disputa no terreno político, os potenciais efeitos de sentido da publicação dessa tira não deixam de guardar certa ironia.

Passando aos recursos para a construção do humor nessa produção, para que ela tenha graça, é preciso que o leitor, como destinatário do ato de humor que a tira constitui, desvende o emaranhado de referências presentes no texto e, para tanto, precisa mobilizar uma série de informações implícitas. Como vimos, o humor se dá basicamente sobre a inversão de lugares entre "povo" e "realeza" e o rebaixamento dos alvos, que entendemos

\footnotetext{
107 Alabarces (2015) aponta que os versos de "Brasil decime qué se siente" fueron escritos por un tal Ignacio Harraca, amigo de un tal Diego Scordo, que a su vez la registró en la Dirección Nacional de Derechos de Autor para que sea regida por los beneficios de la ley 11.723, que ordena los derechos de autor en la Argentina" (op. cit. p. 101)
} 
nesse caso ser duplo: os holandeses e os brasileiros. Assim, entendemos com Charaudeau (2006) que o humor se dá por procedimentos que envolvem um jogo enunciativo sarcástico, porque os alvos são depreciados, humilhados. Por conseguinte, vemos como efeito pretendido o que o autor classificou como conivência de derrisão com o destinatário, aquela em que, por meio do rebaixamento, busca-se compartilhar uma visão distanciada - ou de desprezo - sobre algo que é supervalorizado, no caso a aura da realeza e a pretensa superioridade do futebol de um país europeu - representados em seus jogadores e técnicos - frente aos latino-americanos.

\subsubsection{Diógenes y el linyera - La alegría es argentina}

A próxima tira a ser analisada é uma produção de Tabaré, uruguaio radicado na Argentina. Trata-se da tira Diógenes y el linyera reproduzida na figura 51.

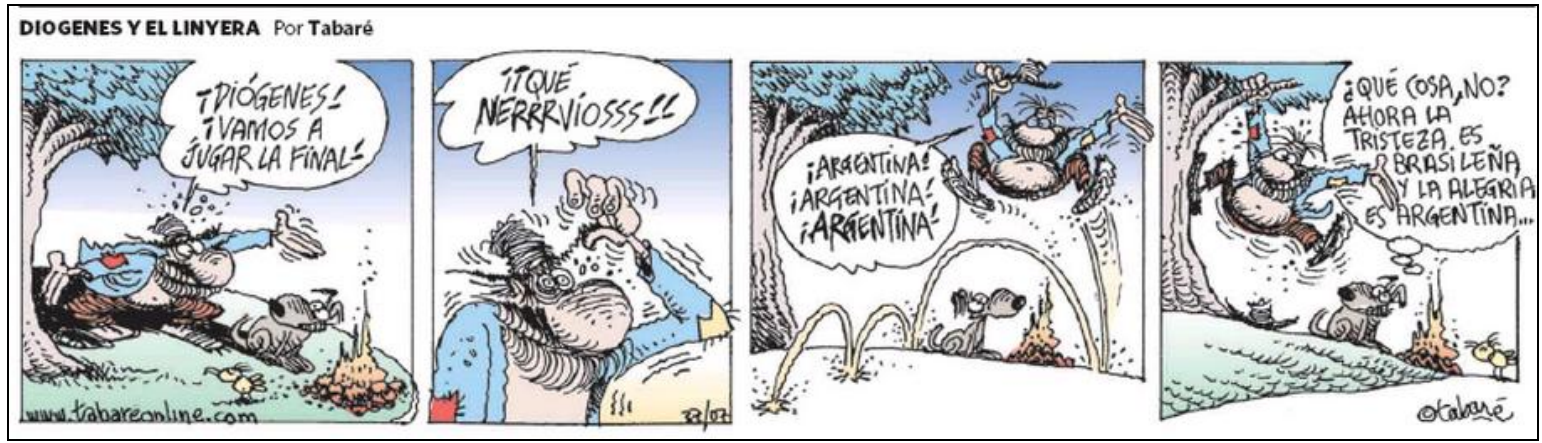

Figura 51 - Diógenes y el Linyera - La alegría es argentina

Fonte: Clarín de 11 de julho de 2014

Diógenes y el linyera ${ }^{108}$ talvez seja a tira mais antiga entre as que são publicadas atualmente na última página do Clarín. Seus protagonistas são um mendigo e seu cachorro. Diógenes é o cão e, como características do filósofo grego que lhe dá nome, tem não só a pobreza como também um ethos de sabedoria. Nas tiras, ele tem a última intervenção, em balões-pensamento em que faz um comentário a respeito da situação vividas por el linyera, normalmente reflexões irônicas que trazem o desfecho humorístico.

A produção que analisamos se desenrola num cenário típico das narrativas da tira: uma praça, ao lado uma fogueira. Nela intervêm somente os dois personagens que dão nome à tira. A cenografia é a de uma conversa entre duas pessoas, em que uma participa

\footnotetext{
${ }^{108}$ Linyera em espanhol significa pedinte, mendigo. O nome vem da trouxa que normalmente os mendigos carregam e que recebe o mesmo nome.
} 
uma boa-nova à outra. $\mathrm{O}$ enunciado do primeiro balão-fala provém do personagemlocutor El linyera. Nele anuncia efusivamente ;Vamos a jugar la final! ao cachorro. Com isso, circunscreve o tema da narrativa, o implícito é que a seleção argentina de futebol fora classificada para a final da Copa. O personagem faz o anúncio usando nosotros. Obviamente somente os jogadores disputarão a partida, mas mediante o uso do pronome, o personagem mobiliza a noção de unidade que representa o país e seus habitantes. Tratase portanto de um nosotros inclusivo cujo referente inclui os personagens do plano ficcional, o leitor da tira, e a abstração homogeneizada sob o nome de "nação Argentina".

$\mathrm{Na}$ vinheta seguinte, o mesmo personagem expressa sua excitação no enunciado iiQué nerrrvios!!! Os vários sinais de exclamação e a reiteração da letra $r$ no balão-fala, bem como as linhas cinéticas ao redor do seu corpo funcionam como recursos expressivos para enfatizar seu estado de ânimo diante da classificação. $\mathrm{Na}$ vinheta seguinte o personagem é mostrado como se houvesse dado vários saltos, várias linhas cinéticas vão de seu corpo em direção ao solo, indicando o movimento de sobe e desce. No balão-fala, três vezes o nome Argentina entre sinais de exclamação, algumas letras em negrito, o que expressa que enquanto pula, "grita" o nome do país. O exagero caricatural da demonstração de alegria do personagem confere comicidade às cenas.

$\mathrm{Na}$ última vinheta, com a reflexão do cachorro Diógenes em um balão-pensamento opera-se um jogo enunciativo irônico, com o efeito de sentido colocado pelo que não está dito. Para explicá-la, seguindo novamente a proposta de Ducrot (1984), entendemos que o locutor-personagem Diógenes se desdobra em dois enunciadores: (E1) ¿Qué cosa, no? e (E2) Ahora la tristeza es brasileña y la alegría es argentina... A oração interrogativa introdutória expressa uma surpresa que, de nosso ponto de vista, traz ambiguidade para o enunciado. Qual é a razão da surpresa? A efusividade de el Linyera, a classificação para a final ou o resultado inesperado do Brasil?

No que se refere à constatação do E2, resposta à pergunta retórica do E1, se não forem mobilizados conhecimentos da exterioridade não ficcional é insólita e fora de propósito. Qual a razão da comparação com os brasileiros que sequer haviam sido mencionados pelo outro personagem-locutor? Para a construção do sentido dessa tira é preciso buscar os implícitos na situação de comunicação - a derrota para a Alemanha - e nas representações simbólicas envolvidas na relação entre brasileiros e argentinos no campo do futebol, entre as quais a antítese alegria-tristeza parece ser uma constante.

Começando pela primeira, seja pelos organismos oficiais, seja pela indústria cultural, exportou-se um imaginário sobre o Brasil baseado em samba, Carnaval, 
capoeira, mulatas, sol, praia etc. Merenson (2007) em pesquisa realizada na Argentina sobre estereótipos sobre os brasileiros aponta que a alegria, a diversão, a despreocupação estava entre os mais correntes ${ }^{109}$. Por outro lado, quando se trata especificamente da relação/rivalidade entre Brasil e Argentina no futebol, entra em jogo o sentimento oposto: a tristeza. Recordemos, a esse respeito, a fala que já citamos do comediante Landriscina no documentário La fiesta de todos sobre a Copa de $1978^{110}$ da qual o enunciado de que tratamos é praticamente uma paráfrase. Cabe acrescentar que em nossa pesquisa nos chamou a atenção a frequência com que encontramos a antítese em manchetes sobre resultados de jogos envolvendo o Brasil ou Brasil e Argentina como adversário.

O fato também é destacado por Helal (2006) quem inclusive aponta que a canção Yo no quiero volverme tan loco do músico e cantor Charly García traz em um de seus versos a afirmação La alegría no es solo brasileira ${ }^{111}$. No artigo citado, uma das publicações originadas de um projeto em que o autor analisa a cobertura jornalística de partidas de futebol em diferentes períodos compreendidos entre 1970 e 2006, Helal considera que em algumas das narrativas da imprensa relevava-se certo ressentimento, como se os argentinos não tivessem essa alegria. $\mathrm{O}$ autor menciona uma charge publicada na seção de cultura do Clarín do dia 30 de junho de 2005 na qual se viam os mapas do Brasil e da Argentina, com a seguinte legenda: “'Una transfusión de alegría, por favooor! (op. cit., p. 12). Uma de nossas percepções sobre os enunciados que analisamos dialoga com a suposta ausência de alegria argentina apontada por Helal. Parece-nos que o advérbio ahora que introduz a afirmação do E2 traz implícita a idea de uma anterioridade em que os atributos eram diferentes (cf. MATTE BON, 2010), ou seja, que antes la tristeza era argentina y la alegría era brasileña. Cabe destacar também o fato de o Brasil ser nomeado e não a Alemanha, o rival de fato na partida final, o que, em nosso ponto de vista, dialoga com algo também apontado por Helal (2007). Segundo ele, a rivalidade entre os países envolve manifestações de contentamento pelos resultados ruins do "outro", o "torcer contra". Assim, parece-nos que recordar ao leitor-implícito argentino o resultado ruim do Brasil poderia aumentar a satisfação pela classificação de seu país.

Para concluir, como efeitos pretendidos pelo humor entendemos que se misturam a conivência lúdica - compartilhar o estado de euforia pela classificação - com a

\footnotetext{
${ }^{109}$ Embora não seja citada explicitamente, a canção A felicidade de Vinícus e Tom Jobim veio à memória de várias pessoas que leram esta tira em uma consulta informal. Como a canção é citada intertextualmente em uma das tiras analisadas, será oportunamente abordada.

110 Ver página 178.

${ }^{111}$ A letra completa da canção se encontra no Anexo.
} 
conivência crítica, pela forma como se encerra a tira. Considerando o ethos de um enunciador filosófico que caracteriza o personagem do cão, vemos presente uma espécie de lembrete sobre a alternância e a efemeridade dos resultados esportivos. Para que alguém ganhe e se alegre, alguém tem de perder, e se entristecer.

\subsubsection{Donatela - Hinchada histórica}

No conjunto de tiras argentinas de nosso corpus há uma única mulher como autora. Trata-se de Diana Raznovich. Ela assina a tira Donatela, da qual analisaremos duas produções, a primeira delas está reproduzida na figura 52.

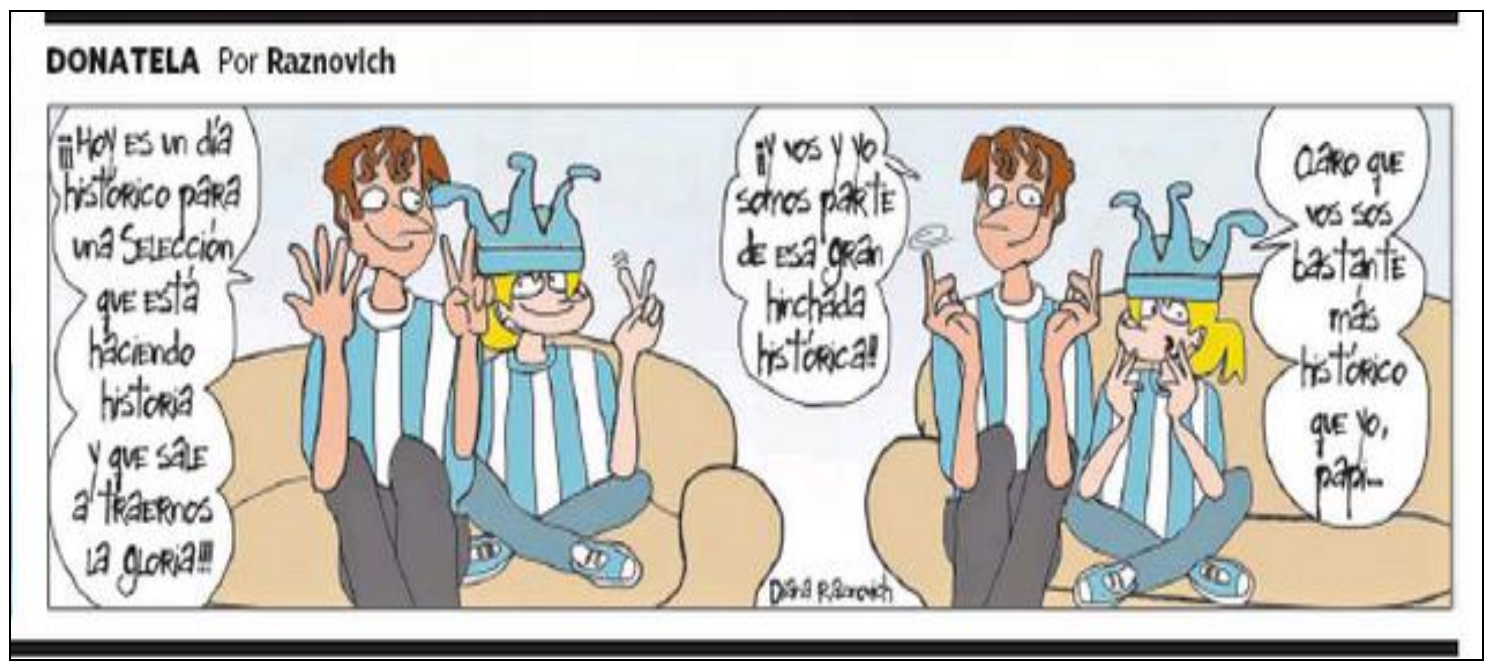

Figura 52 - Donatela - Hinchada histórica - Fonte: Clarín de 13/07/2014

Donatela é uma tira fixa que leva o nome da principal protagonista, que não é sua única personagem. As narrativas giram em volta dela, de sua família e suas amizades. Ao longo da Copa, Raznovich publicou uma sequência de produções que tinham como protagonistas a filha e o marido de Donatela e cuja temática era a iniciação da filha como torcedora da seleção argentina de futebol. Nesse sentido, há várias informações implícitas para o leitor, como destinatário da tira e dos atos de humor que encerra, que decorrem do fato de ela inscrever-se nessa sequência: quem são os personagens, a relação entre eles, a situação retratada etc. Uma dessas informações refere-se ao cenário, que era sempre o mesmo: pai e filha sentados no sofá, vestidos com as cores da bandeira argentina e algum adereço que faz parte dos rituais da torcida, nesse caso especificamente, um chapéu com três pontas. Passando à descrição dos outros elementos 
não verbais que compõem a cena, os personagens fazem alguns sinais com as mãos: o pai, mostra sete dedos e a filha, dois. Nossa interpretação é que possivelmente se refiram respectivamente aos gols sofridos pela seleção do Brasil e aos dois pênaltis defendidos por Sergio Romero na partida anterior contra a Holanda, numa referência velada ao rival derrotado e ao Outro frente ao qual é preciso se afirmar.

Os dois primeiros balões-fala procedem do pai como locutor-personagem. A cenografia que seus enunciados instauram guarda certa incongruência com as criadas pela parte imagética da tira. Vamos a eles:

$1^{\circ}$ balão-fala: Hoy es un día histórico para una selección que está haciendo historia y que sale a traernos la gloria.

$2^{\circ}$ balão-fala: $Y$ vos y yo somos parte de esa gran hinchada histórica.

Como sabemos, a tira foi publicada no dia em que a Argentina disputaria a partida final da Copa, o advérbio hoy é um dêitico que se refere ao dia 13/07/2014. Na sequência, adjetivos e orações adjetivas qualificam o dia, a seleção e a torcida. Há uma reiteração do traço semântico história nesse processo. O dia é histórico, a seleção está haciendo historia, a torcida é histórica. O uso do Presente do Indicativo, a ausência de traços modalizadores conferem valor de assertividade aos enunciados. Como vemos, em lugar da cenografia de uma conversa entre pai e filha sobre o jogo ou sobre a ansiedade da espera - possível expectativa por parte do leitor -, a fala do pai traz marcas de uma narração épica em que há elementos de heroicidade, pois a seleção foi em busca da gloria. Essas características são marcas também de falas de autoridades em discursos de recepção a pessoas que se destacaram por algum feito. Entendemos que ambas possibilidades poderiam funcionar como cenas validadas para o enunciado do locutorpersonagem pai.

Outra questão relevante a ser destacada refere-se à forma como são referidas as instâncias de pessoa nos enunciados da tira. Diferentemente do que vimos na tira de Diógenes y el linyera e nas de Clemente referentes a 1994, nas quais os locutorespersonagens usavam nosotros e se incluíam como agentes da participação na Copa ${ }^{112}$, no primeiro enunciado, embora adote nosotros, o locutor-personagem, embora coletivo, é o beneficiário do processso: traernos la gloria. No segundo enunciado explicita-se o papel que terá no processo - juntamente com a filha, sua interlocutora no plano ficcional: ser parte da gran hinchada histórica. Isso é feito mediante predicação

${ }^{112}$ Ver análises referentes às figuras 23, 24 e 51. 
nominal, os sujeitos implicados nos pronomes vos y yo não são agentes de um processo. Assim, parece-nos que o ponto de vista adotado pelo emissor do texto que constitui a tira para seus personagens é externo aos eventos dos quais se fala - a Copa. A participação dos personagens será o encorajamento (hinchar), mas não se incluem simbolicamente como participantes ativos no processo.

À filha cabe a última fala, que trará o efeito humorístico que encerra a tira. Novamente temos um ato de humor que se dá pelo jogo irônico, nesse caso construído com uma polissemia sobre adjetivo histórico: Claro que vos sos bastante más histórico que yo, papi... O dito é que o pai é muito mais histórico que ela, o não dito, que ele é antigo, ou seja, velho. No procedimento opera-se também um rebaixamento sobre tudo o que o pai dissera antes, apaga-se o valor de importância, consagração que o adjetivo histórico (a) tinha nos enunciados do pai e sobrepõe-se o de antiguidade. $\mathrm{O}$ alvo do ato de humor é o pai, como personagem, porém simbolicamente parece-nos que esse alvo pode ser ampliado tanto para o lugar de fala de autoridade que assume na relação paifilha, como também para o que ele, como locutor-personagem, constrói discursivamente sobre a seleção. Ou seja, o alvo também poderia ser a assemelhação entre o desempenho da seleção argentina e uma campanha pela glória do país. Essas interpretações nos levam a ver a conivência crítica como um possível efeito visado pelo humor nessa tira, criticidade essa que também identificamos no ethos de seu emissor.

Chegamos finalmente às três últimas produções a serem analisadas. As duas primeiras saíram publicadas na segunda-feira seguinte à final, no dia em que os jogadores foram recebidos em Buenos Aires. Começaremos por aquela em que o vicecampeonato da seleção argentina é visto de forma mais positiva, coincidentemente é mais uma tira Donatela, de autoria de Diana Raznovich. 


\subsubsection{Donatela - Bienvenidos héroes}

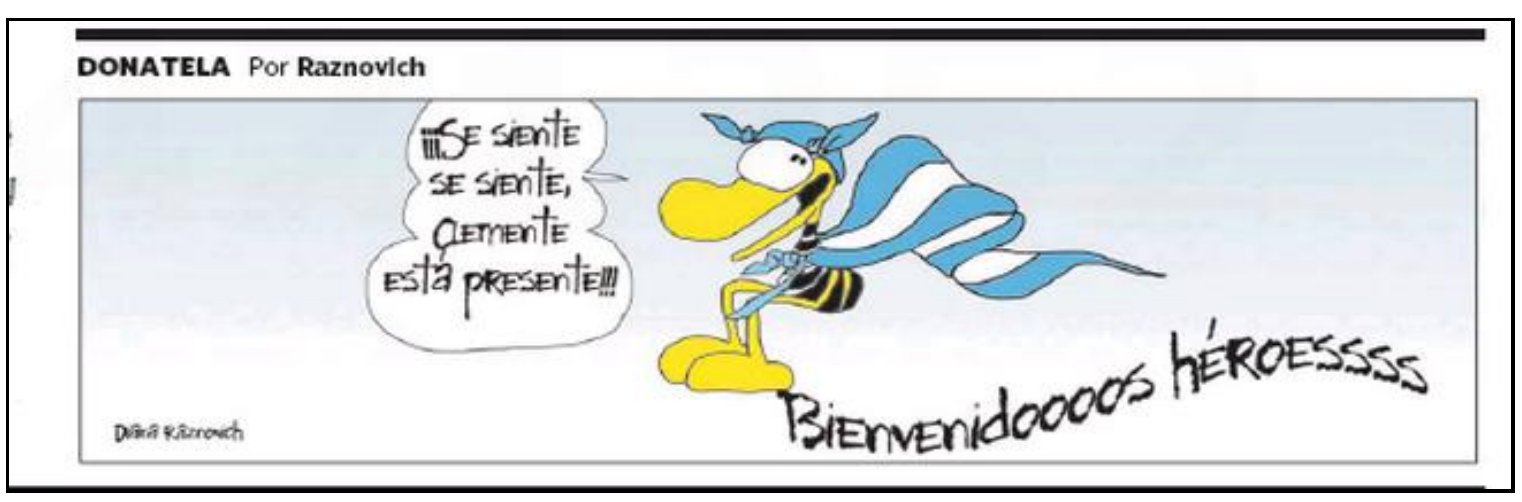

Figura 53 - Donatela - Bienvenidos héroes - Fonte: Clarín de 14/07/2014

Como vemos, nela aparece o personagem Clemente e se trata claramente de uma homenagem a Caloi, seu autor. Outros quadrinistas também o fizeram, desenhando o personagem em suas tiras para abordar o desempenho da seleção em $2014^{113}$. A presença do personagem Clemente foi uma constante na elaboração simbólica sobre o desempenho da seleção argentina nos Mundiais de futebol. Porém no caso de Diana Raznovich, certos dados conferem detalhes à homenagem que a diferenciam das outras.

A quadrinista começou a publicar no Clarín em setembro de $2012^{114}$, após o falecimento de Caloi e explicitamente para ocupar o lugar que fora dele no grupo de autores da última página do diário. Ademais, a Copa de 2014 seria a primeira, depois de mais de trinta anos, em que as histórias de Clemente não seriam publicadas. Cremos que é possível afirmar que a homenagem era quase ineludível. Raznovich desenhou o personagem com a vestimenta que o caracterizava durante os mundiais de futebol: o sombrero de cuatro nudos azul e uma capa com as cores da bandeira da Argentina. Ele está em um fundo azul claro, como se estivesse saltando ou voando. A imagem circunscreve o tema para o leitor, trata-se de uma tira que versará sobre o vicecampeonato da seleção.

\footnotetext{
${ }^{113}$ Conforme já comentamos, nas nove edições da Copa do Mundo ocorridas entre 1978 e 2010, alguns dias antes do campeonato e ao longo do tempo que durava o evento, Caloi colocava seu personagem Clemente praticamente à serviço da seleção argentina e da Copa. Some-se a isso o episódio dos papelitos, também já referido neste trabalho, e teremos razões que explicam a presença do personagem em três das cinco produções gráficas da página de humor do Clarín e também em uma tira do La Nación, outro jornal diário argentino, em 14 de julho de 2014. Tanto a página do Clarín como a tira do La Nación estão reproduzidas no como anexos.

${ }^{114}$ Informação disponível em <https://www.clarin.com/sociedad/llega-clarin-historieta-familiadonatela 0_ByBgA51hDXl.html $>$. Acesso em 01/07/2017.
} 
Na parte verbal, vemos um balão-fala que sai do personagem no qual se lê ii iSe siente, se siente, Clemente está presente!!! e abaixo, como uma legenda, a frase: Bienvenidooooos héroesss, na qual a repetição da vogal o no adjetivo e da consoante no substantivo héroes funcionam como recursos expressivos para indicar que ambas as palavras se diriam de forma prolongada, numa demonstração de efusividade e alegria.

Comecemos nossa reflexão pela legenda. Nela vemos retomada a ideia de heroicidade que aparecera na tira publicada no dia anterior por Raznovich e que também analisamos. Entendemos que o enunciado está congruente com o discurso da mídia do país a respeito do desempenho da seleção argentina: embora não tivessem ganho o campeonato, lutaram até o final e nesse sentido, honraram o país. A cenografia que ele instaura também tem congruência com os fatos da exterioridade, a chegada da seleção.

O enunciado do balão-fala, por outro lado, instaura uma cenografia diferente. Nossa pesquisa apontou que o canto Se siente, se siente Fulano está presente é bastante usado em países hispanofalantes na América Latina, sobretudo em contextos políticos. Nesses casos, quando se trata de uma campanha, para rimar com se siente encontramos também o substantivo presidente. Na Argentina ${ }^{115}$, uma versão muito parecida faz parte do repertório de cantos entoados nos anos 70 que constam no site Soloperonista ${ }^{116}$. No que se refere à versão que está na tira, se substituirmos Clemente por Evita, temos a canto que se escuta em homenagem a Evita Perón, especialmente no aniversário de sua morte. O paradoxo - embora ausente, está presente - reafirma a vigência dos valores simbólicos associados a ela e do mito que representa.

Pelo exposto, entendemos que podemos interpretar o procedimento como uma particitação de grupo com caráter militante (cf. MAINGUENEAU, 2008, 2010), que por sua vez convoca um hiperenunciador que funde as convicções e valores do coletivo que representa. Caloi se declarava peronista e alguns dizem encontrar em Clemente traços disso, como se a criatura compartilhasse da mesma convicção política do criador $^{117}$. De fato, acompanhando as publicações da tira ao longo dos anos, vemos que pela voz de

\footnotetext{
${ }^{115}$ Agradecemos a Ramiro Caggiano Blanco os informações e indicações de fontes que nos auxiliaram na análise desta tira de Raznovich e na próxima, de Sendra.

${ }^{116}$ A versão que se encontra no site é Se siente, se siente, Evita está presente en cada combatiente. Disponível em <www.soloperonistas.com /canticos70s.html>

${ }^{117}$ Em entrevista a Felipe Pigna para o programa Qué fue de tu vida levada ao ar em 22 de julho de 2011, Caloi dá detalhes de seu envolvimento com a militância en las fileiras da Juventude Peronista. Na mesma entrevista, afirma que ele é peronista, mas que Clemente era uma personagem, reafirmando limites entre ficção e realidade que muitas vezes eram esquecidos quando falavam de Clemente. Entrevista disponível em < https://www.youtube.com/watch?v=ZOxbx1AMrMo> e

<https://www.youtube.com/watch?v=yXJag4KmGMg>
} 
Clemente se desnudavam mazelas sociais e outras questões dentro do campo político argentino que podiam ser consideradas como alinhadas com a esquerda e, em certa medida, com o peronismo - e em franco desacordo com a linha editorial do Clarín, especialmente durante o governo de Cristina Kirchner. Nesse sentido, a voz de Clemente servia para mediar a expressão da opinião de seu autor, como nos sinalizou Hernán Martignone ${ }^{118}$.

Portanto ao trazer para a tira esse canto, Raznovich evoca não só a presença do personagem e de seu autor, como também sua filiação política, seu compromisso com o social e, talvez, sua militância ao usar o espaço como exercício do direito de manifestar suas convicções. Devemos acrescentar ainda que essa particitação instaura uma cenografia diferente da instaurada pela legenda e para isso contribui a representação da gestualidade da personagem retratada. Como já mencionamos, na posição em que Clemente foi desenhado - pernas encolhidas, a capa como se estivesse sendo inflada pelo ar em movimento, ausência de linha horizontal representando um solo - ele poderia estar saltando, seria o instante em que está no alto. Isso também remete a um gesto muito comum em manifestações populares da Argentina, atendendo a um comando (el que no salte es... ), os manifestantes passam a saltar. O gesto pode ser observado tanto em atos políticos como nas torcidas de futebol. Assim, parece-nos que a cenografia enunciativa que se instaura mescla o esporte e política, fundindo dois aspectos muito representativos da personagem e de seu autor. Além disso, evoca também o papel simbólico que o personagem Clemente traz consigo como representante do torcedor da seleção argentina.

Como já afirmamos, Charaudeau (2006) entende o humor como uma estratégia discursiva pela qual (a) se constrói uma visão deslocada, inusitada, sobre qualquer aspecto da realidade, (b) seu produtor convida o interlocutor a compartilhar dessa visão, a entrar num jogo em que ele precisa encontrar a chave que lhe possibilitará jogar. Acreditamos, pelo exposto, que podemos dizer que o humor na tira se constrói mediante um jogo enunciativo paródico na relação com o interdiscurso das torcidas de futebol e das manifestações políticas. Além disso, há também algo de inusitado, de quebra de expectativa, pois em lugar de lamentar a perda do título, com a presença do personagem Clemente atualiza-se a alegria que marcou a os dois campeonatos mundiais ganhos pela seleção argentina. Dessa forma, interpretamos como o efeito possível para o humor a conivência lúdica. Por conseguinte, há também um ethos que se fusiona com o torcedor

${ }^{118}$ Entrevista realizada por e-mail com o autor em 02/07/2017 e reproduzida integralmente no Apêndice. 
argentino. Busca-se compartilhar com o destinatário a felicidade do título e o reconhecimento pelo esforço dos jogadores.

Nas tiras que veremos em seguida é justamente esse otimismo que é contestado. A primeira delas é uma publicação de autoria de Sendra, um exemplar da tira Yo, Matías que reproduzimos abaixo na figura 54.

\subsubsection{Yo, Matías - Vicecampeones}

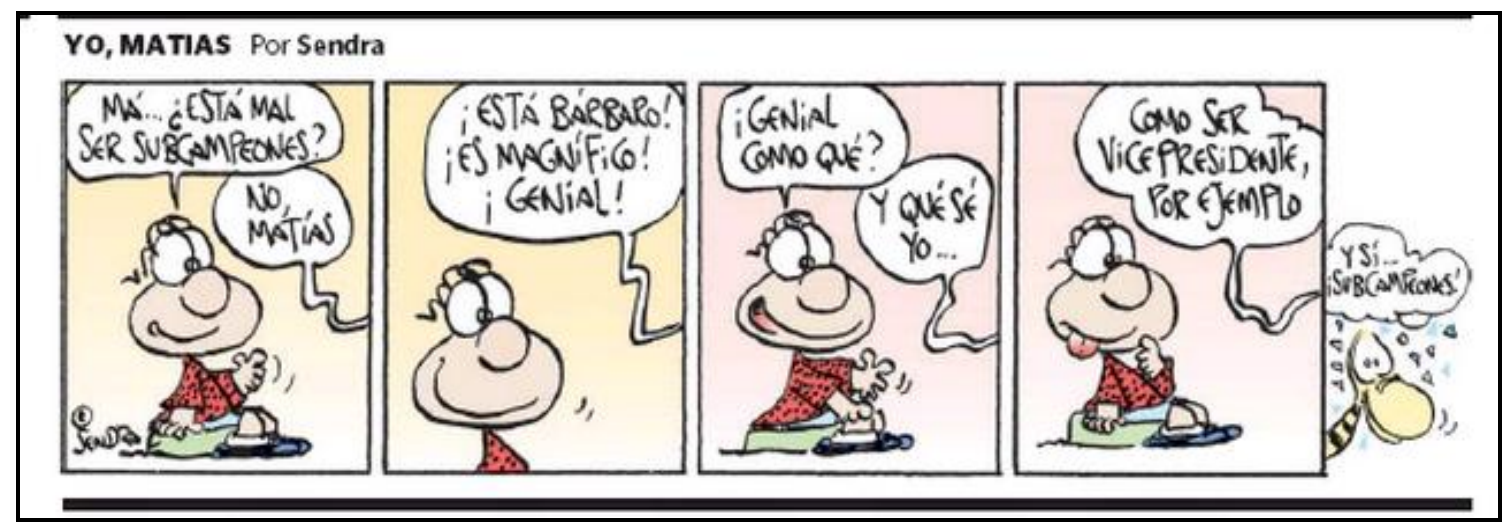

Figura 54- Yo Matías - Subcampeones - Fonte: Clarín de 14/07/14

Yo, Matías, tal como a maioria das produções que analisamos, é uma tira de personagem fixo, o garoto que dá nome à produção. Ele é o protagonista da maior parte delas, mas não é o único. Também às vezes aparecem sua tartaruga de estimação e umas baratinhas. A produção em análise é formada por quatro vinhetas; nelas vemos Matías sentado em uma espécie de pufe, conversando com alguém, que deduzimos ser a mãe, mas de quem só vemos o balão-fala que representa sua voz. A dedução é possível porque Matías se dirige a ela como $M a$ e também porque se trata de uma característica da tira: a mãe nunca aparece. Na segunda vinheta o enquadramento é um pouco mais aproximado ao rosto do personagem e na terceira, volta-se ao enquadramento da primeira. Nessas três primeiras vinhetas a expressão de Matías é praticamente a mesma: um misto de alegria ingênua e curiosidade. Sua expressão só mudará na terceira vinheta, quando se dará a virada que conclui a tira.

A cenografia que se instaura mediante os enunciados dos balões-fala é a de uma conversa entre mãe e filho. Na primeira vinheta, Matías como locutor-personagem se dirige à mãe e pergunta se está mal ser subcampeones. Nesse procedimento, pelo substantivo subcampeones também é delimitado o tema sobre o qual versará a tira e, 
consequentemente, o ato de humor que encerra. No balão-fala que representa a voz da mãe vemos que ela responde que não, ou seja, no está mal ser subcampeones. Na vinheta seguinte, seu balão-fala traz uma enumeração com vários adjetivos - está bárbaro, es magnífico, genial ser subcampeones - pelos quais reforça a qualificação positiva do vice-campeonato. Na terceira vinheta Matías solicita então uma comparação, procedimento que se encaixa no estereótipo do comportamento infantil. Crianças normalmente pedem comparações com experiências que fazem parte de seu universo de conhecimento para poder compreender algo. $\mathrm{O}$ enunciado de resposta da mãe mostra hesitação, dificuldade para encontrar o que o filho pede: y qué sé yo... Cria-se um suspense que se solucionará na última vinheta: ser subcampeones é genial como ser vicepresidente, por ejemplo. O rosto de Matías se altera, em lugar da alegria, parece expressar desagrado com a resposta. Ser vicepresidente não parece algo assim tão bom. $\mathrm{Na}$ lateral direita dessa vinheta, como que surgido dos bastidores do plano ficcional da cena entre Matías e sua mãe, vê-se o rosto do personagem Clemente, dirigindo-se ao leitor virtual, instalando assim outro plano de interação. Ele, como locutor-personagem enuncia: Y sí... iSubcampeones!, a modo de uma constatação com a qual é preciso se conformar. Como vemos, o efeito de sentido construído implicitamente é bem diferente daquele com o qual a tira começou. O procedimento para a construção do humor (cf. CHARAUDEAU, 2006) é um jogo enunciativo irônico: o que se diz (o sentido) é diferente daquilo que a materialidade linguística expressa, no caso, o subjacente é que ser subcampeones não é algo bom, porém não só porque o cargo de vice-presidente é, na maior parte das democracias, meramente representativo. Para a interpretação dessa tira, temos que fazer uma breve digressão, estabelecer um diálogo com o contexto político daquele momento e trazer à tona o papel que o jornal Clarín teve na correlação de forças desse campo.

O jornal faz parte do Grupo Clarín, o maior conglomerado de mídia do país. O governo de Cristina Kirchner, em um projeto de democratizar os meios de comunicação no país, aprovou uma lei pela qual se estabelecia um limite de concessão para os grupos que atuam no âmbito da comunicação. O Grupo Clarín foi fortemente atingido pela medida, teria de se desfazer de parte de seus ativos, e a contestou judicialmente. Ao longo dos dois mandatos de Cristina Kirchner, o grupo estabeleceu uma oposição ferrenha ao governo, usando os veículos do grupo como porta-vozes. Naquele momento, julho de 2014, o vice-presidente argentino Amado Boudou estava sendo processado devido a acusações de corrupção. Nas páginas do Clarín, ao longo do mês de julho, diariamente 
encontramos textos com um olhar negativo sobre o vice-presidente, ora reforçando os indícios de sua culpa, ora indicando que deveria renunciar. Pelo exposto, embora não possamos afirmar que na tira de Sendra tenha se operado um rebaixamento totalmente baseado no caso Boudou, é inegável que naquele momento, na Argentina, nas páginas do diário Clarín, o substantivo vicepresidente vinha marcado com todos as disputas que caracterizavam o campo político naquele momento.

Em nosso ponto de vista, portanto, o alvo do ato de humor que se constrói na tira pode ser o governo argentino naquele momento, que também encampou um olhar otimista sobre o vice-campeonato. O efeito possível, seguindo essa nossa linha de interpretação é o de conivência crítica. Nesse sentido, algo aparentemente inofensivo e ingênuo - a atitude de uma criança tentando interpretar o mundo - oculta uma crítica bastante forte sobre uma construção quase unânime a respeito da conquista do vicecampeonato pela seleção argentina. É possível também entender que o uso do personagem Clemente se dá em um procedimento de subversão, porque não encontramos nesse uso o torcedor fanático pela seleção argentina que o personagem de Caloi representava simbolicamente.

Em nossa interpretação, o ethos do emissor do ato de humor que a tira encerra é ambíguo. Por um lado, se alinha com a interpretação do vice-campeonato como uma conquista. Por outro, a posição crítica que traz para a cenografia um elemento polêmico do contexto político - o vice-presidente - questiona essa conquista. De qualquer forma, entendemos que se trata de um ethos que está identificado com a torcida e em relação simétrica com o leitor.

Chegamos à última tira a ser analisada. É outro exemplar de La Nelly, produção de Langer e Mirá e está reproduzida na figura 55. Como veremos, o olhar algo pessimista sobre o desempenho final da seleção também está presente neste caso. 


\subsubsection{La Nelly - Que bajón}

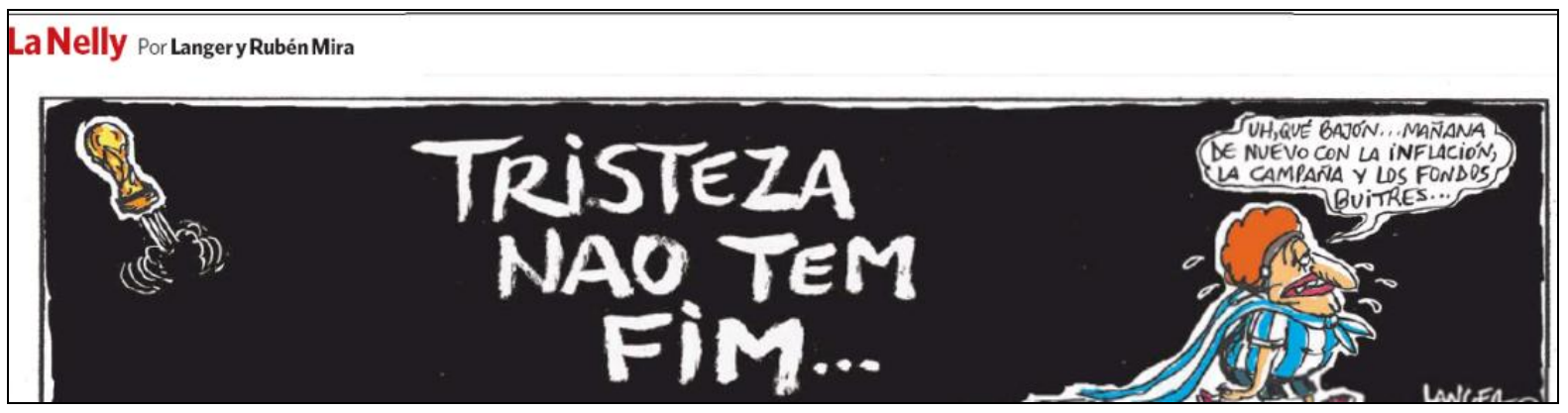

Figura 55- La Nelly - Bajón - Fonte: Clarín de 15/07/14

A tira tem uma só vinheta e foi publicada dois dias depois de encerrado o mundial. O fundo é todo preto e nele se lê, em grandes letras brancas Tristeza nao tem fim. Embora o não esteja sem o til, o enunciado está em português e se trata do primeiro verso da canção A Felicidade, composta por Tom Jobim e Vinícius de Moraes. No canto superior esquerdo vê-se a imagem da taça que é entregue como troféu aos campeões da Copa e dela sai uma coluna de fumaça, como se fosse um foguete decolando. Também vemos Nelly, a personagem está vestida com uma camiseta e uma capa com as cores da bandeira argentina. Na posição em que está desenhada é como se tivesse vindo caminhando do lado esquerdo da tira e assim segue, em direção ao lado direito. Seus olhos estão desenhados semicerrados, traz uma expressão de abatimento, há gotas que saem de seu rosto, como se fossem lágrimas

A imagem do troféu e as cores com que Nelly está vestida são as principais referências para circunscrever tematicamente a tira à Copa do Mundo. O fato de a Copa ser representada como um foguete que parte, o fundo preto da tira - simbolização de luto em boa parte dos países ocidentais, especialmente naqueles de forte influência cristã - e o verso da canção conferem elementos sobre o ponto de vista que será apresentado: a Copa foi perdida, há tristeza e luto por essa perda.

No balão-fala de Nelly lemos seu comentário a respeito: Uh, qué bajón... Mañana de nuevo con la inflación, la campaña y los fondos buitres... Visto que não há outro personagem na tira para uma interlocução no interior da cena ficcional, deduz-se que o leitor é o alocutário. A cenografia instaurada é a queixa sobre algum evento. O enunciado começa com uma interjeição e o substantivo bajón, referido a um momento de depressão infelicidade. O sufixo -ón no caso, tem um valor semântico de algo brusco e forte (cf. Manual da Nueva Gramática de la Lengua Española, p. 169), evidenciando-se a interrupção repentina da euforia esperançosa que antecedia a partida pela tristeza trazida 
com o resultado. O advérbio mañana ancora o que virá nos dias seguintes à situação de comunicação, ou seja, após o 15 de julho de 2014. Segue-se uma enumeração de fatos da realidade argentina: a inflação que voltava a subir, a campanha para a eleição que seria em 2015 e que já se desenhava e os fondos buitres, os ferozes fundos de capital de risco com os quais o governo estava negociando nos Estados Unidos naquele momento. Não há nenhum verbo no enunciado, a enumeração vai construindo uma sequência panorâmica descritiva de coisas negativas. Como vemos, tal como na tira de Caco Galhardo (figura 49) que analisamos quando abordamos as tiras publicadas na Folha de S. Paulo, temos também aqui um dos aspectos ritualísticos que envolvem a Copa do Mundo: a suspensão do tempo da realidade cotidiana. Por trinta dias, aqueles que acompanham o evento parecem entrar numa dimensão de tempo mítica, em que só os acontecimentos do rito importam: partidas, classificações, eliminações e, obviamente, torcer. O término da Copa - seja qual for o resultado - traz de volta o dia a dia. Como a seleção argentina não se sagrara campeã, seria preciso afrontar essa realidade sem o otimismo que o valor simbólico da conquista proporcionaria. Em nosso ponto de vista, busca-se instaurar na interlocução com o leitor virtual um tipo de cumplicidade a respeito do inevitável contato com a realidade. Como se a personagem - apesar de ficcional - tivesse também que passar pelo mesmo, o que não deixa de ter sua dose de verdade, posto que La Nelly como tira tematiza o tempo todo as notícias do cotidiano argentino.

Passando ao verso da canção reproduzido no fundo da tira, como podemos ver com ele se retoma a antítese alegria-tristeza bastante presente nos discursos que envolvem a rivalidade Argentina e Brasil no futebol e já abordada na análise da tira Diógenes y el Linyera. Por outro lado, o procedimento de intertextualidade pelo qual os versos se materializam nessa produção enseja trazer dados para complementar essa interpretação.

Conforme Lopes e Tatit (2008, passim) A Felicidade é um samba composto por Tom Jobim e Vinícius em 1959, para fazer parte do filme Orfeu do Carnaval, cuja trilha sonora fora encomendada aos dois pelo diretor francês Marcel Camus. O dado relevante para nosso trabalho é que na carreira internacional que Vinícius desenvolveu posteriormente, a canção integrou aquele que é considerado o disco de música brasileira mais vendido na Argentina. Trata-se de um disco gravado em um show realizado no café La Fusa em 1970, no qual Vinícius se apresentou ao lado de Toquinho e Maria Creuza. Segundo reportagem de Márcio Resende feita para a Rádio França Internacional, crianças e adolescentes argentinos nos anos 70, cresceram ouvindo o disco que os pais punham em casa. As melódicas canções eram absorvidas como cantigas de roda e garantiram a 
transcendência do disco através das seguintes gerações. O disco faz parte do movimento de divulgação e exportação da música brasileira para os países de língua espanhola no qual a indústria fonográfica investiu massivamente nos anos 70. Com as canções vinham também conteúdos - verbais e não verbais - que ajudariam a criar um imaginário sobre o Brasil. Como podemos ver, no caso do contato Argentina e Brasil, fenômenos da indústria cultural também acabam deixando marcas na discursividade de um país sobre o outro.

Há outro detalhe a respeito do disco citado que merece ser mencionado. A canção A Felicidade é a primeira, mas vem precedida de uma breve vinheta. Durante pouco mais de um minuto os artistas e a banda entoam as duas primeiras estrofes do tema A Copa do Mundo é nossa com o qual se celebrou a conquista do tricampeonato pelos brasileiros. Com os versos da canção estampados na tira, essa relação com o futebol é atualizada.

Ao evocar-se a tristeza da derrota com uma canção brasileira, a tira, como texto, faz um movimento interdiscursivo em que mais uma vez o Outro representado pelo Brasil se instala no discurso argentino sobre si. Esse gesto dialoga com algo apontado pelo pesquisador Gustavo Lins Ribeiro e retomado por Guedes (2002), o fato de que brasileiros e argentinos, em vários aspectos parecem estar irremediavelmente presos a um jogo especular entre si. De nossa parte acrescentamos que no caso de nosso trabalho só encontramos a presença do Brasil nas tiras publicadas na Argentina, não ocorrendo o movimento inverso, ou seja, não encontramos no conjunto de tiras publicadas na Folha de S. Paulo que analisamos nenhuma menção à Argentina ou à sua seleção. Vale dizer que essa constatação vale para todo o material que manuseamos ao longo da pesquisa.

Como procedimento para o humor identificamos traços que podemos classificar dentro dos recursos que Charaudeau denomina incoerência insólita: a taça voando, o fundo preto indicando luto, os versos da canção e mesmo a enumeração dos problemas que voltarão a fazer parte do dia a dia do leitor. Como possível efeito, nos parece que estaria a conivência lúdica, aquela em que o autor do ato de humor se coloca em uma posição de igualdade solidária com o destinatário, visto que não identificamos uma contra-argumentação. Nesse sentido, está a constatação de que o espaço-tempo do lúdico, do divertido se encerrou, e que é preciso afrontar o cotidiano sem a alegria efêmera que a conquista poderia ter proporcionado. Consequentemente, identificamos igualmente solidariedade e simetria no ethos tanto da personagem como locutor como do emissor do ato de humor que representa a tira. 


\subsubsection{A modo de retomada}

Focalizamos nesta última parte da análise as tiras publicadas no Clarín no intervalo entre 10 e 15 de julho de 2017, cujo tema era o seleção argentina na Copa de 2014 ou o próprio evento.

Para os nossos propósitos, os fatos mais relevantes na retomada da participação da Argentina na Copa foram a vitória sobre a Holanda na semifinal e o vice-campeonato frente à Alemanha. Vimos que na interpretação da mídia esportiva do país, apesar de a seleção ter sido derrotada na final os jogadores deram tudo de si e por isso foram recebidos como heróis pelo vice-campeonato. As manchetes nos jornais enfatizavam valores como dignidade, orgulho, valentia.

Em termos gerais, destacamos a presença explícita do Brasil - como o Outro - em três das tiras analisadas, com a mobilização tanto de elementos relacionados à rivalidade como de representações estereotípicas do país e seus habitantes para os argentinos. Nesse sentido, identificamos que a antítese alegria-tristeza é uma constante nos discursos a respeito da relação entre os dois países, dado que dialoga com estudos realizados em outras áreas das ciências humanas.

A relação entre futebol e política também aparece discursivamente nas tiras mediante particitações ou procedimentos enunciativos mais complexos, em que os implícitos envolvem conhecimento das disputas políticas que tinham lugar na Argentina naquele momento.

Também verificamos a presença de elementos de heroicidade e glória associados à participação da seleção argentina, em diálogo com outros textos e gêneros da imprensa escrita do país. Na produção analisada (Figura 52), por meio do enunciados dos locutores-

personagem, esses elementos aparecem tanto reforçados como contestados por procedimentos irônicos.

Resumimos nos quadros abaixo os procedimentos identificados para os atos de humor e seus possíveis efeitos. 


\begin{tabular}{|c|c|c|c|c|c|c|c|}
\hline \multirow{3}{*}{ Produção } & \multicolumn{7}{|c|}{ Procedimentos } \\
\hline & \multirow[b]{2}{*}{ 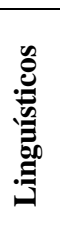 } & \multicolumn{6}{|c|}{ Discursivos } \\
\hline & & 总 & 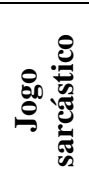 & 惫 & 递 & 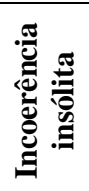 & 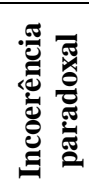 \\
\hline La Nelly - Súbditos (Figura 50) & & & $\mathbf{x}$ & & & & \\
\hline $\begin{array}{l}\text { Diógenes y el Linyera - La alegría es } \\
\text { argentina } \\
\text { (Figura 51) }\end{array}$ & & $\mathbf{x}$ & & & & & \\
\hline $\begin{array}{l}\text { Donatela - Hinchada histórica } \\
\text { (Figura 52) }\end{array}$ & & $\mathbf{x}$ & & & & & \\
\hline $\begin{array}{l}\text { Donatela - Bienvenidos héroes } \\
\text { (Figura 53) }\end{array}$ & & & & $\mathbf{x}$ & & & \\
\hline $\begin{array}{l}\text { Yo Matías - Subcampeones } \\
\text { (Figura 54) }\end{array}$ & & $\mathbf{x}$ & & & & & \\
\hline $\begin{array}{l}\text { La Nelly - Bajón } \\
\text { (Figura 55) }\end{array}$ & & & & & & $\mathbf{x}$ & \\
\hline
\end{tabular}

\begin{tabular}{|l|c|c|c|c|}
\hline \multirow{2}{*}{ Produção } & \multicolumn{3}{|c|}{ Efeitos possíveis } \\
\cline { 2 - 5 } & $\begin{array}{c}\text { Conivência } \\
\text { lúdica }\end{array}$ & $\begin{array}{c}\text { Conivência } \\
\text { crítica }\end{array}$ & $\begin{array}{c}\text { Conivência } \\
\text { cínica }\end{array}$ & $\begin{array}{c}\text { Conivência } \\
\text { de derrisão }\end{array}$ \\
\hline La Nelly - Súbditos (Figura 50) & & & & $\mathbf{x}$ \\
\hline $\begin{array}{l}\text { Diógenes y el Linyera - La alegría es } \\
\text { argentina (Figura 51) }\end{array}$ & & $\mathbf{x}$ & & \\
\hline Donatela - Hinchada histórica (Figura 52) & & $\mathbf{x}$ & & \\
\hline Donatela - Bienvenidos héroes (Figura 53) & $\mathbf{x}$ & & & \\
\hline $\begin{array}{l}\text { Yo Matías - Subcampeones } \\
\text { (Figura 54) }\end{array}$ & & $\mathbf{x}$ & & \\
\hline La Nelly - Bajón (Figura 55) & $\mathbf{x}$ & & & \\
\hline
\end{tabular}

Como vemos, conforme nossa análise os procedimentos que Charaudeau classifica como discursivos foram os mais mobilizados nesse conjunto de tiras analisado. $\mathrm{O}$ sarcasmo e o consequente possível efeito de derrisão foram identificados na tira que celebra a conquista da vaga para a final pela seleção argentina e seus alvos eram os holandeses e os brasileiros. Nas outras, a ironia revelou-se um procedimento muito frequente. Destacamos com isso o pouco uso de procedimentos de humor mais agressivos e com possíveis efeitos destruidores.

Em duas das três tiras que tratavam especificamente do vice-campeonato, identificamos como possível efeito a conivência lúdica, aquela em que segundo Charaudeau (2006) o emissor busca uma fusão emocional com o destinatário. Porém a 
visão sobre o título era diferente em cada uma delas, otimista em uma, pessimista na outra. A conivência crítica mostrou-se a mais frequente, um resultado consistente com os outros conjuntos de tiras analisados.

Por fim, destacamos também a presença do personagem Clemente desenhado por outros autores reafirmando a força simbólica do personagem identificado com o torcer pela seleção argentina. Na próxima seção, consideraremos de forma comparativa os resultados obtidos.

\section{Discussão comparativa dos resultados}

Retomamos que nosso objetivo, especificamente na análise das tiras selecionadas para investigar eventos das Copas de 1994 e 2014, era examiná-las enquanto gêneros discursivos para:

(i)

verificar que efeitos de sentido são construídos sobre as derrotas e as vitórias das seleções argentina e brasileira nas edições da Copa de 1994 e 2014;

(ii) analisar os procedimentos utilizados para obter o humor e seus possíveis efeitos,

(iii) observar que relações interdiscursivas se estabelecem com outros discursos da imprensa sobre o futebol ou a Copa nos respectivos países,

(iv) verificar os posicionamentos que a respeito desses temas se revelam,

(v) analisar as semelhanças e diferenças com relação aos pontos anteriores nas produções da Argentina e do Brasil.

Entendemos que os quatro primeiros objetivos foram contemplados e comentados ao longo deste capítulo, ao final de cada uma das seções que o compõem. Assim, nas linhas que seguem pretendemos alinhavar, em uma perspectiva comparativa, aspectos da análise que se relevaram segundo nosso ponto de vista. Nesse processo, estabeleceremos relações não só entre as conclusões que apontamos ao longo da análise das diferentes tiras, como também com reflexões surgidas durante o levantamento de dados desta pesquisa. Cabe recordar que nosso trabalho não tem expectativas de generalização, portanto a discussão dos dados será sempre circunscrita ao recorte que efetuamos para levar a cabo nosso estudo.

Começaremos retomando comparativamente os quadros em que sintetizamos os procedimentos encontrados para a construção do humor nas tiras analisadas, bem como 
seus efeitos possíveis. Em seguida abordaremos elementos das cenografias enunciativas das tiras. Terminaremos enfocando os sentidos construídos a respeito do futebol e da Copa do Mundo nas produções que analisamos dos dois países.

\subsection{Sobre o humor}

\subsubsection{Os procedimentos}

Nos quadros a seguir, apresentamos os resultados de nossa interpretação sobre a construção e o papel do humor nas tiras, seguindo as categorias propostas por Charaudeau (2006). Os dados estão consolidados e apresentados segundo os jornais de origem das tiras. Primeiramente abordaremos os procedimentos e na sequência, discutiremos os efeitos possíveis.

Lembramos que o autor afirma que o exame de um ato de comunicação humorístico em uma perspectiva discursiva deve contemplar a análise de sua (i) situação de comunicação, a (ii) temática predominante, os (iii) procedimentos linguageiros que são colocados em funcionamento e os (iv) efeitos possíveis nos destinatários. Com relação ao ponto (iii), Charaudeau (2006) divide os procedimentos em linguísticos e discursivos. Os primeiros dependem do mecanismo léxico-sintático-semântico e envolve a relação formasentido da língua. Os segundos envolvem mais diretamente os mecanismos de enunciação do ato humorístico. Charaudeau (2006) ainda os subdivide em enunciativos e lógico-semânticos. Nos enunciativos se encontram o jogo irônico, o sarcástico, o paródico. Os procedimentos lógico-semânticos envolvem, para a obtenção do humor, operações com o próprio valor semântico das palavras no interior do enunciado e jogam com a dissociação de isotopias. Charaudeau (2006) os subdivide em incoerência louca, incoerência insólita e incoerência paradoxal. 


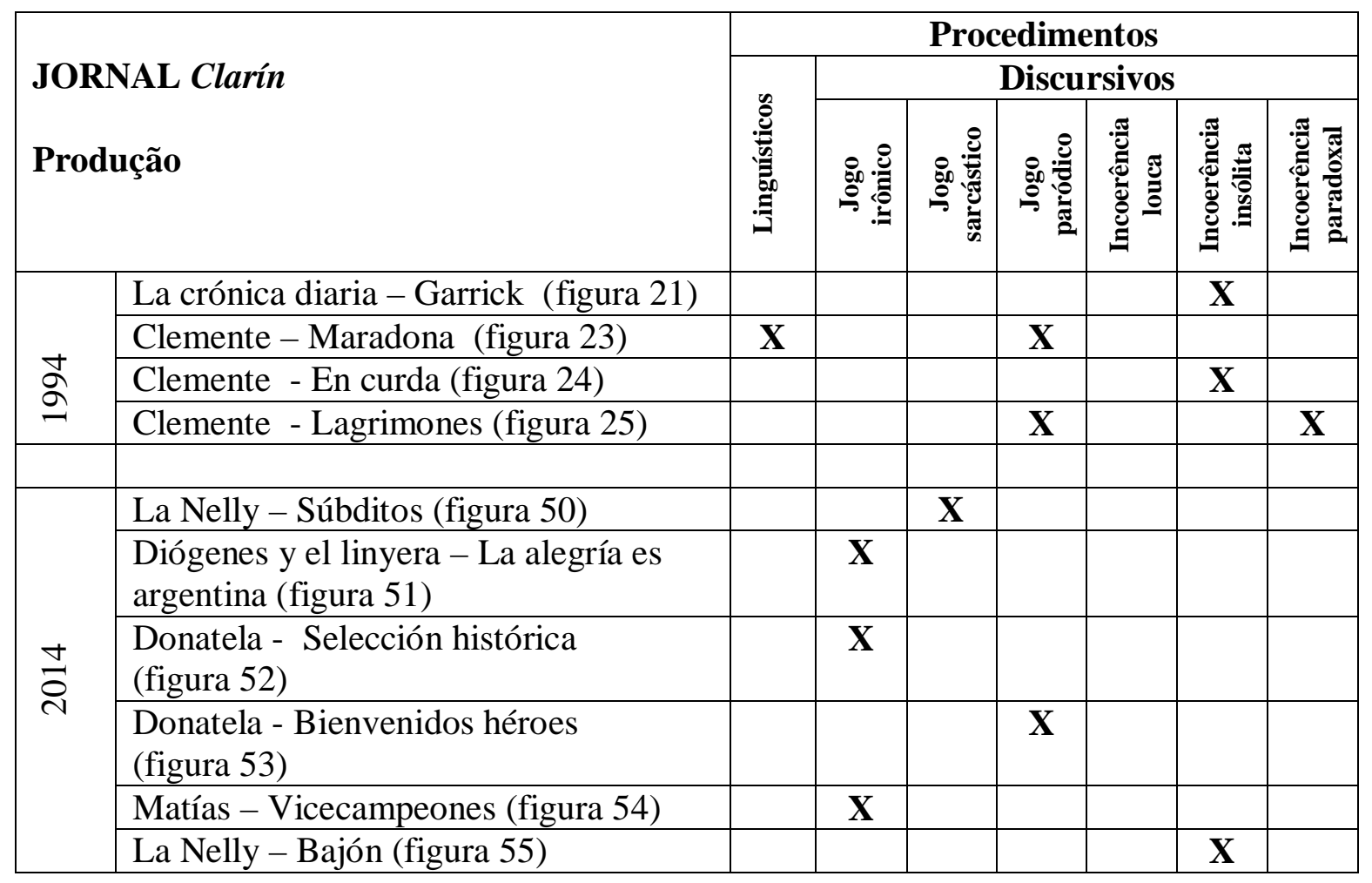

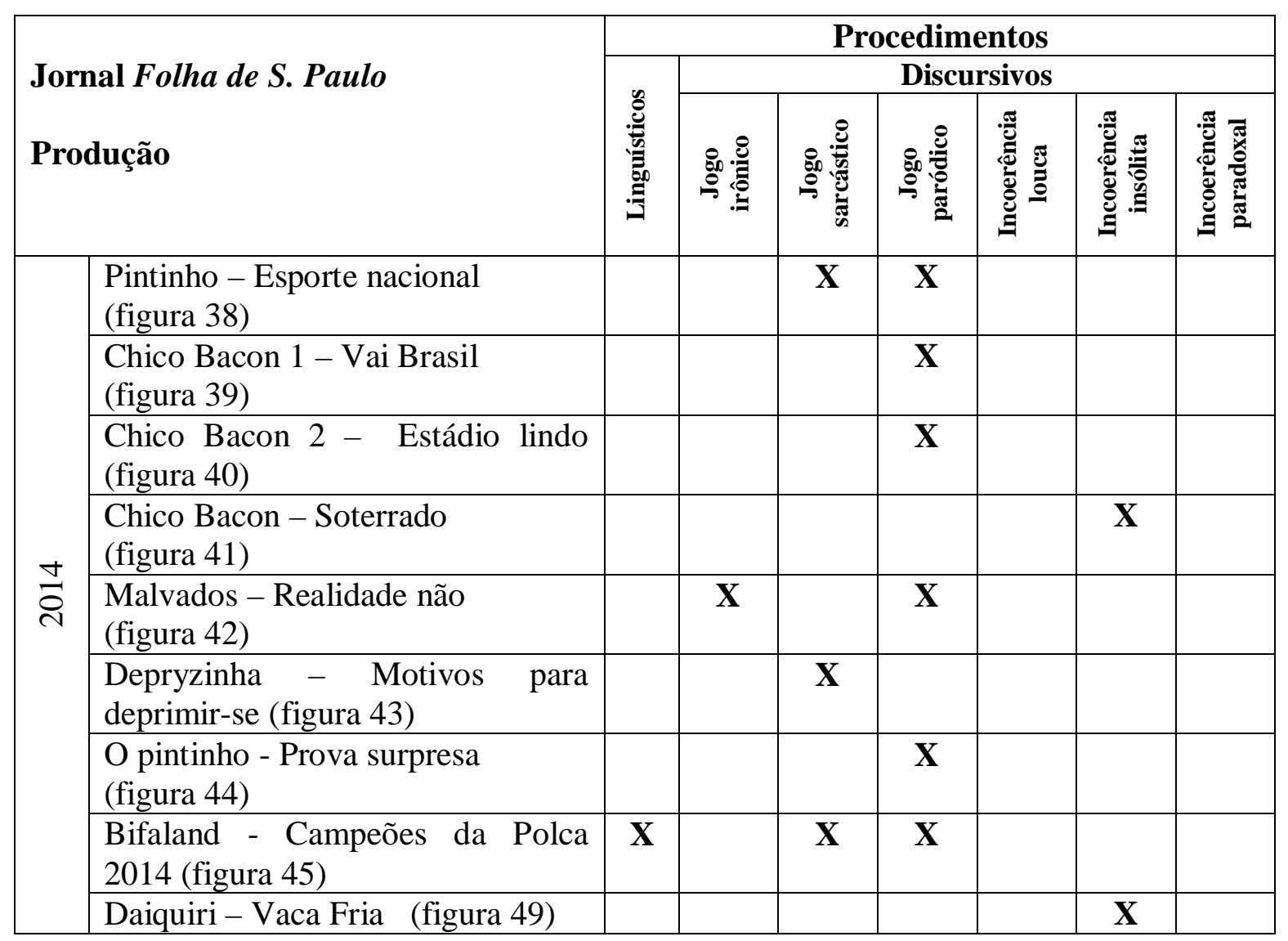


Verificamos uma situação bastante similar nos conjuntos que representam as produções de cada país quanto aos procedimentos utilizados. Em ambos, aqueles classificados por Charaudeau (2006) como discursivos foram mais frequentes que os linguísticos. Conforme o autor francês, os procedimentos discursivos jogam com a complexidade do mecanismo de enunciação, com posições ocupadas pelos envolvidos na interlocução (sujeito emissor e sujeito destinatário) e pelo alvo visado, com conhecimentos sobre o contexto sócio-histórico bem como com o valor social dos temas sobre os quais concerne o humor. São conhecimentos que projetam um leitor não só com bom nível de competência linguística, como também discursiva ${ }^{119}$. Portanto, o uso de procedimentos discursivos como recurso para o humor responde às características do público aos quais as tiras se destina, ou seja, adultos e leitores de jornal, portanto, com um bom grau de escolaridade.

No que concerne aos enunciativos, nos conjuntos que se referem à Copa de 2014, vemos que o sarcasmo como recurso para o humor foi mais usado nas tiras brasileiras que nas tiras argentinas. Há ainda outra diferença, os alvos. Na tira argentina Súbditos (figura 50), o objeto do sarcasmo eram os rivais, os holandeses e os brasileiros. Nas tiras brasileiras, os alvos eram os próprios brasileiros, no caso das tiras Esporte nacional (figura 38) e Motivos para deprimir-se (figura 43). No caso da tira Campeões da Polca 2014 (figura 45), os alvos eram jogadores da seleção brasileira e outras torcidas, a nosso ver, escolhidas aleatoriamente. Uma primeira explicação para esse dado, a nosso ver, diz respeito ao estilo dos autores e das autoras cujas produções figuram no conjunto que corresponde às tiras brasileiras publicadas em 2014 em nosso corpus. O sarcasmo é uma marca muito característica do estilo de Allan Sieber e André Dahmer, e também está presente nas produções de Priscyla Vieira e Alexandra Moraes. No conjunto de quadrinistas que publicavam na Folha em 2014, os quatro fazem parte de uma geração mais nova na comparação com autores como Angeli, Laerte e Caco Galhardo. Por outro lado, nos parece possível interpretar que esse traço, ou seja, maior presença de um humor mais agressivo para abordar os resultados da seleção brasileira na Copa de 2014, dialoga com a animosidade do contexto em que ela se deu e com a própria relação que se estabeleceu entre a seleção e os brasileiros em geral após o resultado de 7 a 1 para a Alemanha: a seleção foi vaiada em mais de uma ocasião após o acontecimento.

${ }^{119}$ Conforme Charaudeau (2001) a competência discursiva exige que todo sujeito que se comunica e interpreta tenha capacidade de manipular (Eu)-reconhecer $(\mathrm{Tu})$ os procedimentos de encenação discursiva que respondem às necessidades da condição situacional, bem como saberes referentes a conhecimentos e crenças compartilhados. 


\subsubsection{Os efeitos possíveis}

Recordamos que Charaudeau (2006) entende os efeitos possíveis de um ato de humor como resultante da relação entre o tipo de questionamento sobre o mundo que o ato realiza e o tipo de conivência que o emissor propõe para o destinatário. A partir desse raciocínio, o autor elenca quatro possíveis efeitos: a conivência lúdica, a crítica, a cínica e a de derrisão.

Resumimos nos quadros abaixo nossa interpretação para os efeitos possíveis nas tiras analisadas segundo a proposta do autor francês.

\begin{tabular}{|c|c|c|c|c|c|}
\hline \multirow{2}{*}{\multicolumn{2}{|c|}{$\begin{array}{l}\text { JORNAL CLARÍN } \\
\text { Produção }\end{array}$}} & \multicolumn{4}{|c|}{ Efeitos possíveis do humor } \\
\hline & & \multirow{2}{*}{$\begin{array}{c}\begin{array}{c}\text { Conivência } \\
\text { lúdica }\end{array} \\
\mathbf{x} \\
\end{array}$} & \multirow{2}{*}{$\begin{array}{c}\text { Conivência } \\
\text { crítica }\end{array}$} & \multirow[t]{2}{*}{$\begin{array}{l}\text { Conivência } \\
\text { cínica }\end{array}$} & \multirow[t]{2}{*}{$\begin{array}{l}\text { Conivência } \\
\text { de derrisão }\end{array}$} \\
\hline \multirow{4}{*}{ बे } & La crónica diaria - Garrick (figura 21) & & & & \\
\hline & $\begin{array}{l}\text { Clemente - Maradona } \\
\text { (figura 23) }\end{array}$ & & $\mathbf{x}$ & & \\
\hline & Clemente - En curda (figura 24) & $\mathbf{x}$ & & & \\
\hline & $\begin{array}{l}\text { Clemente - Lagrimones } \\
\text { (figura 25) }\end{array}$ & $\mathbf{x}$ & & & \\
\hline & & & & & \\
\hline \multirow{6}{*}{$\stackrel{\searrow}{\circlearrowright}$} & $\begin{array}{l}\text { La Nelly - Súbditos } \\
\text { (figura 50) }\end{array}$ & & & & $\mathbf{x}$ \\
\hline & $\begin{array}{l}\text { Diógenes y el linyera - La alegría es } \\
\text { argentina (figura 51) }\end{array}$ & & $\mathbf{x}$ & & \\
\hline & $\begin{array}{l}\begin{array}{l}\text { Donatela - Hinchada histórica } \\
\text { (figura 52) }\end{array} \\
\text { - }\end{array}$ & & $\mathbf{x}$ & & \\
\hline & $\begin{array}{l}\begin{array}{l}\text { Donatela - Bienvenidos héroes } \\
\text { (figura 53) }\end{array} \\
\end{array}$ & $\mathbf{x}$ & & & \\
\hline & $\begin{array}{l}\text { Matías - Vicecampeones } \\
\text { (figura 54) }\end{array}$ & & $\mathbf{x}$ & & \\
\hline & La Nelly - Bajón (figura 55) & $\mathbf{x}$ & & & \\
\hline
\end{tabular}




\begin{tabular}{|l|l|c|c|c|}
\hline \multirow{2}{*}{ Jornal Folha de S. Paulo } & \multicolumn{3}{|c|}{ Efeitos possíveis } \\
\cline { 2 - 5 } Produção & $\begin{array}{c}\text { Conivência } \\
\text { lúdica }\end{array}$ & $\begin{array}{c}\text { Conivência } \\
\text { crítica }\end{array}$ & $\begin{array}{c}\text { Conivência } \\
\text { cínica }\end{array}$ & $\begin{array}{c}\text { Conivência } \\
\text { de } \\
\text { derrisão }\end{array}$ \\
\hline & $\begin{array}{l}\text { Pintinho - Esporte nacional } \\
\text { (figura 38) }\end{array}$ & $\mathbf{x}$ & & \\
\hline $\begin{array}{l}\text { Chico Bacon 1 - Vai Brasil } \\
\text { (figura 39) }\end{array}$ & $\begin{array}{l}\text { Chico Bacon 2 - Estádio lindo } \\
\text { (figura 40) }\end{array}$ & $\mathbf{x}$ & & \\
\hline $\begin{array}{l}\text { Chico Bacon - Soterrado } \\
\text { (figura 41) }\end{array}$ & $\begin{array}{l}\text { Malvados - Realidade não } \\
\text { (figura 42) }\end{array}$ & $\mathbf{x}$ & & \\
\hline $\begin{array}{l}\text { Depryzinha - Motivos para deprimir-se } \\
\text { (figura 43) }\end{array}$ & & $\mathbf{x}$ & & \\
\hline $\begin{array}{l}\text { O Pintinho - Prova surpresa } \\
\text { (figura 44) }\end{array}$ & & $\mathbf{x}$ & $\mathbf{x}$ & $\mathbf{x}$ \\
\hline $\begin{array}{l}\text { Bifaland - Campeões da Polca 2014 } \\
\text { (figura 45) }\end{array}$ & & $\mathbf{x}$ & & \\
\hline Daiquiri - Vaca Fria (figura 49) & & & \\
\hline
\end{tabular}

No conjunto de tiras argentinas referentes à Copa de 1994, constatamos que a conivência lúdica foi a mais encontrada. Segundo Charaudeau (2006), na conivência lúdica o emissor do ato de humor procura uma fusão emocional com o destinatário, compartilhar um olhar distanciado sobre as vicissitudes da existência. Assim, relacionamos esse dado ao tema abordado, visto que se tratavam de tiras que glosavam o impacto emocional dos acontecimentos envolvendo Maradona e a própria eliminação da seleção. Nesse sentido, identificamos nesses casos traços de solidariedade e simetria para o ethos discursivo dos emissores dos atos humorísticos, que se igualam aos torcedores argentinos na tristeza sentida por causa dos eventos, sem nenhum julgamento a respeito de responsáveis. Tampouco encontramos efeitos de sentidos que desqualificassem esse impacto emocional dos acontecimentos que as tiras tematizavam, ou seja, uma visão crítica a respeito de como a população poderia se sentir em razão da frustrada participação da seleção argentina na Copa, de desqualificação do sentimento, por exemplo.

Já no conjunto das tiras referentes à Copa de 2014, tanto do Clarín como da Folha de S. Paulo, em nossa análise observamos que a conivência crítica prevaleceu como possível efeito nas tiras dos dois países, embora não tenha sido a única. É preciso ter em 
conta que tínhamos nesse subconjunto do corpus um número maior de autores, tanto brasileiros como argentinos. Consequentemente, tínhamos também diferentes estilos autorais, diversidade de pontos de vista.

No que se refere especificamente às tiras brasileiras analisadas sobre a Copa de 2014, lembremos que uma parte delas tematizava as situações de conflito que vivíamos no campo social e político, e a outra parte, o mal desempenho da seleção. Naquelas que tinham como tema a participação da seleção, em uma única identificamos a conivência lúdica (Chico Bacon - Soterrado - Figura 41) e, por conseguinte, um ethos solidário e em posição de igualdade para com o destinatário, os possíveis torcedores brasileiros anonadados pela derrota de 7 a 1 para a Alemanha. Nas outras, identificamos nos ethos de seus emissores traços de superioridade intelectual e distanciamento emocional com relação aos acontecimentos envolvendo a seleção na Copa.

A criticidade corrobora o fato de que o humor muitas vezes propõe contraargumentos para as situações que tematiza, questionando a doxa e construindo novas perspectivas. Por outro lado, a comparação dos resultados que encontramos na análise das produções brasileiras e argentinas quanto ao uso do humor, seus efeitos possíveis e os ethé construídos pelos procedimentos evidenciam nas produções brasileiras tensões mais fortes com relação ao impacto dos acontecimentos da Copa do Mundo e, por conseguinte, sobre o futebol na sociedade brasileira. Nas produções argentinas, não identificamos as problematizações envolvendo o futebol e a realidade nacional que estavam presentes nas tiras brasileiras. Esse dado será retomado no último item a ser abordado em nossa discussão, a saber, os sentidos construídos a respeito do futebol e da Copa.

\subsection{Sobre as cenografias}

Recordemos que Maingueneau $(2001,2010)$ define a cenografia como a cena instituída pelo próprio discurso, aquela em que o leitor se vê envolvido e interpelado. A cenografia de um texto pode convocar cenas compartilhadas pelo universo de saber do público ao qual se destina - as cenas validadas - que, como mencionamos no capítulo da Fundamentação Teórica, entendemos como relacionadas aos estereótipos. O autor compara a cenografia à inscrição de um círculo que instaura e valida o enunciador, o coenunciador, o lugar (topografia) e o momento (cronografia) a partir dos quais uma enunciação se desenvolve. 


\subsubsection{O leitor explicitamente convocado}

As tiras cômicas constituem um gênero discursivo que permite a instituição de um sem fim de cenografias. No universo ficcional que se desenvolve entre suas quatro retas é possível emular os mais diversos acontecimentos e convocar o leitor em diferentes papéis. $\mathrm{Na}$ comparação entre as produções dos dois países com os quais trabalhamos, o recurso de convocar explicitamente o leitor como alocutário esteve mais presente nas produções argentinas. Trata-se de um procedimento que apaga a fronteira entre o ficcional e nãoficcional, o personagem "conversa" com o leitor como se não fosse fictício. Esse dado talvez dialogue com a forte presença das tiras cômicas no cotidiano dos argentinos, tornando-se inclusive elemento tangível da paisagem de Buenos Aires por meio do Paseo de la Historieta ${ }^{120}$.

\subsection{3 "Nosotros" e "o Brasil"}

Entendemos que as formas pronominais desempenham um papel fundamental na construção das cenografias. Com relação a esse ponto, comparando as produções brasileiras e argentinas, observamos uma diferença quanto àquelas usadas pelos personagens, enquanto locutores, em enunciados sobre os acontecimentos envolvendo as seleções na Copa do Mundo.

Nas tiras argentinas, verificamos maior frequência do uso das formas do paradigma de primeira pessoa plural como agentes ou beneficiários de eventos que tinham lugar nos campeonatos, como podemos ver abaixo:

Vamos! Ahora, eh! (Figura 23)

Con todo lo que nos pasó, si yegamos a ganar hoy... (Figura 24)

Hoy es un día histórico para una selección que está haciendo historia y que sale a traernos la gloria. (figura 52)

Diógenes, ¡vamos a jugar la final! (Figura 51)

$\mathrm{Na}$ análise, esses pronomes foram interpretados como índices de inclusão, num procedimento em que o locutor-personagem se identificava com os torcedores ou com a população do país, ou seja, o referente dessa primeira pessoa plural seria a abstração que

${ }^{120}$ Ver capítulo 4. 
representa o Estado-nação Argentina, o país como construção geopolítica e seus habitantes.

Já nas tiras brasileiras de 2014, na maioria das tiras os locutores-personagens usam a terceira pessoa - o nome do país - para referir-se ao mesmo tipo de evento ou para falar do país:

\section{Vai Brasil! (Figura 39)}

Que número poderia ser pior para o Brasil? (Figura 42)

Sei que você contava com a vitória do Brasil para alegrar-se... (Figura 43)

O Brasil perdeu a Copa, mas o que o país ganhou? (Figura 44)

A única exceção é a personagem Depryzinha, que em referência aos problemas brasileiros usa "nossa educação nota zero". A mesma diferença, ou seja o uso mais frequente da primeira pessoa plural nas tiras argentinas e da terceira nas tiras brasileira, se repete se incluirmos na observação as produções que foram citadas mas não analisadas em detalhes.

Ressaltando os limites de nossa análise para generalizações, não podemos deixar de notar que comparativamente esses dados nos levam a concluir que nas tiras argentinas encontramos marcas de pertencimento e inclusão, enquanto que nas tiras brasileiras a perspectiva sobre os acontecimentos envolvendo a seleção é externa e não inclusiva. No que se refere à Copa de 2014, parece-nos que essa diferença poderia se explicar tendo em vista o desempenho desigual das respectivas seleções. Como mencionamos na análise, a construção discursiva a respeito da derrota do Brasil envolveu os termos vexame, vergonha e redundou em uma rejeição grande por parte dos torcedores. Já no caso da Argentina, a participação foi bem avaliada.

Porém, se nos aprofundarmos um pouco mais, acreditamos que podemos relacionar esses dados a conclusões apontadas por outras pesquisas que trabalharam comparativamente as discursividades dos dois países e, inclusive, no mesmo âmbito. Russo (2013) em pesquisa de mestrado em que analisou narrações de gols por locutores esportivos argentinos e brasileiros, identificou nos enunciados dos primeiros a representação de uma interpelação mais próxima: "a voz que emana deste ethos, cujo tom é mais exortativo ou crítico, estimularia ou promoveria uma resposta, tal como aconteceria numa situação de diálogo face a face" (RUSSO, 2013, p. 100). Por outro lado, nos enunciados do corpus brasileiro, Russo identificou uma enunciação mais distanciada tanto com relação aos eventos narrados como com relação aos interlocutores. Além disso, o pesquisador aponta uma posição hierarquicamente superior por parte dos locutores 
brasileiros. Como vemos, são conclusões similares às nossas, inclusão e igualdade nos locutores das tiras argentinas e perspectiva externa e não inclusiva no caso dos locutores brasileiros.

\subsubsection{Particitações e hiperenunciadores}

No capítulo em que trouxemos o arcabouço teórico que fundamenta nosso trabalho, resenhamos o conceito de particitação e hiperenunciador propostos por Maingueneau (2001, 2010). O autor desenvolve o conceito de particitação fundindo as palavras citação e participação para referir-se a citações de uma categoria especial, cujas características mencionamos no capítulo referido. As particitações, por sua vez, implicam um hiperenunciador, cuja autoridade, mais do que a verdade de um enunciado, garantirá sua validade, sua adequação e compromisso com valores e fundamentos de uma coletividade.

Tendo em vista o tema com que trabalhamos, esperávamos encontrar no universo ficcional das tiras reproduções de cantos ou gritos de torcida como particitações, com os correspondentes hiperenunciadores representando coletivos. Efetivamente foi o que aconteceu nos dois subconjuntos que compõem o corpus referente à Copa de 2014. No entanto, em nossos exemplos, tanto nas tiras brasileiras como argentinas, identificamos nas particitações e nos correspondentes hiperenunciadores traços que os vinculam tanto ao futebol (cantos de torcida) como à política (particitações militantes), como pudemos observar nas análises que efetuamos das produções reproduzidas nas figuras 38, 39, 50. Entendemos esse dado como uma manifestação do entrelaçamento entre futebol e política verificado nos eventos da Copa do Mundo. No Brasil, como vimos no item 2.1.2, a realização da Copa seguindo os moldes dos megaeventos esportivos da Fifa parece ter funcionado como parte do estopim que fez eclodir conflitos que estavam latentes, cisões que estavam apenas silenciadas, exacerbando o tom das disputas na correlação de forças políticas e sobre as quais já refletimos na análise sobre o contexto entre junho de 2013 e julho de 2014.

A Argentina, por sua vez, em 2014 também enfrentava uma forte tensão no campo político. Nesse sentido, identificamos que havia certa semelhança entre os dois países no acirramento das disputas, o que não significa que igualemos os dois contextos, cujas características respondem a configurações bem distintas em cada um deles. Entre as especificidades, está o fato de que, diferentemente do Brasil, o kirchnerismo enfrentou 
abertamente os interesses da oligarquia econômica desde o início. Dessa forma, a disputa em lugar de silenciada foi explicitada praticamente ao longo dos doze anos (2003 a 2015) dos governos de Néstor e Cristina Kirchner, em especial com os grupos hegemônicos de comunicação. No que tange ao futebol, especificamente, o Estado argentino adquiriu os direitos de exclusividade de transmissão da Copa que antes eram de uma emissora do grupo Clarín, que como já vimos, é um desses grupos.

Considerando o exposto, mediante as particitações e os hiperenunciadores que encontramos, podemos afirmar que o espaço discursivo das páginas dos jornais em que foram publicadas as tiras que analisamos acaba se configurando como um espaço para manifestações de alinhamento ou crítica às posições políticas presentes na exterioridade sócio-histórica.

\subsection{Sobre futebol, Copa do Mundo, brasileiros e argentinos}

\subsubsection{A Copa como suspensão do tempo}

Tanto no conjunto brasileiro como no argentino, encontramos produções em que se tematizava o aspecto ritualístico da Copa e a consequente suspensão simbólica do tempo. Analisando comparativamente as duas produções (figuras 49 e 55), destacamos que imageticamente, na tira de Caco Galhardo o personagem é representado em situação de imobilidade e acompanhado de uma expressão popular - de volta à vaca fria -, uma particitação que instaura um hiperenunciador vinculado à sabedoria popular que enuncia a inexorável retomada. Na produção de Mirá e Langer, a personagem Nelly é representada em movimento e verbaliza o que implica o encerramento na Copa. Enumera uma série de temas econômicos e políticos que dominavam o noticiário da Argentina naquele momento. Vários dados da tira de Galhardo nos levaram a vê-la como autorreferencial, o autor representando o ofício do próprio quadrinista. Já na produção La Nelly, seus autores tematizam a própria personagem na retomada, colocando-a em contato com dados da exterioridade não-ficcional e esmaecendo a fronteira entre ambos os planos.

Parece-nos que podemos estabelecer um paralelo entre essas tiras e certas características que observamos de forma geral nas produções brasileiras e argentinas. Ressalvamos que nossa interpretação se baseia em fatos que observamos ao longo dos praticamente cinco anos em que vimos tendo contato com as tiras publicadas diariamente em ambos os jornais e não só no material que analisamos. Especificamente no que se 
refere ao período de junho de 1994 até maio de 2014, notamos que uma das principais diferenças entre as tiras publicadas na Folha de S. Paulo e aquelas publicadas no Clarín é que no jornal argentino havia uma maior incidência de produções que dialogavam com temas do noticiário cotidiano. No jornal brasileiro, por outro lado, observamos que o humor nas produções se construía a partir de situações criadas pelas características dos personagens, vinculadas às relações interpessoais, à crônica de costumes, aos tipos humanos presentes numa grande metrópole como São Paulo. Nesse sentido, a forma como estão representados a personagem La Nelly e o personagem da tira de Caco Galhardo convergem com essas características gerais que observamos nas produções de ambos os países.

\subsubsection{O Brasil e o jogo bonito}

Talvez uma das representações mais fortemente arraigadas no que concerne à construção da identidade brasileira diz respeito a sermos o país do futebol e do "jogo bonito". Esse aspecto também foi comentado oportunamente no capítulo que dedicamos ao futebol como marca identitária do Brasil e da Argentina. No material que analisamos, encontramos referências a esse estereótipo nas tiras protagonizadas pelo personagem Clemente publicadas no Clarín em 1994. No Brasil, naquele momento, a seleção tetracampeã - também como já citado - enfrentava rejeição e descrédito justamente porque a população não via no estilo tático da equipe o jogo bonito que tradicionalmente foi associado à seleção brasileira.

\subsubsection{A rivalidade}

Considerando o recorte com o qual trabalhamos - a Copa do Mundo de Futebol e relação Brasil-Argentina - , esperávamos encontrar a rivalidade futebolística entre os dois países presente nas tiras publicadas nos jornais Clarin e Folha de S. Paulo ao longo do período das duas edições que selecionamos. A expectativa se confirmou somente com relação àquelas publicadas no Clarín, nas quais encontramos menção expressa ou referências ao país.

No caso das produções que se referem à Copa de 1994, o país é mencionado em tiras do personagem Clemente, que, como sabemos, nas edições das Copas protagonizava narrativas relacionadas aos acontecimentos do evento. Assim, como o Brasil ganhou a 
Copa, era esperado que o autor colocasse o personagem comentando o fato. Como apontamos sobre a tira reproduzida na figura 36, a conquista do Brasil é desqualificada pelo personagem enquanto locutor, pois o Brasil teria jogado como os italianos.

Passando à Copa de 2014, como já comentamos, para a torcida argentina, sua seleção ganhar a Copa em terras brasileiras conferiria um valor especial ao título. A esse respeito, Alabarces (2015, p. 111) afirma que para os torcedores a ocupação do território brasileiro "se transformará en la afirmación central de la acción de los hinchas argentinos a lo largo de toda la Copa ${ }^{121 "}$. Esse objetivo esteve reiterado em diferentes ações. Uma delas pouco antes do campeonato propriamente dito, na divulgação da canção que se converteu em seu hino em 2014, cujos dois primeiros versos dizem Brasil, decíme qué se siente / Tener en casa a tu papá. O mesmo autor acrescenta que esses versos "condensan el eje de interpretación: una hinchada 'visitante' que afirma haber ocupado el territorio ("en casa") del adversario, hinchada que a la vez funciona como "padre" simbólico". Ainda segundo Alabarces (p.101), os torcedores também trouxeram para o Brasil ações que as torcidas dos clubes argentinos levam a cabo em seu país. Uma delas é o chamado "banderazo", uma mobilização de rua com presença massiva de bandeiras com as cores do clube que marca a ocupação de um território. Entre junho e julho, ao menos em duas ocasiões no Rio de Janeiro houve manifestações desse tipo. O autor conclui (p.111) que "era central la ocupación del espacio público, como modo de marcar la condición "invasiva" de los hinchas: ocupaban, reitero, territorio ajeno, pero para colmo territorio brasileño, el gran rival según la mitología futbolera". Nesse sentido, as referências ao Brasil nas tiras do Clarín, espaço discursivo que delimitamos para nossa pesquisa, não deixam de lembrar essa presença de si (a Argentina) no território do Outro. Evidenciam, ademais, o peso simbólico que a Copa ter se realizado no Brasil teve no campo discursivo do futebol na Argentina. No âmbito das representações simbólicas, o fato de a balança estar mais favorável para o lado brasileiro no que se refere aos títulos talvez também deva ser considerado nessa necessidade manifesta de explicitar a alteridade.

Por outro lado, ao menos no que diz respeito ao espaço discursivo que circunscrevemos com nossa análise, a página de Quadrinhos da Ilustrada, os autores brasileiros das tiras com que trabalhamos parecem não ver a rivalidade como um tema relevante a ser explorado. Para ilustrar nosso ponto de vista, recorremos à entrevista que realizamos com o quadrinista Caco Galhardo. Indagado a respeito da ausência de tiras na

\footnotetext{
${ }^{121}$ De fato, em números, os argentinos representaram o maior contingente de sul-americanos que estiveram no Brasil durante a Copa.
} 
Folha de S. Paulo tematizando a rivalidade, o autor elencou algumas razões. A primeira delas o fato de que desde a Copa de 1990, Brasil e Argentina não tenham se enfrentado em uma Copa. Em segundo lugar, citou um posicionamento pessoal e comentou uma experiência, em que havia participado de um encontro de quadrinistas em Quito e no qual

todos chegavam, se encontravam e de imediato falavam sobre as bandas que estavam ouvindo. Todo mundo conhecia as mesmas bandas, todo mundo conhecia os mesmos escritores, os mesmos desenhistas, e eu brasileiro parecia um ignorante, porque a gente aqui no Brasil tem um distanciamento tão grande dos nossos irmãos latinos que são tão legais, a moçada do Equador, a moçada da Argentina. Todos eles, a gente é o mesmo povo da América Latina, a gente tem essa diferença da língua, o português, mas assim em termos de cultura, de consumo da cultura eles tão totalmente alinhados e a gente tá fora, a gente tá fechado no nosso mundo aqui do Brasil e olhando pros Estados Unidos. A gente não sabe quase nada, muito pouco, esse intercâmbio nosso é muito precário, então no meu discurso eu prefiro não dar vazão pra essa rixa, eu prefiro falar de outra forma, no futebol é claro que vira piada, mas eu pessoalmente, acho que a gente tinha que adotar um discurso totalmente diferente da rixa.

Por fim, citou também o tipo de publicação para a qual suas tiras se destinavam, levantando a hipótese de que em publicações mais especializadas em futebol como o Lance, que deve ter um cartunista ali que só faz charge de futebol, esse cara deve explorar muito esse ponto. Como vemos, Galhardo cita razões de duas ordens: uma mais subjetiva e outra relacionada ao meio em que o gênero é veiculado. Na primeira, estariam os aspectos da relação existente entre ele como autor e como ser do mundo e que incidem em suas criações. Na segunda, o fato de suas criações destinarem-se a uma página dentro do caderno de cultura de um jornal diário, e não de um jornal especializado em futebol, em que talvez a rivalidade pudesse ser um aspecto mais relevante para ser explorado. A segunda razão apontada por Galhardo nos leva a hipotetizar sobre as especificidades existentes em cada país na relação entre os espaços e os campos discursivos que delimitamos, a saber, a página de humor de um jornal diário e o futebol. Eventualmente, o fato de as tiras da Folha de S. Paulo que analisamos terem sido publicadas dentro do caderno de cultura, e as consequências disso para as características do público leitor, seja uma razão para não vermos explorada explicitamente a rivalidade com a Argentina. 


\subsubsection{Torcer ou não torcer?}

No material analisado que se refere ao Brasil em 2014, identificamos posicionamentos em que a repercussão do resultado da participação da seleção na Copa era colocada em relação polêmica com fatos da realidade brasileira, aspecto que foi oportunamente comentado. Nas tiras argentinas, por outro lado, não encontramos manifestações de que houvesse essa relação polêmica, ou seja, que o envolvimento com o futebol ofuscaria a consciência da realidade do país. Isso não significa não haver envolvimento emocional com a participação da seleção do país no campeonato. Como vimos pela análise das tiras publicadas no Clarín em 1994, o impacto emocional da eliminação da seleção argentina foi sentido com traços de melodrama.

Retomamos aqui também o dado a respeito das características dos ethé dos emissores das tiras. Quando tomamos a totalidade de nosso trabalho - não só a Copa de 1994, vemos os ethé dos emissores das tiras argentinas em relação mais simétrica e mais amalgamada com a população do país no que diz respeito ao futebol. Encontramos várias produções em que os personagens locutores se assimilavam com a seleção e com o país. Por outro lado, no lado brasileiro, somente nas produções de um autor - Caco Galhardo identificamos um ethos alinhado com o torcedor.

Nossa primeira hipótese para explicar essa dissociação se relaciona com a forma como os governos brasileiros e a mídia têm usado os eventos da Copa do Mundo para construir uma unidade que apaga as diferenças profundas existentes na sociedade do país. Considerando que as tiras brasileiras que analisamos estão publicadas em um jornal diário, a Folha de S. Paulo, cujo projeto editorial tem a crítica como um dos princípios de seu projeto editorial ${ }^{122}$, as produções poderiam refletir esse alinhamento.

A outra hipótese diz respeito também à desigualdade histórica que marca a realidade brasileira. Pensando nos autores das tiras, no público leitor e na população em geral, entendemos que a diferença social entre esses três segmentos no que se refere à Argentina e o ao Clarín não era tão grande nos momentos estudados. Ao passo que se pensarmos no Brasil, a diferença entre esses três segmentos é muito maior. O público leitor da Folha de S. Paulo não representa socialmente de forma alguma a maioria da população brasileira. Talvez não possamos falar que representa uma elite econômica, mas com certeza uma elite escolarizada, sim. Elite essa que possivelmente vê o futebol como

\footnotetext{
${ }^{122}$ Texto disponível em http://temas.folha.uol.com.br/projeto-editorial-da-folha/projeto-editorial-folha-de-s-
} paulo/principios-editoriais.shtml. Acesso em 11/12/2017. 
algo menor. Como última hipótese, lembremos que local em que as tiras são publicadas em ambos os jornais tem um papel importante. A Ilustrada é um caderno dedicado à cultura e entretenimento e isso também pode atuar como uma variável a ser considerada pelos quadrinistas.

\subsubsection{Sobre as vitórias}

Para concluir, abordaremos um último aspecto que nos chamou a atenção na comparação entre os conjuntos de tiras com os quais trabalhamos. Trata-se da diferença verificada nas produções que analisamos quanto aos sentidos construídos, ou silenciados, a respeito dos bons resultados nos dois países.

Comecemos com a Copa de 1994, ganha pelo Brasil. A conquista se deu após 24 anos do tricampeonato no México e nossa hipótese era que encontraríamos tiras em que isso seria abordado, mesmo que de forma crítica. Porém, diferentemente de nossa expectativa, verificamos um silenciamento a respeito da conquista. Não encontramos tiras sobre o acontecimento. Por outro lado, foram publicadas produções ao longo do campeonato em que o futebol foi tematizado em uma perspectiva de esvaziamento de seus potenciais sentidos simbólicos para o país. Esse mesmo posicionamento, em referência específica à Copa, não ao futebol em geral, identificamos em uma charge de autoria de Laerte publicada no mesmo caderno em que coletamos as tiras e que foi incorporada à nossa narrativa. Nela, a conquista da taça foi igualada a mais uma oportunidade de roubo para os ladrões que já haviam levado a taça Jules Rimet.

Situação muito diferente encontramos no espaço discursivo da imprensa escrita argentina a respeito do vice-campeonato na Copa de 2014. Nas manchetes dos jornais argentinos, a interpretação quase unânime foi positiva, com enunciados em que se reiterava a ideia de orgulho pelo brio do time durante o jogo. Dessa forma a construção discursiva sobre o resultado da participação da seleção da Argentina na Copa foi na direção de ser assimilado como a conquista de um vice-campeonato e não como a perda de um primeiro lugar, contribuindo para a construção de uma auto-imagem positiva para o construto da nação Argentina. Já nas tiras publicadas no Clarín, embora não tenhamos encontrado a unanimidade das manchetes quanto à interpretação, tampouco encontramos procedimentos humorísticos com possíveis efeitos agressivos ou destrutivos, como o sarcasmo, por exemplo. 
No capítulo correspondente, elencamos nossas hipóteses para o que chamamos de silenciamento a respeito do tetracampeonato no conjunto das tiras brasileiras de 1994. Em primeiro lugar, estaria o descrédito que acompanhou a campanha da seleção de 1994 desde o início. Nesse sentido, trazemos uma reflexão de Damo (2006) a respeito do processo de identificação da população de um país com a seleção que a representa. Diz o autor (grifo nosso):

O processo de investimento da nação no time de futebol possui dupla face e pressupõe, entre outras coisas, um trabalho de mediação entre os brasileiros e os jogadores, comissão técnica, dirigentes, enfim, ao conjunto dos que integram 'a seleção'. É preciso fazer crer à comunidade de sentimento que aquele time representa-a, bem ou mal, e isso implica um jogo de sedução.

De nossa parte, apontamos que a disjuntiva colocada pelo autor, e que destacamos, talvez não se aplique no caso do Brasil. No campo discursivo do futebol brasileiro, a seleção de 1982 que perdeu a Copa na Espanha é referida com muito mais respeito e admiração que a vencedora de 1994. A razão está na forma como cada equipe jogava, os torcedores identificam o "estilo nacional" brasileiro na seleção de 1982, mas não no time de Parreira e em seu esquema tático defensivo. Para uma seleção merecer a admiração do torcedor brasileiro precisa corresponder ao imaginário criado ao redor dela.

Havendo contemplado todos os itens anunciados na introdução, finalizamos assim nossa exposição comparativa. No próximo capítulo apresentaremos as conclusões a respeito de nosso trabalho de pesquisa. 


\section{CAPÍTULO 6 - Conclusões}

Para encerrar esta tese, dirigiremos nosso olhar para cada um dos capítulos anteriores para retomar sinteticamente nossas conclusões e, quando pertinente, acrescentar reflexões sobre as possíveis contribuições e os limites de nossa pesquisa.

Dedicamos os três capítulos que formam a primeira parte desta tese à apresentação do arcabouço teórico e conceitual que fundamentou nossa investigação.

No capítulo 1, primeiramente discorremos sobre o conceito de gênero discursivo, como foi entendido neste trabalho e com que linhas teóricas nos alinhamos ao elegê-lo como objeto de estudo. Partimos de sua origem e de seu vínculo aos estudos literários, passamos por sua reconceituação nos estudos desenvolvidos no Círculo de Bakhtin e chegamos às diferentes abordagens que tem recebido no âmbito dos estudos linguísticos. Apoiando-nos em Beacco (2004), Maingueneau (2010) e em Fanjul (2015), circunscrevemos que em nosso trabalho entendemos que os gêneros discursivos são dispositivos de comunicação cujas características respondem às dimensões sóciohistóricas de sua produção e recepção. Desta sorte, o estudo de um gênero em uma dada sociedade, explorando a relação entre suas características discursivo-enunciativas, a espacialidade social e as circunstâncias históricas, pode nos proporcionar diferentes dados sobre essa sociedade. A partir do conceito de campo social de Bourdieu ([1976] 2002; [1970] 2007), efetuamos um recorte teórico-metodológico para delimitar a inserção do gênero tira cômica na espacialidade social na qual o enfocamos. Assim, em nossa proposta vemos as tiras cômicas inseridas no campo do humor gráfico e quadrinhos, que por sua vez está inserido no grande campo cultural. Nosso objetivo naquele momento foi embasar a perspectiva com que analisamos a cena englobante e a cena genérica das tiras cômicas, temas do quarto capítulo de nosso trabalho. Em que pese haver sido uma necessidade criada pelas particularidades de nossa pesquisa, acreditamos que uma primeira contribuição de nossa investigação foi o diálogo que estabelecemos entre os três primeiros autores citados neste parágrafo, para problematizar o uso do conceito de comunidades discursivas em trabalhos com gêneros do espaço midiático. Partimos do posicionamento defendido por Fanjul (2015) em um diálogo estabelecido com Beacco (2004), alinhando-nos com o primeiro, e ampliamos a justificativa baseando-nos em Maingueneau (2010) e no próprio Beacco (2004).

Para operacionalizar a análise das tiras enquanto um gênero discursivo, mobilizamos reflexões conceituais desenvolvidas por Maingueneau $(2001,2010)$ e outros 
especialistas da Análise do Discurso. Assim, num segundo momento do capítulo 1 apresentamos o conceito de cena da enunciação de Maingueneau e as quatro outras dimensões em que ele o divide: cena englobante, cena genérica, cenografia e cena validada. Estabelecemos uma relação entre cena validada, estereótipo, memória e ethos, vínculo também estabelecido por Gatti (2013) em pesquisa igualmente desenvolvida sobre tiras cômicas.

Finalizamos o primeiro capítulo apresentando os conceitos de particitação e hiperenunciador, que também foram mobilizados no trabalho de análise. Esses conceitos revelaram-se especialmente produtivos na interpretação de enunciados presentes nas tiras, que correspondiam a citações provenientes de diferentes agrupamentos sociais representando enunciadores coletivos.

O capítulo 2 foi dedicado ao humor. Primeiramente, introduzimos as reflexões de Lipovetsky ([1983] 2005) a respeito do humor na contemporaneidade e as relacionamos a outras conclusões de estudos a propósito do mesmo assunto. Nosso objetivo foi mostrar que o humor também sofre coerções sócio-históricas e que igualmente pode ter um papel social. Num segundo momento, resenhamos os principais estudos sobre seu funcionamento e constatamos que a incongruência está de alguma forma presente em todas as concepções. Nessa parte mencionamos também propostas desenvolvidas no âmbito dos estudos linguísticos e pesquisas sobre o humor que estão sendo levadas a cabo nas diferentes disciplinas nele abrigadas, tais como a Linguística Cognitiva e a Pragmática. $\mathrm{Na}$ atualidade, os estudos têm procurado avançar na direção de investigar outros textos que não as piadas, consideradas como gênero prototípico quando se fala de humor. Após essa visão panorâmica, introduzimos a proposta de Charaudeau (2006) para o estudo do humor, cujas categorias foram usadas para abordar a dimensão humorística das tiras cômicas, nas análises que são tema do capítulo 5.

O capítulo 3 foi dedicado a resenhar as leituras que efetuamos a respeito do papel do futebol na construção identitária do Brasil e da Argentina, e a explicitar o recorte que fazemos do tema em nosso estudo. Primeiramente, efetuamos uma primeira aproximação ao conceito de identidade mediante contribuições da Psicologia Social (CIAMPA, [1984] 2001) e dos Estudos Culturais (WOODWARD, [1997], 2014; SILVA, [2000] 2014). Vimos que a noção de identidade atualmente tem uma abordagem não essencialista, que se trata de uma construção em que a linguagem tem um papel fundamental. A identidade, tanto em sua dimensão individual como coletiva, não é algo fixo e imutável. Trata-se de um construto submetido a forças de fixação e desestabilização. Num segundo momento 
do capítulo, passamos a resenhar os estudos sobre o futebol e as identidades nacionais. Para fazê-lo, a partir de contribuições de brasileiros (FRANCO JÚNIOR, 2007; WISNIK, 2008) e argentinos (FRYDENBERG, 2011) retomamos sua historicidade como esporte, sua chegada ao Brasil e à Argentina e como se deu sua popularização nos dois países. Igualmente sinalizamos as semelhanças e diferenças nesse processo e sua repercussão para as representações simbólicas construídas em torno do esporte nos dois países. Para essas reflexões, nos apoiamos em estudos da área da sociologia e da antropologia (ARCHETTI, 1995; ALABARCES, 2006; GUEDES, 2006). Finalizamos o capítulo focalizando as Copas do Mundo de Futebol. Como vimos, nesses eventos os países participantes são reificados em suas seleções e entram em cena diferentes representações simbólicas a respeito das identidades nacionais. Por conseguinte, os discursos produzidos em torno desses acontecimentos são especialmente significativos para pesquisas envolvendo a construção de sentidos em torno de valores identitários, daí resultando sua relevância para nosso estudo.

Os dois capítulos que formam a segunda parte de nossa tese trazem a dimensão mais propriamente analítica do trabalho.

No primeiro deles, o capítulo 4, abordamos o quadro cênico das tiras cômicas, a saber, a cena englobante e a cena genérica, segundo Maingueneau (2001, 2010). Nesse capítulo retomamos o percurso histórico do gênero tira cômica e sua relação com os jornais diários. Localizamos suas origens e contrastamos sua estabilização no campo que denominamos do humor gráfico e quadrinhos, tanto na Argentina como no Brasil, interpretando as consequências das diferentes condições sócio-históricas em que esse processo se deu nos dois países. Com relação especificamente à Folha de S. Paulo e ao Clarín, apontamos que as peculiaridades de cada um dos veículos, na historicidade de sua relação com as tiras cômicas, repercutem não só nas produções, como também na forma como os autores são percebidos no campo dos quadrinhos e do humor gráfico. Como especialmente no lado brasileiro ainda há muito que explorar na historicidade do gênero tira cômica no país, acreditamos que o caminho que traçamos nessa parte de nosso estudo possa contribuir para as futuras pesquisas que abordem a história do gênero no Brasil, somando-se a iniciativas já existentes nessa direção, como Ramos (2015a).

O capítulo 5 traz a análise, em forma de estudo de caso, de tiras publicadas no Clarín e na Folha de S. Paulo por ocasião do período de realização das Copas de 1994 e 2014. Embora já tenhamos apresentado conclusões parciais e comparativas, parece-nos oportuno destacar aqui alguns aspectos. 
Nosso propósito ao escolher essas duas edições da Copa era investigar como as tiras cômicas publicadas nas ocasiões dialogavam com os acontecimentos que envolviam ambas seleções. Assinalamos que tínhamos resultados semelhantes mas espelhados: vitória do Brasil e eliminação traumática da Argentina em 1994, e em 2014, eliminação traumática do Brasil e em certa medida uma vitória da Argentina. Pareceu-nos que o recorte atendia aos nossos propósitos investigativos, uma vez que nossos objetivos de pesquisa eram examinar a relação entre as tiras cômicas publicadas em jornais diários, enquanto gêneros discursivos, os acontecimentos do contexto sócio-histórico, os discursos sobre o futebol e os sentidos em torno da identidade nacional nos dois países.

Para apresentar a análise, trouxemos dados sobre cada uma das edições do campeonato e sobre os sentidos construídos na imprensa a respeito dos resultados de cada uma das seleções. Tivemos que lidar com o fato de não termos encontrado na Folha de $S$. Paulo tiras que abordassem a conquista brasileira em 1994. Não obstante, construímos uma interpretação a respeito desse dado. Com relação à Copa de 2014, por ter se realizado no Brasil e em um momento especialmente complexo em termos políticos e sociais, trouxemos contribuições de estudiosos do futebol como objeto do conhecimento para enriquecer o recorte que fizemos para descrever aquele contexto.

A respeito da eliminação da seleção argentina da Copa de 1994, vimos que nas tiras a repercussão do acontecimento foi tematizada mostrando envolvimento emocional entre os locutores-personagens e os torcedores, lamentando o ocorrido de forma não crítica. Já sobre a derrota do Brasil em 2014, os discursos que encontramos nas tiras que analisamos abordavam a dimensão do inesperado "tamanho" da derrota, bem como mostravam posicionamentos críticos a respeito de seu impacto para a sociedade. Constatamos posicionamentos sobre a derrota que envolviam uma relação polêmica entre dados da realidade nacional e o impacto emocional, social e simbólico que os 7 a 1 representaram.

Sobre as vitórias, por outro lado, como já mencionamos, no espaço discursivo que delimitamos para a análise verificamos com relação à conquista do Brasil em 1994: (i) tiras sobre o futebol em que valores associados ao esporte eram colocados em causa, tornando-se o esporte objeto do humor; (ii) nenhuma tira sobre o tetracampeonato da seleção brasileira e (iii) uma charge esvaziando completamente o sentido simbólico da conquista. Já quanto ao desempenho final da seleção argentina em 2014, verificamos que no discurso da imprensa em geral os enunciados construíam uma interpretação positiva do acontecimento: como a conquista de um vice-campeonato e não como a perda de um 
primeiro lugar. Especificamente no espaço discursivo que enfocamos, encontramos tanto tiras em que o acontecimento era tematizado na mesma direção que acabamos de apontar, como também de forma mais crítica, relativizando a importância da conquista. De qualquer forma, é oportuno sinalizar que, em nosso ponto de vista, o tom das críticas era menos contundente e agressivo que nas produções brasileiras. Parece que somos um povo que tende a hiperbolizar os fracassos. Ademais, ao menos no que se refere aos espaços de identificação e reconhecimento representados pelo futebol na Copa do Mundo, tendo em vista o que observamos em nossa análise a respeito do tetracampeonato de 1994, só reconhecemos conquistas que em sua consecução atendem a parâmetros presentes na memória discursiva, que respondem principalmente à dimensão estética da forma de jogar.

Não obstante os limites de nossa pesquisa quanto a generalizar conclusões, que reconhecemos e em vários momentos destacamos, essa diferença na interpretação das conquistas e das derrotas que identificamos nas produções ensejam alguns comentários.

Em uma pesquisa efetuada no âmbito teórico-metodológico dos estudos a respeito da cortesia linguística em enfoque sócio-cultural, Boretti (2000), fazendo as devidas advertências e ressalvas a respeito de generalizações, aponta algumas ideias relacionadas à identidade argentina que dialogam com o que observamos nos dados argentinos com relação à interpretação do vice-campeonato em 2014.

A autora afirma que, tal como ocorre com outras nacionalidades, a herança cultural que opera sobre a construção da identidade argentina tem suas raízes na história da conquista e da colonização. Segundo ela, vários autores indicam que o autoritarismo e o descumprimento da lei que podem ser identificados na sociedade argentina teriam como uma de suas causas os sistemas de estruturas rígidas e hierárquicas presentes nesses primórdios de leis minuciosas, mas distantes e, por conseguinte, proclives a serem desconhecidas. A autora afirma que:

Si nos remitimos a estos datos históricos, es posible identificar, ya en los orígenes, uno de los contenidos representativos que con distintos matices y en distintos niveles, a través del tiempo, ha constituido un aspecto de la imagen básica ideal argentina, heredado tal vez de España: el deseo de autoafirmación de los derechos propios y de las aspiraciones legítimas. (BORETTI, op. cit., p. 85); 
Em outro momento, já se referindo ao detalhamento das premisssa de autonomia e afiliação propostas por Bravo (1998), Boretti (2000) afirma que em certos grupos sociais argentinos observa-se que

la autoestima forma parte del ser social y está ligada al sentimiento de orgullo, que puede ser expresiva y claramente manifestado; es fuente de modos de acción directos y frontales que permiten que el individuo se confirme socialmente. La autoestima es merecedora del interés, admiración y aprecio, dentro del grupo (idem, p. 90).

Verificamos que alguns dos enunciados dos locutores-personagens das tiras de nosso corpus polemizam ou se alinham com o afirmado pela autora com relação à autoafirmação. Assim, uma possibilidade de pesquisas futuras em outros linhas teóricas, por exemplo, é debruçar-se sobre o corpus que construímos para investigar a gestão da imagem (cf. GOFFMAN, 1970) de argentinos e brasileiros nas tiras publicadas por ocasião de acontecimentos envolvendo as seleções nas Copas. Uma tendência que percebemos em tiras argentinas é a da construção de autoimagem positiva para o país, que ao fim e ao cabo reverteria em benefício próprio para sua população. Em tiras brasileiras, por outro lado, percebemos o movimento contrário.

Já os posicionamentos que observamos nos dados brasileiros, por sua vez, dialogam também com reflexões sobre o construto Brasil enquanto Estado-nação e sobre “os brasileiros". Trazemos a esse respeito alguns fragmentos da obra em que José Miguel Wisnik (2008) alia uma interpretação do Brasil a reflexões sobre o futebol. Vamos a elas:

Volta e meia fala-se da ideia do "país do futuro", com a obrigatória alusão depreciativa ao livro de Stefan Zweig, como uma ilusão compensatória do atraso. Mas a ideia fixa do país do fracasso, que vem associada automaticamente a essa crítica é um efeito mais enviesado e mais capcioso da mesma síndrome. (op. cit. p.408)

Uma revisitação aos intérpretes do Brasil da década de 30 nos faz lembrar de quanto está contida e rebatida, neles, a concentração de visadas positivas e negativas que se manifestam cruzadas nos fenômenos do grande escritor e do grande jogador. Pode-se dizer que as características da "formação do Brasil contemporâneo" em Caio Prado Júnior aparecem ao maior analista do nosso atraso como um veneno contaminante; que o mesmo processo, visto por Gilberto Freyre em Casa grande \& senzala, ganha as propriedades de um remédio - a ideia da civilização mestiça e original nos trópicos; e que em Raízes do Brasil de Sérgio Buarque de Holanda, essa formação destila um implícito e ambivalente veneno remédio - o "homem cordial" afetivo e arbitrário, afável e truculento, personalista e inconsequente. Essas diferenças como modulações de um mesmo campo problemático em que a droga-Brasil, aparecendo ora num pólo, ora noutro resiste como um fármacon rebelde à neutralização. (idem, p. 409) 
No segundo fragmento citado, o "grande escritor" se refere a Machado de Assis, e o "grande jogador" a Pelé. No capítulo do qual extraímos as citações, Wisnik (2008) desenvolve suas reflexões trazendo ambos à cena para discorrer sobre o que ele chama de "xis do problema". Conforme o autor, ambos os personagens

são necessários para que se formule a trama de um país mal letrado e exorbitante, cuja destinação passa pelas reversões entre a "alta" e a "baixa" cultura, pelo confronto e pelo contraponto das raças, pela palavra e pelo corpo, e cuja "formação" não poderia se dar apenas na literatura: o ser brasileiro pede minimamente - para se expor em sua extensão e intensidade - a literatura, o futebol e a música popular.

Como vimos, algumas das conclusões a que chegamos na análise de nossas produções dialogam com o apontado por Wisnik (2008). No que diz respeito ao futebol, mostramos que no lado brasileiro das produções por nós enfocadas encontramos com mais frequência vozes que indicavam posicionamentos que pareciam mostrar uma dificuldade de assumir-se torcedor brasileiro, e ao mesmo tempo vozes que silenciaram e não vibraram pelo que poderia ser uma valorização da autoimagem do país. Não podemos esquecer que trabalhamos com um gênero produzido e consumido por representantes da classe média brasileira, escolarizada e de condição sócio-econômica satisfatória para suas necessidades básicas. Seria a origem popular do futebol uma das causas dos posicionamentos que apontamos? Ou o fato de o esporte ter sido usado exaustivamente pelos governantes para capitalizarem sua imagem? Igualmente são perguntas que podem nortear futuras pesquisas.

Outro dado que gostaríamos de destacar refere-se às marcas de pertencimento e inclusão que encontramos em nosso corpus de trabalho. Retomando os resultados comparados, verificamos nos enunciados das tiras argentinas marcas de inclusão e pertencimento por parte dos locutores-personagens. Nas tiras brasileiras, por seu turno, nos enunciados dos locutores-personagens encontramos marcas de não inclusão e uma enunciação a partir de um ponto de vista externo ao abordar os eventos envolvendo seleção do país. Além de dialogar com os resultados da pesquisa de Russo (2013) que mencionamos anteriormente, encontramos em Fanjul (2015) e Celada (2005) algumas pistas que podem ser seguidas em novas pesquisas que compreendam um número maior de tiras na análise. Celada (2005) reflete sobre uma forma de enunciar de maneira generalizante em português brasileiro caracterizada por um substantivo singular (sem determinante) + verbo ser em terceira pessoa do singular, como em "brasileiro é assim 
mesmo". Um argentino expressaria a mesma ideia usando a primeira pessoa do plural: los argentinos somos así. Em seu estudo, Celada (2005) associa essas formas a uma enunciação proverbial e levanta como hipótese a relação que nós brasileiros mantemos com nossa própria língua, como uma herança colonial. Nas palavras da autora:

La propia forma lingüística que analizamos, que abusa del goce de una prosodia, podría ser vista como una forma de decirse brasileño y, en este sentido, tal estructura es síntoma de un sujeto afectado por una lengua de colonización - con todo lo que esto implica si pensamos en una escuela pública que, de forma general, forja una serie de relaciones específicas: entre sujeto y oralidad/escritura, entre sujeto y simbólico, entre el primero y el discurso gramatical, todas ellas permeadas inclusive por las exigencias de autoría que esa institución impone.

Em Fanjul (2015), o autor realiza uma reflexão bastante amadurecida a respeito da expressão da instância de pessoa, um de seus objeto de estudo como pesquisador. Na obra, revisita pesquisas anteriores suas e de outros especialistas que se dedicaram a comparar as discursividades argentina e brasileira. $\mathrm{O}$ autor lança novos olhares interpretativos para os resultados dessas pesquisas. Esses olhares fundamentam-se nas diferenças com relação à desigualdade social e à percepção da hierarquia e das assimetrias de poder nos dois países.

Retomando dados de nosso trabalho a respeito da referência à pessoa, tanto em Fanjul (2015) como em Celada (2005) encontramos possíveis trilhas a serem também seguidas em pesquisas futuras com um corpus mais amplo do que aquele com que trabalhamos em nosso recorte.

Passando a aspectos mais gerais para concluir esse processo e começando pelas limitações, reportamos importante mencionar o fato de sermos brasileira, morarmos no Brasil e de que nosso contato com o espanhol e com a Argentina se dá como estrangeira. Assim, nossas conclusões estão sempre mediadas por essa subjetividade. Outra limitação a citar é que o instrumental analítico que decidimos usar e o recorte que fizemos nos impôs limites quanto ao número de tiras abordadas e apresentadas. Tratamos de efetuar uma análise detalhada de cada produção e temos consciência de que deixamos de enfocar algumas informações. Como consequência, nosso estudo tem restrições quando a possíveis generalizações.

Enfocando nossa abordagem do discurso humorístico, a proposta de Charaudeau (2006), em nosso ponto de vista, por um lado revelou-se produtiva, especialmente no que se refere a sua reflexão sobre os possíveis efeitos de um ato de humor sobre o destinatário. Por outro lado, o englobar diferentes fenômenos sob uma mesma categoria, 
em alguns momentos dificultou a análise e nos pareceu apagar certas nuances. Um dos pontos mais problemáticos se refere à categoria descrita pelo autor como jogo irônico. Tivemos de buscar subsídios em outros olhares sobre o tema para dar conta de descrevêlo. Por outro lado, é preciso ponderar que a ironia é um dos temas que mais recebeu atenção tanto nos estudos sobre o humor como sobre a enunciação, trata-se portanto de um fenômeno complexo que possivelmente não possa ser abarcado em uma só visão.

No que se refere às possíveis contribuições de nosso estudo em seu âmbito geral, parece-nos que podemos ter corroborado que as tiras cômicas são um gênero discursivo que merece ser considerado em sua individualidade e complexidade de funcionamento, como já apontado por outros pesquisadores que se dedicaram ao gênero como Nepomuceno (2005) e Ramos (2011). As produções locais de ambos os países se revelaram fontes especialmente ricas para investigar, entre outros temas, a relação entre o contexto sócio-histórico e sua discursivização, estereótipos relacionados aos mais diferentes temas e o funcionamento do discurso humorístico. Igualmente acreditamos que nossas análises demonstraram que o futebol, em seus mais diferentes aspectos, constitui uma rica fonte para pesquisas no âmbito dos estudos discursivos.

Outro ponto a destacar é que o projeto do qual esta tese é o resultado começou ambiciosamente como um estudo diacrônico que abarcaria vinte anos, e finalizou como uma tese em que apresentamos dois estudos de caso, um do início e outro do final do período inicialmente considerado. Como legado desse processo, além do aprendizado, esse intangível, de equacionar as variáveis envolvidas na realização de um trabalho de pesquisa, temos também um corpus considerável - esse tangível - que possibilitará certamente muitas outras pesquisas futuras.

Finalizaremos com uma breve reflexão sobre um último legado, esse no âmbito pessoal e igualmente da ordem do intangível e subjetivo. Os cineastas Ana Luiza Azevedo e Jorge Furtado, com base na obra Anatomia de uma derrota, que o jornalista Paulo Perdigão escreveu sobre o Maracanazo, dirigiram o filme Barbosa, um curtametragem. No filme, o personagem interpretado por Antonio Fagundes, por obra e graça de uma máquina que inventara, volta à partida contra o Uruguai em 1950 na tentativa de reverter a derrota do Brasil e assim, redimir o goleiro Barbosa, injustamente acusado de ter sido o responsável pela derrota. Ali, no Maracanã recém-inaugurado, vê a si mesmo com onze anos vibrando de alegria ao lado do pai após o primeiro gol do Brasil, no único abraço que dele receberia ao longo de toda sua vida. Ao término do jogo, no silêncio ensurdecedor em que se converteu o estádio após a derrota brasileira, sua voz como 
narrador em off nos conta que a experiência lhe fizera reviver seu primeiro contato com o que era "contingente e absurdo", e que a derrota era um sinal de que neste país "nada nunca vai dar certo".

A cena do filme instalou-se em nossa memória desde a primeira vez que a vimos e visitou-nos durante boa parte da realização deste trabalho. Como brasileira, talvez nunca nos tenhamos defrontado com tantas contingências e absurdos como nos últimos anos. As leituras e reflexões durante a pesquisa, bem como a escrita desta tese, nos possibilitaram voltar a esses momentos com distanciamento e, consequentemente, construir uma compreensão mais aprofundada sobre o país e sobre quem somos, não obstante o "contingente e absurdo" que parece nos constituir. 


\section{Referências bibliográficas}

ACADEMIA ARGENTINA DE LETRAS. Diccionario del habla de los argentinos. Buenos Aires: Espasa, 2003.

ACAMPORA, Ricardo. Brasil é tetracampeão. 1994. Disponível em: <http://www.bbc.com/portuguese/noticias/2002/020326 copa94.shtml >. Acesso em: 20 mai. 2017.

ALABARCES, Pablo. Fútbol y patria: el fútbol y las narrativas de la nación en la Argentina. Buenos Aires: Prometeo, 2002.

ALABARCES, Pablo. Entre el infierno y la gloria: crisis, política y mundiales: Argentina y Copa del Mundo de 2002. In: GASTALDO, Édison e GUEDES, Simoni Lahud (Org.). Nações em campo: Copa do Mundo e identidade nacional. Niterói: Intertexto, 2006, p. 197-221.

ALABARCES, Pablo. Fútbol, música, narcisismo y estado en "Brasil, decime qué se siente". In: MARQUES, José Carlos (Org.). A Copa das Copas? Reflexões sobre o Mundial de Futebol de 2014 no Brasil. São Paulo: Edições Ludens, 2015. p. 95-120.

ALABARCES, Pablo. Maradona, el fútbol, la patria, el peronismo y otros gremios paralelos: Un héroe en disponibilidad. Encrucijadas, Universidad de Buenos Aires. n. 33, julho 2005. Disponível em: <http://repositoriouba.sisbi.uba.ar/gsdl/collect/encruci/index/assoc/HWA 529.dir/529.PD F>. Acesso em: 10 mai. 2016.

AMOSSY, Ruth e PIERROT, Anne Herschberg. Estereotipos y clichés. Tradução ao espanhol: Lelia Gándara. Buenos Aires: Eudeba, 2001.

AMOSSY, Ruth. Da noção retórica de ethos à análise do discurso. In: AMOSSY, R. (Org.). Imagens de si no discurso: a construção do ethos. São Paulo: Contexto, 2005, p. 9-28.

ARCHETTI, Eduardo P.. Estilo y virtudes masculinas en El Gráfico: la creación del imaginario del fútbol argentino. Desarrollo Económico - Revista de Ciencias Sociales, Buenos Aires, v. 35, n. 139, p. 419-442, out./dez. 1995. Disponível em: <http://www.efdeportes.com/efd16/elgraf.htm>. Acesso em: 28 mar. 2016.

ATTARDO, Salvatore. Linguistic Theories of Humor. Berlim, Nova Iorque: Mouton de Gruyter, 1994.

BAKHTIN, Mikhail/ Volochínov, V.N. Marxismo e filosofia da linguagem. São Paulo: Hucitec, 1986.

BAKHTIN, Mikhail. Os gêneros do discurso. In: Estética da criação verbal. São Paulo: Martins Fontes, 1992 (1979) [1952-1953], p. 277-326.

BAKHTIN, Mikhail. El problema de los géneros discursivos. In: Estética de la creación verbal. Trad. Tatiana Bubnova. Buenos Aires: Siglo XXI, 2008 . p. 247-290. 
BARBOSA. Direção: Ana Luiza Azevedo e Jorge Furtado. Roteiro: Ana Luiza Azevedo, Giba Assis Brasil e Jorge Furtado. Porto Alegre: NGM Produções e Promoções/Luz Produções, 1988.12 minutos. 12 Disponível em: <https://www.youtube.com/watch?v=NAApOKrH318>. Acesso em: 01 jul. 2017.

BEACCO, Jean-Claude. L'astronomie dans les médias. Analyses linguistiques de discours de vulgarisation. Paris: Presses de la Sorbonne nouvelle, 1999.

BEACCO, Jean-Claude. Trois perspectives linguistiques sur la notion de genre discursif. Langage, v. 38 , n. 153, p. 109-119, 2004. Disponível em: <http://www.persee.fr/doc/lgge 0458-726x 2004 num 38153 939>. Acesso em: 10 dez. 2015.

BEACCO, M. Jean-Claude. Três perspectivas linguísticas sobre a noção de gêneros discursivos. Tradução Ana Gleysce Moura de Brito. [Original em francês: Trois perspectives linguistiques sur la notion de genre discursif]. Miguilim - Revista Eletrônica do Netlli, Crato, v. 2, n.1 p.187-204, abr. 2013. Disponível em: <http://periodicos.urca.br/ojs/index.php/MigREN/article/viewFile/441/389>. Acesso em: 12 dez. 2015.

BERGSON, Henri. La risa: ensayo sobre el significado de lo cómico. Tradução Amalia Haydée Raggio. Buenos Aires: Losada, 2009.

BERRENDONNER, Alain. Elementos de Pragmática Lingüística. Tradução Margarita Mizraji. Buenos Aires: Gedisa, 1987.

BIBE-LUYTEN, Sônia M. O que é história em quadrinhos. São Paulo: Brasiliense, 1985.

BITENCOURT, Fernando Gonçalves. Esboço sobre algumas implicações do futebol e da Copa do Mundo para o Brasil: identidade e ritos de autoridade. Revista Brasileira de Ciências do Esporte. Campinas, v.30, n.3, p.173-189, 2009.

BORETTI, Susana H. Cortesía lingüística e imagen en el español coloquial de la Argentina. Revista Argentina de Lingüística, n. 16, p. 77-107, 2000. Disponível em: <http://www3.cricyt.edu.ar/ral/vols/v16/boretti.pdf >. Acesso em: 03 fev. 2013.

BOURDIEU, Pierre. Campo de poder, campo intelectual: itinerario de un concepto. Tucumán: Editorial Montressor: 2002.

BOURDIEU, Pierre. O mercado de bens simbólicos. Tradução Sergio Miceli. In: A Economia das trocas simbólicas. São Paulo: Perspectiva, 2007, p. 99.

BOURDIEU, Pierre. El sentido social del gusto. Elementos para una sociología de la cultura. Tradução e apresentação de Alicia Gutiérrez. Buenos Aires, Siglo XXI, 2010.

BRAIT, Beth. Ironia em perspectiva polifônica. Campinas: Editora da Unicamp, 1996.

BRAIT, Beth e PISTORI, Maria Helena. A produtividade do conceito de gênero em Bakhtin e o Círculo. Alfa Revista de Linguística, v. 56, $\mathrm{n}^{\circ}$ 2, 2012. Disponível em: <http://www.scielo.br/pdf/alfa/v56n2/02.pdf >. Acesso em: 23 fev. 2016. 
BRAVO, Diana. ¿Reirse juntos? Un estudio de las imágenes sociales de hablantes españoles, mexicanos y suecos. Haverkate, Henk et alii (eds.) La pragmática linguística del español. Recientes desarrollos. Diálogos Hispánicos, n. 22, Amsterdam: Rodopi, 1998.

CALOI. Clemente es mundial. Buenos Aires: Planeta, 2014.

CAMPOS, Flavio e ALFONSI, Daniela (Org.). Futebol - Objeto das Ciências Humanas. São Paulo: Leya, 2014.

CAMPOS, Flavio de. A copa da política em um país do futebol. In: MARQUES, José Carlos (Org.). A Copa das Copas? Reflexões sobre o Mundial de Futebol de 2014 no Brasil. São Paulo: Edições Ludens, 2015, p. 31-38.

CARMELINO, Ana Cristina e RAMOS, Paulo. Uma trajetória das pesquisas linguísticas sobre humor no Brasil. In: CARMELINO, Ana Cristina (Org.). Humor: eis a questão. São Paulo: Cortez, 2015, p. 7-17.

CARRIBURO, Norma. Las fórmulas de tratamento en el español actual. Madri: Arco/Libros, 1997.

CARVALHO, Carlos e ZILBERMAN, Eduardo. Frustration and Voting Behavior: Evidence from Stock Market Data. Abril 2017. Disponível em: <https://ssrn.com/abstract=2930564>. Acesso em: 01 jun. 2017.

CLARÍN, Buenos Aires, Argentina. AGEA - Arte Gráfico Editorial Argentino S.A.. Edições diárias de maio/junho de 1994 e junho/ julho de 2014.

CELADA, María Teresa. Estructura y cristalización. Acerca de la productividad de ciertas formas linguísticas del portugués brasileño en los procesos de homogeneización ideológica. In : Actas del XIV Congreso de ALFAL. Monterrey, 2005. Sem numeração de páginas. Disponível em: 〈http://www.mundoalfal.org/cdcongreso/cd/pragmatica_analisis_discurso/celadam.html〉. Acesso em: 04 mai. 2017.

CHARAUDEAU, Patrick. De la competencia social de comunicación a las competencias discursivas. Revista latinoamericana de estudios del discurso, ed. Latina, Venezuela, v. 1, 2001. Disponível em: <http://www.patrick-charaudeau.com/De-la-competencia-socialde.html >. Acesso em: 17 jul. 2016.

CHARAUDEAU, Patrick. Des catégories pour l'humour ?. Revue Questions de communication n. 10, Presses Universitaires de Nancy, Nancy, 2006. Disponível em: $<$ http://www.patrick-charaudeau.com/Des-categories-pour-l-humour,93.html $>$. Acesso em: 19 jul. 2016.

CHARAUDEAU, Patrick. Discurso das mídias. Tradução Angela M.S. Corrêa. São Paulo: Contexto, 2015.

CHARAUDEAU, Patrick e MAINGUENEAU, Dominique. Dicionário de Análise do Discurso. Tradução coordenada por Fabiana Komesu. São Paulo: Contexto, 2004. 
CIAMPA, Antonio da Costa. Identidade. In: LANE, Silvia T.M.; CODO, Wanderley (Orgs.). Psicologia social: o homem em movimento. São Paulo: Brasiliense, p. 58-75, 2001.

COSTA, Leda. O vilão de sete vidas: da "tragédia de 1950" à "vergonha de 2014". Arquibancada, v. 62, ago. 2014. Disponível em: <http://www.ludopedio.com.br/arquibancada-volumes/volume-62/>. Acesso em: 02 jun. 2017.

COSTA, Paula Cesarino. Sobre o direito de sátira e de ousar. Folha de S. Paulo. Disponível em: <http://www1.folha.uol.com.br/colunas/paula-cesarino-costaombudsman/2016/07/1792380-sobre-o-direito-a-satira-e-limites.shtml>. Acesso em: 10 mai. 2017.

COUTO, José Geraldo. O eterno outro. Folha de S. Paulo. Disponível em: < http://feeds.folha.uol.com.br/fsp/esporte/fk2306200723.htm>. Acesso em: 16 out. 2016.

DAMATTA, Roberto. Antropologia do óbvio. Notas em torno do significado social do futebol brasileiro. Revista USP, São Paulo, v. 22, p. 10-17, 1994.

DAMO, Arlei Sander. O ethos capitalista e o espírito das copas. In: GASTALDO, Édison e GUEDES, Simoni Lahud (Org.). Nações em campo: Copa do Mundo e identidade nacional. Niterói: Intertexto, 2006.

DIJK, Teun A. van. Discurso e Contexto: Uma abordagem sociocognitiva. Tradução Rodolfo Ilari. São Paulo: Contexto, 2011.

DUCROT, Oswald. O dizer e o dito. Campinas: Pontes, 1987.

DUCROT, Oswald. La polifonía en lingüística. Polifonía y argumentación. Conferencias del Seminario Teoria de la Argumentación y análisis del discurso, Cali, Universidad del Valle, Cap.1: 15-23, 1988.

DUCROT, Oswald. El decir y lo dicho. Buenos Aires: Edicial, 2001.

E KORSTANJE, Maximiliano. Sacrificio y ejemplaridad. Comprendiendo los fenómenos de Leonel Messi y Diego A Maradona. Nómadas. Revista Crítica de Ciencias Sociales y Jurídicas, Universidade Complutense, Madri, v. 48, n. 2, ago. 2016. Disponível em: <http://revistas.ucm.es/index.php/NOMA/article/view/53300>. Acesso em: 06 jul. 2017.

EAGLETON, Terry. A ideia de cultura. Tradução Sandra Castello Branco. São Paulo: Editora da UNESP, 2000.

ECO, Umberto. A misteriosa chama da rainha Loana. Tradução Eliana Aguiar. Rio de Janeiro: Record, 2005.

FANJUL, Adrián. Prácticas comparativas sobre el español en Brasil: agentes y niveles. In: Carrielo, G; Ortiz, B; Miranda, F; Búsola, D. Tramos y tramas. Culturas, lenguas, literatura e interdisciplinar. Estudios comparativos. Rosario: Laborde Editor, 2011, pág. 39-56. 
FANJUL, Adrián Pablo. Unidades do discurso, indagação comparativa e proximidade linguística: perspectivas e limites da categoria de "gênero". Letras de Hoje, Porto Alegre, v. 50, n. 4, p. 508-517, out./dez. 2015. Disponível em: <http://revistaseletronicas.pucrs.br/ojs/index.php/fale/article/view/20235>. Acesso em: 26 ago. 2016.

FANJUL, Adrián Pablo. A pessoa no discurso: português e espanhol: novo olhar sobre a proximidade. São Paulo: Parábola. 2017.

FANJUL, Adrián e GONZÁLEZ, Neide (org.). Espanhol e português brasileiro: estudos comparados. São Paulo: Parábola, 2014.

FARACO, Carlos Alberto. Linguagem e Diálogo: as ideias Linguísticas do cÍrculo de Bakhtin. São Paulo: Parábola, 2009.

FARIAS, Airton de. Uma história das Copas do Mundo - futebol e sociedade. Fortaleza: Armazém da Cultura. 2014. Volume II.

FAUSTO, Boris e DEVOTO, Fernando. Brasil e Argentina. Um ensaio de história comparada (1850-2002). São Paulo: Editora 34, 2004.

FERNANDES, Geisa. Saberes Enquadrados: histórias em quadrinhos e (re)construções identitárias. 2010. 202 f. Tese (Doutorado em Ciências da Comunicação) - Universidade de São Paulo, São Paulo, 2010.

FOLHA DE S.PAULO, São Paulo, Brasil. Empresa Folha da Manhã S.A. Edições diárias de maio/junho de 1994 e junho/ julho de 2014.

FOLSTER, Letícia Beatriz. Textos culturais específicos: as traduções nas tiras de Mafalda para o português. 2013. 116 f. Dissertação (Mestrado em Estudos da Tradução) - Universidade Federal de Santa Catarina, Florianópolis, 2013.

FONSECA-SILVA, Conceição; MUSSALIM, Fernanda. Estereótipos de gênero e cenografias em anúncios publicitários. In: MOTTA, Ana Raquel; SALGADO, Luciana (Orgs.). Fórmulas Discursivas. São Paulo: Contexto, 2011, p. 139-150.

FORTES, Rafael. O Mundial de 2014 no imaginário popular brasileiro. In: MARQUES, José Carlos (Org.). A Copa das Copas? Reflexões sobre o Mundial de Futebol de 2014 no Brasil. São Paulo: Edições Ludens, 2015, p. 39-56.

FRANCO-JÚNIOR, Hilário. A dança dos deuses. Futebol, sociedade, cultura. São Paulo: Companhia das Letras, 2007.

FRYDENBERG, Julio. Historia social del fútbol: del amateurismo a la profesionalización. Buenos Aires: Siglo XXI, 2011.

FREUD, Sigmund. Os chistes e sua relação com o inconsciente. Rio de Janeiro: Imago, 1969. 
GANDARA, Lelia Mabel. Las voces del fútbol. Análisis del discurso y cantos de cancha. Literatura y lingüística, Santiago de Chile, n. 10, p. 43-66, 1997. Disponível em: <http://dx.doi.org/10.4067/S0716-58111997001000003>. Acesso em: 09 jun. 2017.

GARCÍA, Fernando. El hit de la selección. Informe Escaleno, 2014. Disponível em: 〈http://informeescaleno.com.ar/index.php?s=articulos\&id=184>. Acesso em: 20 jun. 2017.

GASTALDO, Édison. A Copa de 2014, entre o fascínio das ruas e o fascismo dos craques. In: Marques, J. C. (Org.). A Copa das Copas? Reflexões sobre o Mundial de Futebol de 2014 no Brasil. São Paulo: Edições Ludens, 2014.

GASTALDO, Édison e GUEDES, Simoni Lahud (Org.). Nações em campo: Copa do Mundo e identidade nacional. Niterói: Intertexto, 2006.

GIUNTA, Néstor Gustavo. La Historia del Cómic en la Argentina. Disponível em: <http://www.todohistorietas.com.ar/historia_argentina_1.htm>. Acesso em: 20 nov. 2013.

GATTI, Márcio Antônio. A Representação da Criança no Humor: um estudo sobre tiras cômicas e estereotipos. 2013. 264 f. Tese (Doutorado no Instituto de Estudos da Linguagem) - Universidade Estadual de Campinas, Campinas, 2013.

GOCIOL, Judith e ROSEMBERG, Diego. La historieta argentina: una história. Buenos Aires: Ediciones de la Flor, 2000.

GOCIOL, Judith e GUTIÉRREZ, José María. La historieta salvaje: Primeras series argentinas (1907-1929). Buenos Aires: Ediciones de la Flor, 2012.

GOFFMAN, Erving. Ritual de la interacción. Tradução direta do inglês de Floreal Mazia. Buenos Aires: Editorial Tiempo Contemporáneo. 1970.

GRÉSILlON, Almuth, MAINGUENEAU, Dominique. Polyphonie, proverbe et détournement, ou un proverbe peut en cacher un autre. Langages, v. 19, n.73, pp. 112125, 1984. Disponível em : <www.persee.fr/doc/lgge_0458726x 1984 num 1973 1168>. Acesso em: 30 mai. 2017.

GRIMSON, Alejandro (compilador). Pasiones Nacionales, política y cultura en Brasil y Argentina. Buenos Aires: Edhasa, 2007.

GUAZZELLI FILHO, Eloar. Canini e o anti-herói brasileiro: do Zé Candango ao Zé realmente - Carioca. 2009. 190 f. Dissertação (Mestrado em Ciências da Comunicação) Universidade de São Paulo, São Paulo, 2009.

GUEDES, Simoni Lahud. De criollos e capoeiras: notas sobre futebol e identidade nacional na Argentina e no Brasil. In: Associação Nacional de Pós-Graduação e Pesquisa em Ciências Sociais, XXVI, 2002, Caxambú. ANPOCS, Associação Nacional de Pós-Graduação e Pesquisa em Ciências Sociais. Congresso, Associação Nacional de Pós-Graduação e Pesquisa em Ciências Sociais, 2002. 
GUEDES, Simoni Lahud. O Brasil nas Copas do Mundo: tempo "suspenso" e história. In: Associação Brasileira de Antropologia, XXIII, 2002, Gramado. RBA - Reunião Brasileira de Antropologia, Associação Brasileira de Antropologia. Congresso, Associação Brasileira de Antropologia, 2002. Disponível em: $<$ http://www.ludopedio.com.br/biblioteca/o-brasil-nas-copas-do-mundo-tempo-suspensoe-historia/>. Acesso em: 01 jun. 2017.

GUEDES, Simoni Lahud. De criollos e capoeiras: notas sobre futebol e identidade nacional na Argentina e no Brasil. In: GASTALDO, Édison e GUEDES, Simoni Lahud (Org.). Nações em campo: Copa do Mundo e identidade nacional. Niterói: Intertexto, 2006.

GUEDES, Simoni Lahud. A dádiva e os diálogos identitários através das Copas do Mundo no Brasil. In: CAMPOS, Flavio e ALFONSI, Daniela (Org.). Futebol - Objeto das Ciências Humanas. São Paulo: Leya, 2014, pp. 57-69.

GUTERMAN, Marcos. O futebol explica o Brasil: Uma história da maior expressão popular do país. São Paulo: Contexto, 2014.

GUTIÉRREZ, J. M. La historieta argentina: de la caricatura política a las primeras series. Buenos Aires: Ediciones Biblioteca Nacional/Página 12, 1999.

HALL, Stuart. Quem precisa da identidade? In: SILVA, Tomaz Tadeu (Org.). Identidade e diferença: a perspectiva dos estudos culturais. Petrópolis: Vozes, 2009, p. 103-133.

HELAL, Ronaldo. "Jogo bonito" y fútbol criollo: la relación futbolística Brasil-Argentina en los medios de comunicación. In: GRIMSON, Alejandro (Org.). Pasiones Nacionales. Política y cultura entre Brasil y Argentina. Buenos Aires: Edhasa: 2007.

HELAL, Ronaldo. Fútbol, Comunicación y Nación: la trayectoria del campo académico en Brasil. Lúdicamente, ano 3, n. 6, out. 2014. Disponível em: <http://ppct.caicyt.gov.ar/index.php/ludicamente/issue/view/326/showToc>. Acesso em 04 set. 2015.

HELAL, Ronaldo. "Los Unos" e "Los Otros": a imprensa argentina narra o futebol brasileiro. In: XXIX Congresso Brasileiro de Ciências da Comunicação, Intercom Sociedade Brasileira de Estudos Interdisciplinares da Comunicação. Disponível em: <http://www.intercom.org.br/papers/nacionais/2006/resumos/R0357-1.pdf>. Acesso em: 28 out. 2015.

HUYSSEN, Andreas. Seduzidos pela memória: arquitetura, monumentos, mídia. Rio de Janeiro: Aeroplano, 2000.

IGLESIAS, Waldemar. Cuando a Diego le cortaron las piernas: ¿el complot que no fue? Jornal Clarín, 18 jun. 2014. Disponível em: <https://www.clarin.com/mb2014/Diegocortaron-piernas 0 Sy9cIS39PXl.amp.html>. Acesso em: 02 fev. de 2017.

KERBRAT-ORECCHIONI, Catherine. La Enunciación: de la subjetividad en el lenguaje. Tradução ao espanhol: Gladys Anfora e Emma Gregores. Buenos Aires: Edicial S.A., 1997. 
KLEIMAN, Angela. Texto e leitor: aspectos cognitivos da leitura. Campinas: Pontes, 1992.

KOCH, Ingedore Villaça. As tramas do texto. São Paulo: Contexto, 2014.

LEVÍN, Florencia Paula. Representaciones sobre la violencia a través del humor gráfico en la Argentina de la década de 1970: el caso del diario Clarín. In: BOHOSLAVSKY, Ernesto; FRANCO, Marina; IGLESIAS, Mariana; LVOVICH, Daniel. Problemas de historia reciente del Cono Sur: volumen 2. Buenos Aires: Prometeo, p. 201 a 222, 2010.

LEVÍN, Florencia Paula. El humor reprimido. Tiras y viñetas del diario Clarín durante los años de represión y censura (Argentina, 1974 - 1982). Confluenze - Rivista di Studi Iberoamericani, Bologna, v. 4, n. 2, p. 232-273, 2012. Disponível em: <https://confluenze.unibo.it/article/view/3441>. Acesso em: 7 jan. 2015.

LEECH, Geoffrey N. Principios de Pragmática. Tradução ao espanhol de Felipe Alcántara Iglesias. Logroño: Universidad de la Rioja, 1997.

LEFFA, Vilson. J. Fatores da compreensão na Leitura. Cadernos do IL. v.15, n. 15, 1996. p.143-159. Disponível em: 〈http://www.leffa.pro.br/textos/trabalhos/fatores.pdf $>$ Acesso em: 03 mai. 2006.

LIMA, Fabio Barbosa de. Parecer bom $\mathbf{X}$ parecer justo - o pedido de desculpas na gestão da imagem nas interações midiáticas. 2012. 128f + anexos. Dissertação (Mestrado em Língua Espanhola e Literaturas Espanhola e Hispano-Americana) Universidade de São Paulo, São Paulo, 26 jul. 2012.

LIPOVETSKY, Gilles. A sociedade humorística. In: Lipovetsky, Gilles. A Era do Vazio: ensaios sobre o individualismo contemporâneo. Barueri: Manole, 2005, p. 111-144. [A primeira edição foi em 1983 - A tradução do português foi feita a partir da edição de 1993.]

LOPES, Felipe. Futebol e poder: Reflexões sobre a tese do "ópio do povo". In: Revista Espaço Ética: Educação, Gestão e Consumo. São Paulo, Ano I, N. 02, mai./ago. de 2014, p. 136-144.

MACHADO, Irene. Gêneros discursivos. In: BRAIT, Beth. (Org.). Bakhtin: conceitoschave. São Paulo: Contexto, 2005.

MAGALHÃES, Henrique. Humor em pílulas: a força criativa das tiras brasileiras. João Pessoa: Marca de Fantasia, 2006.

MAINGUENEAU, Dominique. Análise de textos de comunicação. São Paulo: Cortez, 2001.

MAINGUENEAU, Dominique. Discours de savoir, communautés de savants. In: EHLICH, Konrad. Mehrsprachige Wissenschaft - europaische Persoektiven. 2002. Disponível em: <http://www.euro-sprachenjahr.de/Maingeneau.pdf>. Acesso em: 16 mai. 2015. 
MAINGUENEAU, Dominique. O discurso literário. Tradução Adail Sobral. São Paulo: Contexto, 2006.

MAINGUENEAU, Dominique. "Le tour ethnolinguistique de l'analyse du discours" In: Langages $n^{\circ} 105,114-125,1992$.

MAINGUENEAU, Dominique. Gênese dos discursos. Tradução Sírio Possenti. São Paulo: Parábola, 2008a.

MAINGUENEAU. Dominique. Cenas da enunciação. Organização: Sírio Possenti, Maria Cecília Péres Souza-e-Silva. São Paulo: Parábola, 2008b.

MAINGUENEAU, Dominique. Ethos, cenografia, incorporação. Tradução Sírio Possenti. In: Amossy, Ruth (Org.). Imagens de si no discurso: a construção do ethos. São Paulo: Contexto, 2008c.

MAINGUENEAU, Dominique. Doze conceitos em Análise do Discurso. São Paulo: Parábola, 2010.

MAINGUENEAU, Dominique. Frases sem texto. Tradução: Sírio Possenti et alii. São Paulo: Parábola, 2014.

MARCUSCHI, Luiz Antônio. Produção textual, análise de gêneros e compreensão. São Paulo: Parábola, 2008.

MARQUES, José Carlos (Org.). A Copa das Copas? Reflexões sobre o Mundial de Futebol de 2014 no Brasil. São Paulo: Edições Ludens, 2015.

MARQUES DE MELO, José. Quem tem medo de quadrinhos?. In: LUYTEN, Sonia Bibe (Org.). Cultura pop japonesa. São Paulo: Hedra, 2005, p. 131-135.

MARTIGNONE, Hernán \& PRUNES, Mariano. Historietas a Diario: las tiras cómicas argentinas de Mafalda a nuestros días. Buenos Aires: Libraría, 2008.

MARTÍN-BARBERO, Jesús. De los medios a las mediaciones. Comunicación, cultura y hegemonía. Naucalpan: Editorial Gustavo Gili, 1991.

MATTE BON, Francisco. Gramática comunicativa del español: de la idea de la lengua - tomo II. Madri: Edelsa, 2010.

MELLO, Renato de \& VALE, Rony Petterson Gomes. Humor, semiolinguística e piadas: uma proposta de análise. Caletroscópio - Revista do Programa de Pós-graduação em Letras: Estudos da Linguagem da Universidade Federal de Ouro Preto, v. 1. n. 1, jul./dez. 2012.

MENDONÇA, Márcia Rodrigues de Souza. Um gênero quadro a quadro: a história em quadrinhos. In: DIONISIO, Angela Paiva, MACHADO, Anna Rachel \& BEZERRA, Maria Auxiliadora. (Orgs.). Gêneros textuais e ensino. São Paulo: Parábola, 2a reimpressão, 2010, p. 209-224. 
MENEZES, Andreia dos Santos. Entre pátrias, pandeiros e bandoneones: O embate entre vozes marginais e disciplinadoras em composições de samba e tango (1917-1945). 2012. 309f. Tese (Doutorado em Língua Espanhola e Literaturas Espanhola e HispanoAmericana) - Universidade de São Paulo, São Paulo, 2012.

MENÓN. Lorena Mariel. A vida como ela é no mundo de faz de contas: uma análise enunciativa-discursiva das revistas Gente e Contigo!. 2016. 363f. Tese (Doutorado em Língua Espanhola e Literaturas Espanhola e Hispano-Americana) - Universidade de São Paulo, São Paulo, 29 de abr. 2016.

MERENSON, Silvina. Integración, estereotipos y Mercosur. In: GRIMSON, Alejandro (Org.). Pasiones Nacionales. Política y cultura entre Brasil y Argentina. Buenos Aires: Edhasa: 2007.

MEYER, Diogo Corrêa. "A Argentina é o nosso eterno outro": a construção de identidades nacionais e regionais na Copa Libertadores da América segundo os periódicos. 2014. 67 f. Monografia (Bacharel em Ciências Sociais) - Escola de Filosofia, Letras e Ciências Humanas, Universidade Federal de São Paulo, Guarulhos, 2014.

MINOIS, Georges. Historia de la Risa y de la Burla. De la Antigüedad a la Edad Media. Tradução de Jorge Brash. México D.F.: Ficticia Editorial, 2015. [Edição em francês, 2000.]

MORAIS, Marília Brandão Lemos. Humor e psicanálise. In: Estudos de Psicanálise. Belo Horizonte, n. 31, p. 114-124, out. 2008. Disponível em <http://pepsic.bvsalud.org/scielo.php?script=sci_arttext\&pid=S010034372008000100014\&lng=pt\&nrm=iso >. Acesso em: 20 jul. 2017.

MORETTI, Fernando. A história das tiras. In: FAOZA; ORLANDELI, Walmir Americo e MESSINA, Salvador. Central de tiras. São Paulo: Via Lettera, 2003.

MOURILHE SILVA, Fábio Luiz Carneiro. O Quadro nos Quadrinhos. Rio de Janeiro: Multifoco, 2010.

MOYA, Álvaro de. Shazam! São Paulo: Perspectiva, 1970.

NATARELLI, Natália. "O riso continua sendo a arma dos impotentes", diz professor da FFLCH. Jornal do Campus, São Paulo, 24 set. 2010. Disponível em: <http://www.jornaldocampus.usp.br/index.php/2010/09/o-riso-continua-sendo-a-armados-impotentes-diz-professor-da-fflch/>. Acesso em: 12 fev. 2016.

NEPOMUCENO, Terezinha. Sob a ótica dos quadrinhos: uma proposta textualdiscursiva para o gênero tira. 2005. 143 f. Dissertação (Mestrado em Linguística) Instituto de Letras e Linguística, Universidade Federal de Uberlândia, Uberlândia, 2005.

NINIO, Marcelo. Nacionalismo marca volta da Copa ao país após 57 anos. Folha de $\boldsymbol{S}$. Paulo. São Paulo, 31 out. 2007. Disponível em: <http://www1.folha.uol.com.br/fsp/esporte/fk3110200702.htm>. Acesso em: 11 jan. 2016. 
NUNES, Augusto. Estamos cansados de Campeonatos Morais. Revista Placar - edição número 694 - 9 set.1983. São Paulo: Abril, p.33.

OLIVEIRA, Renaje. Quando Ele vira notícia: Don Diego Maradona e a construção da identidade argentina no jornal Zero Hora. Revista Alceu, v. 6. n. 12. p. 126 a 139 janeiro a junho de 2006. Rio de Janeiro, PUC-Rio. Disponível em: $\langle$ http://revistaalceu.com.puc-rio.br/media/alceu n12 Oliveira.pdf $>$. Acesso em: 01 jul. 2017.

PALACIOS, Cristian. Algunos alcances de la perspectiva multimodal para el estudio de lo cómico y lo humorístico. Signo y Seña, no 23, junho de 2013, pp. 257-278. Disponível em: <http://revistas.filo.uba.ar/index.php/sys/index >. Acesso em: 13 set. 2015.

PERDIGÃO, Paulo. Anatomia de uma derrota. São Paulo: L\&PM, 1986.

POSSENTI, Sírio. Humor, língua e discurso. São Paulo: Contexto, 2010.

POSSENTI, Sírio. O discurso do humor: temas técnicas e leituras. In: POSSENTI, Sírio. Os humores da língua. Análises Linguísticas de Piadas. Campinas: Mercado de Letras, $6^{\text {a }}$ reimpressão: $1998-2008$, p. 25-40.

POSSENTI, Sírio. Questões para analistas do discurso. São Paulo: Parábola, 2009.

RAJAGOPALAN, Kanavillil. O Conceito de Identidade em Lingüística: é chegada a hora para uma reconsideração radical. In: SIGNORINI, Inês (Org). Língua(gem) e Identidade. Campinas: Mercado de Letras/Fapesp, 1998.

RAMOS, Paulo. Histórias em Quadrinhos: um novo objeto de estudos. In: Estudos Linguísticos. n. 35, 2006 a, p. 1574-1583. Disponível em: <http://www.gel.org.br/estudoslinguisticos/edicoesanteriores/4publica-estudos2006/sistema06/563.pdf >. Acesso em: 20 nov. 2013.

RAMOS, Paulo. A leitura dos quadrinhos. São Paulo: Contexto, 2009.

RAMOS, Paulo. Bienvenido: um passeio pelos quadrinhos argentinos. Campinas: Zarabatana Books, 2010.

RAMOS, Paulo. Faces do humor: uma aproximação entre piadas e tiras. Campinas: Zarabatana Books, 2011a.

RAMOS, Paulo. Tiras, Gênero e Hipergênero: Como os Três Conceitos se Processam nas Histórias em Quadrinhos. In: Anais do VI Siget - Simpósio Internacional de Estudos dos Gêneros Textuais, 2011, Natal. VI Siget - Simpósio Internacional de Estudos dos Gêneros Textuais, 2011b.

RAMOS, Paulo. Revolução do gibi: a nova cara dos quadrinhos no Brasil. São Paulo: Devir, 2012a.

RAMOS, Paulo. Tiras Livres: Um Gênero em Processo de Consolidação. Trabalho apresentado no GP de Produção Editorial, X Encontro dos Grupos de Pesquisas em 
Comunicação, evento componente do XXXIII Congresso Brasileiro de Ciências da Comunicação. <http://www.intercom.org.br/papers/nacionais/2010/resumos/R5-19761.pdf>. Acesso em 13 dez. 2013.

RAMOS, Paulo. Tira ou tirinha? Um gênero com nome relativamente instável. In: Estudos Linguísticos. n. 42 (3), 2013 a, p. 1267-1277. <http://gel.org.br/estudoslinguisticos/volumes/42/el42 v3 set-dez 26 v2.pdf> Acesso em: 20 nov. 2013.

RAMOS, Paulo. The gradual nationalization of comic strips in Brazilian newspapers. International Journal of Comic Art. Drexel Hill: spring/summer, v. 17, n. 1. p. 465477, 2015a.

RAMOS, Paulo. Piadas para ver: o uso da imagem como recurso de humor em tiras cômicas. In: CARMELINO, Ana Cristina (Org.). Humor: eis a questão. São Paulo: Cortez, 2015b, pp 137 a 153.

RASKIN, Victor. Semantic Mechanisms of Humor. Dordrecht: D. Reidel Publishing Company, 1985.

REAL ACADEMIA ESPAÑOLA e ASOCIACIÓN DE ACADEMIAS DE LA LENGUA ESPAÑLA. Nueva gramática de la lengua española. Manual. Madri: Espasa, 2010.

REYES, Graciela. La pragmática lingüística. El estudio del uso del lenguaje. Barcelona, Montesinos, 1990.

REYES, Graciela. El abecé de la pragmática. Madri: Arco/Libros, 1998.

REYES, Graciela; BAENA, Elisa e URIOS, Eduardo. Ejercicios de pragmática. Volumes I e II. Madri, Arco/Libros, 2005.

RIBEIRO, Carlos Henrique de Vasconcellos et al. Representações sociais de jornalistas argentinos e brasileiros sobre Maradona e Romário. Movimento (ESEFID/UFRGS), Porto Alegre, p. 205-233, mai. 2012. Disponível em: <http://www.seer.ufrgs.br/index.php/Movimento/article/view/24278/19071>. Acesso em: 06 jul. 2017.

ROCO JUNIOR, Ary José. Apresentação. In: MARQUES, José Carlos (Org.). A Copa das Copas? Reflexões sobre o Mundial de Futebol de 2014 no Brasil. São Paulo: Edições Ludens, 2015. p. 11-12.

ROJO, Roxane. Gêneros de discurso /texto como objeto de ensino de línguas: um retorno ao trivium? In: SIGNORINI, I. (Org.). [Re]discutir texto, gênero e discurso. São Paulo: Parábola, 2008, p. 73-108.

ROJO, Roxane Helena Rodrigues. Gênero do discurso e gêneros textuais: questões teóricas e aplicadas. In: MEURER, José Luiz; MOTTA-ROTH, Désirée; BONINI, Adair. Gêneros: teorias, métodos e debates. São Paulo: Parábola, 2005, p. 184-207. 
RUIZ GURILLO, Leonor. La linguística del humor en español. Madri: Arco/Libros, 2012.

RUSSO, Martín Ernesto. A voz do torcedor e do "hincha" na narração de gol no futebol do Brasil e da Argentina. 2013. 143f. Dissertação (Mestrado em Língua Espanhola e Literaturas Espanhola e Hispano-Americana) - Universidade de São Paulo, São Paulo, 21 mar. 2013.

SALGADO, Luciana Salazar; GATTI, Márcio Antônio. Personagens infantis de tiras cômicas em suportes diversos: uma questão de circulação, aforização e estereotipia. DELTA: Documentação e Estudos em Linguística Teórica e Aplicada. ISSN 1678-460X, [S.1.], v. 29, n. 3, dez. 2013. ISSN 1678-460X. Disponível em: <https://revistas.pucsp.br/index.php/delta/article/view/19341/14355>. Acesso em: 01 ago. 2017.

SARMIENTO, Juan Facundo. Elementos culturais argentinos nas HQ de Liniers: uma contribuição para a formação intercultural do professor de ele. 2013. $111 \mathrm{f}$. Dissertação (Mestrado em Língua e Cultura) - Universidade Federal da Bahia, Salvador, 2013.

SAID, Edward. W. Orientalismo. O oriente como invenção do Ocidente. Tradução Rosaura Eichenberg. São Paulo, Companhia das Letras, 2007.

SILVA, Bárbara Zocal da. As tiras de Mafalda no Brasil: tradutores e traduções. 2015. 229f. Dissertação (Mestrado em Língua Espanhola e Literaturas Espanhola e HispanoAmericana) - Universidade de São Paulo, São Paulo, 28 set. 2015.

SILVA, Fábio Luiz Carneiro Mourilhe. O Quadro nos Quadrinhos. Rio de Janeiro: Multifoco, 2010.

SILVA, Rafael Souza. Diagramação: o Planejamento Visual Gráfico na Comunicação Impressa. São Paulo: Summus, 1985.

SILVA, Sandra Falcão da. O riso em Mainardi: um estudo sobre os mecanismos linguístico-discursivos do humor nas crônicas de Diogo Mainardi. $2009.178 \mathrm{f}$. Dissertação (Mestrado em Língua Portuguesa) - Pontifícia Universidade Católica de São Paulo.

SILVA, Sandra Falcão da. Humor no Dessin de Presse: leitura de um discurso universal a serviço da alteridade em FLE. 2015. 387f. Tese (Doutorado em Estudos Linguísticos, Literários e Tradutológicos em Francês) - Universidade de São Paulo, São Paulo, 07 mai. 2015.

SILVA, Tomaz Tadeu da. A produção social da identidade e da diferença. In (org.) SILVA, Tomaz Tadeu da. Identidade e diferença: a perspectiva dos Estudos Culturais. Rio de Janeiro: Vozes, 1997/2014. 
SPRECHER, Roberto Von. Estudio de la historieta como campo: Las luchas por la construcción de lo nuevo y de lo viejo, en Argentina, desde los noventa. In: VI Jornadas de Sociología de la UNLP, 9-10 dez. 2010, La Plata, Argentina. In: Memoria Académica. Disponível em: <http://www.memoria.fahce.unlp.edu.ar/trab_eventos/ev.5712/ev.5712.pdf>. Acesso em: 15 jan. 2017.

STEFANO, Mariana di. Anarquismo de la argentina. Una comunidad discursiva. Buenos Aires: Cabiria, 2015.

STEIMBERG, Óscar. Leyendo historietas - textos sobre relatos visuales y humor gráfico. Buenos Aires: Eterna Cadencia, 2013.

STEIMBERG, Óscar. Sobre algunos temas y problemas del análisis del humor gráfico. Signo y Seña, n. 12, Instituto de Lingüística, Facultad de Filosofía y Letras, UBA, Buenos Aires, p. 99-118, 2001 (distribuido en 2002).

TRAVAGLIA, Luiz Carlos. Uma introdução ao estudo do humor pela lingüística. DELTA - Revista de Documentação de Estudos em Lingüística Teórica e Aplicada, São Paulo, v. 6, n. 1, p. 55-82, 1990.

VERGUEIRO, Waldomiro. "A pesquisa em quadrinhos no Brasil: a contribuição da universidade". In LUYTEN, Sonia Bibe (Org.). Cultura pop japonesa. São Paulo: Hedra, 2005, p. $15-26$.

VERGUEIRO, Waldomiro \& SANTOS, Roberto Elísio dos. A pesquisa sobre histórias em quadrinhos na Universidade de São Paulo: Análise da Produção de 1972 a 2005. Texto apresentado no VII Congresso da Asociación Latinoamericana de Investigadores de Comunicación, São Leopoldo, Rio Grande do Sul, em jul. 2006.

VIVERO GARCÍA, María Dolores. Humor y subversión de la doxa. El humor del 15-M contra el neo-caca-pipi-talismo. In: Revista Viento Sur, ${ }^{\circ} 118$, ano XX, setembro 2011, p. 107-115.

WISNIK, José Miguel. Veneno Remédio: O futebol e o Brasil. São Paulo: Companhia das Letras, 2008.

WOODWARD, Kathryn. Identidade e diferença: uma introdução teórica e conceitual. Tradução Tomaz Tadeu da Silva. In: SILVA, Tomaz Tadeu da. (Org.). Identidade e diferença: a perspectiva dos Estudos Culturais. Rio de Janeiro: Vozes, 1997/2014. 


\section{APÊNDICE}

\section{Biografias dos autores das tiras analisadas}

\section{André Dahmer}

André Dahmer Pereira nasceu na cidade do Rio de Janeiro em 14 de setembro de 1974. Desenhista, quadrinista e cartunista, tem como principal criação a tira Malvados, publicada pelo jornal Folha de S. Paulo. Seu trabalho começou a se destacar na Internet em 2001, com o site malvados.com.br, que chegou a atingir dois milhões de visualizações por mês. O sucesso virtual o levou para impresso. Malvados são dois seres que não tem uma definição muito clara, alguns consideram que são girassóis ou margaridas, outros dizem que são filhotes de leão ou simplesmente "flores do mal"; um é o Malvadinho e o outro o Malvadão. Enquanto o primeiro da dupla é o que mais sofre, o segundo é o responsável pelas críticas mais ácidas, por vezes se aproximando do chamado politicamente incorreto. Além dessa criação Dahmer também é autor do personagem Emir Saad, ditador do fictício reino do Ziniguistão, governado ditatorialmente de maneira sádica e egocêntrica, inclusive com tortura. É dele também as tiras “Apóstolos, a série", que narra a história de Jesus Cristo fazendo críticas ao cristianismo e à Igreja Católica. Além da Folha de S.Paulo, já publicou no Jornal do Brasil, O Globo, Piauí, Sexy Premium, Caros Amigos e no portal G1. É autor dos livros "Malvados" (Gênesis, 2005), "O livro negro de André Dahmer" (Desiderata, 2007), "Ninguém Muda Ninguém" (Flâneur. 2011), "Rei Emir Saad: O monstro de Zazanov" (Barba Negra, 2011), "A Coragem do Primeiro Pássaro" (Lote 42, 2015), entre outros.

Fontes consultadas

$<$ http://malvados.com.br/>. Acesso em 14/07/2017.

<http://g1.globo.com/Noticias/PopArte/0,,MUL100648-7084,00-

$\underline{\text { ANDRE+DAHMER+SE+JUNTA+AO+TIME+DE+QUADRINISTAS+DO+G.html>. }}$

Acesso em 14/07/2017.

$<$ https://malvados.wordpress.com/2009/07/31/revista-mais-soma/> Acesso em 14/07/2017.

$<$ http://www.a-arca.com.br/2006/10/entrevista-exclusiva-andre-dahmer-o-pai-dosmalvados/> Acesso em 14/07/2017. 


\section{Alexandra Moraes}

Alexandra Moraes é jornalista. Nascida em 1982, atuOU como editora-adjunta na Folha de S.Paulo, jornal que publica a sua principal criação: O Pintinho. O personagem surgiu em 2009, logo depois do nascimento do seu filho Benjamin. As tiras traziam os possíveis diálogos que ela poderia ter com ele no futuro. As primeiras foram criadas no Microsoft Paint e distribuídas para um grupo de amigos, via e-mail. O sucesso foi imediato e foi ganhando cada vez mais adeptos. Alexandra diz que adora trabalhar no Paint, pois "era minha ferramenta preferida quando eu era criança e fazia desenho, quadrinhos e jornal pro meu cachorro. Ele está em todo lugar, é fácil e simples, amacia o caminho pra quem é mais limitado, feito eu". O Pintinho está sempre dialogando com a sua mãe sobre as mais variadas questões, principalmente aquelas que se vinculam com o cotidiano das pessoas; também há um Nuget, que faz o papel do pai do personagem. Uma seleção de sua produção foi lançada pela Lote 42 , com o título "O Pintinho - mais um filho de mãe brasileira".

Fontes consultadas

<http://revistagalileu.globo.com/Revista/noticia/2013/12/alexandra-moraes.html >. Acesso em $14 / 07 / 2017$.

<http://revistatrip.uol.com.br/tpm/o-pintinho $>$. Acesso em 14/07/2017.

<http://www.lote42.com.br/pintinho/o-pintinho---autora.html>. Acesso em 14/07/2017.

\section{Allan Sieber}

Allan Sieber nasceu na cidade de Porto Alegre em 1972. É filho do desenhista publicitário Jouralbo Sieber, que o ensinou a gostar de quadrinhos. Allan Sieber tem como uma de suas principais influências artísticas a obra de Robert Crumb, mestre e um dos fundadores do movimento underground dos quadrinhos estadunidenses. Também foi influenciado pelas revistas da Circo Editorial, responsável pela edição das obras de Angeli, Glauco e Laerte. Entre suas tiras publicadas pela Folha de S. Paulo destacam-se para "Vida de Estagiário", "Preto no Branco", "The Mommy's Boys" e "Bifaland, a Cidade Maldita”, que inicialmente apareceu no jornal O Estado de S.Paulo. O humor de Sieber é caracterizado principalmente pelo sarcasmo, às vezes pela heresia, pela escatologia e a crítica comportamental. Ele também trabalhou como editor da revista “Glória Glória Aleluia”, pela qual recebeu em 1995 o Troféu HQ Mix como melhor fanzine e, três anos depois, o de melhor Revista Independente. Sua atuação não se limita à mídia impressa, realiza também filmes de animação. Seu curta-metragem "Deus é Pai”, 
em 1999, venceu o Prêmio da Crítica e o Prêmio Especial do Júri no Festival de Gramado. Depois dessa bem sucedida experiência na área, criou as animações "Os Idiotas Mesmo" (2000), “Onde Andará Petrucio Felker?” (2001), "Santa de Casa” (2006) e “Animadores" (2008). É autor dos livros “As Piadas Vagabundas do Steven" (1997), "As Últimas Palavras" (1999), "Sem Comentários" (2005), “Assim Rasteja a Humanidade" (2006), "É Tudo Mais ou Menos Verdade" (2009), "Ninguém me Convidou” (2010), em parceria com Jouralbo Sieber; entre outros.

Fontes consultadas

<https://allansieber.blogosfera.uol.com.br/2017/03/31/bifaland-181/>. $\quad$ Acesso em 14/07/2017.

<http://www.panoramamercantil.com.br/o-humor-so-deve-fazer-rir-allan-sieber-cartunistaanimador-ilustrador-e-quadrinista/>. Acesso em 14/07/2017.

<http://www2.uol.com.br/allansieber/quadrinhos.htm>. Acesso em 14/07/2017.

$<$ http://www.panoramamercantil.com.br/o-humor-so-deve-fazer-rir-allan-sieber-cartunistaanimador-ilustrador-e-quadrinista/>. Acesso em 14/07/2017.

\section{Caco Galhardo}

O cartunista brasileiro Caco Galhardo, cujo nome completo é Antônio Carlos Galhardo, nasceu na cidade de São Paulo. Sua principal criação é a tira Os Pescoçudos, publicada na Folha de S.Paulo e, durante alguns anos, também no jornal O Dia, do Rio de Janeiro. Nela, ele apresenta nosso cotidiano, mas de forma um tanto surreal. Galhardo começou sua carreira nos anos 1980 publicando fanzines, quando estudava na Comunicação na Faap. Além de quadrinista também atuou como redator na MTV, de 1993 a 1997, escrevendo campanhas voltadas à cidadania, tais como contra a violência e prevenção à Aids. Ainda como redator colaborou na televisão com os programas "Casseta" e "Planeta Urgente", da Rede Globo. Também já fez animação para Nickelodeon, Unicef e Festival Videobrasil. Atualmente, tem trabalhado como roteirista adaptando principalmente quadrinhos para formatos televisivos e cinematográficos.

Fontes consultadas

<https://cacogalhardo.wordpress.com/about/>. Acesso em 14/07/2017.

<https://omelete.uol.com.br/quadrinhos/entrevista/omelete-entrevista-caco-galhardo/>.

Acesso em 14/07/2017.

< http://www.editorapeiropolis.com.br/biografia/?autor=139>. Acesso em 14/07/2017. 


\section{Carlos Loiseau (Caloi)}

Carlos Loiseau (Caloi) nasceu em Salta, capital da província argentina do mesmo nome, em 9 de novembro de 1948, mas se criou em Adrogué, cidade da região metropolitana de Buenos Aires, Argentina.

Suas primeiras publicações aconteceram na revista Tía Vicenta, em 1966 e a partir desse momento não parou mais de publicar até seu falecimento. A revista em que debutou foi fechada nesse mesmo ano por Juan Carlos Onganía, militar alçado à condição de Presidente do país após um golpe de estado das Forças Armadas. Logo em seguida, em 1968, Caloi passou a integrar a equipe de quadrinistas que publicavam no jornal Clarín onde permaneceu por 44 anos, sem abrir mão de dedicar-se a outras empreitadas.

Caloi foi um autor profícuo que atuou em diferentes meios e com diferentes gêneros. Produziu para publicidade, levou seu personagem Clemente para a televisão, para protagonizar um programa de bonecos com seu nome como título e ele mesmo apresentou o programa Caloi en su tinta, dedicado à divulgação do cinema de animação.

Caloi faleceu em 08 de maio de 2012, aos 63 anos.

\section{Clemente e o episódio de "los papelitos"}

Clemente nasceu nas páginas do Clarín em 1973, primeiramente como coadjuvante do personagem principal Bartolo, um motorneiro. Mas o carisma do coadjuvante superou o protagonista e Clemente foi alçado à condição de protagonista. Trata-se de uma espécie de pássaro sem asas, que, entre outras características humanas, era torcedor do time Boca Juniors e várias de suas histórias têm o futebol como tema.

Durante a Copa de 1978, ocorrida na Argentina e vencida também pelo país, Clemente - e por conseguinte, Caloi - protagonizou um enfrentamento com orientações que emanavam do governo, uma ditadura das mais ferozes, em um episódio que o converteria em símbolo do torcedor argentino da seleção. Conforme Ramos (2010, p.40), durante o Mundial os mandatários do país empreenderam uma campanha contra um hábito dos argentinos durante os jogos em estádios: jogar papeizinhos picados. $\mathrm{O}$ argumento era que isso sujava os estádios, sujeira que seria associada aos argentinos, e isso "no quedaba bien" considerando que se tratava de um evento internacional transmitido para o mundo inteiro. Um dos porta-vozes da campanha era o locutor José María Muñoz que em suas intervenções dizia "no hay que tirar papelitos". Caloi, em suas tiras diárias passou a colocar personagem Clemente questionando “¿cómo no vamos a tirar papelitos si los argentinos tiramos papelitos?". Instaurou-se então a chamada "guerra de los papelitos": a 
população atendeu ao chamado de Clemente e nos estádios nunca houve tantos papeizinhos picados. Cada vez que aparecia a seleção argentina em campo, nos painéis eletrônicos dos estádios - controlados pela Fifa e não pelos governantes - surgia a figura de Clemente pedindo “ $¡ T$ Tiren papelitos muchachos!” e no jogo final contra a Holanda o gramado parecia estar pintado de branco. Como dissemos, Caloi faleceu em maio de 2012, mas Clemente ainda está fortemente associado à participação argentina nas Copas, prova disso é sua presença em produções de diferentes autores publicados após o vicecampeonato da seleção argentina de futebol em 2014.

Fonte consultada

< http://www.todohistorietas.com.ar/Clemente.htm>. Acesso em 31/05/2015.

\section{Diana Raznovich}

Nasceu no dia 12 de maio de 1945 em Buenos Aires. É neta de russos e austríacos. Estudou literatura na Universidade de Buenos Aires. Durante a ditadura militar argentina, com o desaparecimento de Ernesto Clusellas, seu primeiro marido, viveu exilada na Espanha de 1976 a 1981. Diana dedica-se ao teatro e ao humor gráfico, sendo a criadora de Donatela, tira que durante alguns anos substituiu Clemente, após a morte de Caloi. Ela foi a primeira mulher a publicar uma tira na última página do Clarín. Donatela é uma mulher de 40 anos com uma filha adolescente, família e trabalho para cuidar. Segundo a autora, a personagem Donatela "não é uma mulher ideal, mas tem seus ideais. Ela quer viver em um mundo menos corrupto, mais justo e democrático. Sonha com uma Argentina menos isolada e mais integrada ao mundo. Quer um país melhor para sua filha. Vive na correria constante de toda mulher entre o seu trabalho e a casa". Como dramaturga destacam-se as seguintes obras: "Casa Matriz", "Jardín de Otoño", "De atrás para adelante" e "De la cintura para abajo". Também foi diretora da Argentores (Sociedade Geral de Autores da Argentina), organismo de defesa dos direitos autorais dos profissionais de teatro, cinema, rádio e televisão.

Fontes consultadas

<https://www.clarin.com/sociedad/llega-clarin-historieta-familiadonatela 0 ByBgA51hDXl.html>. Acesso em 14/07/2017.

<http://www.lanacion.com.ar/1608449-diana-raznovich-el-humor-es-una-cosa-seria-ydesestabilizadora>. Acesso em 14/07/2017. 


\section{Dobal}

Felipe Miguel Ángel Dobal é um dos mais longevos desenhistas de humor da Argentina. Nasceu em Puan, na província de Buenos Aires, em 7 de janeiro de 1923. Iniciou a trabalhar em 1939 no jornal El Atlántico, de Bahia Blanca, com somente 16 anos, produzindo uma tira chamada "Atualidade por Dobal". Depois disso não parou mais, passou pela revista Don Fulgencio e dali para o Clarín em 1958. Nesse jornal criou a tira "De la crónica diária", em 1972, publicada até 2003. Nela fazia um painel do cotidiano do povo argentino marcado por um nacionalismo e catolicismo um tanto conservador. Também colaborou com o La Razón, Crónica, El Hogar, Mundo Deportivo e o chileno Pobre diablo.

Fontes consultadas

<https://www.clarin.com/sociedad/humor-dobal-despide-

contratapas_0_BkR7OregAYl.html>. Acesso em 14/07/2017.

<https://confluenze.unibo.it/article/viewFile/3441/2797>. Acesso em 14/07/2017.

<http://www.temperleyweb.com.ar/biodobal.htm>. Acesso em 14/07/2017.

\section{Glauco}

Glauco Villas Boas nasceu em Jandaia do Sul (PR) em 10 de março de 1957 e morreu em Osasco no dia 12 de março de 2010. Juntamente com Angeli e Laerte, formava o que se chamou "a santíssima trindade dos quadrinhos brasileiros". Seu primeiro trabalho em tira foi publicado no jornal Diário da Manhã, na cidade de Ribeirão Preto. Dono de grande criatividade construiu uma galeria de tipos inesquecíveis como Casal Neuras, Doy Jorge, Dona Marta, Zé do Apocalipse e Geraldão. Este último foi criado em 1981, depois de Glauco ter lido a obra "A Erva do Diabo", do escritor peruano Carlos Castañeda. O personagem - que chegou a ter uma revista própria de 1987 e 1990 - é um sujeito que tem por volta de 30 anos, anda nu pela casa constantemente, mora com a mãe (com quem está sempre discutindo e assediando), é viciado em cigarros, bebidas e remédios. Pelo seu talento, Glauco foi premiado no Salão Internacional de Humor de Piracicaba e na $2^{\mathrm{a}}$ Bienal de Humorismo y Gráfica de Cuba, também trabalhou como roteirista da TV Pirata e TV Colosso, programas da Rede Globo.

Fontes consultadas:

<http://www2.uol.com.br/glauco/queme.shtml>. Acesso em 14/07/2017.

RAMOS, Paulo. Revolução do gibi: a nova cara dos quadrinhos no Brasil. São Paulo: Devir, 2012a. 


\section{Pryscila Vieira}

Nasceu em Curitiba. Sua personagem principal é Amely, uma boneca inflável que ganha vida própria com sentimentos e pensamentos, como uma mulher de verdade. O nome foi inspirado no samba antológico "Ai Que Saudades da Amélia", composto em 1942 por Ataulfo Alves e Mário Lago, exemplo ultrapassado de mulher submissa. Já a personagem Amely, "a primeira boneca inflável feminista do mundo", foi criada em 2005 ganhando as páginas de jornais como Metro Internacional e Folha de S.Paulo, além do site UOL. Dez anos depois do seu nascimento, Amely foi motivo de exposições em vários locais, servindo para que fosse debatido o papel da mulher na sociedade atual. Uma coletânea dos dez anos da tira foi lançada no livro "Amely, uma mulher de verdade" (Contenido), com prefácio do cartunista Ziraldo e comentários da própria autora. Pryscila Vieira possui um canal no Youtube chamado Prysciladas, no qual apresenta e compartilha com o seu público suas ideias e criações.

Fontes consultadas

<http://www.amelyreal.com/.> Acesso em 14/07/2017.

$<$ http://ladyscomics.com.br/entrevista-pryscila-vieira > Acesso em 14/07/2017.

$<$ http://www.jornalopcao.com.br/colunas-e-blogs/imprensa/a-historia-da-criacao-da-musicaamelia-por-mario-lago-e-ataulfo-alves-33004/> Acesso em 14/07/2017.

\section{Sendra}

Fernando Javier Sendra nasceu na cidade de Mar del Plata no dia 08 de setembro de 1949. Chegou a cursar durante três anos Engenharia na Universidade de Buenos Aires, mas abandonou o curso para dedicar-se ao desenho. Começou a publicar em 1973 na revista Siete Días, indo depois para Jocker, Para Ti e La Semana. A principal criação do cartunista é o personagem Matías, publicado nas páginas do Clarín. O material produzido já rendeu a Sendra mais de vinte livros. Em 2002, foi considerado um dos cinco melhores humoristas gráficos da Argentina, o que lhe rendeu o Prêmio Konex, um dos mais importantes da Argentina. O personagem Matías está reproduzido em uma estátua no Paseo de la Historieta em Buenos Aires.

Fontes consultadas

<http://www.todohistorietas.com.ar/matias.htm> Acesso em 14/07/2017.

<http://www.taringa.net/posts/imagenes/2311789/Yo-Matias---Sendra-Superpost.html>

Acesso em 14/07/2017. 


\section{Sergio Langer \& Rubén Mirá}

Sergio Langer (Buenos Aires, 1959) é arquiteto de formação, tendo destaque como desenhista. Trabalhou em inúmeros órgãos da imprensa argentina tais como Humor, Sex Humor, La Prensa, o jornal esportivo Olé, Clarín, Página12, revista Noticias, Los Inrockuptibles, Rolling Stone, Playboy, Mística, além das americanas Newsweek, Miami Herald, New York Newsday e Herald Tribune.

Rubén Mira (Avellaneda,1964) é roteirista e escritor. Sua ação não se limita a isso, sendo também um dos fundadores da cooperativa editorial Tantalia (1993), além de pertencer ao grupo de agitação cultural NO MATARÁS. É autor do romance Guerrilleros (una salida al mar para Bolívia)", editada pela Diada em 2007.

Langer e Mirá são os criadores de La Nelly, que foi publicada pela primeira vez na última página do Clarín em setembro de 2003. A produção rendeu a publicação de La Nelly argentiníssima, em dois volumes. A dupla já havia trabalhado antes, em 1999, na revista Mística e nos livros Burroughs para principiantes (2001) e Cervantes para principiantes (2005).

Referências:

$<$ http://edant.clarin.com/suplementos/libros/2006/03/10/1-01279406.htm> Acesso em $14 / 07 / 2017$.

<https://www.pagina12.com.ar/diario/suplementos/radar/9-3344-2006-10-27.html>

Acesso em 14/07/2017.

<http://www.elbailemoderno.com/2015/08/la-vida-es-bella-entrevista-a-sergio-langer/>

Acesso em 14/07/2017.

<http://www.efdeportes.com/autor/langer.htm> Acesso em 14/07/2017.

\section{Tabaré}

Tabaré Gómez Laborde, ou simplesmente Tabaré, nasceu em 21 de agosto de 1948 na cidade de La Paz, no Departamento de Canelones, no Uruguai. Começou sua carreia como desenhista de agências de publicidade, no início dos anos setenta, em Montevidéu, passando depois pelas revistas Despegue (1971), La Chacota (1972), La Bocha (1972) e Noticias (1976), todas na capital uruguaia. Como caricaturista tem grande destaque na imprensa argentina, principalmente pela tira "Diógenes y el Linyera", publicada desde 1977 no jornal Clarín. O primeiro personagem é um cachorro de raça indefinida e o segundo um vagabundo, sempre com as mesmas vestimentas, chapéu e os sapatos furados, ambos fazem uma sátira da realidade política e social pelo ponto de vista dos 
marginalizados urbanos. Tabaré desenvolveu essa criação tendo como roteiristas Jorge Guinzburg, Carlos Abrevaya e Héctor García Blanco, porém desde 2008 ele mesmo ficou responsável pela criação total. Tabaré tem outros personagens como El cacique Paja Brava, com roteiro de Aquiles Fabregat, que mostra as desventuras sexuais de um cacique; e Don Chipote de la Pampa, roteiro também de Fabregat, uma paródia sobre "Dom Quixote de La Mancha" de Miguel de Cervantes e de "Martín Fierro", de José Hernández. Em 2003 recebeu o Prêmio Morosoli, concedido pela Fundação Lolita Rubial, do Uruguai, pela sua trajetória profissional.

Referências:

<http://www.museodeldibujo.com/obras muestras/artistas.php?ida=52\&a=G\%F3mez+La borde\%2C+Tabar\%E9+\%28Tabar\%E9\%29> Acesso em 14/07/2017.

<http://www.taringa.net/posts/comics/14766946/Tabare-Gomez-Laborde-Tabaredibujante-uruguayo.html> Acesso em 14/07/2017.

$<$ http://www.minutouno.com/notas/72133-diogenes-y-el-linyera-lloran-su-gran-maestrolas-vinetas > Acesso em 14/07/2017. 


\section{ENTREVISTA COM HERNÁN MARTIGNONE}

Hernán Martignone é co-autor de um livro que foi fundamental na concepção do projeto de pesquisa que redundou nesta tese. Em junho de 2017, na fase final de escrita deste trabalho, entramos em contato com ele para confirmar informações sobre mudanças que vínhamos detectando na página de humor do Clarín, onde são publicadas as tiras diariamente. Nossa percepção é que, especialmente após o falecimento de Caloi em 2010 e a interrupção da publicação de La Nelly, as produções que figuravam na página já não dialogavam tão fortemente com o noticiário local e haviam deixado de apresentar o tom crítico que marcara historicamente a página. A entrevista foi realizada por email em 02/07/2017 e, pela relevância das informações nela contidas, a reproduzimos integralmente, com a devida autorização do entrevistasdo.

Rosangela Dantas de Oliveira: la primera cuestión que le planteo es sobre los cambios de los últimos años en la página de humor del Clarín. La percepción que tengo es que perdió mucho de su calidad, a partir (a) del fallecimiento de Caloi; (b) de la descontinuidad de La Nelly (cuya razón exacta no logré descubrir). Es acertada mi percepción?

Hernán Martignone: en general te diría que sí, aunque habrá gente a la que todavía le gusta. Eso suele ser un poco subjetivo. Pero si uno compara con la contratapa del suplemento de Espectáculos del diario La Nación, puede decirse que el nivel en La Nación es más alto. Muchos opinan que Caloi también había bajado el nivel o que se repetía, pero yo creo que él se había sabido adaptar bien a los cambios (por ejemplo el uso del color, como comentan Gociol y Rosemberg en La historieta argentina. Una historia, Buenos Aires, Ediciones de la Flor, 2003[2000], p. 580) y sobre todo había pasado a usar (como muchas otras veces) la tira para dar su opinión (siempre mediatizada por el popular Clemente), opinión que además no solía coincidir con la línea editorial de Clarín (pasó durante el conflicto con el campo o con la reelección de Cristina Fernández de Kirchner). Quienes vinieron después (Diana Raznovich, Bernardo Erlich) están mucho más alineados con las opiniones del diario (no porque se adapten a ella, sino porque seguramente coinciden y ya). En ese sentido, volviendo a La Nación, con él pasaba algo parecido a lo que ocurre con varios de los humoristas que entraron en los últimos años (Tute, Max Aguirre, Diego Parés), que expresan habitualmente un punto de vista distinto al que se evidencia con claridad en las tapas y en las notas o los editoriales del diario. 
Y La Nelly (de Sergio Langer y Rubén Mira), de gran calidad y complejidad, además de ser una tira que trabajaba muy fuertemente con la realidad y con las noticias, y sobre todo con la política, siempre fue un bicho medio raro en esa contratapa (ya desde el estilo de dibujo "feísta" y barroco de Langer). De hecho, fue reemplazada por algo totalmente distinto, en forma y contenido, y sin ese peso político: la tira de Horacio Altuna, Es lo que hay (reality).

Sobre los motivos posibles de la finalización de La Nelly, te recomiendo leer $\begin{array}{llll}\text { completa esta entrevista } & \text { Sergio }\end{array}$ Langer: http://alrescatecomics.blogspot.com.ar/2016/05/sergio-langer-nelly-estabasatirizando.html

Ahí Langer dice, por ejemplo: "evidentemente alguien en el diario nos bancaba. Hasta que no nos bancaron más y dijeron "esta tira sacala" y chau. Y ellos están en este momento en un plan de recorte, entonces la tira les salía una guita. Están recortando gente, y la tira iba contra la corriente. No acompañaba este momento de "ahora vamos a darle duro con todo a los kirchneristas para que no se levanten nunca más". Ésa es la política actual. "Y estos tipos haciendo una historieta que se ríe de Macri". Eso es decadente. Porque a mí no me vengan con que la tira cumplió un ciclo y no mide, para mí es un chamuyo. Yo no lo creo."

Te paso también una nota de opinión (no sé cuánto te servirá, porque el tono es más de polémica que argumentativo, en una sección de la revista Comiqueando que se llama Por qué no me gusta) sobre la contratapa de Clarín en 2013: http://www.comiqueando.com.ar/columnas/por-que-no-me-gusta/la-contratapa-de$\underline{\text { clarin/ }}$

Y también podés leer otra nota de opinión sobre el reemplazo de Donatela de Diana Raznovich (por Tira y afloja, de Bernardo Erlich), tira que también tuvo muchos detractores (realmente el dibujo de Raznovich no terminada de fluir, de ser orgánico, se notaba mucho "corte y pega", por ejemplo, y los chistes tampoco eran buenos para mi gusto): http://www.comiqueando.com.ar/comic_clips/nueva-tira-para-clarin/

Acá te dejo además un link de la nota que le hicieron en el propio Clarín a la autora cuando estaba por comenzar con Donatela: https://www.clarin.com/sociedad/llegaclarin-historieta-familia-donatela_0_ByBgA51hDX1.html

También podría verse cierto desgaste en una tira como Diógenes el Linyera (de Tabaré, que hace unos años ya la realiza solo, mientras que en el pasado trabajaba con guionistas) o Yo, Matías (Sendra), quizás porque no se meten demasiado (ni demasiado 
directamente cuando lo hacen) con la actualidad (al igual que ocurre con el Macanudo de Liniers en La Nación). No es que sea necesario hacerlo, pero cuando las tiras llevan muchos años publicándose suele ser difícil mantenerlas solo con su "universo interno".

RDO: ¿en Argentina los diarios siguen siendo atractivos para los autores como espacio de trabajo? Porque en Brasil, por la crisis que afecta a los medios escritos en general, es un ámbito que está pasando por muchos cambios".

HM: por lo que he escuchado en diversas charlas con autores y autoras que trabajan en diarios, se trata de una fuente de trabajo estable, relativamente bien paga hasta donde sé, por lo que en general les parece una muy interesante salida laboral y un espacio que todavía genera mucha visibilidad para su trabajo.

El diario Tiempo Argentino, en los años del kirchnerismo, también dio espacio a un par de muy buenas tiras diarias (Canillitas, de Diego Agrimbau y Fernando Baldó, en el estilo de las tiras costumbristas con "continuará" que en su momento hiciera Carlos Trillo con Altuna o García Seijas; e Hija de vecina, de Caro Chinaski). También se publicó completa, como tira diaria, El Eternauta, que al concluir no fue reemplazada por otra tira. Ahora este diario está saliendo en papel solamente los domingos (lunes a sábado en la web: https://www.tiempoar.com.ar ) y se volvió una cooperativa manejada por sus empleados, luego de una serie de inconvenientes con los dueños tras la finalización del gobierno de CFK. Sigue publicándose ahí una tira semanal, de Ángel Mosquito, titulada Conurbania (pero no en la contratapa, sino en la sección cultural). Mosquito también publica una tira diaria para un diario que se publica solamente en la web, Diario Registrado, llamada Qué capo que debo ser: http://www.diarioregistrado.com/

\section{E-mail posterior recebido em 14/07/2017}

Hola! ¿Cómo andás?

Justo ayer vi Tiempo argentino en papel y al menos ahora están publicando Conurbania (de Ángel Mosquito) en la contratapa del cuerpo principal del diario. Te aviso por las dudas y porque te había puesto otra cosa.

Saludos! Hernán 


\section{ENTREVISTA COM CACO GALHARDO}

Em fevereiro de 2017 entramos em contato com o autor Caco Galhardo solicitando uma entrevista. À época, ainda não havíamos decidido o recorte que constituiría o corpus analisado nesta tese e estávamos intrigadas com um dado que se havia destacado no levantamento das tiras publicadas durante as Copas do Mundo de 1994 até 2014 nos jornais Clarín e Folha de S. Paulo: a republicação de produções. No recorte final, esse dado acabou não sendo explorado. Por outro lado, decidimos reproduzir a entrevista quase integralmente porque nela Galhardo faz reflexões importantes a respeito das condições de produção das tiras, sobre a efemeridade que tinham quando publicadas no veículo no formato tradicional em papel, bem como sobre o momento que atravessava como autor de produções gráficas. Trata-se da transcrição de uma conversa, realizada por Skype em 21/02/2017, e seu tom é bastante informal.

Rosângela Dantas de Oliveira: minha primeira pergunta é mais uma curiosidade. Todos os autores com que trabalho (tanto os daqui como os da Argentina) repetem tiras já publicadas em edições anteriores. Em algumas, as informações são atualizadas - nome dos países, de jogadores -, mas outras são publicadas da mesma forma que quatro anos antes. Exceto no caso do Tabaré - que publicou praticamente o mês inteiro de $2010 \mathrm{em}$ 2014 - a repetição eventual não me causou surpresa, pois sei do massacre que é produzir tiras diariamente e muitos estudos dessa área destacam isso. Mas um jornalista com quem comentei o achado se surpreendeu bastante e me levantou curiosidade com respeito à relação de vocês cartunistas/quadrinistas com os editores dos cadernos, com a liberdade que têm em decidir como ocupar o espaço de que dispõem, se se trata de uma solução emergencial ou se de repente é até intencional fazer uma tira menos datada para poder usá-la novamente.

CACO GALHARDO: é uma coisa que os jornais não gostam, não é uma política "Folha" aceitar tiras republicadas. Eu faço tiras há 20 anos na Folha, e vivemos um momento muito difícil de crise. Desenhar tira pra jornal hoje é quase uma coisa insustentável, porque nos anos 80 e 90 também ainda tinha essa coisa de você ter sua tira republicada. Ela saia na Folha ou em outros jornais, era o modelo americano, todas são sindicalizadas. E quem tem uma tira que estoura fica rico, sendo publicado em vários jornais. Aqui no Brasil, o Fernando Gonsales tinha uma coisa que ainda era invocado, mas hoje se fala em Laerte, em um e mais outro ou nenhum mais, só sai na Folha mesmo. 
O jornal paga muito pouco por uma tira, então fica difícil você de fato ter aquela concentração. Tinha uma época que eu gastava horas pensando numa tira, agora em 15 minutos você tem de resolver a tira, pra compensar, pra você não ir à falência absoluta e completa. Todos os cartunistas são obrigados a ir pra um Lado B; o Adão, por exemplo, está pintando telas e vendendo na internet. Eu fui pro aúdio-visual, estou escrevendo muito roteiro, fiz duas séries no GNT, estou envolvido em vários outros projetos. Tem um longa que eu adaptei, o Mulheres Alteradas, que a O2 filmes comprou os direitos da Maitena e vai rodar em maio com a Deborah Seco, Mônica Iozzi, Alessandra Negrini e a Maria Casadeval. Desenvolver série é uma coisa muito trabalhosa, escrever roteiro te leva a uma exaustão mental completa, aquilo te consome, e aí fazer tira começa a ficar uma coisa muito difícil. Você fala: "vamos reciclar, a coisa é mais por aî”. Aquela tira que você desenhou em 2004, que já faz 12 anos, super legal e que ninguém mais lembra, já virou papel de peixe, pra que que eu vou deixar essa coisa morrer? Ela é bacana, é atual ainda e - no mеu caso - eu tinha personagens e meu traço mudou muito durante os anos, inclusive o figurino dos personagens, como o Chico Bacon, então acabo redesenhando muitas tiras e reaproveitando um material que está lá. É uma reciclagem mesmo; às vezes você não tem tempo pra nada e publica, mas você sempre tem que mandar alguma novidade. Eu ando meio em crise com as tiras, mas voltei a desenhar, fiz uma hoje que adorei, que pensei mesmo. É uma coisa que você fica pensando como que eu vou dar sequência para esses trabalhos, se vai dar sequência, às vezes eu penso em começar escrever pro jornal, não sei, ando pensando muito que caminho que vou dar pra minha tira pra não entrar nessa de passar a republicar material que já foi.

Eu nunca tive reclamação, já reciclei muito várias coisas e nunca o jornal veio falar comigo, até o próprio jornal ele não tem essa memória do que foi publicado. Tira a gente esquece, se for me perguntar qual que é a tira que saiu minha ontem eu não lembro, na semana passada então! Sei lá. A gente esquece mesmo, eu acho que o foco está na qualidade mesmo, você reaproveitar uma ideia que você fez há quatro anos atrás, que ninguém mais lembra e é uma coisa legal, é bom voltar. Eu lembro do Angeli, por exemplo, tinha uma época que começou a republicar muito e eu curtia porque era uma coisa que eu não lembrava mais, eu acho que equivale. O Fernando é uma loucura, ele só faz a tira. As tiras passaram a ser publicadas em livro didático, se você abrir qualquer livro de material escolar, tem ali centenas de tiras. A gente tem uma liberdade muito grande aqui no Brasil. Na Folha a gente faz coisas em tira que nenhum lugar do mundo você vai ver, faz um negócio com o personagem, aí depois você cansa daquilo, você vai 
fazer uma coisa completamente diferente, aí você faz aquele outro negócio não tem personagem, não tem nada, aí você se enche daquilo e começa fazer uma outra loucura e está tudo certo, a gente vai mudando mesmo. O Adão fazia a Aline, não tem mais a Aline; eu fazia Os pescoçudos, não tem mais. O único regular mesmo é o Fernando, com o Níquel Náusea tá há 30 anos, 40 anos fazendo aquilo e é genial, sensacional. O Glauco tinha isso, ele sempre repetia a mesma piada, ele tinha esse dom de repetir a mesma piada todos os dias, por décadas e era legal isso!

\section{RDO: era engraçado. Cada vez que eu leio também dou risada.}

CG: tinha dia que "não, aah não, de novo a Dona Marta jogando um tamanco no Geraldão, pelo amor de Deus!'”. Mas de repente você abria e era divertido, sei lá como que ele tinha esse dom de repetição.

RDO: essa questão da liberdade, Caco, é uma coisa própria da Folha? Você tem ideia se em outros veículos tem mais ingerência? Ou isso é uma coisa da cultura do Brasil na relação do jornal com os autores. Olha o espaço é de vocês, vocês publicam aí e vocês fazem o que vocês quiserem. É meio assim?

CG: é meio assim, acho que no meu caso, sei lá, estou há muitos anos. O Adão também, tem uma moçada ali que a gente já entende o jornal, a gente meio que faz parte daquilo, então não tem muito uma orientação do jornal. Há muitos anos atrás eu lembro que teve um e-mail falando: "olha, o pessoal tá reclamando que tá querendo coisas mais seriais, coisas com personagem”. É uma coisa dos leitores, alguns pedidos, mas temos total liberdade pra desenvolver o que quiser ali, mas temos um filtro, a gente já entende o jornal. Então, o Adão, por exemplo, vai olhar o material dele que tá na web, ele faz um monte de pau, de bunda, de cu que não entra na tirinha porque ele sabe que ali é um espaço. Eu não encaro isso como uma forma de censura, a gente tem uma responsabilidade, sabe que tem muita criança que abre a página de tiras pra ler, a gente mesmo tem o nosso próprio filtro.

RDO: é uma contingência do meio, digamos assim. Acho que no meio digital você é mais livre, já no jornal não. Agora, hoje em dia o Geraldão com aquele pingulim de fora, 5 pingulins de fora balançando seria uma coisa impensável pros dias de hoje. Quando estou analisando as tirinhas e vejo às vezes o Geraldão e as coisas que saiam publicadas, falo, "gente, o mundo encaretou de mais". Eu não consigo imaginar isso na página da Ilustrada, hoje em dia. 
CG: é, o mundo deu uma encaretada forte e a gente tá vivendo essa fase mesmo, de uma espécie de polícia de ideias ideológicas, pessoas que ficam muito irritadas, ódio, né? Uma coisa assim que é um saco.

RDO: antes de passar pra questão da rivalidade, continuando um pouco nessa linha, você diz que hoje em dia tá muito complicado de se viver publicando tirinha. Tem a ver com esse momento de crise do jornal em papel, do meio físico do jornal. Eu queria saber se você pode comentar um pouquinho isso, os jornais estão deixando de publicar tirinhas no Brasil, é isso? Por isso você disse: "antes a gente republicava em vários veículos, não tem mais isso". Por quê? Por que estão deixando de publicar?

CG: estão deixando de publicar, tem jornais fechando, jornais que tão diminuindo, não tem muito como brigar com isso, é meio um caminho sem volta. A gente vai pro digital mesmo, eu não assino mais o impresso, vejo tudo no digital e, de fato, receber aquele calhamaço de papel todas as manhãs na sua casa não faz mais sentido. Essa queima de árvores, de desmatamento, pensa que aquilo você lê e meia hora depois vai pro lixo. Já o livro continua, acho que tem coisas que continuam no papel, o ser humano gosta do papel, de ler coisas, mas essa questão do jornal da notícia, da coisa mais instantânea vai pro digital. Isso pra mim não é um problema. Pra mim eu faço minha tira, o que importa é ela, é o conteúdo, pra onde ela vai, se ela vai pra internet, se ela vai pro impresso, eu não tô muito preocupado com isso não. Na verdade tô armando uma coisa que eu não faço há muitos anos: é uma coletânea grande do meu trabalho pela Companhia das Letras. Vai ser um livrão, isso é uma curtição de fato, acho mais legal ter um livro de quadrinhos mesmo. Porque quadrinhos começou com a gente pegando os livros, os gibis, os fanzines. É uma relação com o impresso muito grande, assim como tinha o jornal também e chega uma hora que deixa de ser, então se minha tira tá na internet e as pessoas tão vendo, e curtindo pra mim tá ótimo, não faço essa questão de ter no impresso ou qualquer tipo de romantismo, ao contrário, acho que as redações e os jornais, quanto mais rápido entrarem nessa transição melhor, porque se não começa a virar uma estrutura insustentável. Você tem um prédio enorme com gráficas máquinas gigantescas, isso era uma coisa que fazia sentido no passado, quando de fato você imprimia ali 500 mil, 1 milhão, milhões e isso ia pras ruas e todo mundo tava interessado. É insustentável, é um custo que não dá mais, as pessoas recebem um impresso e falam: "ah, isso aqui é um jornal com as notícias de ontem”. Perdeu quase toda a função ali, você vai pra internet você tem a notícia atualizada, então de fato eu acho que insistir no impresso é uma espécie de erro, não vejo muita saída pra isso. Tenho amigos jornalistas que falam 
ainda, como o meu primo Ricardo Galhardo, do Estadão, que diz que a coisa mais legal, no final do dia, e ver o prédio vibrando com as prensas ali e aquele 'vuuurr...' Eu falo assim: "Ricardo, isso já era cara, é um romantismo de uma outra época, isso não faz mais sentido". Com um jornal digital você tem que ocupar um andar de um prédio e tocar a coisa ali, ter uma boa equipe, então eu penso muito dessa forma que a gente precisa, na verdade, ser muito rápido e entrar de cabeça nessa transição e não tentar resistir a ela. Você não vai encontrar assinantes da Folha de S. Paulo abaixo dos 40, há pouco tempo atrás era abaixo dos 30, agora eu tô imaginando abaixo dos 40, o impresso. É uma coisa da nossa geração, a gente sempre curtiu...

RDO: sim, eu não tenho a menor dúvida, é isso que eu falei, concordo com você inclusive na questão da pegada ecológica, o custo que isso tem pro meio ambiente, é verdade. Mas eu tenho mesmo essa nostalgia, porque é uma interação com o meio, e no meu caso é interagir com outros meios e construir outro sentido.

CG: é, eu não sei, por exemplo, eu era um cara que na minha formação, nos anos 80 eu tava na faculdade, a aula era eu ir pra banca, comprar o Chiclete com Banana e ir no bar, então esses gibis, pra mim foi uma coisa muito importante, na minha vida. Agora, eu que era um cara que consumia revista e hoje eu não gasto 1 centavo numa banca de jornal com revista há muito tempo. Todo o conteúdo que eu me alimento hoje, ele tá todo na web. Agora, é isso que eu tô te falando, eu vou publicar essa coletânea, você curte por exemplo o Angeli, você vai ali na livraria e compra uma puta edição do Bob Cuspe da Companhia das Letras num papel ótimo, uma edição linda, então eu acho que essa curtição do papel continua por essa via, sabe?

RDO: realmente é muito diferente, a coletânea entra num outro caminho, ela tem um outro status, já entra dentro do mercado de livros, envolve uma edição, é uma outra pegada realmente. Agora gostaria que você falasse sobre a questão da rivalidade, que nas tirinhas da Argentina, eles tiram sarro com a gente, e aqui nas tiras não aparece, só aparece nas charges ou no caderno especial da Folha, não é na Ilustrada. Isso me chamou a atenção, por isso que eu falei assim, é alguma coisa de valor individual? Antes eram você e o Glauco que publicavam, praticamente. Só que em 2014, que é um contexto muito diferente pelas particularidades do que foi a Copa em 2014, tem muito mais tiras diárias sobre futebol do que em todos anos anteriores. Tem ano inclusive que tem uma só. $E$ me chamou atenção isso porque é um lugar comum, Copa, Brasil, Argentina, é meio que algo de se esperar de fazer graça com isso. 
CG: eu acho que talvez essa falta de material deve ter algumas razões, o último jogo de Copa do mundo entre Brasil e Argentina foi na Copa de 90. Desde então não teve cruzamento entre Brasil e Argentina na Copa do Mundo, então não tínhamos essa oportunidade de desenhar essas charges falando dessa rixa, e a gente tá sempre ganhando da Argentina. No futebol - é óbvio - essa rivalidade é super forte, no meu caso acho que já brinquei em alguma coisa com isso. Eu fui ano passado ou retrasado pra Quito, acho que ano passado, eu fui num encontro lá de cartunistas, eles estavam tendo muito problema com o Rafael Correa, que estava multando os cartunistas, eles estão com um problema sério de liberdade de expressão na imprensa. Aí tinha cartunista da Argentina, do Equador, do Chile, do México, da Nicarágua e era uma coisa que eu vi, todos chegavam se encontravam e de imediato falavam sobre as bandas que estavam ouvindo, todo mundo conhecia as mesmas bandas, todo mundo conhecia os mesmos escritores, os mesmo desenhistas, e eu brasileiro parecia um ignorante, porque a gente aqui no Brasil, a gente tem um distanciamento tão grande dos nossos irmãos latinos que são tão legais, a moçada do Equador, a moçada da Argentina. Todos eles, a gente é o mesmo povo da América Latina, a gente tem essa diferença da língua, o português, mas assim em termos de cultura, de consumo da cultura eles tão totalmente alinhados e a gente tá fora, a gente tá fechado no nosso mundo aqui do Brasil e olhando pros Estados Unidos e a gente não sabe quase nada, muito pouco, esse intercambio nosso é muito precário, então no meu discurso eu prefiro não dar vazão pra essa rixa, eu prefiro falar de outra forma, no futebol é claro que vira piada, mas eu pessoalmente, acho que a gente tinha que adotar um discurso totalmente diferente da rixa.

RDO: é alguma coisa que também me ocorreu, pensei em valores pessoais e de uma nova geração. Por outro lado, nas tiras de lá, Caco, mesmo que a gente não tenha se enfrentado, quando era jogo do Brasil, tinha comentários sobre o torcer contra, torcer pro outro time e não pro Brasil. E no caso da Nelly, publicada no Clarín, que atira pra todo lado, então é o escárnio total, era contra o Pelé, contra o Neymar, ninguém escapava, mas também tinha uma autocrítica grande, a Nelly, a metralhadora dela aponta para todos os lados.

CG: é..., você está falando assim do meu trabalho e do Glauco, eu acho que devem ter publicações mais especializadas em futebol como o Lance que deve ter um cartunista ali que só faz charge de futebol e esse cara deve explorar muito esse ponto. Tanto eu quanto o Glauco, a gente fez trabalho relacionados a futebol como uma coisa muito pontual na carreira, mais explorando o lado de torcedor mesmo, ver o que as pessoas tão sentindo 
no dia do jogo, como que isso tá me mexendo com as pessoas, do que o jogo em si, essa paixão, porque a gente não é torcedores, o cara que só pensa em futebol, a gente tá longe disso, então acho que a gente não chegou a desenvolver um discurso, uma narrativa, criar um universo sobre essa temática, foi uma coisa muito pontual mesmo. 


\section{ANEXOS}

\section{Anexo 1}

Letra da canção Yo no quiero volverme tan loco de autoria de Charly García citada na página 196.

Yo no quiero volverme tan loco

yo no quiero vestirme de rojo

yo no quiero morir en el mundo hoy.

Yo no quiero ya verte tan triste

yo no quiero saber lo que hiciste

yo no quiero esta pena en mi corazón.

Escucho un bit de un tambor entre la desolación

de una radio en una calle desierta

están las puertas cerradas y las ventanas también

no será que nuestra gente está muerta?

Presiento el fin de un amor en la era del color

la televisión está en las vidrieras

toda esa gente parada que tiene grasa en la piel

no se entera ni que el mundo da vueltas.

Yo no quiero meterme en problemas

yo no quiero asuntos que queman

yo tan sólo les digo que es un bajón.

Yo no quiero sembrar la anarquía

yo no quiero vivir como digan

tengo algo que darte en mi corazón.

Escucho un tango y un rock y presiento que soy yo

y quisiera ver al mundo de fiesta.

Veo tantas chicas castradas y tantos tontos que al fin

yo no sé si vivir tanto les cuesta.

Yo quiero ver muchos más delirantes por ahí bailando en una calle cualquiera

en Buenos Aires se ve que ya no hay tiempo de más

la alegría no es sólo brasilera, no mi amor.

Yo no quiero vivir paranoico

yo no quiero ver chicos con odio

yo no quiero sentir esta depresión

voy buscando el placer de estar vivo

no me importa si soy un bandido

voy pateando basura en el callejón

Yo no quiero volverme tan loco

yo no quiero vestirme de rojo

yo no quiero morir en el mundo hoy.

Yo no quiero ya verte tan triste

yo no quiero saber lo que hiciste

yo no quiero esta pena en mi corazón.

Yo no quiero sentir esta pena en mi corazón.

Fonte: 〈http://rock.com.ar/artistas/177/letras/979>. Acesso em 05 de junho de 2017. 


\section{Anexo 2}

Cartum de autoria de Henfil publicada no jornal $O$ Pasquim, durante a realização da Copa do Mundo de 1970.

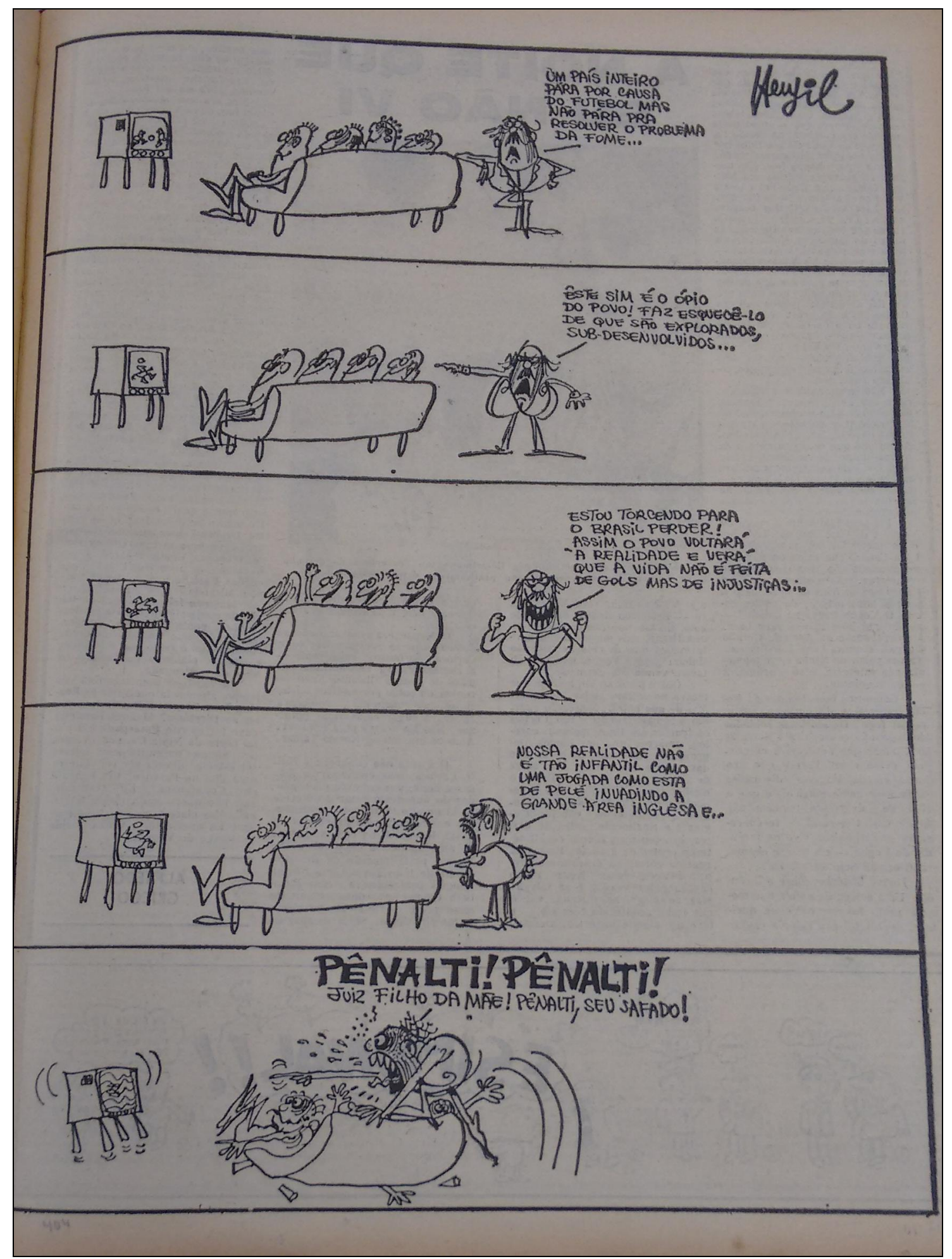

“A Copa segundo Henfil” in O Pasquim, edição número 51, de 11 a 17 de junho de 1970, p. 11. 


\section{Anexo 3}

Produções gráficas publicadas nos jornais Clarín e La Nación após o vice-campeonato argentino na Copa do Mundo de 2014 que citam o personagem Clemente de Caloi.

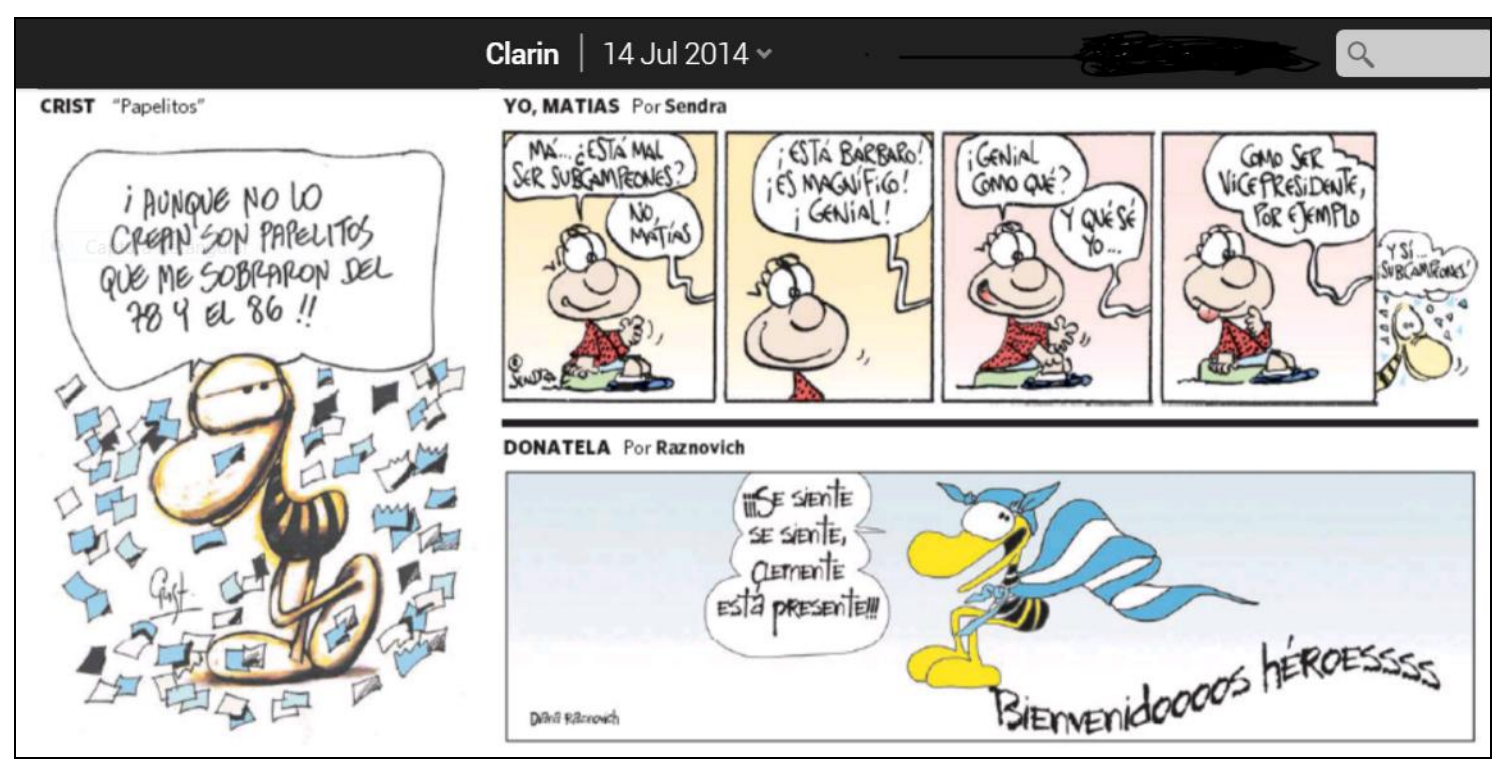

Fonte: Clarín, 14/07/2014.

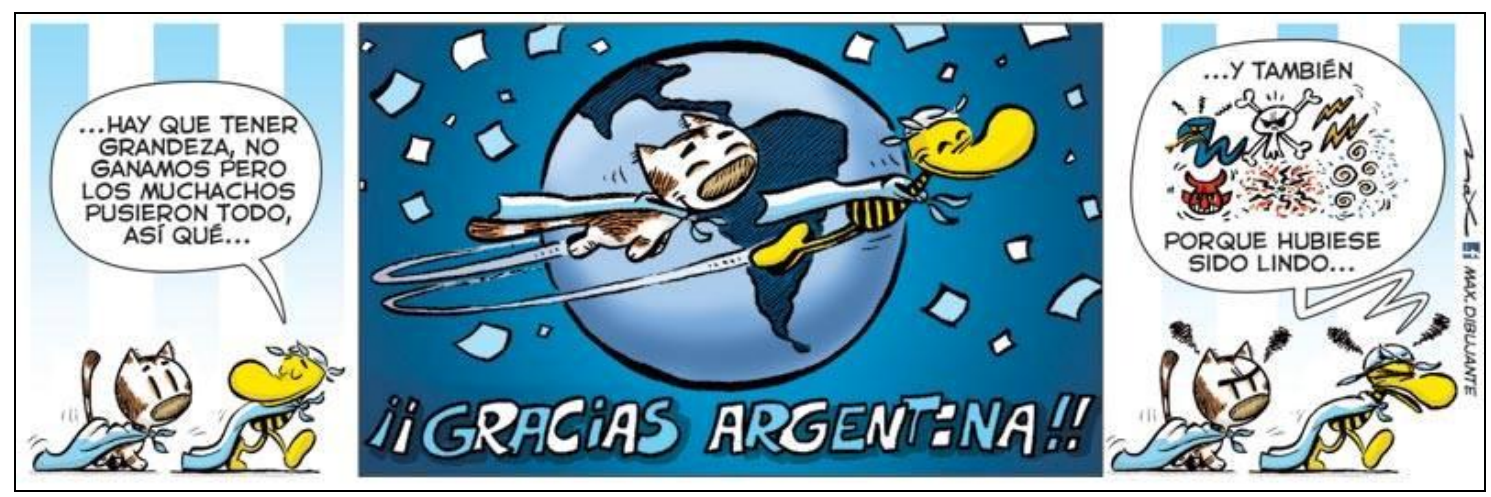

Fonte: La Nación - 14/07/2014. 